\title{
Hospital at home early discharge (Review)
}

Shepperd S, Doll H, Broad J, Gladman J, Iliffe S, Langhorne P, Richards S, Martin F, Harris R

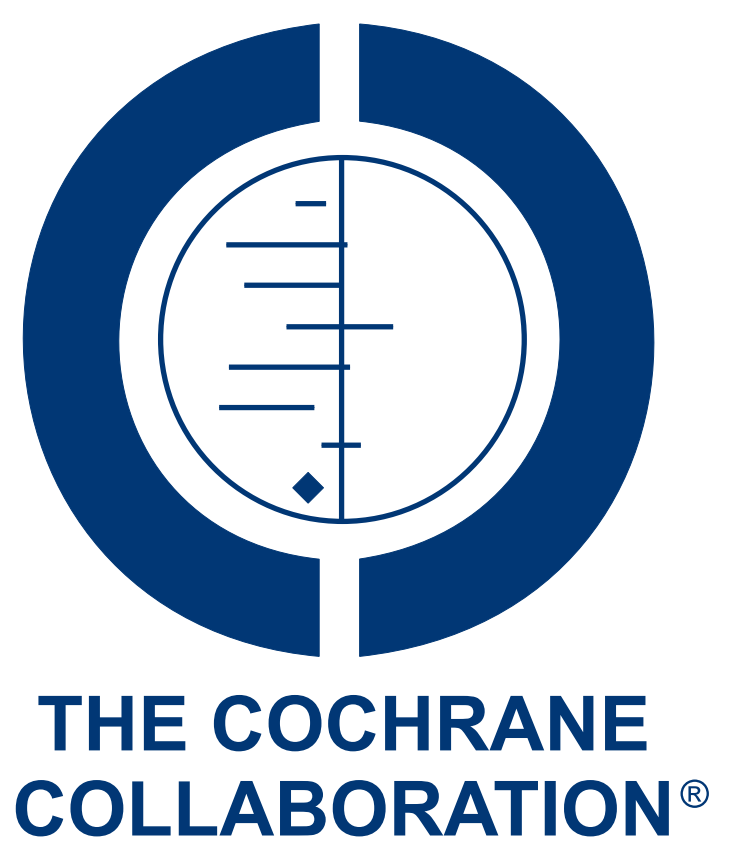

This is a reprint of a Cochrane review, prepared and maintained by The Cochrane Collaboration and published in The Cochrane Library 2011, Issue 8

http://www.thecochranelibrary.com

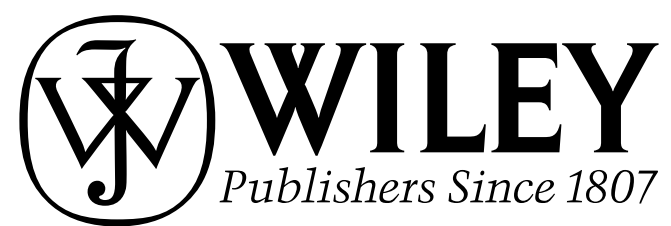


TABLE OF CONTENTS

HEADER . . . . . . . . . . . . . . . . . . . . . . . . . . . . . . . . . . . . . . . 1

ABSTRACT . . . . . . . . . . . . . . . . . . . . . . . . . . . . . . . . . . . . . . . . . . . . 1

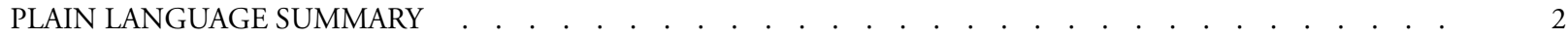

BACKGROUND . . . . . . . . . . . . . . . . . . . . . . . . . . . . . . . . . . . . . 2

OBJECTIVES . . . . . . . . . . . . . . . . . . . . . . . . . . . . . . . . . . . . . . . . . . . .

METHODS . . . . . . . . . . . . . . . . . . . . . . . . . . . . . . . . . . . . . . 3

RESULTS . . . . . . . . . . . . . . . . . . . . . . . . . . . . . . . . . . . . . . . 5

DISCUSSION . . . . . . . . . . . . . . . . . . . . . . . . . . . . . . . . . . 11

AUTHORS' CONCLUSIONS . . . . . . . . . . . . . . . . . . . . . . . . . . . . . . . . . . . . . . . . . 12

ACKNOWLEDGEMENTS . . . . . . . . . . . . . . . . . . . . . . . . . . . . . . . . . . . . . . . . . . 13

REFERENCES . . . . . . . . . . . . . . . . . . . . . . . . . . . . . . . . . . . . . 13

CHARACTERISTICS OF STUDIES . . . . . . . . . . . . . . . . . . . . . . . . . . . . . . . . . 16

DATA AND ANALYSES . . . . . . . . . . . . . . . . . . . . . . . . . . . . . . . . . . . . . . . . . . 40

Analysis 1.2. Comparison 1 Hospital at home versus in-patient care, Outcome 2 Mortality at 3 months - older people with a mix of conditions. . . . . . . . . . . . . . . . . . . . . . . . . . . . . . . . . . . . 96

Analysis 1.3. Comparison 1 Hospital at home versus in-patient care, Outcome 3 Mortality at 6 months - older people with a medical condition requiring geriatric rehabilitation. . . . . . . . . . . . . . . . . . . . . 96

Analysis 1.4. Comparison 1 Hospital at home versus in-patient care, Outcome 4 Mortality at 3 months - patients recovering from a stroke. . . . . . . . . . . . . . . . . . . . . . . . . . . . . . . . . . . 9 97

Analysis 1.5. Comparison 1 Hospital at home versus in-patient care, Outcome 5 Mortality at 6 months - patients recovering from a stroke. . . . . . . . . . . . . . . . . . . . . . . . . . . . . . . . . . . 98

Analysis 1.6. Comparison 1 Hospital at home versus in-patient care, Outcome 6 Mortality at 1 year - patients recovering from a stroke. . . . . . . . . . . . . . . . . . . . . . . . . . . . . . . . . . .

Analysis 1.7. Comparison 1 Hospital at home versus in-patient care, Outcome 7 Mortality - chronic obstructive airways disease.

Analysis 1.8. Comparison 1 Hospital at home versus in-patient care, Outcome 8 Readmission to hospital at 3 months older people with a mix of conditions.

Analysis 1.9. Comparison 1 Hospital at home versus in-patient care, Outcome 9 Readmissions at 3 months - those recovering from a stroke. . . . . . . . . . . . . . . . . . . . . . . . . . . . . . .

Analysis 1.10. Comparison 1 Hospital at home versus in-patient care, Outcome 10 Readmissions at 6 months - those recovering from a stroke.

Analysis 1.11. Comparison 1 Hospital at home versus in-patient care, Outcome 11 Readmission at 1 year for those recovering from a stroke. . . . . . . . . . . . . . . . . . . . . . . . . . . . . . . 102

Analysis 1.12. Comparison 1 Hospital at home versus in-patient care, Outcome 12 Readmission for those with COPD. 103

Analysis 1.13. Comparison 1 Hospital at home versus in-patient care, Outcome 13 Functional ability at 3 months - older people with a mix of conditions. . . . . . . . . . . . . . . . . . . . . . . . . . . . . . . . . . .

Analysis 1.14. Comparison 1 Hospital at home versus in-patient care, Outcome 14 Residential care at 1 year follow up (Donald 6 months) - older patients with a mix of conditions. . . . . . . . . . . . . . . . . . 104

Analysis 1.15. Comparison 1 Hospital at home versus in-patient care, Outcome 15 Residential care at 6 months follow up (Rodgers 3 month data) - recovering from a stroke. . . . . . . . . . . . . . . . . . . . . . 105

Analysis 1.16. Comparison 1 Hospital at home versus in-patient care, Outcome 16 Hospital length of stay - older people with a mix of conditions. . . . . . . . . . . . . . . . . . . . . . . . . . . . . . . 105

Analysis 1.17. Comparison 1 Hospital at home versus in-patient care, Outcome 17 Hospital length of stay - those recovering from a stroke. . . . . . . . . . . . . . . . . . . . . . . . . . . . . . . . . . 106

Analysis 1.18. Comparison 1 Hospital at home versus in-patient care, Outcome 18 Hospital length of stay - patients with chronic obstructive pulmonary disease. . . . . . . . . . . . . . . . . . . . . . . . . . 106

Analysis 1.19. Comparison 1 Hospital at home versus in-patient care, Outcome 19 Total length of stay - older people with a mix of mainly medical conditions. . . . . . . . . . . . . . . . . . . . . . . . . . . . . . . . . . . . . $\quad 107$

Analysis 1.21. Comparison 1 Hospital at home versus in-patient care, Outcome 21 Hospital length of stay - older people recovering from surgery. 
Analysis 1.22. Comparison 1 Hospital at home versus in-patient care, Outcome 22 Total length of stay - older people having elective surgery. . . . . . . . . . . . . . . . . . . . . . . . . . . . . . . .

Analysis 1.23. Comparison 1 Hospital at home versus in-patient care, Outcome 23 Readmission to hospital - surgery.

Analysis 2.1. Comparison 2 IPD data analysis, Outcome 1 IPD generic inverse variance early discharge elderly medical mortality at 3 months. . . . . . . . . . . . . . . . . . . . . . . . . . . . . . . .

Analysis 2.2. Comparison 2 IPD data analysis, Outcome 2 IPD generic inverse variance early discharge readmission at 3 months. . . . . . . . . . . . . . . . . . . . . . . . . . . . . . . . . . . . .

Analysis 2.3. Comparison 2 IPD data analysis, Outcome 3 IPD stroke mortality at 3 to 6 months - Manchester, Anderson, Cunliffe, Shepperd 3 months. . . . . . . . . . . . . . . . . . . . . . . . . . . . . . . 126

Analysis 2.4. Comparison 2 IPD data analysis, Outcome 4 Stroke Barthel at 3 months. . . . . . . . . . . . . . 126

Analysis 2.5. Comparison 2 IPD data analysis, Outcome 5 Stroke Barthel at 6 months. . . . . . . . . . . . . . . . 127

Analysis 2.6. Comparison 2 IPD data analysis, Outcome 6 Sensitivity analysis in favour of HAH. . . . . . . . . . . . 128

Analysis 2.7. Comparison 2 IPD data analysis, Outcome 7 Sensitivity analysis in favour of hospital. . . . . . . . . . 129

Analysis 2.8. Comparison 2 IPD data analysis, Outcome 8 Sensitivity analysis removing readmissions in the first 14 days. . . . . . . . . . . . . . . . . . . . . . . . . . . . . . . . .

Analysis 2.9. Comparison 2 IPD data analysis, Outcome 9 Readmission stroke. . . . . . . . . . . . . . . . . . .

Analysis 3.1. Comparison 3 IPD adjusted for age only, Outcome 1 IPD generic inverse variance early discharge elderly medical mortality at 3 months.

Analysis 3.2. Comparison 3 IPD adjusted for age only, Outcome 2 IPD mortality at 3 to 6 months (Manchester, Anderson $\&$ Shepperd at 3 months).

Analysis 3.3. Comparison 3 IPD adjusted for age only, Outcome 3 IPD generic inverse variance early discharge readmission at 3 months.

Analysis 3.4. Comparison 3 IPD adjusted for age only, Outcome 4 Stroke Barthel at 3 months. . . . . . . . . . . . 132

Analysis 3.5. Comparison 3 IPD adjusted for age only, Outcome 5 Stroke Barthel at 6 monhts. . . . . . . . . . . $\quad 132$

Analysis 3.6. Comparison 3 IPD adjusted for age only, Outcome 6 Sensitivity analysis mortality in favour of HAH. . 133

Analysis 3.7. Comparison 3 IPD adjusted for age only, Outcome 7 Sensitivity analysis mortality in favour of hospital.

Analysis 4.1. Comparison 4 IPD adjusted for age and sex, Outcome 1 IPD generic inverse variance early discharge elderly medical mortality at 3 months. . . . . . . . . . . . . . . . . . . . . . . . . . . . .

Analysis 4.2. Comparison 4 IPD adjusted for age and sex, Outcome 2 IPD stroke mortality at 3 to 6 months - Manchester, Anderson, Cunliffe \& Shepperd 3 months.

Analysis 4.3. Comparison 4 IPD adjusted for age and sex, Outcome 3 IPD generic inverse variance readmission elderly patients with a mix of conditions. 32

Analysis 4.4. Comparison 4 IPD adjusted for age and sex, Outcome 4 Stroke Barthel at 3 months.

Analysis 4.5. Comparison 4 IPD adjusted for age and sex, Outcome 5 Stroke Barthel at 6 months.

Analysis 4.6. Comparison 4 IPD adjusted for age and sex, Outcome 6 Sensitivity analysis mortality elderly patients with a mix of conditions in favour of $\mathrm{HAH}$. . . . . . . . . . . . . . . . . . . . . . . . . . . . . . . . . .

Analysis 4.7. Comparison 4 IPD adjusted for age and sex, Outcome 7 Sensitivity analysis mortality elderly patient with a mix of conditions in favour of hospital.

Analysis 4.8. Comparison 4 IPD adjusted for age and sex, Outcome 8 Sensitivity analysis changing follow-up time for Donnelly trial in favour of HAH.

Analysis 4.9. Comparison 4 IPD adjusted for age and sex, Outcome 9 Sensitivity analysis changing follow-up time for Donnelly (stroke) in favour of hospital.

Analysis 4.10. Comparison 4 IPD adjusted for age and sex, Outcome 10 Sensitivity analysis removing readmissions for elderly with a mix of conditions during first 14 days adjusted for age and sex.

Analysis 4.11. Comparison 4 IPD adjusted for age and sex, Outcome 11 Readmission - recovering from a stroke. . .

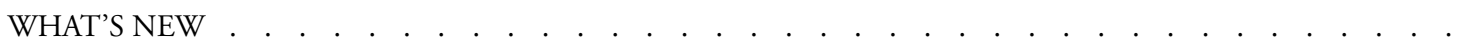

HISTORY . . . . . . . . . . . . . . . . . . . . . . . . . . . . . . . . . . . . . . . . . . . . . . . .

CONTRIBUTIONS OF AUTHORS . . . . . . . . . . . . . . . . . . . . . . . . . . . . . . . . . . . . . . . . .

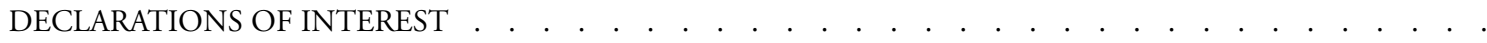

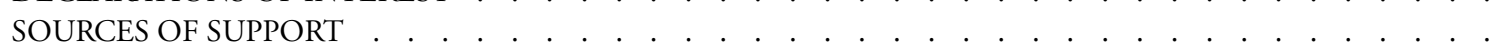




\section{[Intervention Review]}

\section{Hospital at home early discharge}

Sasha Shepperd ${ }^{1}$, Helen Doll ${ }^{1}$, Joanna Broad ${ }^{2}$, John Gladman $^{3}$, Steve Iliffe ${ }^{4}$, Peter Langhorne ${ }^{5}$, Suzanne Richards ${ }^{6}$, Finbarr Martin ${ }^{7}$, Roger Harris ${ }^{8}$

${ }^{1}$ Department of Public Health, University of Oxford, Oxford, UK. ${ }^{2}$ School of Population Health, University of Auckland, Auckland, New Zealand. ${ }^{3}$ Rehabilitation and Ageing, Community Health Sciences, Queen Medical Centre, University of Nottingham, Nottingham, UK. ${ }^{4}$ Research Department of Primary Care and Population Health, University College London, London, UK. ${ }^{5}$ Academic Section of Geriatric Medicine, University of Glasgow, Glasgow, UK. ' Peninsula Medical School, Universities of Exeter and Plymouth, Exeter, UK. ${ }^{7}$ Guys and St Thomas' NHS Foundation Trust and KCL Institute of Gerontology, London, UK. ${ }^{8}$ Older Peoples Health, Auckland City Hospital, Grafton, New Zealand

Contact address: Sasha Shepperd, Department of Public Health, University of Oxford, Rosemary Rue Building, Headington, Oxford, Oxfordshire, OX3 7LF, UK. sasha.shepperd@dphpc.ox.ac.uk.

Editorial group: Cochrane Effective Practice and Organisation of Care Group.

Publication status and date: Edited (no change to conclusions), published in Issue 8, 2011.

Review content assessed as up-to-date: 23 July 2008.

Citation: Shepperd S, Doll H, Broad J, Gladman J, Iliffe S, Langhorne P, Richards S, Martin F, Harris R. Hospital at home early discharge. Cochrane Database of Systematic Reviews 2009, Issue 1. Art. No.: CD000356. DOI: 10.1002/14651858.CD000356.pub3.

Copyright (c) 2011 The Cochrane Collaboration. Published by John Wiley \& Sons, Ltd.

\section{A B S T R A C T}

\section{Background}

'Early discharge hospital at home' is a service that provides active treatment by health care professionals in the patient's home for a condition that otherwise would require acute hospital in-patient care. If hospital at home were not available then the patient would remain in an acute hospital ward.

\section{Objectives}

To determine, in the context of a systematic review and meta-analysis, the effectiveness and cost of managing patients with early discharge hospital at home compared with in-patient hospital care.

\section{Search methods}

We searched the Cochrane Effective Practice and Organisation of Care (EPOC) Group Register, MEDLINE (1950 to 2008), EMBASE (1980 to 2008), CINAHL (1982 to 2008) and EconLit through to January 2008. We checked the reference lists of articles identified for potentially relevant articles.

\section{Selection criteria}

Randomised controlled trials recruiting patients aged 18 years and over. Studies comparing early discharge hospital at home with acute hospital in-patient care. Evaluations of obstetric, paediatric and mental health hospital at home schemes are excluded from this review.

\section{Data collection and analysis}

Two authors independently extracted data and assessed study quality. Our statistical analyses were done on an intention-to-treat basis. We requested individual patient data (IPD) from trialists, and relied on published data when we did not receive trial data sets or the IPD did not include the relevant outcomes. For the IPD meta-analysis, where at least one event was reported in both study groups in a trial, Cox regression models were used to calculate the log hazard ratio and its standard error for mortality and readmission separately for each data set. The calculated log hazard ratios were combined using fixed-effect inverse variance meta-analysis. 


\section{Main results}

Twenty-six trials were included in this review [n = 3967]; 21 were eligible for the IPD meta-analysis and 13 of the 21 trials contributed data [1899/2872; 66\%]. For patients recovering from a stroke and elderly patients with a mix of conditions there was insufficient evidence of a difference in mortality between groups (adjusted HR 0.79, 95\% CI 0.32 to 1.91; N = 494; and adjusted HR 1.06, 95\% CI 0.69 to $1.61 ; \mathrm{N}=978$ ). Readmission rates were significantly increased for elderly patients with a mix of conditions allocated to hospital at home (adjusted HR 1.57; 95\% CI 1.10 to 2.24; $\mathrm{N}=705$ ). For patients recovering from a stroke and elderly patients with a mix of conditions respectively, significantly fewer people allocated to hospital at home were in residential care at follow-up (RR 0.63; 95\% CI 0.40 to $0.98 ; \mathrm{N}=4$ trials; RR $0.69,95 \%$ CI 0.48 to $0.99 ; \mathrm{N}=3$ trials). Patients reported increased satisfaction with early discharge hospital at home. There was insufficient evidence of a difference for readmission between groups in trials recruiting patients recovering from surgery. Evidence on cost savings was mixed.

\section{Authors' conclusions}

Despite increasing interest in the potential of early discharge hospital at home services as a cheaper alternative to in-patient care, this review provides insufficient objective evidence of economic benefit or improved health outcomes.

\section{PLAIN LANGUAGE SUMMARY}

\section{Services for patients discharged home early}

There continues to be, in some countries, more demand for acute care hospital beds than there are beds. One way to free up beds to make room for other people being admitted is to discharge patients home early. But the patients who are discharged still need acute care. Therefore, special home services have been developed. These services are usually provided by a team of health care professionals, such as doctors, nurses and physiotherapists. The team visits the home of people who have been discharged early to provide them with acute hospital care in their homes.

A review of the effect of services for patients discharged home early was conducted. After searching for all relevant studies, 26 studies were identified. The studies looked at the effect of these services in patients with different types of conditions: patients who had a stroke, patients who had surgery, and elderly patients who had different types of conditions.

There was insufficient evidence that providing services to people at home after being discharged home early may increase the risk of death or readmission; or adversely effect quality of life or the completion of daily activities (such as dressing or daily chores). Patients who had a stroke or elderly patients may have less risk of being admitted to residential care if they are discharged home early with hospital at home services.

Patients may also be more satisfied with their care at home, and at the same time their carers, in most cases, did not report additional burden. However, there is little evidence of cost savings to the health care system of discharging patients home early to hospital at home care.

\section{B A C K G R O U N D}

The concept of hospital at home originated with Hospitalisation à Domicile in France in 1961 and has been implemented in a number of other countries, including the United States, the Netherlands and Australia (Bosna 1993; Leff 2005; Montalto 1998). In its original form, Hospitalisation à Domicile was intended to provide care, including specialist care, at home for certain groups of patients who traditionally received care and treatment in hospital but who opted, with the support of their families, to be cared for in their home (Clarke 1984; Morris 1983).

Today, hospital at home schemes vary in their philosophy and focus of care, and may be community based or hospital resourced. The community based schemes build on existing community resources, which may include home health agencies; the hospital resourced schemes provide an outreach service with hospital staff making domiciliary visits. In the UK, hospital at home usually con- 
centrates on providing personal, nurse-led care rather than technical services, building on the existing structure of primary care. The exception is home intravenous services (Matthews 2007). In other countries, such as the United States and Australia, hospital based outreach services tend to dominate (Leff 2005) and in a few, integration of specialist hospital services and primary care is more common.

Patients treated by hospital at home may avoid admission to an acute hospital ward after assessment in the community by their primary care physician or in the emergency department. Alternatively patients may be discharged early from hospital to receive hospital at home care. This review is part of the update of the hospital at home review published in 2005 (Shepperd 2005). The original review is now split into three reviews with this one focusing on early discharge hospital at home. In a parallel review we report the results of an individual patient data meta-analysis of admission avoidance trials (Shepperd 2008); a protocol is currently being developed for a systematic review of terminal care hospital at home. The types of services provided by early discharge hospital at home are designed to care for patients discharged early from hospital and provide coordinated rehabilitation with specialist care (Hollingworth 1993; O'Cathain 1994; Pryor 1989); the aim is to provide a service that relieves the pressure on acute hospital beds.

It is not known if patients admitted to early discharge hospital at home have better, equivalent or worse health outcomes compared with patients receiving in-patient hospital care, nor if the provision of early discharge hospital at home results in a reduction or increase in costs to the health service.

\section{O B JE C T IVES}

To determine, in the context of a systematic review and metaanalysis, the effectiveness and cost of managing patients with early discharge hospital at home compared with in-patient hospital care.

We address the following questions:

1. Do patients treated by early discharge hospital at home services have different health outcomes, in terms of mortality, functional status and quality of life, than patients who remain in hospital for their episode of care?

2. Do readmission rates, or transfers to hospital, differ for patients treated in early discharge hospital at home compared with patients who remain in hospital for their episode of care?

3. Does patient satisfaction or carer satisfaction differ between early discharge hospital at home care and in-patient care?

4. Do the costs to the health service alter as a result of setting up and providing early discharge hospital at home care?
5. Does the workload of doctors working in primary care change as a result of setting up and delivering care to patients admitted to early discharge hospital at home?

\section{METHODS}

\section{Criteria for considering studies for this review}

\section{Types of studies}

Randomised controlled trials.

\section{Types of participants}

The review includes evaluations of early discharge hospital at home schemes that include patients aged 18 years and over. Patients with long-term care needs are not included unless they required admission to hospital for an acute episode of care. We defined older patients as those older than 65 . We excluded evaluations of obstetric, paediatric and mental health hospital at home schemes from the review since our preliminary literature searches suggested that separate reviews would be justified for each of these groups due to the different types of patient group and volume of literature (Parker 2002; Shepperd 2007).

\section{Types of interventions}

Studies comparing early discharge hospital at home with acute hospital in-patient care. We used the following definition to determine if studies should be included in the review: hospital at home is a service that provides active treatment by health care professionals in the patient's home for a condition that otherwise would require acute hospital in-patient care, and always for a limited time period. In particular, hospital at home has to offer a specific service to patients in their home requiring health care professionals to take an active part in the patients' care. If hospital at home were not available then the patient would not be discharged early from hospital and would remain on an acute hospital ward. Therefore, the following services are excluded from this review: services providing long term care, services provided in out-patient settings or post discharge from hospital, and self-care by the patient in their home such as self-administration of an intravenous infusion.

\section{Types of outcome measures}

- Mortality

- Readmissions

- General and disease-specific health status

- Functional status

- Psychological well-being 
- Clinical complications

- Patient satisfaction

- Carer satisfaction

- Carer burden

- Staff views (including general practitioners' satisfaction)

- Discharge destination from hospital at home

- Length of stay in hospital and hospital at home

- Cost (this includes the costs to the patient and their family, to general practice, to the hospital and social or voluntary service costs)

\section{Search methods for identification of studies}

See EPOC 2008 for addtional details about search methods. We searched the following databases: the Cochrane Effective Practice and Organisation of Care (EPOC) Group Register, Ovid MEDLINE(R) 1950 to January Week 3 2008, EMBASE 1980 to 2008 Week 11, CINAHL1982 to February Week 52008 and EconLit through to January 2008. Full details of the search terms used are in Appendix 1 at the end of this document. The EPOC register is compiled with searches of the following databases: MEDLINE (from 1966), HealthSTAR (from 1975), EMBASE (from 1980) and CINAHL (from 1982). New records in MEDLINE, HealthSTAR, EMBASE and CINAHL are searched on a regular basis for additional studies. The Cochrane Central Register of Controlled Trials (CENTRAL) database in The Cochrane Library is searched every three months (each issue) for studies relevant to EPOC.

We checked the reference lists of articles identified electronically for evaluations of hospital at home and obtained potentially relevant articles. We sought unpublished studies by contacting providers and researchers who were known to be involved in this field. A list of contacts was developed using the existing literature and following discussion with researchers in the area.

\section{Data collection and analysis}

One author (SS) read all the abstracts in the records retrieved by the electronic searches to identify publications that appeared to be eligible for this review. Two authors (SS and SI) independently read these publications and selected studies for the review according to the pre-specified inclusion criteria. We resolved disagreements by discussion. We assessed the quality of eligible trials using the criteria described by the EPOC Group (see 'METHODS USED IN REVIEWS', 'ASSESSMENT OF METHODOLOGICAL QUALITY' under 'GROUP DETAILS' in The Cochrane Library). Two authors (SS and SI) completed data extraction independently using a checklist developed by EPOC, modified and amended for the purposes of this review (see 'METHODS USED IN REVIEWS' under 'GROUP DETAILS'). We conducted an
IPD meta-analysis in a subgroup of trials evaluating specific outcomes in the more homogeneous populations described below.

\section{Individual patient data (IPD)}

We contacted the investigators of 21 of the included trials (total number of participants $=2872$ ) by email or telephone, inviting them to contribute data to the hospital at home early discharge collaborative review. We had to send up to four reminders; it took up to 22 months to receive the data. Data from one of these trials contributed to the analysis of those with chronic obstructive pulmonary disease, older people with an acute medical condition, and those recovering from a stroke. To avoid triple counting this trial it is only counted once under 'older patients with a medical condition' (Shepperd 1998). As a minimum we requested trialists to send us an identifier for each recruited patient, demographic data, date of recruitment, allocation group, follow-up times, details of the intervention and data (including dates) on mortality and hospital readmission. We also requested additional outcome data on functional ability, quality of life, satisfaction, carer burden, resources used and cost. We did not attempt to obtain IPD for five trials included in this review, though we did include these trials in the review, as they were considered to have recruited participants who differed substantially from the populations in the other trials. Two of these five trials were conducted in 1978 and recruited patients having surgery for conditions no longer requiring a hospital admission (hernia or varicose veins) (Adler 1978; Ruckley 1978); and three of the five trials recruited patients with a condition unique to that trial which prevented the data being pooled (patients recovering from coronary artery bypass grafting, hip fracture or total knee replacement) (Booth 2004; Crotty 2002; Palmer Hill 2000).

\section{Statistical analysis}

Our statistical analyses sought to include all randomised patients and were done on an intention to treat basis. We relied on published data when the IPD did not include the relevant outcomes. When combining outcome data was not possible because of differences in the reporting of outcomes, we presented the data in narrative summary tables. Where possible we grouped the trials by the patients' condition: patients recovering from a stroke, older patients with a mix of conditions (including chronic obstructive pulmonary disease and those recovering from orthopaedic surgery), and trials recruiting patients recovering from surgery.

Using the IPD we calculated hazard ratios for the dichotomous outcomes mortality and readmission, with $95 \%$ confidence intervals for all point estimates, using a fixed effect model. Where at least one event was reported in both study groups in a trial, we used Cox regression models to calculate the log hazard ratio and its standard error for mortality and readmission separately for each data set (where both outcomes were available). We included ran- 
domisation group (early discharge hospital at home versus control), age (above or below the median for each trial) and gender in the models. We combined the calculated log hazard ratios using fixed effect inverse variance meta-analysis (Deeks 1998). The pooled effect is expressed as the hazard ratio for hospital at home compared with usual hospital care where values $<1$ indicate outcomes favouring hospital at home. Heterogeneity was quantified by Cochran's Q (Cochran 1954) and the $\mathrm{I}^{2}$ statistic, the latter quantifying the percentage of the total variation across studies that is due to heterogeneity rather than chance (Higgins 2003); smaller percentages suggest less observed heterogeneity. If there were no events in one group we used the Peto odds ratio method to calculate a $\log$ odds ratio from the sum of the log-rank test 'O-E' statistics from a Kaplan Meier survival analysis. This method does not require corrections for zero cell counts and thus it performs well when events are rare (Deeks 1998). Statistical significance throughout was taken at the two-sided 5\% level $(\mathrm{P}<0.05)$ and data are presented as the estimated effect with $95 \%$ confidence intervals. All analyses were undertaken in SPSS version 14.0 (SPSS 2006) and STATA (STATA 2004), with the meta-analysis being undertaken in Review Manager 4.2 and Review Manager 5.

Comparison between health outcomes was restricted by the different measurement tools used and method of reporting in the included trials. A direct comparison of costs, although planned, was not attempted because the trials used different methods to calculate costs.

\section{Dealing with missing data}

Two of the trial data sets provided event data with the time interval in which the event occurred, but no dates. For one of these data sets (Richards 1998) follow-up was at one and three months, and we only knew if an event had occurred during each time period (i.e.up to one month and from one to three months). For such events we imputed the event date as the midpoint day. Thus, if we knew that death occurred within one month of randomisation we gave the date of death as 15 days from randomisation. If the event occurred between one and three months then we gave the date of death as 61 days from randomisation (midway between one month and three months). For the second trial (Rodgers 1997) the data on death and readmission simply indicated that the event had taken place within six months of randomisation; for these events we imputed an event date as 91 days, the midpoint between randomisation and six months.

Similarly, in another data set where some dates were missing for known events, we gave the missing event a date of 91 days, the midpoint between randomisation and end of follow-up (Anderson 2000; Donnelly 2004).

For one trial 17 cases were withdrawn at three months; we gave a mid point follow-up time of 61 days for three of these cases for whom a date for withdrawal was not available but who did have one month follow-up data (Richards 1998). The other 14 cases had been withdrawn before one month follow-up, and we gave these a mid-point 15 day withdrawal date.

\section{Sensitivity analysis}

We used sensitivity analyses to assess the impact of the increased 'exposure' time to readmission for the hospital at home group compared with the hospital group. We calculated a pooled estimate both including and excluding transfers or readmissions to hospital occurring within the first 14 days, as this was the average duration that hospital patients spent in hospital. For the two studies (Donnelly 2004; Richards 1998) in which missing data were imputed, we undertook sensitivity analyses (assigning best and worse case scenarios to the intervention and comparison group) to assess the likely effect of such imputation.

\section{RES U L T S}

\section{Description of studies}

See: Characteristics of included studies; Characteristics of excluded studies.

We identified 25 published trials, and one unpublished trial, for inclusion in the current update of this review of early discharge hospital at home. Five of these trials were not eligible for the IPD meta-analysis as two trials recruited patients following surgery for hernia or varicose veins (Adler 1978; Ruckley 1978), one trial recruited patients recovering from coronary artery bypass grafting (Booth 2004), one trial patients recovering from a hip fracture (Crotty 2000), and another patients following a total knee replacement (Palmer Hill 2000). Out of the 21 trials eligible for the IPD, 11 recruited patients recovering from a stroke (Anderson 2000; Askim 2004; Bautz-Holter 2002; Donnelly 2004; Indredavik 2000; Manchester FASTER; Mayo 2000; Rodgers 1997; Rudd 1997; Suwenwela 2001; Widen-Holmqvist 1998), seven recruited older patients with a mix of conditions (Caplan 2006; Cunliffe 2004; Donald 1995; Harris 2005; Martin 1994; Richards 1998; Shepperd 1998) and three recruited patients with chronic obstructive pulmonary disease (COPD) (Cotton 2002; Ojoo 2002; Skwarska 2000). Four trials were excluded: two following discussion with the investigators (Melin 1993; Wade 1985) and two after extracting data (Hernandez 2003; Ronning 1998). The reasons for exclusion are listed in the 'Characteristics of excluded studies' table.

\section{Interventions}

In 13 trials care was provided in the patients' homes by a hospital outreach service (Anderson 2000; Askim 2004; Bautz-Holter 2002; Booth 2004; Caplan 2006; Cotton 2002; Crotty 2002; 
Donnelly 2004; Harris 2005; Mayo 2000; Ojoo 2002; Palmer Hill 2000; Skwarska 2000), in nine trials by community services (Adler 1978; Cunliffe 2004; Donald 1995; Martin 1994; Richards 1998; Rodgers 1997; Ruckley 1978; Shepperd 1998; Widen-Holmqvist 1998) and in four trials care was coordinated by a hospital based stroke team or physician in conjunction with community based services (Donnelly 2004; Indredavik 2000; Mayo 2000; Rudd 1997). In each trial the care provided by the intervention was primarily nursing, but with additional care sometimes being provided by care assistants or home helps. Hospital at home interventions in 14 trials described employing specialist and dedicated nurses (Anderson 2000; Askim 2004; Bautz-Holter 2002; Booth 2004; Caplan 2006; Cotton 2002; Crotty 2002; Cunliffe 2004; Donnelly 2004; Harris 2005; Mayo 2000; Ojoo 2002; Palmer Hill 2000; Skwarska 2000). Physiotherapy care was provided by 15 of the interventions (Anderson 2000; Askim 2004; Bautz-Holter 2002; Crotty 2000; Cunliffe 2004; Donald 1995; Harris 2005; Indredavik 2000; Mayo 2000; Palmer Hill 2000; Richards 1998; Rodgers 1997; Rudd 1997; Shepperd 1998; Widen-Holmqvist 1998) and occupational therapist care by 15 (Anderson 2000; Askim 2004; Bautz-Holter 2002; Crotty 2000; Cunliffe 2004; Donald 1995; Donnelly 2004; Harris 2005; Indredavik 2000; Mayo 2000; Richards 1998; Rodgers 1997; Rudd 1997; Shepperd 1998; Widen-Holmqvist 1998). A social worker was part of the hospital at home team in five of the interventions (Anderson 2000; Crotty 2002; Cunliffe 2004; Harris 2005; Rodgers 1997) and two interventions included a dietitian (Mayo 2000; Rodgers 1997). Access to a speech therapist was described in four of the interventions (Anderson 2000; Crotty 2002; Harris 2005; Rodgers 1997). In one trial rehabilitation was provided by trained Red Cross volunteers (Suwenwela 2001).

\section{Risk of bias in included studies}

Seven criteria are recommended by the Cochrane Effective Practice and Organisation of Care (EPOC) Group to judge the quality of randomised studies; these are described elsewhere (see 'METHODS USED IN REVIEWS', 'ASSESSMENT OF METHODOLOGICAL QUALITY' under 'GROUP DETAILS' in The Cochrane Library). One of the criteria, follow-up of professionals, was not relevant to the trials included in this review. The remaining six criteria were used. In 18 trials the method of randomisation and concealment of allocation was clearly described (see the 'Characteristics of included studies' table) (Anderson 2000; Askim 2004; Bautz-Holter 2002; Caplan 2006; Cotton 2002; Crotty 2000; Cunliffe 2004; Donald 1995; Donnelly 2004; Harris 2005; Martin 1994; Mayo 2000; Ojoo 2002; Richards 1998; Rodgers 1997; Rudd 1997; Shepperd 1998; Widen-Holmqvist 1998). For the remaining trials it was unclear. None of the included trials based their sample size on a difference in mortality. Multiple outcomes were measured in all of the trials. The type of care the con- trol group received was not clearly described for the majority of the trials.

\section{Effects of interventions}

Twenty six trials were included in this review $(\mathrm{n}=3967)$, and 21 of these were eligible for the IPD meta-analysis. Thirteen of these 21 trials contributed data to the IPD meta-analysis (1899/ 2872; 66\%). Of the eight trialists who were invited to contribute data but did not, two were unable to send their data (Cotton 2002; Skwarska 2000), three declined to participate (Caplan 2006; Donald 1995; Ojoo 2002) and three did not reply to requests to contribute data (Askim 2004; Indredavik 2000; Suwenwela 2001). Trials were conducted in the UK (Adler 1978; Booth 2004; Cotton 2002; Cunliffe 2004; Donald 1995; Donnelly 2004; Manchester FASTER; Martin 1994; Ojoo 2002; Palmer Hill 2000; Richards 1998; Rodgers 1997; Ruckley 1978; Rudd 1997; Shepperd 1998; Skwarska 2000), Australia (Anderson 2000; Caplan 2006; Crotty 2002) Canada (Mayo 2000), New Zealand (Harris 2005), Norway (Askim 2004; Bautz-Holter 2002; Indredavik 2000), Sweden ( Widen-Holmqvist 1998) and Thailand (Suwenwela 2001).

The main analysis is based on individual patient data; we used published data when we did not have access to IPD. We have also included tables using published data for comparison with the results of the IPD meta-analysis. We report the analyses by the patients' condition at recruitment: patients recovering from a stroke, older people with a mix of conditions, and those recovering from surgery.

\section{Patient outcomes for those recovering from a stroke}

Eleven trials recruited patients recovering from a stroke Anderson 2000; Askim 2004; Bautz-Holter 2002; Donnelly 2004; Indredavik 2000; Manchester FASTER; Mayo 2000; Rodgers 1997; Rudd 1997; Suwenwela 2001; Widen-Holmqvist 1998), of which nine contributed IPD.

\section{Mortality}

We combined IPD from seven trials recording the time to death at three to six months ( $\mathrm{n}=407$ ) (Anderson 2000; Bautz-Holter 2002; Cunliffe 2004; Donnelly 2004; Manchester FASTER; Shepperd 1998; Widen-Holmqvist 1998) Analysis 4.2. There was a non-significant reduction in mortality, adjusted for age and sex (HR 0.79, 95\% CI 0.32 to 1.91) (data from Anderson 2000 and Shepperd 1998 could not be adjusted as there were no events in the controls arms at follow-up). A sensitivity analysis of the effect of imputing missing dates, where we assigned the best and worse case scenarios to the intervention and comparison group, made little difference to the overall effect (Analysis 4.8; Analysis 4.9). We observed no significant heterogeneity. 


\section{Readmission}

We relied on published data from three trials $(n=179)$ for this analysis as the date of readmission was missing from all except one trial providing IPD. We found no significant difference in readmission rates between those allocated to hospital at home rather than to in-patient care (RR 1.06, 95\% CI 0.47 to 2.38) at three months follow-up (Analysis 1.9) (Bautz-Holter 2002; Rodgers 1997; Shepperd 1998) and at six months (RR 1.00, 95\% CI 0.63 to 1.60) (Analysis 1.10) (Anderson 2000; Bautz-Holter 2002; Widen-Holmqvist 1998). We observed no significant heterogeneity.

\section{Functional status}

We relied on published data from nine trials assessing functional status with a range of different measures: each trial reported no significant differences between groups (Anderson 2000; Askim 2004; Bautz-Holter 2002; Donnelly 2004; Mayo 2000; Rodgers 1997; Rudd 1997; Shepperd 1998; Suwenwela 2001). The individual trials may have been underpowered to detect a difference in each direction. One trial (Widen-Holmqvist 1998) reported that those allocated to hospital at home perceived significantly more dysfunction at three months follow-up on the psychosocial dimension of the Sickness Impact Profile (SIP) (home rehabilitation median 16.6, IQR 8.7 to 29.1; routine rehabilitation median 10.0, IQR 6.1 to $15.6, \mathrm{P}<0.02)$ compared with in-patient hospital care. These differences disappeared at six months follow-up. A second trial (Indredavik 2000) recruiting patients recovering from a stroke reported that significantly more patients allocated to hospital at home were independent for activities of daily living, measured by a score of $>2$ on the Rankin Scale at 26 weeks follow-up (OR $1.72,95 \%$ CI 1.10 to 2.7 ). A subgroup analysis excluding patients with a mild stroke detected a significant improvement in global independence measured by the Rankin Scale at 26 weeks followup (difference $17.7 \%, 95 \%$ CI $5.3 \%$ to $30.1 \%, P=0.006$ ) and activities of daily living measured by the Barthel Index (difference $13.6 \%$, 95\% CI $1.1 \%$ to $25.9 \%$; $\mathrm{P}=0.03$ ) (Analysis 1.1 ).

We combined IPD from two trials (Anderson 2000; Mayo 2000) measuring functional status with the Barthel Index using the standardised mean difference as each trial used a different scale. We found no overall difference between groups at three months $(\mathrm{N}$ $=174$, standardised mean difference $(\mathrm{SMD}) 0.1495 \% \mathrm{CI}-0.16$ to 0.43 ), or six months ( $\mathrm{N}=185$, SMD $0.02,95 \% \mathrm{CI}-0.27$ to 0.30) (Analysis 4.4; Analysis 4.5).

\section{Quality of life and patient assessed health status}

Each of the four trials measuring quality of life reported no significant differences, which may reflect that they were underpowered to detect a difference in either direction between groups (Anderson 2000; Askim 2004; Donnelly 2004; Rodgers 1997). One trial reported a significantly higher score at one month on the role physical subscale of the SF-36 for those allocated to early discharge hospital at home (mean difference 13.1; $\mathrm{P}<0.02$ ) and on the physical component summary of the SF36 at three months (mean difference 5.0; $\mathrm{P}<0.05$ ) (Mayo 2000) (Analysis 1.1).

\section{Psychological well being}

Two trials reported data on psychological well being; one reported a significantly lower score at three months (indicating better psychological well-being) for those allocated to early discharge hospital at home than to in-patient care on the General Health Questionnaire (median $(\mathrm{IQR})$ treatment $=19.5(14$ to 26$)$; control $=$ 26 (19 to 31 ); $95 \% \mathrm{CI}$ of the difference -9 to $-1, \mathrm{P}=0.02$ ). This difference disappeared at six months follow-up (Donnelly 2004). Rudd reported that $12 \%$ fewer people allocated to early discharge hospital at home reported anxiety on the Hospital Anxiety Depression scale (95\% CI -22\% to -0.81\%) (Rudd 1997) (Analysis $1.1)$.

\section{Patient satisfaction}

Two trials reported significantly higher levels of patient satisfaction for those allocated to hospital at home rather than to in-patient care (Donnelly 2004; Widen-Holmqvist 1998) and one trial no significant differences between groups (Anderson 2000) (Analysis $1.1)$.

\section{Place of residence at follow-up}

We combined published data on place of residence from four trials (Anderson 2000; Bautz-Holter 2002; Indredavik 2000; Rodgers 1997) finding that significantly fewer patients allocated to early discharge hospital at home were living in residential accommodation at six months follow-up (RR $0.63,95 \%$ CI 0.40 to 0.98 ) (Analysis 1.15).

\section{Carer outcomes}

Four trials measuring carer burden reported no significant differences between groups with the Carer Strain Index (Askim 2004; Donnelly 2004; Rudd 1997) or the GHQ 30 (Rodgers 1997) (Analysis 1.1).

\section{Length of stay}

We pooled published data from four trials and found a significant reduction in hospital length of stay (mean difference in days 6.68, 95\% CI -10.19 to -3.17) (Askim 2004; Mayo 2000; Rudd 1997; Shepperd 1998) (Analysis 1.17). Hospital length of stay was reduced in the remaining trials recruiting patients recovering from a stroke (Anderson 2000; Bautz-Holter 2002; Donnelly 2004; Indredavik 2000; Rodgers 1997) with a median reduction ranging from -8 days (Donnelly 2004) to -15 days (Anderson 2000). Two trials reported median length of stay in hospital at home; this 
ranged from five (range 1 to 19) (Anderson 2000) to nine weeks (range 1 to 44 weeks) (Rodgers 1997) (Analysis 1.1).

\section{Use of health service resources and cost}

Two trials reported no significant difference in cost to the health service between early discharge hospital at home and in-patient care (Donnelly 2004; Rudd 1997). In both trials costs for each patient were based on their use of health services. One trial reported a significant reduction in hospital costs per patient (Aus\$4678; $95 \%$ CI \$-6680 to \$-2676), although this became non-significant when community costs were taken into account (difference \$2013; 95\% CI \$-4696 to \$669) (Anderson 2000). A second trial Mayo 2000 reported a significant reduction in health service costs at three months for those allocated to hospital at home (mean difference Canadian $\$-3280.95, \mathrm{P}<0.0001$ ). In all four trials costs for each patient were based on their use of health services (see Analysis 1.1 for further details).

\section{Older people with a mix of conditions}

Seven trials recruited patients with a medical condition (Caplan 2006; Cunliffe 2004; Donald 1995; Harris 2005; Martin 1994; Richards 1998; Shepperd 1998) and three recruited patients with chronic obstructive pulmonary disease (COPD) (Cotton 2002; Ojoo 2002; Skwarska 2000). In one of these trials (Cunliffe 2004) $28 \%$ of the study population were recovering from a fracture, and in another $72 \%$ were recovering from surgery (Richards 1998). Five of these seven trials recruiting older patients with a medical condition contributed IPD, and one of these five trials recruited patients with COPD (Shepperd 1998). We combined the data from these trials.

\section{Mortality}

We combined IPD from four trials recording the time to death at three months (Cunliffe 2004; Harris 2005; Richards 1998; Shepperd 1998) and one trial $(\mathrm{n}=54)$ with six months follow-up (Martin 1994) adjusted for age and sex $(\mathrm{n}=980)$. There was no significant difference between groups (HR 1.06, 95\% CI 0.69 to 1.61) (Analysis 4.1). A sensitivity analysis of the effect of imputing missing dates, where we assigned the best and worse case scenarios to the intervention and comparison group, made little difference to the overall effect (Analysis 4.6 and Analysis 4.7). In addition we pooled the published data from six trials $(\mathrm{n}=1084)$; again there was no significant difference between groups (RR 1.12, 95\% CI 0.77 to 1.63 ) (Analysis 1.2).

We pooled published data from the trials recruiting patients with chronic obstructive pulmonary disease, which resulted in a nonsignificant reduction in mortality favouring hospital at home (RR $0.50,95 \%$ CI 0.23 to 1.09 ) (Analysis 1.7 ).

\section{Readmissions}

We combined IPD from three trials recording the time to readmission at three months $(\mathrm{N}=705)$ (Cunliffe 2004; Harris 2005; Shepperd 1998). There was a significant increase in readmissions for those allocated to hospital at home rather than in-patient care (adjusted for age and sex, HR 1.57; 95\% CI 1.10 to 2.24) (Analysis 4.3). The direction of effect remained the same in a pooled analysis of published data from five trials $(\mathrm{N}=969, \mathrm{RR} 1.35,95 \% \mathrm{CI}$ 1.03 to 1.76 ) (Analysis 1.8).

\section{Functional status and quality of life}

Five trials recruiting older patients with a medical condition (Caplan 2006; Donald 1995; Harris 2005; Martin 1994; Shepperd 1998), two trials recruiting patients with chronic obstructive airways disease (Ojoo 2002; Shepperd 1998) and one patients with a mix of conditions (primarily surgical) (Richards 1998) measured functional ability and/or quality life, and each trial reported no significant differences between those allocated to hospital at home and in-patient hospital care. We combined the published data from four of these trials measuring the Barthel Index and found no significant difference between groups (weighted mean difference 0.14 ; $95 \%$ CI -0.02 to 0.30 ) (Analysis 1.13 ). One trial recruiting older patients with a mix of medical and surgical conditions reported significantly improved scores for those allocated to early discharge hospital at home on two domains of the Nottingham Extended Activities of Daily Living Scale: kitchen (mean difference $1.1,95 \%$ CI 0.2 to 2.3 ), and domestic (mean difference 1.1, $95 \%$ CI 0.2 to 2.0) at three months follow-up. This trial also reported a significant difference for the Barthel Index favouring the early discharge group. At 12 months this improvement was sustained for the Nottingham Extended Activities of Daily Living domestic scale (mean difference 1.4, 95\% CI 0.4 to 2.4) (Cunliffe 2004).

\section{Psychological well being}

Five trials measuring psychological well being reported no significant differences between groups at follow-up (Caplan 2006; Donald 1995; Harris 2005; Martin 1994; Shepperd 1998). One trial reported significantly improved scores on the General Health Questionnaire for patients allocated to early discharge hospital at home (mean difference $-2.4,95 \%$ CI -4.1 to -0.7 ) at three months follow-up, and at 12 months follow-up (mean difference -1.9, 95\% CI -3.5 to -0.4) (Cunliffe 2004) (Analysis 1.1).

\section{Patient satisfaction}

Three trials recruiting older patients reported significantly increased levels of satisfaction for those allocated to early discharge hospital at home (Caplan 2006; Ojoo 2002; Shepperd 1998). One trial reported no significant differences between groups (Harris 2005). Some of the results were ambivalent, with patients reporting improved satisfaction on some domains and not others 
(Richards 1998; Shepperd 1998). One trial interviewed patients to find out how they viewed early discharge hospital at home care. The majority of patients were very positive about their experience, citing good communication, frequent and timely visits, and close attention to detail as positive aspects of the service (Cunliffe 2004) (Analysis 1.1)

\section{Place of residence}

We combined published data from three trials; significantly fewer people allocated to hospital at home were in residential care at one year follow-up (RR 0.69, 95\% CI 0.48 to 0.99) (Cunliffe 2004; Donald 1995; Martin 1994) (Analysis 1.14).

\section{Carer outcomes}

Three trials measuring self-reported carer satisfaction or burden (Gunnell 2000; Ojoo 2002; Shepperd 1998) reported no significant differences between the groups of carers. One trial reported that a greater number of carers in the hospital at home group compared with the in-patient group were happy with their allocated type of care (difference $42 \%$; $95 \%$ CI $12 \%$ to $72 \%$ ) (Ojoo 2002) (Analysis 1.1).

\section{Length of hospital stay}

We did not pool data for this outcome due to significant heterogeneity. There were non-significant reductions in hospital length of stay in three trials by five days (mean difference -5.12, 95\% CI -12.90 to 2.66) (Cunliffe 2004), 11 days (95\% CI -22.17 to 0.17 ) (Richards 1998) and less than one day (mean difference $0.36,95 \%$ CI -6.20 to 5.48) (Shepperd 1998). One trial reported a significant reduction of nearly 20 days (mean difference -19.78 , 95\% CI -28.27 to -11.29 ) (Caplan 2006). The trial by Donald et al reported a reduced length of stay for those receiving hospital at home, with a median reduction of six days $(\mathrm{P}=0.002)$ (Donald 1995); another trial reported a mean reduction of -22.4 days (Martin 1994). Two trials recruiting patients with COPD reported a non-significant reduction in hospital stay for those allocated to hospital at home of 1.5 days (Ojoo 2002) and just over three days (Cotton 2002). One trial reported a significant median reduction of two days (Skwarska 2000) (Analysis 1.1).

\section{Total days of care (hospital plus hospital at home)}

Data from three trials combining hospital length of stay with hospital at home days of care were pooled. Those allocated to hospital at home had significantly more days of care (mean difference 6.43, 95\% CI 2.84 to 10.03) (Harris 2005; Richards 1998 Shepperd 1998) (Analysis 1.19). Two other trials reported a significant increase in the total days of care received for those allocated to hospital at home (Cotton 2002; Ojoo 2002) (Analysis 1.1).

\section{Cost}

No significant difference between groups in health service costs for older medical patients was reported for one trial. This trial conducted a cost minimisation analysis from the perspective of the health service, taking into account the different resources used during a patient's hospital admission. However, a significant increase in cost for GP home and surgery visits was detected for those allocated to hospital at home (median difference $£ 22.65, \mathrm{P}<$ 0.01) (Shepperd 1998). Two trials recruiting patients with COPD reported a lower mean health service cost based on an average cost per bed day for patients allocated to early discharge hospital at home (Cotton 2002; Skwarska 2000), whereas another trial reported a significant increase in costs (median difference $£ 1132.00$, $\mathrm{P}<0.01$ ) when taking into account the different resources used during a patient's in-patient admission (Shepperd 1998). A fourth trial, recruiting older people with a mix of conditions, conducted a cost-effectiveness analysis and reported that early discharge hospital at home was less expensive than in-patient hospital care at 12 months follow-up (mean reduction per case $£ 1727, \mathrm{P}=0.05$ ). Costs of in-patient hospital care were based on length of stay and cost per bed day by clinical specialty using local NHS reference cost schedules for 2000 (Miller 2005). A sensitivity analysis halved the cost of the bed days to test the assumption that costs at the end of an episode of in-patient care may be lower than the initial days. This reduced the cost difference with data points on a costeffectiveness plane distributing more closely around the origin, meaning that hospital at home is not cost-effective if the reduction in resources used towards the end of in-patient admission is taken into account. However, the varying use of resources will depend on a patient's condition and a 50\% reduction in cost may not accurately reflect the marginal savings of early discharge. See Analysis 1.1 for further details of these results.

\section{Staff views}

One trial interviewed staff providing the early discharge hospital at home scheme to elicit their views on the way care was provided (Cunliffe 2004). There was a perception that providing care in the patients' homes facilitated patients' participation with their rehabilitation. Staff also reported that the service was better staffed than the usual after care services provided, and that rehabilitation services were coordinated with social care.

\section{Early discharge of patients following elective surgery}

The published results of six trials evaluating the effectiveness of hospital at home for patients discharged early from hospital following elective surgery are reported (Adler 1978; Booth 2004; Crotty 2000; Palmer Hill 2000; Ruckley 1978; Shepperd 1998). 


\section{Patient outcomes}

\section{Mortality}

One trial reported data on mortality, with one patient recovering from a hip replacement and allocated to in-patient care dying during the three month follow-up (Shepperd 1998).

\section{Re-admission to hospital}

Differences in study populations prevented data being combined and data are presented for individual trials in a forest plot (Analysis 1.23). One trial recruiting patients following surgery for hernia or varicose veins reported $0 / 117$ allocated to early discharge hospital at home versus $2 / 121$ patients allocated to in-patient care were re-admitted (Ruckley 1978), another that $2 / 37$ (5\%) versus $1 / 49$ (2\%) (RR 2.65, 95\% CI 0.25 to 28.11) of patients recovering from a hip replacement, $4 / 47$ (9\%) versus 1/39 (3\%) (RR 3.32, 95\% CI 0.39 to 28.49) of patients recovering from a knee replacement and $7 / 114(6 \%)$ versus $13 / 124$ (10\%) (RR $0.5995 \%$ CI 0.24 to 1.42 ) of patients recovering from a hysterectomy were re-admitted (Shepperd 1998).

\section{Patient assessed outcomes}

There was insufficient evidence of a difference in clinical complications, functional status, quality of life or psychological wellbeing between groups in two trials recruiting patients recovering from hernia repair or varicose vein surgery (Adler 1978; Ruckley 1978). Another trial (Shepperd 1998) reported improved quality of life on the Dartmouth COOP chart for patients allocated to hospital at home and recovering from a hip replacement (mean difference $0.5 ; 95 \%$ CI 0.13 to 0.88 ). A significant improvement was detected for patients recovering from a fractured neck of femur and allocated to hospital at home at four months followup on the Modified Barthel Index (median difference in change from baseline to follow-up of three points) and the Falls Efficacy Scale (median difference from baseline to follow-up of 11 points) (Crotty 2000). There was insufficient evidence of differences between groups for other measures of patient assessed outcome. One trial reported that $14 / 46(30 \%)$ of patients recovering from a knee replacement and allocated to hospital at home remained in hospital (Shepperd 1998); Palmer-Hill and colleagues report that 6\% of patients recovering from a knee replacement and allocated to hospital at home remained in hospital (Palmer Hill 2000) (Analysis 1.20).

\section{Patient satisfaction}

In one trial (Ruckley 1978) patients were asked their views about their care in terms of advantages and disadvantages. Patients in the early discharge group reported an increased advantage for themselves compared to those staying in hospital (difference 13.8\%;
95\% CI $5 \%$ to $23 \%, \mathrm{P}<0.01)$. However, these patients perceived their carers to be at a disadvantage (difference $21.8 \%, 95 \%$ CI 11\% to $32 \%, \mathrm{P}<0.001$ ). No significant differences were reported for satisfaction with services for patients recovering from a hip or knee replacement, hysterectomy (Shepperd 1998), hernia or varicose vein repair (Adler 1978) or a fracture neck of femur (Crotty 2000). Significantly more women recovering from a hysterectomy and allocated to hospital at home reported that they resumed parental responsibilities before being well enough (mean difference -0.24 on a scale of 0 to 3, 95\% CI -0.46 to -0.02) (Shepperd 1998). Differences were reported for patients' preferred place of care, with each group of patients preferring care at home (difference for patients recovering from a hip replacement $35.7 \%$, 95\% CI 16.7\% to $54.8 \%$; difference for patients recovering from a knee replacement $34 \%$, $95 \%$ CI $14 \%$ to $54 \%$; difference for women recovering from a hysterectomy $19 \%, 95 \%$ CI $8 \%$ to $30 \%$ ) (Shepperd 1998) (Analysis 1.20).

\section{Carer outcomes}

In one trial (Adler 1978) evaluating the early discharge of patients following elective surgery, carers in the early discharge group were less satisfied than those in the control group. In another trial (Ruckley 1978) carers were asked their views about the care the patients they were looking after received in terms of advantages and disadvantages. Carers looking after patients in the early discharge group reported an increased advantage for others involved in the patients' care (difference $16.6 \%, 95 \%$ CI $6.9 \%$ to $26 \%$ ) compared to patients who stayed in hospital for the usual length of stay. However, the carers perceived an added disadvantage for themselves (difference $22.6 \%, 95 \%$ CI $12 \%$ to $33 \%$ ) and for the patients they were caring for (difference $10.6 \%, 95 \%$ CI $1.2 \%$ to $20 \%$ ) compared to the carers looking after patients who stayed in hospital for the usual length of stay. Two other trials measuring carer satisfaction reported no significant differences for carers of patients recovering from a hip or knee replacement, hysterectomy (Shepperd 1998) or fractured neck of femur (Crotty 2000). However, a lower proportion of carers of women recovering from a hysterectomy reported hospital at home as their preferred place of care (difference -27\%, 95\% CI $-40 \%$ to -14\%) (Shepperd 1998) (Analysis 1.20).

\section{Hospital length of stay}

We combined data from four trials for patients recovering from orthopaedic surgery (Crotty 2000; Cunliffe 2004; Richards 1998; Shepperd 1998) with a mean reduction in hospital length of stay -4.44 days (95\% CI -6.37 to -2.51) (Analysis 1.21). One trial recruiting women recovering from a hysterectomy reported a significant reduction of -1.44 days $(-2.09$ to -0.79$)$, and another recruiting patients recovering from bypass surgery a significant reduction of -2.7 days; $\mathrm{P}<0.001$ (Booth 2004). 


\section{Total length of stay (hospital plus hospital at home)}

We combined data on patients recovering from orthopaedic surgery from two trials (Shepperd 1998; Richards 1998) for total days of care. There was a significant increase in total days of care for patients allocated to hospital at home compared with hospital care (mean difference 2.79; 95\% CI 0.77 to 4.81) (Analysis 1.22). No significant difference was observed for women recovering from a hysterectomy (mean difference 1.66; $95 \%$ CI 0.94 to 2.39) (Shepperd 1998). A significant increase of 14 days of care was reported for those recovering from a hip fracture $(95 \% \mathrm{CI}$ 7.58 to $20.42, \mathrm{P}<0.001)$ (Crotty 2000).

\section{Cost}

Three trials reported cost data (Adler 1978; Ruckley 1978; Shepperd 1998) and two provided estimates of cost that were not based on collection of resource data at the patient level for both arms of the trial (Adler 1978; Ruckley 1978), therefore it was not possible to calculate estimates of variance or conduct statistical analysis. One trial recruited patients with a mix of medical and surgical patients (Richards 1998) and reported that hospital at home was less costly than hospital care (measuring costs at the point of randomisation) (mean cost per patient over three months $£ 2516$ versus $£ 3292$ ). Although the hospital at home service was costed for each patient's use of resources, hospital services were not. In addition, the method used to collect the data did not allow statistical analyses to be conducted. It was, therefore, not possible to get an idea of the uncertainty associated with the estimates. The authors conducted a sensitivity analysis of hospital costs to assess the impact of using average costs. When hospital costs were taken as $50 \%$ of the original costs there was no significant difference in cost. However, it has been argued that $50 \%$ continues to overestimate the costs because of the non-linear relationship between cost of care and its intensity (Lilford 1998). Another trial conducting a cost minimisation analysis used patient dependency scores developed by hospital nursing and medical staff to reflect the marginal costs incurred during a patient's episode of hospital care (and hence the marginal savings of early discharge). These scores were used to estimate the costs of each day a patient was in hospital to reflect the differential use of resources during a patient's in-patient stay (Shepperd 1998). No significant difference in total health care costs between groups was detected for patients recovering from a hip or knee replacement and health care costs were significantly increased for women discharged early following a hysterectomy (difference $£ 92.39$, ratio of geometric mean 1.15, $95 \%$ CI 1.04 to 1.29 ). A sensitivity analysis reducing the number of hospital at home days altered the results for patients recovering from a hysterectomy. A reduction of one day eliminated the cost difference for women recovering from a hysterectomy, while a reduction of two days altered the costs making hospital at home the less expensive option for this patient group. This trial also reported no significant difference in costs to general practice for GP home or surgery visits. A trial recruiting patients recovering from bypass surgery reported a non-significant difference in health care costs at twelve weeks (Booth 2004) (Analysis 1.20).

\section{DISCUSSION}

We included 26 trials in this systematic review of early discharge hospital at home, of which 13 out of a possible 21 (66\% of the available patient data) contributed data to the IPD meta-analysis. We performed meta-analyses where there was sufficient similarity among the trials in terms of recruited participants and where common outcomes had been measured. Although there was insufficient evidence of differences between groups for mortality and readmission, and most measures of functional ability or quality of life, patients allocated to hospital at home had a significantly reduced risk of being in residential care at follow-up. This was true for patients recovering from a stroke and older patients with a mix of medical diagnoses. Overall hospital at home appears to result in an increase in patient satisfaction, and the little data available on carer burden indicate no self reported increase in burden.

It would be naïve to expect a complex intervention such as hospital at home to be equally effective for all those requiring medical care. Although any differences may reflect the way individual interventions are delivered, the effect appears to be consistent within the different patient groups, suggesting that the type of patient groups selected and the degree to which they rely on 'in-patient acute care' and rehabilitation is important. One trial, in a sensitivity analysis, found that the severity of the patient's condition determined the cost difference between early discharge hospital at home and inpatient care, with home based care being more cost-effective than hospital care if limited to patients with mild disability (Anderson 2000).

Early discharge hospital at home can be seen as a substitute for hospital care and as a means to control spending on acute hospital beds, although the provision of early discharge hospital at home can offset any reduction in hospital length of stay by increasing total length of care. However, even if hospital at home were to compare favourably with the cost of hospital care other factors may restrict the degree to which substitution could occur, including the carers' willingness to take on the responsibilities associated with hospital at home. This could reduce the already low volume of patients admitted to hospital at home, thus making the closure of a ward or hospital in favour of hospital at home an unrealistic option in some countries. Alternatively, hospital at home may be provided to supplement existing services, which could be an acceptable policy option for some groups of patients. However, the studies included in this review do not provide compelling evidence that hospital at home produces cost savings, nor that costs are shifted from secondary to primary care. 
It is important to take into account the transitional nature of hospital at home when determining effectiveness, particularly with early discharge hospital at home schemes. Ways of delivering health care services alter as the organisational boundaries of health care change. For example, two of the trials included in this review were conducted nearly 30 years ago. Both trials evaluated the early discharge of patients following elective surgery (Adler 1978; Ruckley 1978). However, given the overall reduction in hospital length of stay, the use of day case surgery and the introduction of minimally invasive surgery these trials have limited relevance today and data were not sought for the IPD meta-analysis. Conversely, there are some conditions, such as myocardial infarction, where it has been reported that admission to hospital has been avoided by the use of hospital at home (Mather 1976; Hill 1978). However, with the advent of thrombolytic therapy it may no longer be appropriate for these patients to receive all their care outside a secondary care setting. Problems can also arise when comparisons are made between countries. Interpreting the function of services in different health care systems is not always straightforward. For example, the expansion of home care services in some countries, such as the United States, may resemble primary care services already established in another country, not hospital at home care (Hughes 2000).

\section{A U THORS' CONCLUSIONS}

\section{Implications for practice}

This review does not support the widespread development of early discharge hospital at home services as a cheaper substitute for inpatient care within health care systems that have well developed primary care services; nor has it demonstrated that hospital at home is so hazardous or expensive that existing schemes for patients recovering from a stroke, and older patients recovering from a mix of conditions, including orthopaedic surgery and COPD, or patients who have had elective surgery, should be discontinued.

The environment in which these services are being delivered may influence outcome. It may be that schemes such as hospital at home provide a cost effective alternative to acute care if the running costs of the local hospital are relatively high. For example, the costs of a city teaching hospital are likely to exceed those of a district general hospital, making it more likely that an alternative service with few fixed costs, such as hospital at home, would compare favourably in terms of cost. Differences in the way the service is delivered may also account for differences in cost. Some of the trials included in the review evaluated hospital at home schemes that did not provide 24 hour care.

The low volume of patients admitted to hospital at home limits the degree to which these types of service reduce reliance on secondary care. Crotty and colleagues compared those eligible for their trial with those who were not, and found that while staff estimated that $36 \%$ of patients recovering from a fractured hip were eligible for their trial, only $20 \%$ were both eligible and consented to take part in the trial (Crotty 2000). Cunliffe and colleagues (Cunliffe 2004 ) report that just $2 \%$ of all medical admissions of older people to hospital were referred to an early discharge hospital at home scheme, and another trial that about 1\% were (Shepperd 1998). Crotty et al concluded that their hospital at home service was suitable for the least disabled group of patients and remains an unacceptable option for some patients and their families. The closure of a ward in favour of hospital at home becomes even less realistic if, as is often the case, patients are admitted to hospital at home from a variety of different wards and across a number of clinical areas. Although this has the advantage of increasing the number of patients admitted to hospital at home it makes it difficult to release resources from secondary care.

\section{Implications for research}

Future primary research should focus on rigorous evaluations of early discharge hospital at home schemes for the following patient groups: those recovering from a stroke, those with chronic obstructive pulmonary disease and older patients with a mix of medical conditions requiring an acute hospital in-patient stay. Trials should be large enough to rule out important differences in mortality and readmission. Patient health outcomes, patient and carer satisfaction, resource utilisation and costs should be measured using standardised methods and studies should include a formal, planned economic analysis using costs that are sensitive to the different resources used during an episode of care. To varying degrees researchers evaluating interventions with multiple components face difficulties in defining and interpreting the way an intervention, and its comparator, was delivered. The type of service being provided should be clearly defined, both at home and in hospital, and the patient groups described. Context may also have a role to play and should be accounted for with interventions such as hospital at home. For example, the development of other services at the primary-secondary care interface, such as community hospitals or rapid response health and social care teams, may affect the use of hospital beds and the type of services being offered as an alternative.

Such an ideal study may be difficult to mount, since the investment needed to create a service with sufficient patient numbers may be prohibitive, even if patients and carers could be recruited to it in the appropriate numbers. Individual patient data meta-analysis may continue to be the way forward. However, this requires agreement about the way data are measured and reported, and the recording of when key events such as death and readmission occurred.

Research data on how these types of schemes are implemented once the restrictions of a research design have been removed are lacking. Implementation research could shed light on the way these services function at the interface of primary and secondary care, how they may evolve outside a research setting, and why some of 
these services alter in terms of the types of patients they admit and the goals of the service. Related to this and to the expansion of this type of service are carer's views and the burden they may experience by participating in hospital at home care. While there are a small amount of data on those participating in trials little is known about how carer's view these types of service outside a research setting, i.e. those eligible but not consenting to take part in a trial and those outside a research setting who have the option of using hospital at home.

\section{ACKNOWLEDGEMENTS}

The authors would like to acknowledge the valuable advice from Mike Clarke and comments on earlier versions of this review from Jeremy Grimshaw and Andy Oxman.

\section{REFERE N C E S}

\section{References to studies included in this review}

Adler 1978 \{published data only\}

Adler MW, Waller JJ, Creese A, Thorne SC. Randomised controlled trial of early discharge for inguinal hernia and varicose veins. Journal of Epidemiology and Community Health 1978;32:136-42.

Anderson 2000 \{published data only\}

Anderson C, Mhurchu CN, Rubenach S, Clark M, Spencer C, Winsor A. Home or hospital for stroke rehabilitation? Results of a randomized controlled trial: II: cost minimization analysis at 6 months. Stroke 2000;31: 1032-7.

Anderson C, Rubenach S, Mhurchu CN, Clark M, Spencer C, Winsor A. Home or hospital for stroke rehabilitation? Results of a randomized controlled trial: I: health outcomes at 6 months. Stroke 2000;31:1024-31.

Askim 2004 \{published data only\}

Askim T, Rohweder G, Lydersen S, Indredavik B. Evaluation of an extended stroke unit service with early supported discharge for patients living in a rural community. A randomized controlled trial. Clinical Rehabilitation 2004; 18:238-48.

Bautz-Holter 2002 \{published and unpublished data\} Bautz-Holtert E, Sveen U, Rygh J, Rodgers H, Wyller TB. Early supported discharge of patients with acute stroke: a randomized controlled trial. Disability and Rehabilitation 2002;24:348-55.

Booth 2004 \{published data only\} Booth JE, Roberts JA, Flather M, Lamping DL, Mister R, Abdalla M, et al.A trial of early discharge with homecare compared to conventional hospital care for patients undergoing coronary artery bypass grafting. Heart 2004;90: 1344-5.

Caplan 2006 \{published data only\}

Caplan GA, Coconis J, Board N, Syers A, Woods J. Does home treatment affect delirium? A randomised controlled trial of rehabilitation of elderly and care at home or usual treatment (The REACH-OUT trial). Age and Ageing 2006; 35:53-60.

Cotton 2002 \{published data only\}

Cotton MM, Bucknall CE, Dagg KD, Johnson MK, MacGregor G, Stewart C, et al.Early discharge for patients with exacerbations of chronic obstructive pulmonary disease: a randomised controlled trial. Thorax 2000;55: $902-6$

Crotty 2002 \{published data only\} Crotty M, Whitehead CH, Gray S, Finucane PM. Early discharge and home rehabilitation after hip fracture achieves functional improvements: a randomised controlled trial. Clinical Rehabiliation 2002;16:406-13.

Cunliffe 2004 \{published and unpublished data\} * Cunliffe A, Gladman JRF, Husbands SL, Miller P, Dewey ME, Harwood RH. Sooner and healthier: a randomised controlled trial and interview study of an early discharge rehabilitation service for older people. Age and Ageing 2004; 33:246-52.

\section{Donald 1995 \{published data only\}}

Donald IP, Baldwin RN, Bannerjee M. Gloucester hospitalat-home: a randomized controlled trial. Age and Ageing 1995;24:434-9.

Donnelly 2004 \{published and unpublished data\} Donnelly M, Power M, Russell M, Fullerton K. Randomised controlled trial of an early discharge rehabilitation service: the Belfast community stroke trial. Stroke 2004;35:127-33.

Harris 2005 \{published and unpublished data\} Harris R, Ashton T, Broad J, Connolly G, Richmond D. The effectiveness, acceptability and costs of a hospitalat-home service compared with acute hospital care: a randomized controlled trial. Journal of Health Services and Research Policy 2005;10:158-66.

Indredavik 2000 \{published data only\} Indredavik B, Bakke F, Slordahl SA, Rokseth R, Haheim LL. Treatment in a combined acute and rehabilitation stroke unit. Stroke 2000;30:917-23.

Manchester FASTER \{unpublished data only\} Dey P, Woodman M. FASTER trial group. Not published.

Martin 1994 \{published and unpublished data\} Martin F, Oyewole A, Moloney A. A randomized controlled trial of a high support hospital discharge team for elderly people. Age and Ageing 1994;23:228-34.

Mayo 2000 \{published and unpublished data\}

Mayo NE, Wood-Dauphinee S, Cote R, Gayton D, Carlton J, Buttery J, et al.There's no place like home: an evaluation 
of early supported discharge for stroke. Stroke 2000;31: 1016-23.

Teng J, Mayo NE, Latimer E, Hanley J, Wood-Dauphinee $\mathrm{S}$, Cote R, et al.Costs and caregiver consequences of early supported discharge for stroke patients. Stroke 2003;34: 528-36.

Ojoo 2002 \{published data only\}

Ojoo JC, Moon T, McGlone S, Martin K, Gardiner ED, Greenstone MA, et al.Patients' and carers' preferences in two models of care for acute exacerbations of COPD: results of a randomised controlled trial. Thorax 2002;57:167-9.

\section{Palmer Hill 2000 \{published data only\}}

Palmer Hill S, Flynn J, Crawford EJP. Early discharge following total knee replacement - a trial of patient satisfaction and outcomes using an orthopaedic outreach team. Journal of Orthopaedic Nursing 2000;4:121-6.

Richards 1998 \{published and unpublished data\} * Coast J, Richards SH, Peters TJ, Gunnell DJ, Darlow MA, Pounsford J. Hospital at home or acute hospital care? A cost minimisation analysis. BMJ 1998;316:1802-6. Gunnell D, Coast J, Richards S, Peters T, Pounsford J, Darlow M. How great a burden does early discharge to hospital-at-home impose on carers? A randomized controlled trial. Age and Ageing 2000;29:137-42. Richards SH, Coast J, Gunnell DJ, Peters TJ, Pounsford J, Darlow MA. Randomised controlled trial comparing effectiveness and acceptability of an early discharge, hospital at home scheme with acute hospital care. BMJ 1998;316: 1796-801.

\section{Rodgers 1997 \{published and unpublished data\}} McNamee P, Christensen J, Soutter J, Rodgers H, Craig N, Pearson P. Cost analysis of early supported hospital discharge for stroke. Age and Ageing 1998;27:345-51. * Rodgers H, Soutter J, Kaiser W, Pearson P, Dobson $\mathrm{R}$, Skilbeck C, et al.Early supported hospital discharge following acute stroke: pilot study results. Clinical Rehabilitation 1997;11:280-7.

\section{Ruckley 1978 \{published data only\}}

Ruckley CV, Cuthbertson C, Fenwick N, Prescott RJ, Garraway WM. Day care after operations for hernia or varicose veins: a controlled trial. The British Journal of Surgery 1978;65:456-9.

\section{Rudd 1997 \{published and unpublished data\}}

Beech R, Rudd A, Tilling K, Wolfe C. Economic consequences of early inpatient discharge to community based rehabilitation for stroke in an inner London teaching hospital. Stroke 1999;30:729-35.

* Rudd AG, Wolfe CD, Tilling K, Beech R. Randomised controlled trial to evaluate early discharge scheme for patients with stroke. BMJ 1997;315:1039-44.

Shepperd 1998 \{published and unpublished data\} Shepperd S, Harwood D, Gray A, Vessey M, Morgan P. Randomised controlled trial comparing hospital at home care with inpatient hospital care. II: cost minimisation analysis. BMJ 1998;316:1791-6.

* Shepperd S, Harwood D, Jenkinson C, Gray A, Vessey M, Morgan P. Randomised controlled trial comparing hospital at home care with inpatient hospital care. I: three month follow up of health outcomes. BMJ 1998;316:1786-91.

Skwarska 2000 \{published data only\}

Skwarska E, Cohen G, Skwarski KM, Lamb C, Bushell D, Parker S, et al.Randomised controlled trial of supported discharge in patients with exacerbations of chronic obstructive pulmonary disease. Thorax 2000;55:907-12.

Suwenwela 2001 \{published data only\} Suwanwela NC, Phanthumchinda K, Limtongkul S, Suvanprakorn P. Thai Red Cross Volunteers Bureau. Comparison of short (3-day) hospitalization followed by home care treatment and conventional (10-day) hospitalization for acute ischemic stroke. Cerebrovascular Disease 2002;13(4):267-71.

Widen-Holmqvist 1998 \{published and unpublished data\} von Koch L, Widen Holmqvist L, Kostulas V, Almazan J de Pedro-Cuesta J. A randomized controlled trial of rehabilitation at home after stroke in southwest Stockholm: outcome at 6 months. Scandinavian Journal of Rehabilitation Medicine 2000;32:80-6.

* Widén Holmqvist L, von Koch L, Kostulas V, Holm M, Widsell G, Tegler H, et al.A randomized controlled trial of rehabilitation at home after stroke in southwest Stockholm. Stroke 1998;29:591-7.

\section{References to studies excluded from this review}

\section{Bonnema 1998 \{published data only\}}

Bonnema J, van Wersch A, van Geel A, Pruyn J, Schmitz PIM, Uyl-de-Groot CA, et al.Cost of care in a randomised trial of early hospital discharge after surgery for breast cancer. European Journal of Cancer 1998;34:2015-20.

Brooten 1994 \{published data only\} Brooten D, Roncoli M, Finkler S, Arnold L, Cohen A, Mennuti M. A randomized trial of early hospital discharge and home follow-up of women having cesarean birth. Obstetrics and Gynecology 1994;84:832-8.

Bundred 1998 \{published data only\} Bundred N, Maguire P, Reynolds J, Grimshaw J, Morris J, Thomson L, et al.Randomised controlled trial of effects of early discharge after surgery for breast cancer. BMJ 1998; 317:1275-9.

Cummings 1991 \{published data only\} * Cummings JE, Weaver FM. Cost-effectiveness of home care. Clinics in Geriatric Medicine 1991;7:865-74.

Farnworth 1994 \{published data only\} Farnworth MG, Kenny P, Shiell A. The costs and effects of early discharge in the management of fractured hip. Age and Ageing 1994;23:190-4.

Gerson 1976 \{published data only\} Gerson LW, Berry AF. Psycho-social effects of home care: results of a randomized controlled trial. International Journal of Epidemiology 1976;5:159-65. 


\section{Hansen 1992 \{published data only\}}

Hansen FR, Spedtsberg K, Schroll M. Geriatric follow-up by home visits after discharge from hospital: a randomized controlled trial. Age and Ageing 1992;21:445-50.

Hedrick 1986 \{published data only\}

Hedrick SC, Inui TS. The effectiveness and cost of home care: an information synthesis. Health Services Research 1986;20:851-80.

Hernandez 2003 \{published data only\} Hernandez C, Casas A, Escarrabill J, Alonso J, Puig-Junoy J, Farrero E, et al and partners in the CHRONIC project. Home hospitalisation of exacerbated chronic obstructive pulmonary disease patients. European Respiratory Journal 2003;21:58-67.

Hill 1978 \{published data only\}

Hill JD, Hampton JR, Mitchell JR. A randomised trial of home-versus-hospital management for patients with suspected myocardial infarction. Lancet 1978;1:837-41.

Klettke 1999 \{published data only\}

Klettke U, Magdorf K, Staab D, Bission S, Paul K, Wahn $\mathrm{U}$. Ambulatory vs. inpatient intravenous antibiotic therapy in mucoviscidosis patients - a controlled study [Mabulante vs stationare intravenose antibiotische Therapie bei Mukoviszidosepatienten - Einekontrollierte Studie]. Pneumologie 1999;53:31-6.

\section{Koopman 1996 \{published data only\}}

Koopman MM, Prandoni P, Piovella F, Ockelford PA, Brandjes DP, van der Meer J, et al.Treatment of venous thrombosis with intravenous unfractionated heparin administered in the hospital as compared with subcutaneous low-molecular-weight heparin administered at home. The Tasman Study Group. New England Journal of Medicine 1996;334:682-7.

\section{Levine 1996 \{published data only\}}

Levine M, Gent M, Hirsh J, Leclerc J, Anderson D, Weitz $\mathrm{J}$, et al.A comparison of low-molecular-weight heparin administered primarily at home with unfractionated heparin administered in the hospital for proximal deep-vein thrombosis. New England Journal of Medicine 1996;334: 677-81.

Magid 1989 \{published data only\}

Magid DM, Vokes EE, Schilsky RL, Guarnieri CM, Whaling SM, Weichselbaum RR, et al.A randomized study of inpatient versus outpatient continuous intravenous infusion chemotherapy: psychosocial aspects. Selective Cancer Therapeutics 1989;5:137-45.

Mather 1976 \{published data only\} Mather HG, Morgan DC, Pearson NG, Read KL, Shaw $\mathrm{DB}$, Steed GR, et al.Myocardial infarction: a comparison between home and hospital care for patients. BMJ 1976;1: 925-9.

\section{Melin 1992 \{published data only\}}

Melin AL, Bygren LO. Efficacy of the rehabilitation of elderly primary health care patients after short-stay hospital treatment. Medical Care 1992;30:1004-15.
Melin 1993 \{published data only\}

Melin AL, Hakansson S, Bygren LO. The cost-effectiveness of rehabilitation in the home: a study of Swedish elderly. American Journal of Public Health 1993;83:356-62.

Romano 1991 \{published data only\}

Romano L, Minicucci L, Spallone E, Girosi D, Campelli A, Fabbri A, et al.[Role of home therapy with ofloxacin in patients with cystic fibrosis (CF)]. Giornale Italiano di Chemioterapia 1991;38:181-3.

Ronning 1998 \{published data only\} Ronning OM, Guldvog B. Outcome of subacute stroke rehabilitation: a randomised controlled trial. Stroke 1998; 29:779-84.

Stone 1968 \{published data only\}

Stone JR, Patterson E, Felson L. The effectiveness of home care for general hospital patients. JAMA 1968;205:145-8.

\section{Wade 1985 \{published data only\}}

Wade DT, Langton-Hewer R, Skilbeck CE, Bainton D, Burns-Cox C. Controlled trial of a home-care service for acute stroke patients. Lancet 1985;1:323-6.

Williams 1981 \{published data only\}

Williams PL, Crawley JC, Freeman AM, Lloyd DC, Gumpel JM. Feasibility of outpatient management after intra-articular yttrium-90: comparison of two regimens. BMJ (Clinical Research Edition) 1981;282:13-4.

\section{Wolter 2004 \{published data only\}}

Wolter JM, Cagney RA, McCormack JG. A randomized trial of home vs hospital intravenous antibiotic therapy in adults with infectious diseases. Journal of Infection 2004; 48 : 263-8.

Zimmer 1984 \{published data only\} Zimmer JG, Groth-Juncker A, McCusker J. Effects of a physician-led home care team on terminal care. Journal of the American Geriatrics Society 1984;32:288-92.

Zimmer 1985 \{published data only\} Zimmer JG, Groth-Juncker A, McCusker J. A randomized controlled study of a home health care team. American Journal of Public Health 1985;75:134-41.

\section{Additional references}

\section{Bosna 1993}

Bosna E. KITTZ: innovation in home care. Capital Conference. King's Fund Centre, 1993.

\section{Clarke 1984}

Clarke F. Hospital at home: the alternative to general hospital admission. London, Basingstoke: Macmillan Publishers Ltd, 1984.

Cochran 1954

Cochran WG. The combination of estimates from different experiments. Biometrics 1954;10:101-29.

\section{Crotty 2000}

Crotty M, Kittel A, Hayball N. Home rehabilitation for older adults with fractured hips: how many will take part?. Journal of Quality in Clinical Practice 2000;20:65-8. 


\section{Deeks 1998}

Deeks J, Bradburn M, Bilker W, Localio R, Berlin J. Much ado about nothing: meta-analysis for rare events. 6th Cochrane Colloquium, Baltimore. 1998.

\section{EPOC 2008}

Bero L, Deane K, Eccles M, Grimshaw J, Gruen RL, Mayhew A, et al.Cochrane Effective Practice and Organisation of Care Group. The Cochrane Library. Chichester: Wiley-Blackwell. Updated quarterly 2008, issue 4.

\section{Gunnell 2000}

Gunnell D, Coast J, Richards SH, Peters TJ, Pounsford JC, Darlow MA. How great a burden does early discharge to hospital-at-home impose on carers? A randomized controlled trial. Age and Ageing 2000;29(2):137-42.

\section{Higgins 2003}

Higgins JPT, Thompson SG, Deeks JJ, Altman DG. Measuring inconsistency in meta-analysis. BMJ 2003;327: 557-60.

\section{Hollingworth 1993}

Hollingworth W, Todd C, Parker M, Roberts JA, Williams R. Cost analysis of early discharge after hip fracture. $B M J$ 1993;307:903-6.

Holmqvist 2000

Holmqvist, LW, von Koch L, Pdero-Cuesta J. Use of healthcare, impact on family caregivers and patient statisfaction of rehabilitation at home after stroke in South West Stockholm. Scandinavian Journal of Rehabilitation Medicine 2000;32:173-9.

\section{Hughes 2000}

Hughes SL, Weaver FM, Giobbe-Hurder A, Manheim L, Henderson W, Kubal JD, et al.Effectiveness of team managed home based primary care: a randomized multicenter trial. JAMA 2000;284:2877-85.

\section{Leff 2005}

Leff B, Burton L, Mader SL, Naughton B, Burl J, Inouye SK, et al.Hospital at home: feasibility and outcomes of a program to provide hospital level care at home for acutely ill older people. Annals of Internal Medicine 2005;143: 798-808.

\section{Lilford 1998}

Lilford RJ, Shaw H. Hospital at home. Costings were inadequate. BMJ 1998;317:1651-2.

\section{Matthews 2007}

Matthews PC, Conlon CP, Berendt AR, Kayley J, Jeffries L, Atkins BL. Outpatient parenteral antimicrobial therapy (OPAT): is it safe for selected patients to self administer at home? A retrospective analysis of a large cohort over 13 years. Journal of Antimicrobial Chemotherapy 2007;60: $356-62$.

\section{Miller 2005}

Miller P, Gladman JRF, Cunliffe AL, Husbands SL, Dewey ME, Harwood RH. Economic analysis of an early discharge rehabilitation service for older people. Age and Ageing 2005; 34:274-80.

Montalto 1998

Montalto M. How safe is hospital in the home care?. Medical Journal of Australia 1998;168:277-80.

\section{Morris 1983}

Morris DE. Sante Service Bayonne: a French approach to home care. Age and Ageing 1983;12:323-8.

\section{O'Cathain 1994}

O'Cathain A. Evaluation of a hospital at home scheme for the early discharge of patients with fractured neck of femur. Journal of Public Health Medicine 1994;16:205-10.

\section{Parker 2002}

Parker G, Bhakta P, Lovett CA, Paisley S, Olsen R, Turner $D$, et al.A systematic review of the costs and effectiveness of different models of paediatric home care. Health Technology Assessment 2002;6:iii-108.

Pryor 1989

Pryor GA, Williams DR. Rehabilitation after hip fractures. Home and hospital management compared. The Journal of Bone and Joint Surgery. British Volume. 1989;71:471-4.

\section{Shepperd 2005}

Shepperd S, Iliffe S. Hospital at home versus in-patient hospital care. Cochrane Database of Systematic Reviews 2005, Issue 3. [DOI: 10.1002/14651858.CD000356.pub2]

\section{Shepperd 2007}

Shepperd S, Doll H, Gowers S, James T, Fazel M, Pollock A, Fitzpatrick. Alternatives to inpatient mental health care for children and young people. Cochrane Database of Systematic Reviews 2007, Issue 1. [DOI: 10.1002/ 14651858.CD006410]

\section{Shepperd 2008}

Shepperd S, Doll H, Angus R, Clarke M, Iliffe S, Kalra L, Ricauda NA, Wilson A. Admission avoidance hospital at home. Cochrane Database of Systematic Reviews 2008, Issue 4. [DOI: 10.1002/14651858.CD007491]

\section{Shepperd 2011}

Shepperd S, Wee B, Straus SE. Hospital at home: home-based end of life care. Cochrane Database of Systematic Reviews 2011, Issue 7. [DOI: 10.1002/ 14651858.CD009231]

SPSS 2006

SPSS Inc. SPSS statistical software. SPSS Inc, 2006.

\section{STATA 2004}

College Station, TX: StataCorp LP. Stata Statistical Software. College Station, TX: StataCorp LP, 2004.

* Indicates the major publication for the study 
CHARACTERISTICS OF STUDIES

Characteristics of included studies [ordered by study ID]

Adler 1978

\begin{tabular}{|c|c|c|}
\hline Methods & \multicolumn{2}{|c|}{$\begin{array}{l}\text { RCT } \\
\text { Concealment of allocation: NOT CLEAR } \\
\text { Blinded assessment of outcomes: NOT CLEAR } \\
\text { Follow-up of patients: DONE } \\
\text { Baseline measurement: NOT DONE } \\
\text { Reliable primary outcome measures: DONE } \\
\text { Protection against contamination: NOT CLEAR }\end{array}$} \\
\hline Participants & \multicolumn{2}{|c|}{$\begin{array}{l}\text { Location: UK } \\
\text { Patients following elective surgery (hernia and varicose veins) } \\
\text { Age: } 18 \text { to } 64 \text { years } \\
\text { Treatment }=117 \\
\text { Control }=107 \\
\text { (in } 27 \text { months) }\end{array}$} \\
\hline Interventions & \multicolumn{2}{|c|}{$\begin{array}{l}\text { Hospital at home (early discharge) } \\
\text { Type of service: early discharge from hospital; no night care; organised by hospital surgeons, } \\
\text { provided by community; clinical responsibility held by GP } \\
\text { Skill mix and size of HAH teams: } \\
21 \text { home helps } \\
52 \text { district nurses } \\
\text { No dedicated staff } \\
\text { Control group: in-patient hospital care }\end{array}$} \\
\hline Outcomes & \multicolumn{2}{|l|}{$\begin{array}{l}\text { Clinical complications } \\
\text { Patient satisfaction } \\
\text { Carer satisfaction }\end{array}$} \\
\hline Notes & \multicolumn{2}{|l|}{$\begin{array}{l}\text { Outcomes measured at: } \\
7 \text { days } \\
6 \text { weeks } \\
2 \text { to } 3 \text { years for recurrence }\end{array}$} \\
\hline \multicolumn{3}{|l|}{ Risk of bias } \\
\hline Bias & Authors' judgement & Support for judgement \\
\hline Allocation concealment (selection bias) & High risk & $\mathrm{C}$ - Inadequate \\
\hline
\end{tabular}


Anderson 2000

\begin{tabular}{|c|c|c|}
\hline Methods & \multicolumn{2}{|c|}{$\begin{array}{l}\text { RCT } \\
\text { Concealment of allocation: DONE } \\
\text { Blinded assessment of outcomes: NOT CLEAR } \\
\text { Follow up of patients: } 1,3,6,12 \text { months } \\
\text { Baseline measurement: DONE } \\
\text { Reliable primary outcome measure: DONE } \\
\text { Protection against contamination: DONE }\end{array}$} \\
\hline Participants & \multicolumn{2}{|c|}{$\begin{array}{l}\text { Location: Australia } \\
\text { Patients recovering from a stroke } \\
\text { Mean age: } 72 \text { years } \\
\text { Treatment }=42 \\
\text { Control }=44\end{array}$} \\
\hline Interventions & \multicolumn{2}{|c|}{$\begin{array}{l}\text { Hospital at home early discharge } \\
\text { Type of service: specialist rehabilitation nurses; therapy sessions in patient's home and } \\
\text { individually tailored to achieve mutually agreed goals over several weeks. Emphasis on self- } \\
\text { learning, adjustment to disability and structured practice sessions were encouraged between } \\
\text { sessions } \\
\text { Occupational therapy, physiotherapy, speech therapist } \\
\text { Control group: in-patient hospital care }\end{array}$} \\
\hline Outcomes & \multicolumn{2}{|l|}{$\begin{array}{l}\text { Mortality } \\
\text { Health status } \\
\text { Functional status } \\
\text { Quality of life } \\
\text { Satisfaction } \\
\text { Readmissions } \\
\text { Length of stay }\end{array}$} \\
\hline \multicolumn{3}{|l|}{ Notes } \\
\hline \multicolumn{3}{|l|}{ Risk of bias } \\
\hline Bias & Authors' judgement & Support for judgement \\
\hline Allocation concealment (selection bias) & Low risk & A - Adequate \\
\hline
\end{tabular}


Askim 2004

\begin{tabular}{|c|c|c|}
\hline Methods & \multicolumn{2}{|c|}{$\begin{array}{l}\text { RCT } \\
\text { Concealment of allocation: DONE } \\
\text { Blinded assessment of outcomes: DONE } \\
\text { Follow-up of patients: } 6,26,52 \text { weeks } \\
\text { Baseline measurement: DONE } \\
\text { Reliable primary outcome measure: DONE } \\
\text { Protection against contamination: DONE }\end{array}$} \\
\hline Participants & \multicolumn{2}{|c|}{$\begin{array}{l}\text { Location: Norway } \\
\text { Patients recovering from a stroke } \\
\text { Mean age: treatment }=76.9 \text { control }=76.3 \\
\text { Treatment }=31 \\
\text { Control }=31\end{array}$} \\
\hline Interventions & \multicolumn{2}{|c|}{$\begin{array}{l}\text { Early discharge outreach } \\
\text { Type of service: physiotherapy, occupational therapy and dedicated nursing; stroke unit } \\
\text { home based programme of follow up care + primary health care. Home visit if patient live } \\
\text { within } 30 \text { to } 45 \text { minute radius of hospital, if greater than this the primary health team visitec } \\
\text { the home. Follow up plan made with family and primary health care providers. Mobil } \\
\text { team established a service and support system. Meeting with physician and stroke tean } \\
+ \text { patient and family on the day of discharge to define follow-up care plans. For patient } \\
\text { with extensive deficits plans for further rehabilitation were made. Once home contact wa } \\
\text { maintained by phone + at least one other home visit. Follow up by mobile team terminatec } \\
\text { with an out-patient consultation (for those living within } 30 \text { to } 40 \text { minutes away from th } \\
\text { hospital) or home visit (if more than } 35 \text { to } 40 \text { minutes). Local information meeting if } \\
\text { group of recruited patients lived in the same area } \\
\text { Control group: in-patient hospital care }\end{array}$} \\
\hline Outcomes & \multicolumn{2}{|l|}{$\begin{array}{l}\text { Mortality } \\
\text { Readmission } \\
\text { Functional status } \\
\text { Health status } \\
\text { Carer views } \\
\text { Length of stay }\end{array}$} \\
\hline \multicolumn{3}{|l|}{ Notes } \\
\hline \multicolumn{3}{|l|}{ Risk of bias } \\
\hline Bias & Authors' judgement & Support for judgement \\
\hline Allocation concealment (selection bias) & Low risk & A - Adequate \\
\hline
\end{tabular}


Bautz-Holter 2002

\begin{tabular}{|c|c|c|}
\hline Methods & \multicolumn{2}{|c|}{$\begin{array}{l}\text { RCT } \\
\text { Concealment of allocation: DONE } \\
\text { Blinded assessment of outcomes: DONE } \\
\text { Follow-up of patients: } 1 \text { week, } 3,6 \text { months } \\
\text { Baseline measurement: DONE } \\
\text { Reliable primary outcome measure: DONE } \\
\text { Protection against contamination: NOT CLEAR }\end{array}$} \\
\hline Participants & \multicolumn{2}{|c|}{$\begin{array}{l}\text { Location: Norway } \\
\text { Recovering from a stroke } \\
\text { Median age (IQR): treatment }=79.5 \text { ( } 69 \text { to } 84) \text {; control = } 78 \text { ( } 74 \text { to } 82) \\
\text { Treatment }=42 \\
\text { Control }=40\end{array}$} \\
\hline Interventions & \multicolumn{2}{|c|}{$\begin{array}{l}\text { Early discharge, hospital outreach community based rehabilitation } \\
\text { Type of service: multidisciplinary hospital based team ( } 1 \text { nurse, } 1 \text { occupational therapist, } \\
1 \text { physiotherapist) plus community nurses } \\
\text { Control group: in-patient hospital care }\end{array}$} \\
\hline Outcomes & \multicolumn{2}{|c|}{$\begin{array}{l}\text { Mortality } \\
\text { Functional ability } \\
\text { Psychological well being } \\
\text { Place of residence } \\
\text { Readmissions } \\
\text { Length of stay }\end{array}$} \\
\hline \multicolumn{3}{|l|}{ Notes } \\
\hline \multicolumn{3}{|l|}{ Risk of bias } \\
\hline Bias & Authors' judgement & Support for judgement \\
\hline Allocation concealment (selection bias) & Low risk & A - Adequate \\
\hline
\end{tabular}

\section{Booth 2004}

\begin{tabular}{ll} 
Methods & RCT \\
Concealment of allocation: NOT CLEAR \\
Blinded assessment of outcomes: NOT CLEAR \\
Follow-up of patients: 3 months \\
Baseline measurement: DONE \\
Reliable primary outcome measure: DONE \\
Protection against contamination: DONE \\
\hline Participants & Location: UK \\
& Patients with ischaemic heart disease, first time isolated bypass surgery \\
& Age: no data \\
& Treatment $=65$ \\
Control $=32$
\end{tabular}


Booth 2004 (Continued)

\begin{tabular}{lll}
\hline Interventions & $\begin{array}{l}\text { Early discharge outreach } \\
\text { Type of service: specialist hospital based nurses with enhanced preoperative preparation and } \\
\text { planned early discharge with specialist home care at 4 (+/-1) days after surgery. Admission } \\
\text { to hospital on the day of surgery } \\
\text { Control group: in-patient hospital care }\end{array}$ \\
\hline Outcomes & $\begin{array}{l}\text { Health status } \\
\text { Quality of life } \\
\text { Length of stay } \\
\text { Cost }\end{array}$ \\
\hline Notes & Had to have a carer available \\
\hline Risk of bias & Authors' judgement & Support for judgement \\
\hline Bias & Unclear risk & B - Unclear \\
\hline Allocation concealment (selection bias)
\end{tabular}

\section{Caplan 2006}

\begin{tabular}{|c|c|}
\hline Methods & $\begin{array}{l}\text { RCT } \\
\text { Concealment of allocation: DONE } \\
\text { Blinded assessment of outcomes: NOT DONE } \\
\text { Follow-up of patients: } 1 \text { and } 6 \text { months } \\
\text { Baseline measurement: DONE } \\
\text { Reliable primary outcome measure: DONE } \\
\text { Protection against contamination: DONE }\end{array}$ \\
\hline Participants & $\begin{array}{l}\text { Location: Australia } \\
\text { Elderly patients whose length of hospital stay exceeded } 6 \text { days, who were referred for geriatric } \\
\text { rehabilitation and expected to return home and live reasonably independently } \\
\text { Mean age: treatment }=83.86(7.8) \text {; control }=84.0(7.02) \\
\text { Treatment }=70 \\
\text { Control = } 34\end{array}$ \\
\hline Interventions & $\begin{array}{l}\text { Early discharge hospital based outreach } \\
\text { Type of service: nurses, physiotherapy, occupational therapy, physician } \\
\text { Control group: in-patient hospital care }\end{array}$ \\
\hline Outcomes & $\begin{array}{l}\text { Mortality } \\
\text { Functional and cognitive status } \\
\text { Psychological well being } \\
\text { Satisfaction } \\
\text { Readmission } \\
\text { Length of stay } \\
\text { Cost }\end{array}$ \\
\hline
\end{tabular}


Caplan 2006 (Continued)

Notes

Risk of bias

\begin{tabular}{lll}
\hline Bias & Authors' judgement & Support for judgement \\
\hline Allocation concealment (selection bias) & Low risk & A - Adequate \\
\hline
\end{tabular}

Cotton 2002

\begin{tabular}{|c|c|c|}
\hline Methods & \multicolumn{2}{|c|}{$\begin{array}{l}\text { RCT } \\
\text { Concealment of allocation: DONE } \\
\text { Blinded assessment of outcomes: NO } \\
\text { Follow-up of patients: } 2 \text { months } \\
\text { Baseline measurement: DONE } \\
\text { Reliable primary outcome measure: DONE } \\
\text { Protection against contamination: DONE }\end{array}$} \\
\hline Participants & \multicolumn{2}{|c|}{$\begin{array}{l}\text { Location: UK } \\
\text { Patients with chronic obstructive pulmonary disease, recruited from medical wards } \\
\text { Mean age: treatment }=65.7(\text { SD 1.6); control = } 68(\text { SD 1.2) } \\
\text { Treatment }=41 \\
\text { Control = } 40\end{array}$} \\
\hline Interventions & \multicolumn{2}{|c|}{$\begin{array}{l}\text { Hospital at home (early discharge) } \\
\text { Type of service: emergency admissions recruited from the ward (early discharge within } \\
3 \text { days of readmission) respiratory nurse (did not prescribe), GP provided out of hours } \\
\text { medical care } \\
\text { Control group: in-patient hospital care }\end{array}$} \\
\hline Outcomes & \multicolumn{2}{|l|}{$\begin{array}{l}\text { Readmission } \\
\text { Hospital length of stay } \\
\text { Mortality }\end{array}$} \\
\hline \multicolumn{3}{|l|}{ Notes } \\
\hline \multicolumn{3}{|l|}{ Risk of bias } \\
\hline Bias & Authors' judgement & Support for judgement \\
\hline Allocation concealment (selection bias) & Low risk & A - Adequate \\
\hline
\end{tabular}




\begin{tabular}{|c|c|c|}
\hline Methods & \multicolumn{2}{|c|}{$\begin{array}{l}\text { RCT } \\
\text { Concealment of allocation: DONE } \\
\text { Follow up of patients: } 4 \text { months } \\
\text { Blinded assessment of outcomes: YES (ASSESSOR, NOT PATIENT) } \\
\text { Baseline measurement: DONE } \\
\text { Reliable primary outcome measure: DONE } \\
\text { Protection against contamination: DONE }\end{array}$} \\
\hline Participants & \multicolumn{2}{|c|}{$\begin{array}{l}\text { Location: Australia ( } 3 \text { metropolitan hospitals, Adelaide) } \\
\text { Patients with a hip fracture, excluded from participating if they did not have a telephone } \\
\text { at home or inadequate social support } \\
\text { Median age: treatment }=81.6 \text {; control }=83.5 \\
\text { Treatment }=34 \\
\text { Control }=32\end{array}$} \\
\hline Interventions & \multicolumn{2}{|c|}{$\begin{array}{l}\text { Hospital at home (early discharge) } \\
\text { Type of service: rehabilitation: physiotherapy, occupational therapy, speech therapist, social } \\
\text { worker, therapy aid, nursing care, and assistance with shopping and cleaning; based on } \\
\text { short term treatment goals negotiated with patient and carer. Therapy adapted to rate of } \\
\text { patient's progress } \\
\text { Control group: in-patient hospital care }\end{array}$} \\
\hline Outcomes & \multicolumn{2}{|c|}{$\begin{array}{l}\text { Mobility (Timed Up \& Go) } \\
\text { Physical function: activities - specific Balance Confidence Scale, Falls Efficacy Scale, Berg } \\
\text { Balance Scale, London Handicap Scale } \\
\text { Health related quality of life (SF 36) } \\
\text { Adverse events } \\
\text { Patient \& carer satisfaction } \\
\text { Carer strain (Caregiver Strain Index) }\end{array}$} \\
\hline \multicolumn{3}{|l|}{ Notes } \\
\hline \multicolumn{3}{|l|}{ Risk of bias } \\
\hline Bias & Authors' judgement & Support for judgement \\
\hline Allocation concealment (selection bias) & Low risk & A - Adequate \\
\hline
\end{tabular}


Cunliffe 2004

\begin{tabular}{|c|c|c|}
\hline Methods & \multicolumn{2}{|c|}{$\begin{array}{l}\text { RCT } \\
\text { Concealment of allocation: DONE } \\
\text { Follow up: } 1,3 \text { and } 12 \text { months } \\
\text { Blinded assessment of outcomes: NO } \\
\text { Baseline measurement: DONE } \\
\text { Reliable primary outcome measure: DONE } \\
\text { Protection against contamination: DONE }\end{array}$} \\
\hline Participants & \multicolumn{2}{|c|}{$\begin{array}{l}\text { Location: UK (Nottingham) } \\
3 \text { most common conditions were fractures }(105 / 370,28 \%) \text {, neurological conditions, mainly } \\
\text { stroke }(97 / 370,26 \%) \text {, cardio-respiratory illnesses }(50 / 370,14 \%) .247 / 370(66 \%) \text { lived } \\
\text { alone } \\
\text { Median age: } 80 \text { years } \\
\text { Treatment }=185 \\
\text { Control }=185\end{array}$} \\
\hline Interventions & \multicolumn{2}{|c|}{$\begin{array}{l}\text { Hospital at home (early discharge) } \\
\text { Type of service: provided by community services, GP had clinical responsibility, physio } \\
\text { therapy, occupational therapy, } 3 \text { dedicated nurses plus } 7 \text { rehabilitation assistants, providec } \\
\text { care up to } 4 \text { weeks. Community care officer liaised with social services } \\
\text { Control group: in-patient hospital care }\end{array}$} \\
\hline Outcomes & \multicolumn{2}{|c|}{$\begin{array}{l}\text { Mortality } \\
\text { Readmission } \\
\text { Functional ability } \\
\text { Quality of life } \\
\text { Psychological well-being (patient and carer) } \\
\text { Cost }\end{array}$} \\
\hline \multicolumn{3}{|l|}{ Notes } \\
\hline \multicolumn{3}{|l|}{ Risk of bias } \\
\hline Bias & Authors' judgement & Support for judgement \\
\hline Allocation concealment (selection bias) & Low risk & A - Adequate \\
\hline
\end{tabular}

\section{Donald 1995}

$\begin{array}{ll}\text { Methods } & \text { RCT } \\ \text { Concealment of allocation: DONE } \\ \text { Blinded assessment of primary outcomes: NOT DONE } \\ \text { Follow up of patients: DONE (6 weeks, } 12 \text { weeks, } 6 \text { months) } \\ \text { Baseline measurement: DONE } \\ \text { Reliable primary outcome measures: DONE } \\ \text { Protection against contamination: NOT CLEAR }\end{array}$


Donald 1995 (Continued)

\begin{tabular}{|c|c|c|}
\hline Participants & \multicolumn{2}{|c|}{$\begin{array}{l}\text { Location: UK } \\
\text { Elderly medical patients } \\
\text { Age: } 76 \text { to } 90 \text { years } \\
\text { Number of patients in } 5 \text { months: treatment }=30 \text {; control }=30\end{array}$} \\
\hline Interventions & \multicolumn{2}{|c|}{$\begin{array}{l}\text { Hospital at home (early discharge) } \\
\text { Type of service: organised by hospital, provided by community; GP provided routine and } \\
\text { emergency care } \\
\text { Type of scheme: early discharge; not clear if } 24 \text {-hour care provided; time limit of } 6 \text { weeks } \\
\text { Skill mix: } 1 \text { nurse manager, } 1 \text { physiotherapist, } 1 \text { occupational therapist, } 3 \text { assistants (part } \\
\text { time) } \\
\text { Control group: in-patient hospital care }\end{array}$} \\
\hline Outcomes & \multicolumn{2}{|c|}{$\begin{array}{l}\text { Mortality } \\
\text { Functional status } \\
\text { Psychological well-being } \\
\text { In-patient hospital days } \\
\text { Use of other health services }\end{array}$} \\
\hline \multicolumn{3}{|l|}{ Notes } \\
\hline \multicolumn{3}{|l|}{ Risk of bias } \\
\hline Bias & Authors' judgement & Support for judgement \\
\hline Allocation concealment (selection bias) & Low risk & A - Adequate \\
\hline
\end{tabular}

Donnelly 2004

\begin{tabular}{ll}
\hline Methods & RCT \\
Concealment of allocation: DONE & $\begin{array}{l}\text { Blinded assessment of outcomes: NOT DONE (just at baseline) } \\
\text { Follow-up of patients: } 12 \text { months } \\
\text { Baseline measurement: DONE } \\
\text { Reliable primary outcome measure: DONE } \\
\text { Protection against contamination: DONE }\end{array}$ \\
\hline Participants & $\begin{array}{l}\text { Location: UK (Belfast) } \\
\text { Recovering from a stroke } \\
\text { Median age: treatment }=68 ; \text { control = 71 } \\
\text { Treatment = 54 } \\
\text { Control = 59 }\end{array}$ \\
\hline Interventions & $\begin{array}{l}\text { Early discharge community based } \\
\text { Type of service: average of } 2.5 \text { home visits a week for } 3 \text { months, each visit lasting } 45 \text { minutes. } \\
\text { Multidisciplinary meetings held to discuss the assessment of patients and progress towards } \\
\text { rehabilitation goals, which were set by relatives, patient and therapist. Patients discharged to } \\
\text { home following home assessment and placement of aids and equipment. Physiotherapist, }\end{array}$ \\
\hline
\end{tabular}




\begin{tabular}{ll}
\hline Outcomes & Mortality \\
& Readmission \\
& Functional status \\
& Quality of life \\
Satisfaction \\
& Carer burden \\
& Length of stay \\
& Cost \\
\hline Notes & \\
\hline
\end{tabular}

Risk of bias

\begin{tabular}{lll}
\hline Bias & Authors' judgement & Support for judgement \\
\hline Allocation concealment (selection bias) & Low risk & A - Adequate \\
\hline
\end{tabular}

\section{Harris 2005}

\begin{tabular}{|c|c|}
\hline Methods & $\begin{array}{l}\text { RCT } \\
\text { Concealment of allocation: DONE } \\
\text { Blinded assessment of outcomes: NOT DONE } \\
\text { Follow-up of patients: 10, } 30,90 \text { days } \\
\text { Baseline measurement: DONE } \\
\text { Reliable primary outcome measure: DONE } \\
\text { Protection against contamination: DONE }\end{array}$ \\
\hline Participants & $\begin{array}{l}\text { Location: New Zealand } \\
\text { In hospital for less than } 36 \text { hours in the emergency department of acute assessment ward } \\
\text { (admission avoidance), or admitted and with help of hospital at home services could be } \\
\text { discharged home earlier than would otherwise have been the case (early discharge). Patients } \\
\text { had a broad range of diagnoses: fractures }(28 \%) \text {; miscellaneous medical problems }(18 \%) \\
\text {; respiratory problems }(16 \%) \text {; stroke and neurological diagnoses }(14 \%) \text {; falls and injuries } \\
(11 \%) \text {; cardiac diagnoses }(8 \%) \text {; and rehabilitation and other problems }(5 \%) \\
\text { Mean age: } 80 \text { years }(80.7 \% \text { aged < } 75 \text { years) } \\
\text { Treatment = } 143 \\
\text { Control = } 142\end{array}$ \\
\hline Interventions & $\begin{array}{l}\text { Early discharge hospital based outreach } \\
\text { Type of service: coordinated rehabilitation multidisciplinary team - } \\
\text { physiotherapy, occupational therapy, social care, nursing } \\
\text { Control group: in-patient hospital care }\end{array}$ \\
\hline Outcomes & $\begin{array}{l}\text { Mortality } \\
\text { Readmission } \\
\text { Functional status }\end{array}$ \\
\hline
\end{tabular}


Harris 2005 (Continued)

Cognitive status

Quality of life

Satisfaction

Carer burden

Length of stay

Cost

Notes

Risk of bias

\begin{tabular}{lll} 
Bias & Authors' judgement & Support for judgement \\
\hline Allocation concealment (selection bias) & Low risk & A - Adequate \\
\hline
\end{tabular}

Indredavik 2000

$\begin{array}{ll}\text { Methods } & \text { RCT } \\ \text { Concealment of allocation: NOT CLEAR } \\ \text { Follow up of patients: 6 weeks, 26 weeks } \\ \text { Blinded assessment of outcomes: YES } \\ \text { Baseline measurement: DONE } \\ \text { Reliable primary outcome measure: DONE } \\ \text { Protection against contamination: DONE }\end{array}$

Risk of bias

Bias

Authors' judgement

Support for judgement 
Indredavik 2000 (Continued)

$\begin{array}{lll}\text { Allocation concealment (selection bias) } & \text { Unclear risk } & \text { B - Unclear }\end{array}$

\section{Manchester FASTER}

\begin{tabular}{|c|c|c|}
\hline Methods & \multicolumn{2}{|l|}{$\begin{array}{l}\text { RCT } \\
\text { No details on methods }\end{array}$} \\
\hline Participants & \multicolumn{2}{|c|}{$\begin{array}{l}\text { Location: UK } \\
\text { Patients recovering from a stroke }\end{array}$} \\
\hline Interventions & \multicolumn{2}{|c|}{ Hospital at home (early discharge) } \\
\hline Outcomes & \multicolumn{2}{|l|}{ Mortality } \\
\hline \multicolumn{3}{|l|}{ Notes } \\
\hline \multicolumn{3}{|l|}{ Risk of bias } \\
\hline Bias & Authors' judgement & Support for judgement \\
\hline Allocation concealment (selection bias) & Unclear risk & B - Unclear \\
\hline
\end{tabular}

\section{Martin 1994}

\begin{tabular}{|c|c|}
\hline Methods & $\begin{array}{l}\text { RCT } \\
\text { Concealment of allocation: DONE } \\
\text { Blinded assessment of primary outcomes: NOT CLEAR } \\
\text { Follow up of patients: DONE ( } 6 \text { weeks, } 12 \text { weeks, } 1 \text { year) } \\
\text { Baseline measurement: DONE } \\
\text { Reliable primary outcome measures: DONE } \\
\text { Protection against contamination: NOT CLEAR }\end{array}$ \\
\hline Participants & $\begin{array}{l}\text { Location: UK } \\
\text { Elderly medical patients } \\
\text { Average age: } 81.5 \text { years } \\
\text { Number of patients in } 9 \text { months: } \\
\text { Treatment }=29 \\
\text { Control }=25\end{array}$ \\
\hline Interventions & $\begin{array}{l}\text { Hospital at home (early discharge) } \\
\text { Type of service: hospital based; GP has clinical responsibility; no night care } \\
\text { Skill mix of HAH team: } 1 \text { nurse manager; } 10 \text { unqualified staff } \\
\text { Control group: in-patient hospital care }\end{array}$ \\
\hline Outcomes & $\begin{array}{l}\text { Mortality } \\
\text { Functional status } \\
\text { Psychological well-being }\end{array}$ \\
\hline
\end{tabular}


Martin 1994 (Continued)

Cognitive status

Readmission

Use of other health services

Patients' place of residence at follow-up

Notes

Risk of bias

\begin{tabular}{lll}
\hline Bias & Author' judgement & Support for judgement \\
\hline Allocation concealment (selection bias) & Low risk & A - Adequate \\
\hline
\end{tabular}

\section{Mayo 2000}

\begin{tabular}{|c|c|c|}
\hline Methods & \multicolumn{2}{|c|}{$\begin{array}{l}\text { RCT } \\
\text { Concealment of allocation: DONE } \\
\text { Blinded assessment of outcomes: NOT DONE } \\
\text { Follow-up of patients: } 1,3 \text { months } \\
\text { Baseline measurement: DONE } \\
\text { Reliable primary outcome measure: DONE } \\
\text { Protection against contamination: DONE }\end{array}$} \\
\hline Participants & \multicolumn{2}{|c|}{$\begin{array}{l}\text { Location: Canada } \\
\text { Patients recovering from a stroke } \\
\text { Mean age: treatment }=70.3(12.7) \text {; control }=69.6(12.7) \\
\text { Treatment }=58 \\
\text { Control }=56\end{array}$} \\
\hline Interventions & \multicolumn{2}{|c|}{$\begin{array}{l}\text { Early discharge hospital outreach } \\
\text { Type of service: multi-disciplinary team: physiotherapist, occupational therapist, dedicated } \\
\text { nurses, speech therapist } \\
\text { Control group: in-patient hospital care }\end{array}$} \\
\hline Outcomes & \multicolumn{2}{|l|}{$\begin{array}{l}\text { Mortality } \\
\text { Functional status } \\
\text { Quality of life } \\
\text { Length of stay }\end{array}$} \\
\hline \multicolumn{3}{|l|}{ Notes } \\
\hline \multicolumn{3}{|l|}{ Risk of bias } \\
\hline Bias & Authors' judgement & Support for judgement \\
\hline Allocation concealment (selection bias) & Low risk & A - Adequate \\
\hline
\end{tabular}


Ojoo 2002

\begin{tabular}{|c|c|c|}
\hline Methods & \multicolumn{2}{|c|}{$\begin{array}{l}\text { RCT } \\
\text { Concealment of allocation: DONE } \\
\text { Blinded assessment of outcomes: NOT DONE } \\
\text { Follow- up of patients: } 3 \text { months } \\
\text { Baseline measurement: DONE } \\
\text { Reliable primary outcome measure: DONE } \\
\text { Protection against contamination: DONE }\end{array}$} \\
\hline Participants & \multicolumn{2}{|c|}{$\begin{array}{l}\text { Location: UK } \\
\text { Patients with chronic obstructive airways disease } \\
\text { Mean age: treatment }=69.7 \text {; control }=70.1 \\
\text { Treatment }=30 \\
\text { Control }=30\end{array}$} \\
\hline Interventions & \multicolumn{2}{|c|}{$\begin{array}{l}\text { Hospital at home (early discharge within } 48 \text { hours of admission) } \\
\text { Type of service: daily monitoring by } 2 \text { respiratory outreach nurses who were accessible by } \\
\text { phone daily from 9:00 to 17:00, out of hours advice from Medical Chest Unit: GPs aware } \\
\text { but not involved in care } \\
\text { Those living alone with no phone were excluded from the trial } \\
\text { Control group: in-patient hospital care }\end{array}$} \\
\hline Outcomes & \multicolumn{2}{|c|}{$\begin{array}{l}\text { Length of stay } \\
\text { Days of care } \\
\text { Symptom score } \\
\text { Respiratory function } \\
\text { Patient and carer satisfaction }\end{array}$} \\
\hline Notes & \multicolumn{2}{|c|}{ Follow-up: 2 weeks for satisfaction, 3 months for readmission } \\
\hline \multicolumn{3}{|l|}{ Risk of bias } \\
\hline Bias & Authors' judgement & Support for judgement \\
\hline Allocation concealment (selection bias) & Low risk & A - Adequate \\
\hline
\end{tabular}

\section{Palmer Hill 2000}

\begin{tabular}{ll}
\hline Methods & RCT \\
& Concealment of allocation: NOT CLEAR (10/70, 14\%, withdrew after randomisation and \\
excluded from analysis) & Follow up of patients: 5 days, 6 weeks, 12 weeks, 1 year \\
Blinded assessment of outcomes: NOT CLEAR \\
Baseline measurement: DONE \\
Reliable primary outcome measure: DONE \\
Protection against contamination: DONE \\
\hline Participants & $\begin{array}{l}\text { Location: UK } \\
\text { Patients recovering from a knee replacement } \\
\text { Age - no data }\end{array}$ \\
\hline
\end{tabular}


Palmer Hill 2000 (Continued)

Treatment $=32$

Control $=28$

\begin{tabular}{|c|c|c|}
\hline Interventions & \multicolumn{2}{|c|}{$\begin{array}{l}\text { Hospital at home (early discharge) } \\
\text { Type of service: orthopaedic outreach team ( } 2 \text { orthopaedic nurses, a health care assistant, a } \\
\text { physiotherapist) provide domiciliary care and a } 24 \text { hour on call service } \\
\text { Control group: in-patient hospital care }\end{array}$} \\
\hline Outcomes & \multicolumn{2}{|c|}{$\begin{array}{l}\text { Clinical condition of the knee joint } \\
\text { Complications } \\
\text { Readmission } \\
\text { Patient satisfaction }\end{array}$} \\
\hline \multicolumn{3}{|l|}{ Notes } \\
\hline \multicolumn{3}{|l|}{ Risk of bias } \\
\hline Bias & Authors' judgement & Support for judgement \\
\hline Allocation concealment (selection bias) & Unclear risk & B - Unclear \\
\hline
\end{tabular}

Richards 1998

\begin{tabular}{|c|c|}
\hline Methods & $\begin{array}{l}\text { RCT } \\
\text { Concealment of allocation: DONE } \\
\text { Follow up of patients: } 3 \text { months } \\
\text { Blinded assessment of outcomes: NO } \\
\text { Follow- up of patients: } 1 \text { AND } 3 \text { months } \\
\text { Baseline measurement: DONE } \\
\text { Reliable primary outcome measure: DONE } \\
\text { Protection against contamination: NOT CLEAR }\end{array}$ \\
\hline Participants & $\begin{array}{l}\text { Location: UK } \\
\text { Elderly patients recovering from elective surgery or emergency medical admissions }(31 \% \\
\text { fracture neck of femur, } 21 \% \text { other fractures, } 11 \% \text { hip replacement, } 10 \% \text { cerebrovascular } \\
\text { accidents, } 10 \% \text { knee replacements, } 22 \% \text { miscellaneous reasons for admission) } \\
\text { Mean age: } 78.3 \text { (SD } 6.9) \text { - from IPD dataset } \\
\text { Treatment }=160 \text { (of which } 50 / 160 \text { had a medical diagnosis) } \\
\text { Control = } 81 \text { (of which } 25 / 81 \text { had a medical diagnosis) }\end{array}$ \\
\hline Interventions & $\begin{array}{l}\text { Hospital at home (early discharge) } \\
\text { Type of service: early discharge from hospital; no night care } \\
\text { Control group: hospital care which included development of care pathways and discharge } \\
\text { planning } \\
\text { Control group: in-patient hospital care }\end{array}$ \\
\hline Outcomes & Resource and cost \\
\hline Notes & \\
\hline
\end{tabular}

Copyright $\odot 201$ I The Cochrane Collaboration. Published by John Wiley \& Sons, Ltd. 
Richards 1998 (Continued)

\begin{tabular}{lll} 
Risk of bias & & \\
\hline Bias & Authors' judgement & Support for judgement \\
\hline Allocation concealment (selection bias) & Low risk & A - Adequate \\
\hline
\end{tabular}

\section{Rodgers 1997}

\begin{tabular}{|c|c|c|}
\hline Methods & \multicolumn{2}{|c|}{$\begin{array}{l}\text { RCT } \\
\text { Concealment of allocation: DONE } \\
\text { Follow-up of patients: } 7 \text { to } 10 \text { days and } 3 \text { months } \\
\text { Blinded assessment of outcomes: NOT DONE } \\
\text { Baseline measurement: DONE } \\
\text { Reliable primary outcome measure: DONE } \\
\text { Protection against contamination: DONE }\end{array}$} \\
\hline Participants & \multicolumn{2}{|c|}{$\begin{array}{l}\text { Location: UK } \\
\text { Patients recovering from a stroke } \\
\text { Median age: } 73 \\
\text { Treatment }=46 \\
\text { Control }=46\end{array}$} \\
\hline Interventions & \multicolumn{2}{|c|}{$\begin{array}{l}\text { Hospital at home (early discharge) } \\
\text { Type of service: community based stroke team that provided an inreach service to } 3 \text { local } \\
\text { acute hospitals, visiting patients prior to discharge. Multi-disciplinary team of occupational } \\
\text { therapist, physiotherpist, speech and language therapist, social worker. Nursing provided } \\
\text { by the primary care team. GP had clinical responsibility, with support from a consultant } \\
\text { working in stroke medicine. The stroke team used a key worker approach and patients held } \\
\text { a copy of their record which they or their carer could add to. Review meetings involved } \\
\text { patients and carers in their homes. Care available } 24 \text { hours a day if required } \\
\text { Control group: in-patient hospital care }\end{array}$} \\
\hline Outcomes & \multicolumn{2}{|c|}{$\begin{array}{l}\text { Quality of life } \\
\text { Functional status } \\
\text { Psychological well being } \\
\text { Carer well-being } \\
\text { Re-admission rate } \\
\text { Place of discharge }\end{array}$} \\
\hline \multicolumn{3}{|l|}{ Notes } \\
\hline \multicolumn{3}{|l|}{ Risk of bias } \\
\hline Bias & Authors' judgement & Support for judgement \\
\hline Allocation concealment (selection bias) & Low risk & A - Adequate \\
\hline
\end{tabular}


Ruckley 1978

\begin{tabular}{|c|c|c|}
\hline Methods & \multicolumn{2}{|c|}{$\begin{array}{l}\text { RCT } \\
\text { Concealment of allocation: DONE (sealed envelopes) } \\
\text { Blinded assessment of primary outcomes: NOT DONE } \\
\text { Follow-up of patients: DONE ( } 24 \text { hours, } 1 \text { week, } 2 \text { to } 3 \text { weeks) } \\
\text { Baseline measurement: DONE } \\
\text { Reliable primary outcome measures: DONE } \\
\text { Protection against contamination: NOT DONE }\end{array}$} \\
\hline Participants & \multicolumn{2}{|c|}{$\begin{array}{l}\text { Location: UK } \\
\text { Patients following elective surgery (hernia and varicose veins) } \\
\text { Average age: } 43 \text { years } \\
\text { Number of patients in } 33 \text { months: treatment }=117 \text {; control }=121 \text {; convalescent }=122\end{array}$} \\
\hline Interventions & \multicolumn{2}{|c|}{$\begin{array}{l}\text { Hospital at home } \\
\text { Type of service: organised by the hospital, provided by the community; } \\
\text { clinical responsibility held by the GP } \\
\text { Skill mix of HAH team: } 15 \text { GPs; district nurses } \\
\text { Control group: in-patient hospital care }\end{array}$} \\
\hline Outcomes & \multicolumn{2}{|c|}{$\begin{array}{l}\text { Clinical complications } \\
\text { Patient satisfaction } \\
\text { Re-admission to hospital } \\
\text { Carer satisfaction }\end{array}$} \\
\hline \multicolumn{3}{|l|}{ Notes } \\
\hline \multicolumn{3}{|l|}{ Risk of bias } \\
\hline Bias & Authors' judgement & Support for judgement \\
\hline Allocation concealment (selection bias) & Unclear risk & B - Unclear \\
\hline
\end{tabular}

\section{Rudd 1997}

\begin{tabular}{ll}
\hline Methods & RCT \\
Concealment of allocation: DONE & Follow up of patients: 1 year \\
Blinded assessment of outcomes: NOT DONE \\
Follow- up of patients: 2 , 4 and 6 months and 1 year \\
Baseline measurement: DONE \\
Reliable primary outcome measure: DONE \\
Protection against contamination: DONE \\
\hline Location: London, UK \\
Patients recovering from a stroke \\
Mean age: treatment $=70$ (SD 11); control = 72 (SD 12) \\
Treatment $=167$ \\
Control = 164
\end{tabular}


Rudd 1997 (Continued)

\begin{tabular}{|c|c|c|}
\hline Interventions & \multicolumn{2}{|c|}{$\begin{array}{l}\text { Hospital at home (early discharge) } \\
\text { Type of service: co-ordinated by hospital based consultant, community based nursing and } \\
\text { therapy; } 24 \text { hour care not available } \\
\text { Control group: hospital care and hospital organised rehabilitation }\end{array}$} \\
\hline Outcomes & \multicolumn{2}{|l|}{$\begin{array}{l}\text { Mortality } \\
\text { Re-admission } \\
\text { Functional status } \\
\text { Psychological well-being } \\
\text { Patient satisfaction } \\
\text { Carer satisfaction } \\
\text { Carer burden }\end{array}$} \\
\hline \multicolumn{3}{|l|}{ Notes } \\
\hline \multicolumn{3}{|l|}{ Risk of bias } \\
\hline Bias & Authors' judgement & Support for judgement \\
\hline Allocation concealment (selection bias) & Low risk & A - Adequate \\
\hline
\end{tabular}

\section{Shepperd 1998}

\begin{tabular}{ll}
\hline Methods & RCT \\
Concealment of allocation: DONE & Follow up of patients: 3 months \\
Blinded assessment of outcomes: NO \\
Baseline measurement: DONE \\
Reliable primary outcome measure: DONE \\
Protection against contamination: DONE
\end{tabular}


Shepperd 1998 (Continued)

\begin{tabular}{|c|c|c|}
\hline Outcomes & $\begin{array}{l}\text { Mortality } \\
\text { Re-admission } \\
\text { Functional status } \\
\text { Psychological well-being } \\
\text { Quality of life } \\
\text { Patient satisfaction } \\
\text { Carer satisfaction } \\
\text { Carer burden } \\
\text { Resource use and cost }\end{array}$ & \\
\hline \multicolumn{3}{|l|}{ Notes } \\
\hline \multicolumn{3}{|l|}{ Risk of bias } \\
\hline Bias & Authors' judgement & Support for judgement \\
\hline Allocation concealment (selection bias) & Low risk & A - Adequate \\
\hline
\end{tabular}

Skwarska 2000

\begin{tabular}{ll}
\hline Methods & RCT \\
Concealment of allocation: NOT CLEAR \\
Follow up of patients: 2 months \\
Blinded assessment of outcomes: NOT DONE \\
Baseline measurement: DONE \\
Reliable primary outcome measure: DONE \\
Protection against contamination: DONE
\end{tabular}

Risk of bias

Hospital at home early discharge (Review)

Copyright $(201$ I The Cochrane Collaboration. Published by John Wiley \& Sons, Ltd. 
Skwarska 2000 (Continued)

\begin{tabular}{lll}
\hline Bias & Authors' judgement & Support for judgement \\
\hline Allocation concealment (selection bias) & Unclear risk & B - Unclear \\
\hline
\end{tabular}

Suwenwela 2001

\begin{tabular}{|c|c|c|}
\hline Methods & \multicolumn{2}{|c|}{$\begin{array}{l}\text { RCT } \\
\text { Concealment of allocation: NOT CLEAR } \\
\text { Blinded assessment of outcomes: NOT DONE } \\
\text { Follow-up of patients: } 6 \text { months } \\
\text { Baseline measurement: DONE } \\
\text { Reliable primary outcome measure: DONE } \\
\text { Protection against contamination: DONE }\end{array}$} \\
\hline Participants & \multicolumn{2}{|c|}{$\begin{array}{l}\text { Location: Thailand } \\
\text { Recovering from a stroke } \\
\text { Mean age: } 59 \text { years } \\
\text { Treatment }=52 \\
\text { Control }=50\end{array}$} \\
\hline Interventions & \multicolumn{2}{|c|}{$\begin{array}{l}\text { Type of service: community based early discharge service, run by Red Cross volunteers; } \\
\text { family members were trained to give injections under nurse guidance while the patient was } \\
\text { in hospital, and encouraged to participate in physical and occupational therapy so they } \\
\text { could help with home rehabilitation } \\
\text { Control group: in-patient hospital care }\end{array}$} \\
\hline Outcomes & \multicolumn{2}{|l|}{$\begin{array}{l}\text { Mortality } \\
\text { Functional status } \\
\text { Satisfaction }\end{array}$} \\
\hline \multicolumn{3}{|l|}{ Notes } \\
\hline \multicolumn{3}{|l|}{ Risk of bias } \\
\hline Bias & Authors' judgement & Support for judgement \\
\hline Allocation concealment (selection bias) & Unclear risk & B - Unclear \\
\hline
\end{tabular}


Widen-Holmqvist 1998

\begin{tabular}{|c|c|c|}
\hline Methods & \multicolumn{2}{|c|}{$\begin{array}{l}\text { RCT } \\
\text { Concealment of allocation: DONE } \\
\text { Follow up of patients: } 3 \text { and } 6 \text { months } \\
\text { Blinded assessment of outcomes: NOT CLEAR } \\
\text { Baseline measurement: DONE } \\
\text { Reliable primary outcome measure: DONE } \\
\text { Protection against contamination: DONE }\end{array}$} \\
\hline Participants & \multicolumn{2}{|c|}{$\begin{array}{l}\text { Location: Stockholm, Sweden } \\
\text { Patients recovering from a stroke } \\
\text { Mean age: } 72 \text { years } \\
\text { Treatment }=41 \\
\text { Control }=40\end{array}$} \\
\hline Interventions & \multicolumn{2}{|c|}{$\begin{array}{l}\text { Hospital at home } \\
\text { Type of service: community based nursing and therapy } \\
\text { Control group: in-patient hospital care }\end{array}$} \\
\hline Outcomes & \multicolumn{2}{|c|}{$\begin{array}{l}\text { Functional status } \\
\text { Psychological well-being } \\
\text { Patient satisfaction } \\
\text { Use of hospital and home rehabilitation service }\end{array}$} \\
\hline \multicolumn{3}{|l|}{ Notes } \\
\hline \multicolumn{3}{|l|}{ Risk of bias } \\
\hline Bias & Authors' judgement & Support for judgement \\
\hline Allocation concealment (selection bias) & Low risk & A - Adequate \\
\hline
\end{tabular}

$\mathrm{GP}=$ general practitioner

$\mathrm{HAH}=$ hospital at home

$\mathrm{RCT}=$ randomised controlled trial

Characteristics of excluded studies [ordered by study ID]

\begin{tabular}{ll}
\hline Study & Reason for exclusion \\
\hline Bonnema 1998 & $\begin{array}{l}\text { RCT } \\
\text { This study evaluated early discharge from hospital of women following surgery for breast cancer; no hospital at } \\
\text { home was provided }\end{array}$ \\
\hline Brooten 1994 & $\begin{array}{l}\text { RCT } \\
\text { Obstetrics (this group of patients was not included in the review) }\end{array}$ \\
\hline
\end{tabular}


(Continued)

\begin{tabular}{ll} 
Bundred 1998 & $\begin{array}{l}\text { RCT } \\
\text { This study evaluated early discharge from hospital of women following surgery for breast cancer; no hospital at } \\
\text { home was provided }\end{array}$ \\
\hline Cummings 1991 & $\begin{array}{l}\text { Review } \\
\text { Review of home care as a substitute for nursing home care }\end{array}$ \\
\hline Farnworth 1994 & Non randomised study design \\
\hline Gerson 1976 & $\begin{array}{l}\text { RCT } \\
\text { No standard measures of outcome used. A physician, not blind to the patients' group assignment, assessed clinical } \\
\text { function. No criteria were used to define an untoward event. No intention to treat analysis, data were analysed } \\
\text { by the care the patient received }\end{array}$ \\
\hline
\end{tabular}

Hansen 1992 RCT

This study did not evaluate hospital at home, but a model for follow-up visits at home after discharge from hospital

Hedrick 1986 Review

This review examined the different types of home care that are provided

Hernandez 2003 RCT

$39 \%$ of those allocated to hospital care were not admitted to hospital, therefore the degree to which the intervention substituted for hospital care is not clear

Hill 1978 RCT

This study evaluated hospital at home care for patients with a myocardial infarction. Managing this group of patients totally at home is now obsolete as thrombolytic therapy has made admission to hospital necessary

\begin{tabular}{ll}
\hline Klettke 1999 & Cross over design \\
\hline Koopman 1996 & $\begin{array}{l}\text { RCT } \\
\text { This study compared patients treated with intravenous standard heparin administered in hospital with fixed dose } \\
\text { subcutaneous low-molecular weight heparin administered at home, when feasible. Patients were taught to self- } \\
\text { administer the low molecular weight heparin. Care was not provided in the patients homes by a team of health } \\
\text { care professionals; the intervention was not therefore considered hospital at home }\end{array}$ \\
\hline
\end{tabular}

Levine 1996 RCT

This study compared the use of intravenous standard heparin administered in the hospital with the administration of subcutaneous low molecular weight heparin primarily at home. The study nurse taught the patient to administer the medication. Care was not provided in the patients' homes by a team of health care professionals; the intervention was not therefore considered hospital at home

Magid 1989 RCT

This trial recruited 22 patients to compare the acceptance of in-patient with home continuous intravenous infusion of chemotherapy. While in hospital patients were instructed on the use of the infusors before discharge. The infusion was delivered in a continuous flow over 24 hours and new defusers were attached by the patient. Care was not provided in the patients' homes by a team of health care professionals. The intervention was not 
(Continued)

therefore considered hospital at home as no additional services were provided

\begin{tabular}{|c|c|}
\hline Mather 1976 & $\begin{array}{l}\text { RCT } \\
\text { This study evaluated hospital at home care for patients with a myocardial infarction. Managing this group of } \\
\text { patients totally at home is now obsolete as thrombolytic therapy has made admission to hospital necessary }\end{array}$ \\
\hline Melin 1992 & $\begin{array}{l}\text { RCT } \\
\text { Recruited patients with long term care needs. Hospital at home was a substitute for long term care }\end{array}$ \\
\hline Melin 1993 & $\begin{array}{l}\text { RCT } \\
\text { Recruited patients with long term care needs. Hospital at home was a substitute for long term care }\end{array}$ \\
\hline Romano 1991 & $\begin{array}{l}\text { RCT } \\
\text { Compares therapies at home, no comparison with hospital care }\end{array}$ \\
\hline Ronning 1998 & $\begin{array}{l}\text { RCT } \\
\text { In-patient hospital rehabilitation compared with rehabilitation provided by the municipalities in a variety of } \\
\text { settings which included nursing home rehabilitation on an in patient or out-patient basis, and further ambulatory } \\
\text { rehabilitation by a visiting physical therapist, speech therapist and/or nurse. Primary care also provided }\end{array}$ \\
\hline Stone 1968 & $\begin{array}{l}\text { CCT } \\
\text { A controlled trial -control patients were selected to match the home care patients }\end{array}$ \\
\hline Wade 1985 & $\begin{array}{l}\text { CCT } \\
\text { Compared two districts - one with a domiciliary stroke service and one without }\end{array}$ \\
\hline Williams 1981 & $\begin{array}{l}\text { RCT } \\
\text { Patients were randomly allocated to } 24 \text { hour bed rest in hospital or mobilisation at home following intra-articular } \\
\text { irradiation of the knee with yttrium- } 90 \text {. No additional services were provided at home }\end{array}$ \\
\hline Wolter 2004 & $\begin{array}{l}\text { RCT } \\
\text { Intravenous therapy, analysis based on number of readmissions, data not provided on number of people readmitted. } \\
\text { Authors contacted, no reply }\end{array}$ \\
\hline Zimmer 1984 & $\begin{array}{l}\text { RCT } \\
\text { Evaluated the effectiveness of a home care programme for home bound chronically ill patients. The home care } \\
\text { programme was not a substitute for in-patient hospital care, but an addition to existing community services }\end{array}$ \\
\hline Zimmer 1985 & $\begin{array}{l}\text { RCT } \\
\text { Evaluated the effectiveness of a home care programme for home bound chronically ill patients. The home care } \\
\text { programme was not a substitute for in-patient hospital care, but an addition to existing community services }\end{array}$ \\
\hline
\end{tabular}

CCT $=$ controlled clinical trial

$\mathrm{RCT}=$ randomised controlled trial 
DATA AND ANALYSES

Comparison 1. Hospital at home versus in-patient care

\begin{tabular}{|c|c|c|c|}
\hline Outcome or subgroup title & $\begin{array}{lc}\text { No. of } & \text { No. of } \\
\text { studies } & \text { participants }\end{array}$ & Statistical method & Effect size \\
\hline $\begin{array}{l}1 \text { Published data for older patients } \\
\text { with a mix of conditions and } \\
\text { those recovering from a stroke }\end{array}$ & & Other data & No numeric data \\
\hline $\begin{array}{l}\text { 1.1 Patient outcomes: } \\
\text { mortality at } 6 \text { weeks, not } \\
\text { included in meta-analysis }\end{array}$ & & Other data & No numeric data \\
\hline $\begin{array}{l}1.2 \text { Patient outcomes: } \\
\text { functional status - elderly with } \\
\text { a medical condition, including } \\
\text { COPD }\end{array}$ & & Other data & No numeric data \\
\hline $\begin{array}{l}\text { 1.3 Patient outcomes: } \\
\text { functional status/general health } \\
\text { - recovering from a stroke }\end{array}$ & & Other data & No numeric data \\
\hline $\begin{array}{l}\text { 1.4 Patient outcomes: quality } \\
\text { of life - older people with a mix } \\
\text { of conditions }\end{array}$ & & Other data & No numeric data \\
\hline $\begin{array}{l}\text { 1.5 Patient outcomes: quality } \\
\text { of life COPD }\end{array}$ & & Other data & No numeric data \\
\hline $\begin{array}{l}\text { 1.6 Patient outcomes: quality } \\
\text { of life/health status - those } \\
\text { recovering from a stroke }\end{array}$ & & Other data & No numeric data \\
\hline 1.7 Cognitive ability & & Other data & No numeric data \\
\hline $\begin{array}{l}\text { 1.8 Patient outcomes: } \\
\text { psychological well-being - older } \\
\text { people with a mix of conditions }\end{array}$ & & Other data & No numeric data \\
\hline $\begin{array}{l}\text { 1.9 Patient outcomes: } \\
\text { psychological well-being - those } \\
\text { recovering from a stroke }\end{array}$ & & Other data & No numeric data \\
\hline $\begin{array}{l}\text { 1.10 Patient satisfaction } \\
\text { and preference for place of } \\
\text { care - elderly with a medical } \\
\text { condition including COPD }\end{array}$ & & Other data & No numeric data \\
\hline $\begin{array}{l}1.11 \text { Patient satisfaction and } \\
\text { preference for place of care - } \\
\text { recovering from a stroke }\end{array}$ & & Other data & No numeric data \\
\hline 1.12 Carer outcomes & & Other data & No numeric data \\
\hline 1.13 GP views & & Other data & No numeric data \\
\hline $\begin{array}{l}1.14 \text { Readmission to hospital } \\
\text { - short and long-term (not } \\
\text { included in the meta- analysis) }\end{array}$ & & Other data & No numeric data \\
\hline $\begin{array}{l}1.15 \text { Length of stay: in-patient } \\
\text { days (including readmission } \\
\text { days) - recovering from a stroke }\end{array}$ & & Other data & No numeric data \\
\hline
\end{tabular}


1.16 Hospital length of stay elderly medical

1.18 Cost

1.19 Use of other services

- elderly with a medical

condition

1.20 Use of other services -

recovering from a stroke

1.21 Patients' place of

residence at follow up

1.22 Hospital at home length

of stay

1.23 Total length of stay -

hospital plus hospital at home 1.24 Falls

2 Mortality at 3 months - older people with a mix of conditions

2.1 Mortality at 3 months older people with a mix of conditions

3 Mortality at 6 months older people with a medical condition requiring geriatric rehabilitation

4 Mortality at 3 months - patients recovering from a stroke

5 Mortality at 6 months - patients recovering from a stroke

5.1 Mortality at 6 months patients recovering from a stroke

6 Mortality at 1 year - patients recovering from a stroke

7 Mortality - chronic obstructive airways disease

7.1 Mortality at 2 to 3 months chronic obstructive airways disease

8 Readmission to hospital at 3 months - older people with a mix of conditions

8.1 Re admission to hospital - older people with a mix of conditions

9 Readmissions at 3 months those recovering from a stroke 9.1 Re admission to hospital for patients recovering from a stroke at 3 months follow-up

10 Readmissions at 6 months those recovering from a stroke
Other data

No numeric data

Other data

No numeric data

Other data

No numeric data

Other data

No numeric data

Other data

No numeric data

Other data

No numeric data

Other data

No numeric data

No numeric data $1.12[0.77,1.63]$

Other data

1084

Risk Ratio (M-H, Fixed, 95\% CI)

$1.12[0.77,1.63]$

$1.04[0.47,2.31]$

Risk Ratio (M-H, Fixed, 95\% CI)

$1.05[0.48,2.34]$

$0.83[0.47,1.44]$

$0.83[0.47,1.44]$

$0.96[0.65,1.42]$

$0.50[0.23,1.09]$

$0.50[0.23,1.09]$

$1.35[1.03,1.76]$

$1.35[1.03,1.76]$

$1.06[0.47,2.38]$

$1.06[0.47,2.38]$

$1.00[0.63,1.60]$

3232 Risk Ratio (M-H, Fixed, 95\% CI)

Hospital at home early discharge (Review)

Copyright () 201 I The Cochrane Collaboration. Published by John Wiley \& Sons, Ltd. 
10.1 Readmission at 6 months - those recovering from a stroke

11 Readmission at 1 year for those recovering from a stroke

12 Readmission for those with COPD

12.1 Readmission to hospital at 3 months - patients with COPD

13 Functional ability at 3 months - older people with a mix of conditions

14 Residential care at 1 year follow up (Donald 6 months) - older patients with a mix of conditions

15 Residential care at 6 months follow up (Rodgers 3 month data) - recovering from a stroke

16 Hospital length of stay - older people with a mix of conditions

17 Hospital length of stay - those recovering from a stroke

18 Hospital length of stay - patients with chronic obstructive pulmonary disease

18.1 Chronic obstructive airways disease

19 Total length of stay - older people with a mix of mainly medical conditions

20 Early discharge of patients following surgery

20.1 Patient outcomes: all clinical complications

20.2 Patient outcomes:

mortality

20.3 Patient outcomes:

functional status

20.4 Patient outcomes: quality of life

20.5 Patient outcomes: patient satisfaction

20.6 Carer outcomes

20.7 GP workload

20.8 Readmission to hospital

20.9 Cost

20.10 Length of stay

20.11 Carer satisfaction

21 Hospital length of stay - older people recovering from surgery
Other data

No numeric data

Other data

No numeric data

Other data

No numeric data

Other data

Other data

No numeric data

No numeric data

Other data

Other data

Other data

Other data

Other data

Other data

Other data
No numeric data

No numeric data No numeric data No numeric data No numeric data No numeric data No numeric data $-4.44[-6.37,-2.51]$ 


\begin{tabular}{|c|c|c|c|}
\hline $\begin{array}{l}22 \text { Total length of stay - older } \\
\text { people having elective surgery }\end{array}$ & 245 & Mean Difference (IV, Fixed, 95\% CI) & $2.79[0.77,4.81]$ \\
\hline $\begin{array}{l}23 \text { Readmission to hospital - } \\
\text { surgery }\end{array}$ & 2 & Risk Ratio (M-H, Fixed, 95\% CI) & Totals not selected \\
\hline 23.1 Hip replacement & 1 & Risk Ratio (M-H, Fixed, 95\% CI) & $0.0[0.0,0.0]$ \\
\hline 23.2 Knee replacement & 1 & Risk Ratio (M-H, Fixed, 95\% CI) & $0.0[0.0,0.0]$ \\
\hline 23.3 Hernia or varicose veins & 1 & Risk Ratio (M-H, Fixed, 95\% CI) & $0.0[0.0,0.0]$ \\
\hline 23.4 Hysterectomy & 1 & Risk Ratio (M-H, Fixed, 95\% CI) & $0.0[0.0,0.0]$ \\
\hline
\end{tabular}

\section{Comparison 2. IPD data analysis}

\begin{tabular}{|c|c|c|c|c|}
\hline Outcome or subgroup title & $\begin{array}{l}\text { No. of } \\
\text { studies }\end{array}$ & $\begin{array}{c}\text { No. of } \\
\text { participants }\end{array}$ & Statistical method & Effect size \\
\hline $\begin{array}{l}1 \text { IPD generic inverse variance } \\
\text { early discharge elderly medical } \\
\text { mortality at } 3 \text { months }\end{array}$ & 5 & 978 & Mortality (Fixed, 95\% CI) & $1.04[0.68,1.58]$ \\
\hline $\begin{array}{l}\text { 1.1 Mortality at } 3 \text { months } \\
\text { in older patients with a mix } \\
\text { of conditions (Martin at } 6 \\
\text { months) }\end{array}$ & 5 & 978 & Mortality (Fixed, 95\% CI) & $1.04[0.68,1.58]$ \\
\hline $\begin{array}{l}2 \text { IPD generic inverse variance } \\
\text { early discharge readmission at } 3 \\
\text { months }\end{array}$ & 3 & 705 & Readmission (Fixed, 95\% CI) & $1.52[1.07,2.16]$ \\
\hline $\begin{array}{l}3 \text { IPD stroke mortality at } 3 \\
\text { to } 6 \text { months - Manchester, } \\
\text { Anderson, Cunliffe, Shepperd } \\
3 \text { months }\end{array}$ & 7 & 494 & Mortality (Fixed, 95\% CI) & $0.86[0.35,2.07]$ \\
\hline 4 Stroke Barthel at 3 months & 2 & 174 & Std. Mean Difference (IV, Fixed, 95\% CI) & $0.11[-0.19,0.40]$ \\
\hline 5 Stroke Barthel at 6 months & 2 & 185 & Std. Mean Difference (IV, Fixed, 95\% CI) & $0.01[-0.28,0.30]$ \\
\hline $\begin{array}{l}6 \text { Sensitivity analysis in favour of } \\
\text { HAH }\end{array}$ & 5 & 978 & Mortality (Fixed, 95\% CI) & $1.03[0.67,1.56]$ \\
\hline $\begin{array}{l}\text { 6.1 Sensitivity analysis } \\
\text { changing follow-up time of } \\
\text { Richards trial in favour of } \\
\text { HAH }\end{array}$ & 5 & 978 & Mortality (Fixed, 95\% CI) & $1.03[0.67,1.56]$ \\
\hline $\begin{array}{l}7 \text { Sensitivity analysis in favour of } \\
\text { hospital }\end{array}$ & 5 & 978 & Mortality (Fixed, 95\% CI) & $1.04[0.69,1.59]$ \\
\hline $\begin{array}{l}\text { 7.1 Sensitivity analysis } \\
\text { changing follow-up time of } \\
\text { Richards trial in favour of } \\
\text { hospital }\end{array}$ & 5 & 978 & Mortality (Fixed, 95\% CI) & $1.04[0.69,1.59]$ \\
\hline $\begin{array}{l}8 \text { Sensitivity analysis removing } \\
\text { readmissions in the first } 14 \text { days }\end{array}$ & 3 & 705 & Readmission (Fixed, 95\% CI) & $1.34[0.91,1.98]$ \\
\hline 9 Readmission stroke & 1 & & Readmission (Fixed, 95\% CI) & $1.62[0.58,4.55]$ \\
\hline
\end{tabular}


Comparison 3. IPD adjusted for age only

\begin{tabular}{|c|c|c|c|c|}
\hline Outcome or subgroup title & $\begin{array}{l}\text { No. of } \\
\text { studies }\end{array}$ & $\begin{array}{c}\text { No. of } \\
\text { participants }\end{array}$ & Statistical method & Effect size \\
\hline $\begin{array}{l}1 \text { IPD generic inverse variance } \\
\text { early discharge elderly medical } \\
\text { mortality at } 3 \text { months }\end{array}$ & 4 & 608 & Mortality (Fixed, 95\% CI) & $1.13[0.66,1.94]$ \\
\hline $\begin{array}{l}\text { 1.1 Mortality in elderly } \\
\text { medical patients at } 3 \text { months }\end{array}$ & 4 & 608 & Mortality (Fixed, 95\% CI) & $1.13[0.66,1.94]$ \\
\hline $\begin{array}{l}2 \text { IPD mortality at } 3 \text { to } 6 \text { months } \\
\text { (Manchester, Anderson } \& \\
\text { Shepperd at } 3 \text { months) }\end{array}$ & 6 & 407 & Mortality (Fixed, 95\% CI) & $0.69[0.26,1.81]$ \\
\hline $\begin{array}{l}3 \text { IPD generic inverse variance } \\
\text { early discharge readmission at } 3 \\
\text { months }\end{array}$ & 2 & 335 & Readmission (Fixed, 95\% CI) & $2.47[1.27,4.78]$ \\
\hline 4 Stroke Barthel at 3 months & 2 & 174 & Std. Mean Difference (IV, Fixed, 95\% CI) & $0.12[-0.18,0.42]$ \\
\hline 5 Stroke Barthel at 6 monhts & 2 & 185 & Std. Mean Difference (IV, Fixed, 95\% CI) & $0.00[-0.29,0.29]$ \\
\hline $\begin{array}{l}6 \text { Sensitivity analysis mortality in } \\
\text { favour of HAH }\end{array}$ & 3 & 554 & Mortality (Fixed, 95\% CI) & $1.14[0.64,2.02]$ \\
\hline $\begin{array}{l}\text { 6.1 Sensitivity analysis } \\
\text { changing follow-up time of } \\
\text { Richards trial in favour of } \\
\text { HAH }\end{array}$ & 3 & 554 & Mortality (Fixed, 95\% CI) & $1.14[0.64,2.02]$ \\
\hline $\begin{array}{l}7 \text { Sensitivity analysis mortality in } \\
\text { favour of hospital }\end{array}$ & 3 & 554 & Mortality (Fixed, 95\% CI) & $1.18[0.66,2.09]$ \\
\hline $\begin{array}{l}\text { 7.1 Sensitivity analysis } \\
\text { changing follow-up time of } \\
\text { Richards trial in favour of } \\
\text { hospital }\end{array}$ & 3 & 554 & Mortality (Fixed, 95\% CI) & $1.18[0.66,2.09]$ \\
\hline
\end{tabular}

Comparison 4. IPD adjusted for age and sex

\begin{tabular}{|c|c|c|c|c|}
\hline Outcome or subgroup title & $\begin{array}{l}\text { No. of } \\
\text { studies }\end{array}$ & $\begin{array}{c}\text { No. of } \\
\text { participants }\end{array}$ & Statistical method & Effect size \\
\hline $\begin{array}{l}1 \text { IPD generic inverse variance } \\
\text { early discharge elderly medical } \\
\text { mortality at } 3 \text { months }\end{array}$ & 5 & 978 & Mortality (Fixed, 95\% CI) & $1.06[0.69,1.61]$ \\
\hline $\begin{array}{l}1.1 \text { Mortality in elderly } \\
\text { medical patients at } 3 \text { months }\end{array}$ & 5 & 978 & Mortality (Fixed, 95\% CI) & $1.06[0.69,1.61]$ \\
\hline $\begin{array}{l}2 \text { IPD stroke mortality at } 3 \\
\text { to } 6 \text { months - Manchester, } \\
\text { Anderson, Cunliffe \& } \\
\text { Shepperd } 3 \text { months }\end{array}$ & 7 & 494 & Mortality (Fixed, 95\% CI) & $0.79[0.32,1.91]$ \\
\hline $\begin{array}{l}3 \text { IPD generic inverse variance } \\
\text { readmission elderly patients } \\
\text { with a mix of conditions }\end{array}$ & 3 & 705 & Readmission (Fixed, 95\% CI) & $1.57[1.10,2.24]$ \\
\hline
\end{tabular}

Hospital at home early discharge (Review)

Copyright (C) 20II The Cochrane Collaboration. Published by John Wiley \& Sons, Ltd. 
4 Stroke Barthel at 3 months

5 Stroke Barthel at 6 months

6 Sensitivity analysis mortality

elderly patients with a mix of

conditions in favour of $\mathrm{HAH}$

6.1 Sensitivity analysis

changing follow-up time of

Richards trial in favour of

$\mathrm{HAH}$

7 Sensitivity analysis mortality elderly patient with a mix of conditions in favour of hospital

7.1 Sensitivity analysis changing follow-up time of Richards trial in favour of hospital

8 Sensitivity analysis changing follow-up time for Donnelly trial in favour of $\mathrm{HAH}$

9 Sensitivity analysis changing follow-up time for Donnelly (stroke) in favour of hospital

10 Sensitivity analysis removing readmissions for elderly with a mix of conditions during first 14 days adjusted for age and sex

11 Readmission - recovering from a stroke
Std. Mean Difference (IV, Fixed, 95\% CI) Std. Mean Difference (IV, Fixed, 95\% CI)

$0.14[-0.16,0.43]$

$0.02[-0.27,0.30]$

$1.02[0.67,1.55]$

$1.02[0.67,1.55]$

$5978 \quad$ Mortality (Fixed, 95\% CI)

$1.04[0.68,1.59]$

Mortality (Fixed, 95\% CI)

$1.04[0.68,1.59]$

Mortality (Fixed, 95\% CI)

$0.62[0.23,1.61]$

Mortality (Fixed, 95\% CI)

$0.63[0.24,1.64]$

6

407

Mortality (Fixed, 95\% CI)

$1.32[0.89,1.96]$

Readmissions (Fixed, 95\% CI)

$1.84[0.64,5.34]$

\section{Analysis I.I. Comparison I Hospital at home versus in-patient care, Outcome I Published data for older patients with a mix of conditions and those recovering from a stroke.}

Published data for older patients with a mix of conditions and those recovering from a stroke

\begin{tabular}{l|l}
\hline Study & Results \\
\hline Patient outcomes: mortality at 6 weeks, not included in meta-analysis \\
\hline
\end{tabular}

\begin{tabular}{l|l|}
\hline Indredavik 2000 & $\begin{array}{l}\text { Mortality at } 6 \text { weeks: } \\
\text { Treatment } 4 / 160 \\
\text { Control } 7 / 160\end{array}$ \\
\hline Martin 1994 & $\begin{array}{l}\text { Mortality: } \\
\text { At } 6 \text { weeks: } \\
\text { treatment: } 2 / 29(6.9 \%) \\
\text { control: } 0 / 25(0 \%) \\
\text { observed difference: } 6.9 \% \\
95 \% \text { CI }-0.2 \% \text { to } 16 \%\end{array}$ \\
& $\begin{array}{l}\text { At } 12 \text { weeks: } \\
\text { treatment: } 3 / 29(10.3 \%) \\
\text { control: } 3 / 25(12 \%)\end{array}$ \\
\hline
\end{tabular}


Published data for older patients with a mix of conditions and those recovering from a stroke (Continued)

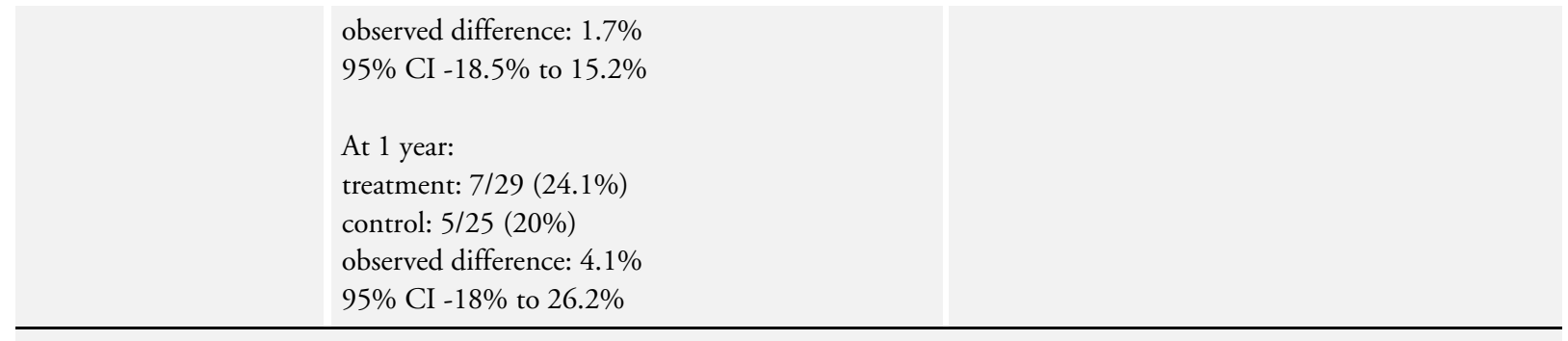

Patient outcomes: functional status - elderly with a medical condition, including COPD

\begin{tabular}{|c|c|}
\hline Caplan 2006 & $\begin{array}{l}\text { Functional independence measure (FIM) at enrol- } \\
\text { ment } \\
T=75.46 \text { (22.1) } \\
C=78.47 \text { (19.13) } \\
P=0.50 \\
\text { Baseline - start of rehabilitation phase post randomi- } \\
\text { sation } \\
T=100.31 \text { (16.94) } \\
C=78.94 \text { (16.01) } \\
P<0.0001 \text { (authors interpret as indication that inter- } \\
\text { vention group required additional days in the acute } \\
\text { ward in order to be more independent before going } \\
\text { home) } \\
\text { At } 1 \text { month, mean (sd) } \\
T=100.93 \text { (22.68) } \\
C=105.47 \text { (17.06) } \\
P=0.36 \\
\text { At } 6 \text { months, mean (sd) } \\
T=102.96 \text { (23.8) } \\
C=106.35 \text { (14.43) } \\
P 0.53\end{array}$ \\
\hline Cunliffe 2004 & $\begin{array}{l}\text { Barthel ( } 0 \text { to } 20) 0=\text { worse score } \\
\text { At } 3 \text { months } \\
\text { Mean difference } 1.2 \text { ( } 95 \% \text { CI } 0.4 \text { to } 1.9) \\
\text { At } 12 \text { months } \\
\text { Mean difference } 0.2 \text { ( } 95 \% \text { CI }-0.7 \text { to } 1.1 \text { ) } \\
\text { Extended ADL total ( } 0 \text { to } 66 \text { ) } 0=\text { worse score } \\
\text { At } 3 \text { months } \\
\text { Mean difference } 3.1 \text { ( } 95 \% \text { CI }-0.1 \text { to } 6.3 \text { ) } \\
\text { At } 12 \text { months } \\
\text { Mean difference } 3.0 \text { ( } 95 \% \text { CI }-0.4 \text { to } 6.5 \text { ) }\end{array}$ \\
\hline
\end{tabular}


Published data for older patients with a mix of conditions and those recovering from a stroke (Continued)

\begin{tabular}{|c|c|c|}
\hline & $\begin{array}{l}\text { Mobility ( } 0 \text { to } 18) \text { At } 3 \text { months } \\
\text { Mean difference } 0.3 \text { ( } 95 \% \text { CI }-0.8 \text { to } 1.4) \\
\text { At } 12 \text { months } \\
\text { Mean difference } 0.3 \text { ( } 95 \% \text { CI }-0.9 \text { to } 1.4) \\
\text { Kitchen ( } 0 \text { to } 15) \\
\text { At } 3 \text { months } \\
\text { Mean difference } 1.2 \text { ( } 95 \% \text { CI } 0.2 \text { to } 2.3 \text { ) } \\
\text { At } 12 \text { months } \\
\text { Mean difference } 0.7 \text { ( } 95 \% \text { CI }-0.4 \text { to } 1.8) \\
\text { Domestic ( } 0 \text { to } 15) \\
\text { At } 3 \text { months } \\
\text { Mean difference } 1.1 \text { ( } 95 \% \text { CI } 0.2 \text { to } 2.0) \\
\text { At } 12 \text { months } \\
\text { Mean difference } 1.4 \text { ( } 95 \% \text { CI } 0.4 \text { to } 2.4) \\
\text { Leisure (0 to } 18) \\
\text { At } 3 \text { months } \\
\text { Mean difference } 0.5 \text { ( } 95 \% \text { CI }-0.3 \text { to } 1.3 \text { ) } \\
\text { At } 12 \text { months } \\
\text { Mean difference } 0.6 \text { ( } 95 \% \text { CI }-0.3 \text { to } 1.5\end{array}$ & \\
\hline Donald 1995 & $\begin{array}{l}\text { Functional status: } \\
\text { At } 6 \text { months: } \\
\text { treatment mean: } 16.4(\mathrm{n}=21) \\
\text { control mean: } 15.0(\mathrm{n}=26)\end{array}$ & $\begin{array}{l}\text { Used the Barthel Score (a high score indicates inde- } \\
\text { pendence). } \\
\text { No p value given, insufficient data to calculate CI }\end{array}$ \\
\hline Harris 2005 & $\begin{array}{l}\text { Functional independence measure } 10 \text { day mean } \\
\text { change from baseline (sd) } \\
\mathrm{T}=6.36(13.68)[\mathrm{n}=134] \\
\mathrm{C}=8.73(14.79)[\mathrm{n}=134] \\
\text { Difference }-2.3795 \% \text { CI }-5.78,1.04 \\
30 \text { days mean change from baseline (sd) } \\
\mathrm{T}=11.29(13.16) \text { [n=126] } \\
\mathrm{C}=11.94(13.34)[\mathrm{n}=125] \\
\text { Difference }-0.6595 \% \text { CI }-3.93,2.63 \\
90 \text { day mean change from baseline (sd) } \\
\mathrm{T}=13.09 \text { (16.75) [n=124] } \\
\mathrm{C}=14.25 \text { (14.28) [n=122] } \\
\text { Difference }-1.1795 \% \text { CI-5.06, } 2.73 \\
\text { Functional independence measure - physical } 10 \text { day } \\
\text { mean change from baseline (sd) }\end{array}$ & \\
\hline
\end{tabular}


Published data for older patients with a mix of conditions and those recovering from a stroke (Continued)

\begin{tabular}{|c|c|c|}
\hline & $\begin{array}{l}\mathrm{T}=5.69(13.12)[\mathrm{n}=134] \\
\mathrm{C}=7.58(14.4)[\mathrm{n}=134] \\
\text { Difference }-1.8995 \% \text { CI }-5.19,1.41 \\
30 \text { days mean change from baseline }(\mathrm{sd}) \\
\mathrm{T}=10.75(12.56)[\mathrm{n}=126] \\
\mathrm{C}=11.19(12.73)[\mathrm{n}=125] \\
\text { Difference }-0.4495 \% \text { CI }-3.57,2.69 \\
90 \text { day mean change from baseline (sd) } \\
\mathrm{T}=12.6(14.98) \text { [n=124] } \\
\mathrm{C}=13.35(13.32)[\mathrm{n}=122] \\
\text { Difference }-0.7695 \% \text { CI- } 4.30,2.79 \\
\text { Instrumental activities of daily living } 10 \text { day mean } \\
\text { change from baseline (sd) } \\
\mathrm{T}=0.62(2.83) \text { [n=134] } \\
\mathrm{C}=0.96(2.97)[\mathrm{n}=134] \\
\text { Difference }-0.3495 \% \text { CI }-1.04,0.35 \\
30 \text { days mean change from baseline (sd) } \\
\mathrm{T}=2.01(2.95) \text { [n=126] } \\
\mathrm{C}=1.50(2.95) \text { [n=125] } \\
\text { Difference } 0.5195 \% \text { CI }-0.22,1.24 \\
90 \text { day mean change from baseline (sd) } \\
\mathrm{T}=2.69(3.31)[\mathrm{n}=214] \\
\mathrm{C}=2.5(3.47)[\mathrm{n}=123] \\
\text { Difference } 0.2095 \% \text { CI- } 0.65,1.04\end{array}$ & \\
\hline Martin 1994 & $\begin{array}{l}\text { Functional status: } \\
\text { At } 6 \text { weeks: } \\
\text { treatment median: } 16 \\
\text { control median: } 15 \\
\text { At } 12 \text { weeks: } \\
\text { treatment median: } 15 \\
\text { control median: } 15 \\
\text { At } 6 \text { weeks: } \\
\text { treatment median: } 13 \\
\text { control median: } 9 \\
\text { At } 12 \text { weeks: } \\
\text { treatment median: } 13 \\
\text { control median: } 9\end{array}$ & $\begin{array}{l}\text { The Barthel Index }(0-20) \\
\text { No p values given, insufficient data to calculate CI } \\
\text { The Rivermead Score }(9-27) \text { (a high score indicat- } \\
\text { ing a good outcome), a measure of domestic abili- } \\
\text { ties. } \\
\text { No p values given, insufficient data to calculate CI }\end{array}$ \\
\hline Ojoo 2002 & $\begin{array}{l}\text { Respiratory symptom score mean improvement: } \\
\text { treatment }(\mathrm{n}=30): 12.1(17.3) \\
\text { control }(\mathrm{n}=30): 11.6(12.8)\end{array}$ & St George's respiratory questionnaire \\
\hline
\end{tabular}


Published data for older patients with a mix of conditions and those recovering from a stroke (Continued)

\begin{tabular}{|c|c|c|}
\hline Richards 1998 & $\begin{array}{l}\text { Barthel, change from baseline to } 4 \text { weeks: } \\
T=1.5(2.93) \\
n=152 \\
C=1.0(2.82) \\
n=69 \\
\text { Baseline to } 3 \text { months } \\
T=1.9(3.22) \\
n=141 \\
C=1.7(2.68) \\
n=60\end{array}$ & Barthel Index \\
\hline Shepperd 1998 & $\begin{array}{l}\text { Elderly medical patients: } \\
\text { Mean value (SD) at baseline } \\
\mathrm{T}=14.74(4.82) \\
\mathrm{n}=47 \\
\text { Mean change from baseline to } 3 \text { months follow-up } \\
\mathrm{T}=-1.71 \\
\mathrm{n}=38 \\
\mathrm{C}=1.27 \\
\mathrm{n}=37 \\
\text { difference } 0.4495 \% \text { CI }-2.09 \text { to } 1.21 \\
\mathrm{C}=15.69(2.58) \\
\mathrm{n}=42\end{array}$ & $\begin{array}{l}\text { Barthel Index, scale } 0 \text { to } 20 \text { (low score=high depen- } \\
\text { dence) }\end{array}$ \\
\hline Skwarska 2000 & No data reported & Chronic Respiratory Questionnaire \\
\hline
\end{tabular}

Patient outcomes: functional status/general health - recovering from a stroke

\begin{tabular}{|c|c|}
\hline Anderson 2000 & $\begin{array}{l}\text { Modified Barthel Index at } 6 \text { months follow-up } \\
\text { Median (IQR) } \\
T=96.0 \text { ( } 88.3 \text { to } 100) \\
\mathrm{C}=98.0 \text { (85.5 to } 100) \\
\mathrm{P}=0.99 \\
\text { Median difference }-2.0,95 \% \text { CI }-2.0 \text { to } 2.0\end{array}$ \\
\hline Askim 2004 & $\begin{array}{l}\text { Modified Rankin Scale (score of }<2 \text { classified as } \\
\text { independent } \\
\text { At } 6 \text { weeks } \\
\mathrm{T}=16 / 31(52 \%) \\
\mathrm{C}=16 / 31(52 \%) \\
\mathrm{P}=1.0 \\
95 \% \mathrm{CI}-0.26 \text { to } 0.26 \\
\text { At } 26 \text { weeks post stroke } \\
\mathrm{T}=13 / 31(42 \%)\end{array}$ \\
\hline
\end{tabular}


Published data for older patients with a mix of conditions and those recovering from a stroke (Continued)

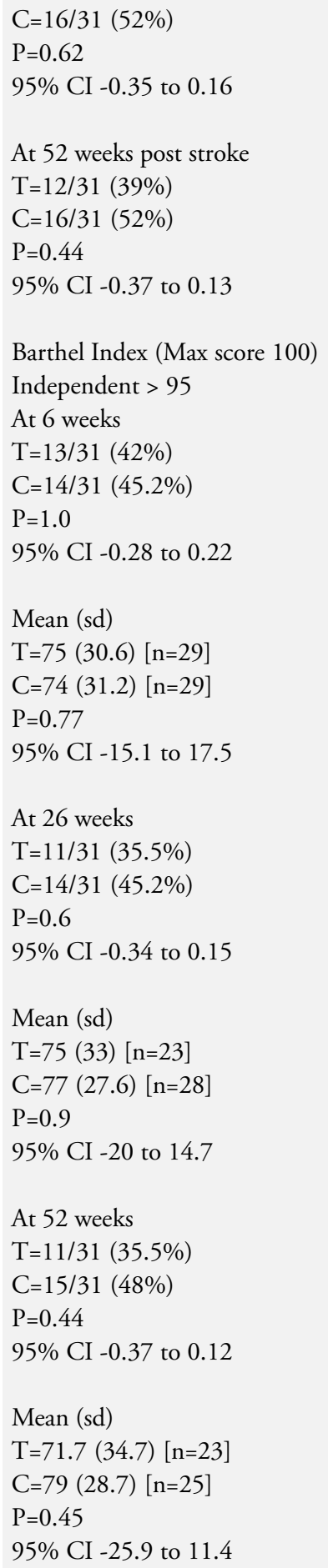


Published data for older patients with a mix of conditions and those recovering from a stroke (Continued)

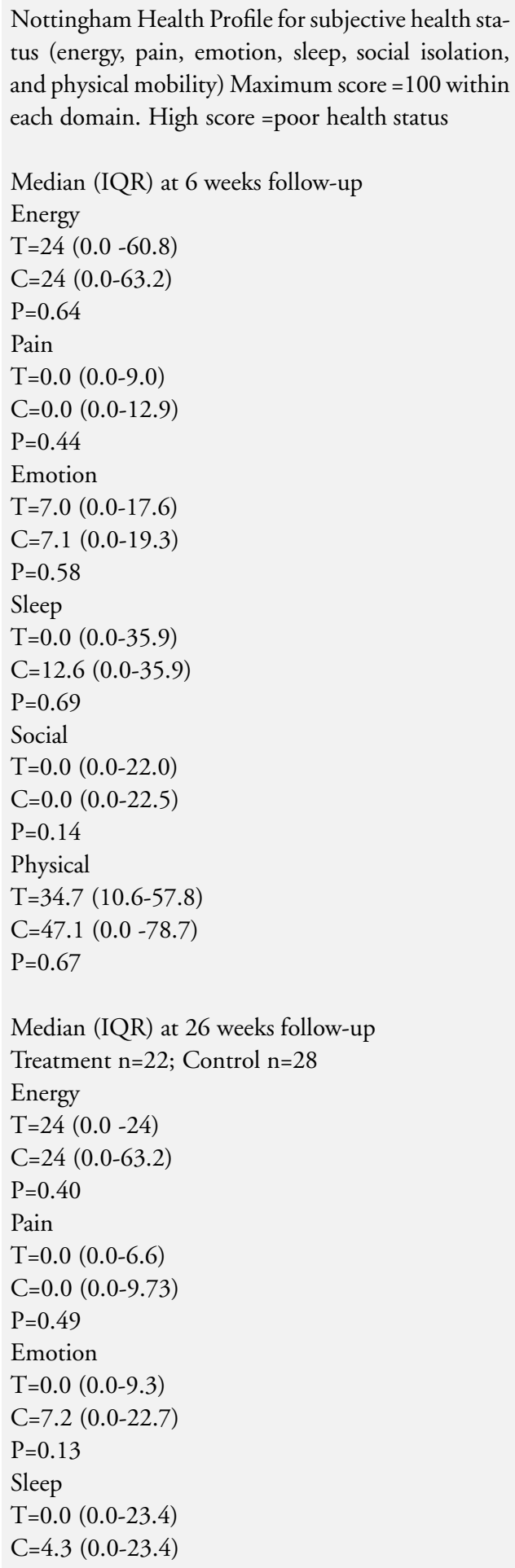


Published data for older patients with a mix of conditions and those recovering from a stroke (Continued)

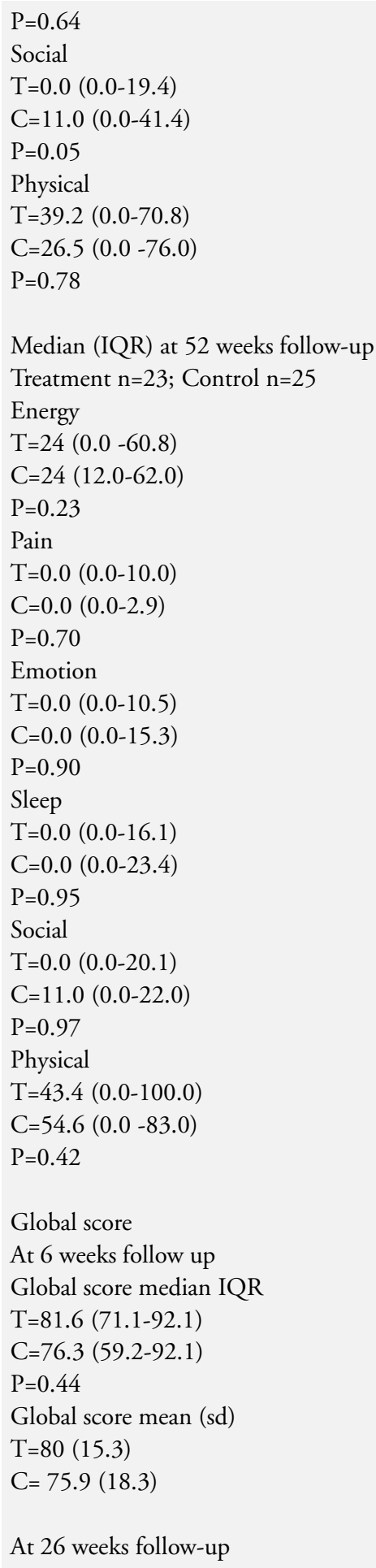


Published data for older patients with a mix of conditions and those recovering from a stroke (Continued)

\begin{tabular}{|c|c|}
\hline & $\begin{array}{l}\text { Global score median IQR } \\
\mathrm{T}=81.6(67.8-95.4) \\
\mathrm{C}=76.3(55.9-96.7) \\
\mathrm{P}=0.21 \\
\text { Global score mean }(\mathrm{sd}) \\
\mathrm{T}=82.5(13.7) \\
\mathrm{C}=75.8(19.5) \\
\text { At } 52 \text { weeks follow-up } \\
\text { Global score median IQR } \\
\mathrm{T}=79(68.4-97.4) \\
\mathrm{C}=81.6(68.4-96.1) \\
\mathrm{P}=0.92 \\
\mathrm{Global} \text { score mean }(\mathrm{sd}) \\
\mathrm{T}=79.8(16.8) \\
\mathrm{C}=79.8(17.7)\end{array}$ \\
\hline Bautz-Holter 2002 & $\begin{array}{l}\text { Nottingham extended ADL } \\
\text { Median (IQR)Mobility } \\
\text { At } 3 \text { months } \\
\mathrm{T}=10.5 \text { ( } 4 \text { to } 14) \\
\mathrm{C}=8 \text { ( } 3 \text { to } 15) \\
95 \% \text { CI of the difference }-2 \text { to } 4 \mathrm{p}=0.41 \\
\text { At } 6 \text { months } \\
\mathrm{T}=11 \text { ( } 6 \text { to } 14) \\
\mathrm{C}=10 \text { ( } 4 \text { to } 15) \\
95 \% \text { CI of the difference }-2 \text { to } 4 \mathrm{p}=0.55 \\
\text { Kitchen } \\
\text { At } 3 \text { months } \\
\mathrm{T}=12 \text { ( } 8 \text { to } 14) \\
\mathrm{C}=12 \text { ( } 6 \text { to } 15) \\
95 \% \text { CI of the difference }-2 \text { to } 1 \mathrm{p}=0.87 \\
\text { Kitchen } \\
\text { At } 6 \text { months } \\
\text { T=12 ( } 8 \text { to } 15) \\
\text { C }=13 \text { ( } 10 \text { to } 15) \\
95 \% \text { CI of the difference }-2 \text { to } 1 \mathrm{p}=0.52 \\
\text { Domestic } \\
\text { At } 3 \text { months } \\
\text { T }=6 \text { ( } 3 \text { to } 8) \\
\text { C }=5 \text { ( } 3 \text { to } 10) \\
95 \% \text { CI of the difference }-3 \text { to } 1 \mathrm{p}=0.58 \\
\text { Domestic } \\
\text { At } 6 \text { months }\end{array}$ \\
\hline
\end{tabular}


Published data for older patients with a mix of conditions and those recovering from a stroke (Continued)

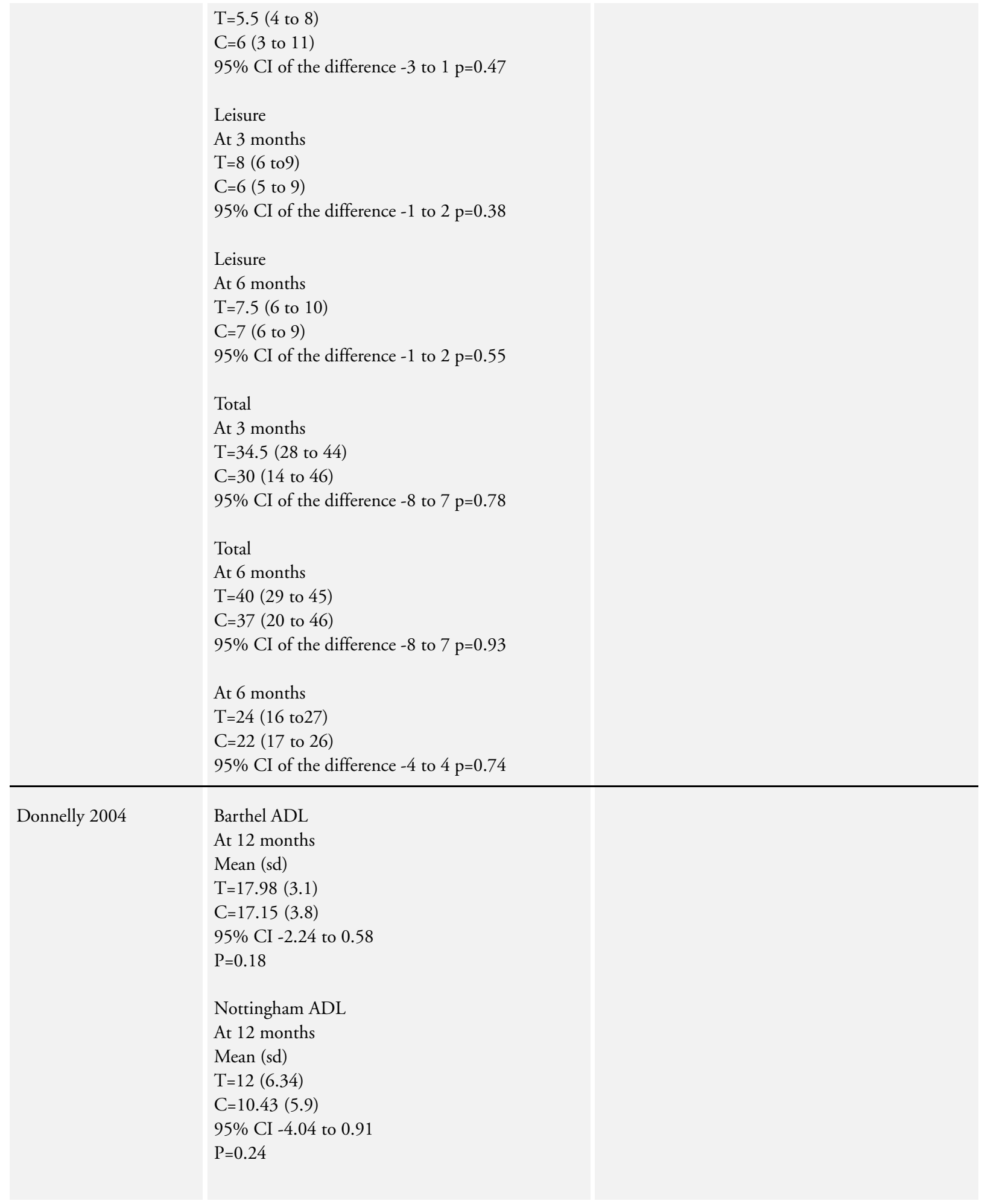


Published data for older patients with a mix of conditions and those recovering from a stroke (Continued)

\begin{tabular}{|c|c|c|}
\hline & $\begin{array}{l}10 \text { m timed walk At } 12 \text { months } \\
\text { Mean (sd) } \\
T=28.13(21.5) \\
C=28.9(28.8) \\
95 \% \text { CI }-16.5 \text { to } 18.14 \\
P=0.34\end{array}$ & \\
\hline Indredavik 2000 & 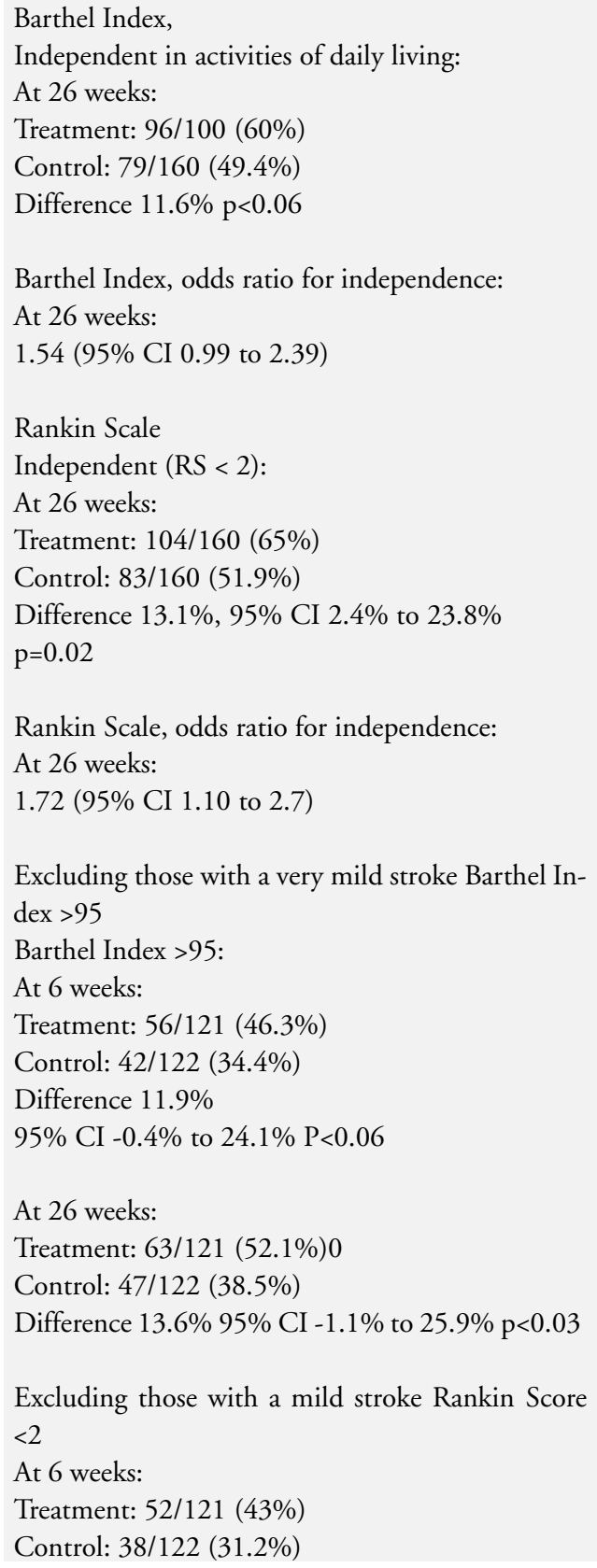 & $\begin{array}{l}\text { Barthel Index } \\
\text { Independent in activities of daily living - authors } \\
\text { reported \%, numbers derived from percentages } \\
\text { Barthel Index, odds ratio for independence - } \\
\text { Barthel Index > } 95 \text { vs. death or Barthel }<95 \\
\text { Rankin Scale, odds ratio for independence - Rankin } \\
\text { scale }<2 \text { vs. Rankin scale } 3 \text { to } 6\end{array}$ \\
\hline
\end{tabular}


Published data for older patients with a mix of conditions and those recovering from a stroke (Continued)

\begin{tabular}{|c|c|c|}
\hline & $\begin{array}{l}\text { Difference } 11.8 \% 95 \% \text { CI }-0.23 \% \text { to } 23.9 \% \mathrm{p}<0 \text {. } \\
056 \\
\text { At } 26 \text { weeks: } \\
\text { Treatment: } 70 / 121(58 \%) \\
\text { Control: } 49 / 122(40.2 \%) \\
\text { Difference } 17.8 \% 95 \% \text { CI } 5.3 \% \text { to } 30.1 \% \mathrm{p}<0.01\end{array}$ & \\
\hline Mayo 2000 & See SF-36 scores in 01.01 .06 & \\
\hline Rodgers 1997 & $\begin{array}{l}\text { Functional status: } \\
\text { At } 3 \text { months: } \\
\text { Oxford Handicap Scale: } \\
\text { 0-2: T 28/45 (62\%) C } 22 / 42(52 \%) \text { difference } 9 . \\
8 \%, 95 \% \text { CI }-10.9 \% \text { to } 30.5 \% \\
\text { 3: T } 8 / 45(18 \%) \text { C } 10 / 42(24 \%) \text { difference } 6 \% \text {, } \\
\text { 95\% CI -23\% to } 11 \% \\
\text { 4-5: T } 9 / 45(20 \%) \text { C } 10 / 42(24 \%) \text { difference } 4 \% \text {, } \\
\text { 95\% CI }-21 \% \text { to } 14 \% \\
\text { Nottingham Extended ADL: median [range] } \\
\text { Mobility: T=3 [0-6]; C=1 [0-6] } \\
\text { Kitchen: } \mathrm{T}=4[0-5] ; \mathrm{C}=3[0-5] \\
\text { Domestic: } \mathrm{T}=1[0-4] ; \mathrm{C}=0[0-5] \\
\text { Leisure: } \mathrm{T}=2[0-4] ; \mathrm{C}=2[0-6] \\
\text { Total: } \mathrm{T}=10[0-18] ; \mathrm{C}=7\{0-21]\end{array}$ & $\begin{array}{l}\text { Oxford Handicap Scale } \\
\text { Nottingham Extended ADL }\end{array}$ \\
\hline Rudd 1997 & $\begin{array}{l}\text { Functional status: } \\
\text { 1. At discharge from hospital: } \\
\text { Treatment mean: } 15 \text { (4) } \\
\text { Control mean: } 15 \text { (4) } \\
\text { At one year: } \\
\text { Treatment mean: } 16 \text { (4) } \\
\text { Control mean: } 16 \text { (4) } \\
\text { 2. At discharge from hospital: } \\
\text { Treatment mean: } 18 \text { (8.4) } \\
\text { Control mean: } 19 \text { (8.3) } \\
\text { At one year: } \\
\text { Treatment mean: } 22(8) \\
\text { Control mean: } 23 \text { (7) } \\
\text { 3. At discharge from hospital: } \\
\text { Treatment mean: } 18 \text { (8.4) } \\
\text { Control mean: } 19 \text { (8.3) } \\
\text { At one year: }\end{array}$ & $\begin{array}{l}\text { 1. At discharge from hospital - Barthel Index (0 - } \\
\text { 20) } \\
\text { Treatment group discharged on average } 12 \text { days post } \\
\text { randomisation and control group at } 18 \text { days. } \\
\text { At one year - Frenchay Aphasia Screening Test } \\
\text { 3. At discharge from hospital - Rivermead activities } \\
\text { of daily living scale } \\
\text { At one year - } 5 \text { metre timed walk }\end{array}$ \\
\hline
\end{tabular}


Published data for older patients with a mix of conditions and those recovering from a stroke (Continued)

\begin{tabular}{|c|c|c|}
\hline & $\begin{array}{l}\text { Treatment mean: } 22(8) \\
\text { Control mean: } 23(7) \\
\text { 4. At discharge from hospital } \\
\text { Treatment mean (secs): } 15(23) \\
\text { Control mean (secs): } 17 \text { (35) } \\
\text { At one year: } \\
\text { Treatment mean (secs): } 12(6) \\
\text { Control mean (secs): } 12(8)\end{array}$ & \\
\hline Suwenwela 2001 & $\begin{array}{l}\text { NIH stroke scale } 0-2 \\
\text { At } 6 \text { months } \\
T=40 / 52(77 \%) \\
C=36 / 50(73 \%) \\
\text { RR } 0.8995 \% \text { CI } 0.44 \text { to } 1.75 \\
P=0.73 \\
\text { Barthel Index } \\
\text { At } 6 \text { months number with a good outcome: } 75-100 \\
T=47 / 52(77 \%) \\
C=43 / 50(88 \%) \\
\text { RR } 0.6995 \% \text { CI } 0.23 \text { to } 2.02 p=0.49\end{array}$ & \\
\hline Widen-Holmqvist 1998 & $\begin{array}{l}\text { Functional status 1: } \\
\text { At } 3 \text { months: } \\
\text { Treatment: } 36 / 41 \\
\text { Control: } 32 / 40 \\
\text { P<0.51 } \\
\text { Functional status 2: } \\
\text { At } 3 \text { months: } \\
\text { Treatment: } 16 / 41(39 \%) \\
\text { Control: } 12 / 40 \text { (30\%) difference } 9 \% 95 \% \text { CI }-11 \text {. } \\
6 \% \text { to } 29.6 \% \\
\text { P<0.53 } \\
\text { Functional status 3: } \\
\text { At } 3 \text { months: } \\
\text { Treatment } 28 / 41(68.3 \%) \\
\text { Control } 25 / 40 \text { (62.5\%) difference } 5.8 \% 95 \% \text { CI - } \\
15 \% \text { to } 26 \% \\
\text { P<0.75 } \\
\text { Functional status } 4: \\
\text { At } 3 \text { months: } \\
\text { Treatment: } 12(8-15) \\
\text { Control: } 12(10-16) \\
\text { P<0.43 }\end{array}$ & $\begin{array}{l}\text { Functional status } 1 \text { - independent in personal ADL } \\
\text { At baseline the treatment group had a } 10 \% \text { lower } \\
\text { coping capacity, and increased frequency of disease } \\
\text { (TIA and diabetes), increased frequency of abnor- } \\
\text { mal CT scans on admission and left hemisphere le- } \\
\text { sions. } \\
\text { Functional status } 2 \text { - independent in instrumental } \\
\text { ADL } \\
\text { Functional status } 3 \text { - independent in Barthel } \\
\text { Functional status } 4 \text { - Median time and IQR (sec) } \\
\text { taken to walk } 10 \mathrm{~m} \\
\text { Motor capacity - Lindmark Motor Capacity Scale, } \\
\text { scale } 0-153 \text {. Median score and } \\
\text { (IQR) } \\
\text { Overall SIP - Sickness Impact Profile } \\
\text { Scale } 0 \text { to } 100 \\
\text { Median and (IQR) } \\
\text { Hi score indicates increased dysfunction. }\end{array}$ \\
\hline
\end{tabular}


Published data for older patients with a mix of conditions and those recovering from a stroke (Continued)

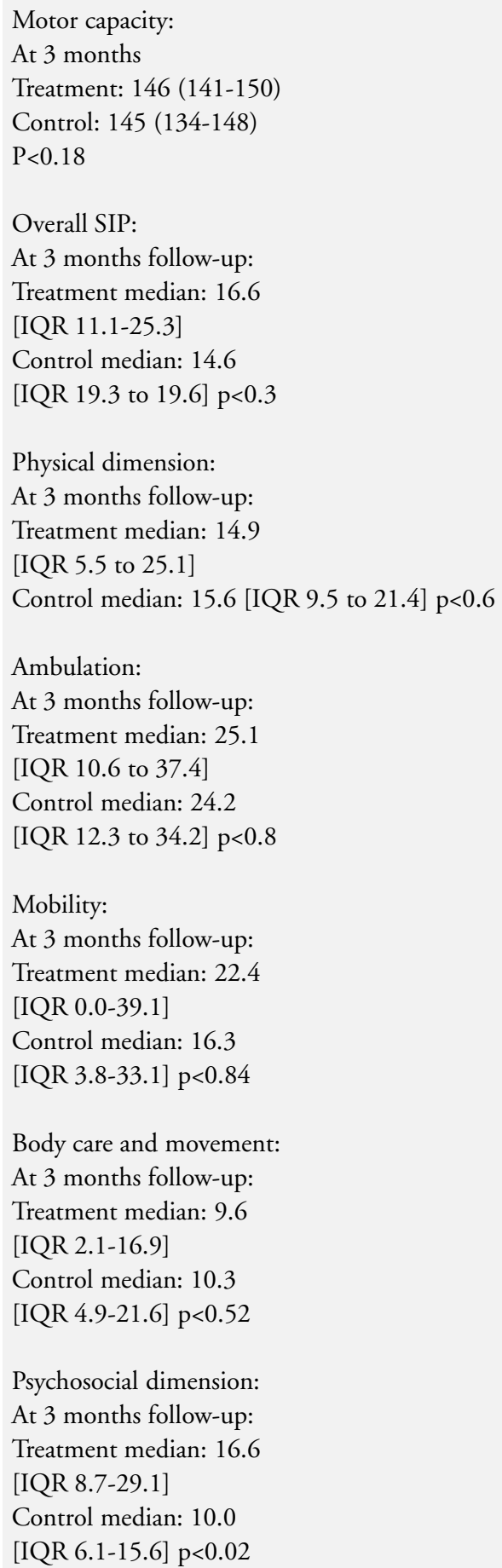


Published data for older patients with a mix of conditions and those recovering from a stroke (Continued)

Social interaction:

At 3 months follow-up:

Treatment median: 15

[IQR 8.4-26.1]

Control median: 10.7

[IQR 3.6-18.8] p<0.06

Alertness behaviour:

At 3 months follow-up:

Treatment median: 9.7

[IQR 0.0-35.5]

Control median: 8.8

[IQR 0.0-19.8] $\mathrm{p}<0.4$

Emotional behaviour:

At 3 months follow-up:

Treatment median: 17.6

[IQR 0.0-31.3]

Control median:0.0

[IQR 0.0-19.7] p $<0.02$

Communication:

At 3 months follow-up:

Treatment median: 18

[IQR 9.2-30.3]

Control median: 9.7

[IQR 0.0-21.5] p $<0.01$

Sleep and rest:

At 3 months follow-up:

Treatment median: 22

[IQR 11.6-33.7]

Control median: 11.7

[IQR 0.0-26.1]

$\mathrm{p}<0.12$

Eating:

At 3 months follow-up:

Treatment median: 5.2

[IQR 0.0-11.3]

Control median: 5.2

[IQR 0.0-11.3]

$\mathrm{p}<0.52$

Work:

At 3 months follow-up:

Treatment median: 0.0

[IQR 0.0-0.0] 
Published data for older patients with a mix of conditions and those recovering from a stroke (Continued)

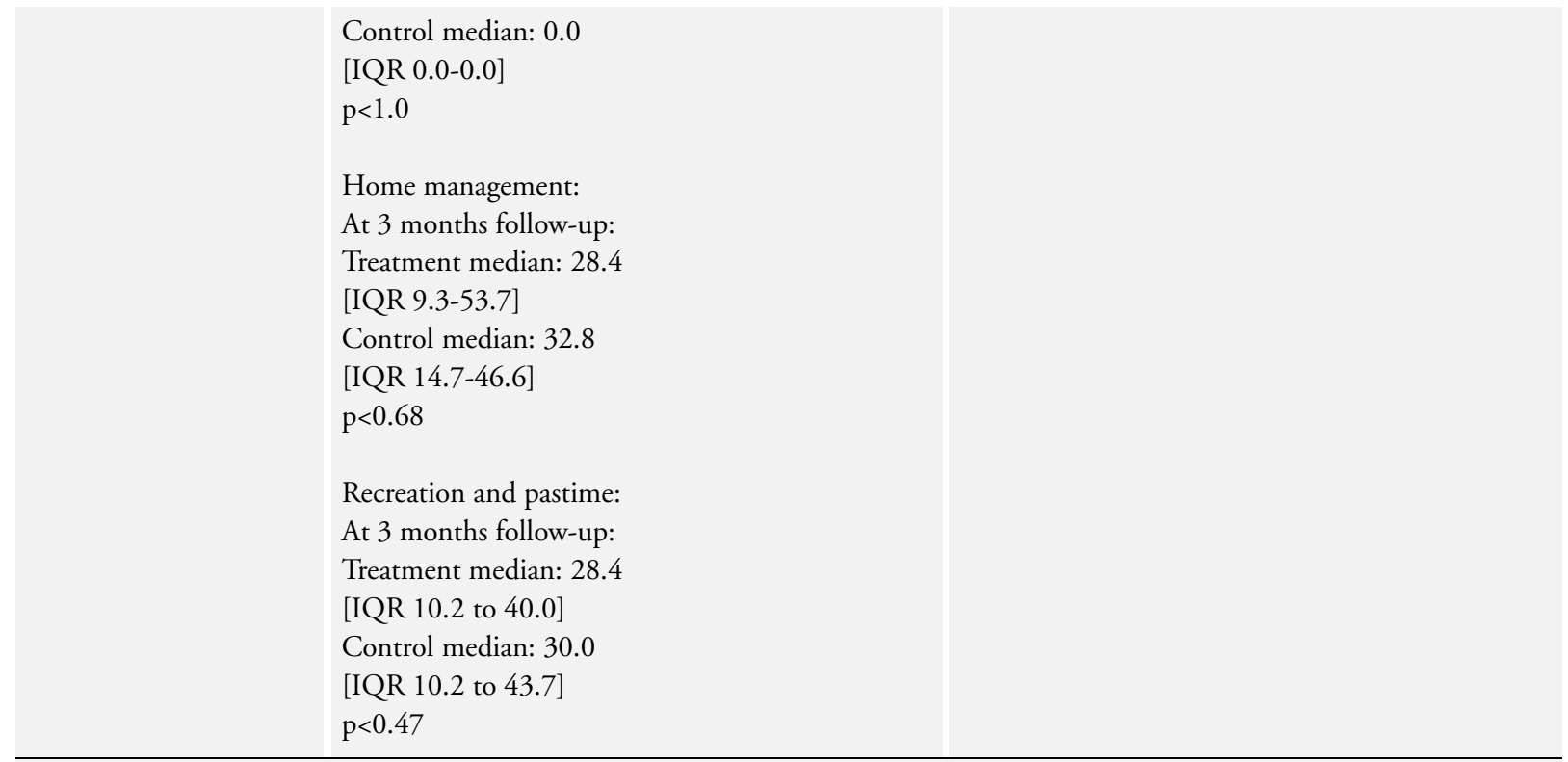

Patient outcomes: quality of life - older people with a mix of conditions

\begin{tabular}{|c|c|}
\hline Cunliffe 2004 & $\begin{array}{l}\text { Euroqol ( }-0.59 \text { to } 1) \\
\text { At } 3 \text { months } \\
\text { Mean difference } 0.07 \text { ( } 95 \% \text { CI }-0.01 \text { to } 0.14) \\
\text { At } 12 \text { months } \\
\text { Mean difference } 0.02 \text { ( } 95 \% \text { CI }-0.06 \text { to } 0.09)\end{array}$ \\
\hline Harris 2005 & $\begin{array}{l}\text { Self reported recovery } \\
\text { At } 10 \text { days } \\
\mathrm{T}=25 / 128(19.5 \%) \\
\mathrm{C}=27 / 129(20.9 \%) \\
\text { At } 30 \text { days } \\
\mathrm{T}=39 / 121(32.2 \%) \\
\mathrm{C}=30 / 124(24.2 \%) \\
\text { At } 90 \text { days } \\
\mathrm{T}=63 / 112(56.3 \%) \\
\mathrm{C}=53 / 116(45.7 \%) \\
\mathrm{SF} 36 \\
\mathrm{Physical} \text { component scale mean }(\mathrm{sd}) \\
\mathrm{T}=34.8(10.7) \text { [n=121] } \\
\mathrm{C}=34.4(9.9) \text { [n=120] } \\
\text { Mental component scale mean }(\mathrm{sd}) \\
\mathrm{T}=53.4(10.5) \text { [n=121] }\end{array}$ \\
\hline
\end{tabular}


Published data for older patients with a mix of conditions and those recovering from a stroke (Continued)

$\mathrm{C}=52.1(12.0)[\mathrm{n}=120]$

\begin{tabular}{|c|c|c|}
\hline Richards 1998 & $\begin{array}{l}\text { Mean differences EQ-5D after adjustment for base- } \\
\text { line differences } \\
\text { At } 4 \text { weeks } \\
\text { Mean difference: } 0.0095 \% \text { CI }-0.09 \text { to } 0.10 \\
\text { At } 3 \text { months: } \\
\text { Mean difference }-0.0495 \% \text { CI }-0.13 \text { to } 0.06\end{array}$ & EQ-5D - possible range 5 to 15 \\
\hline Shepperd 1998 & 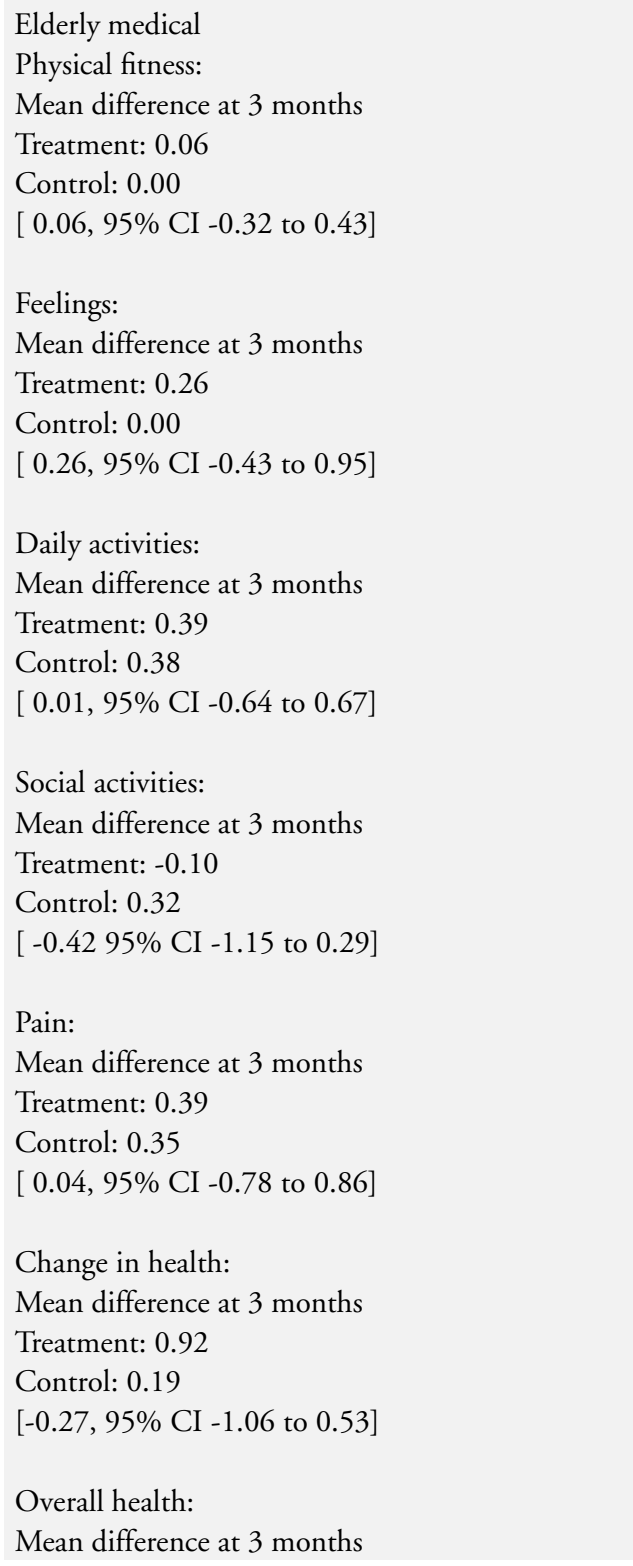 & $\begin{array}{l}\text { Mean change at } 3 \text { months }(\mathrm{sd}) \\
\text { [mean difference, } 95 \% \mathrm{CI}] \\
\text { Physical fitness - Dartmouth COOP charts: } \\
\text { Scale 1-5 (low score = } \\
\text { good quality of life) }\end{array}$ \\
\hline
\end{tabular}


Published data for older patients with a mix of conditions and those recovering from a stroke (Continued)

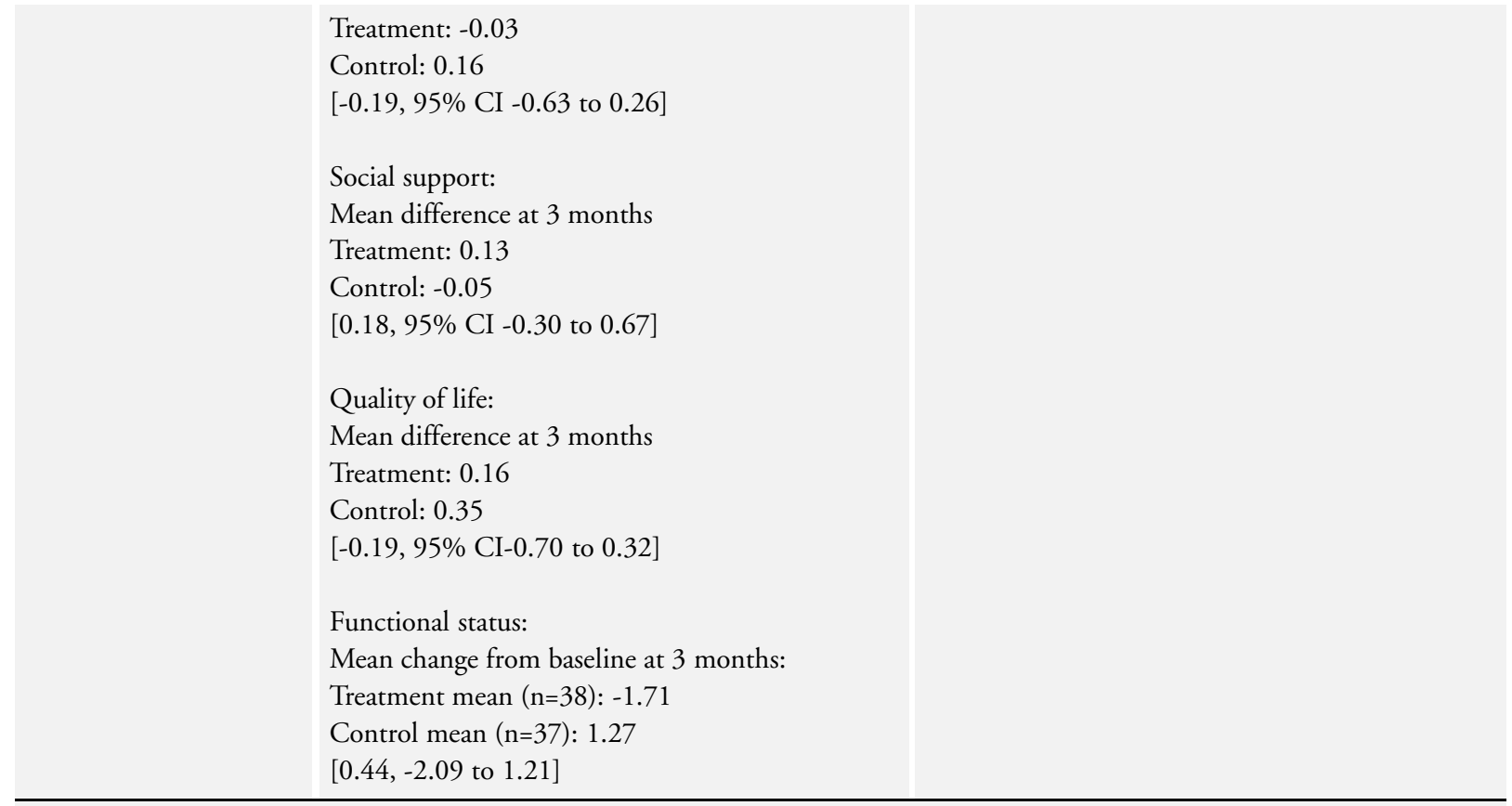

Patient outcomes: quality of life COPD

\begin{tabular}{|c|c|c|}
\hline Shepperd 1998 & $\begin{array}{l}\text { CHRONIC OBSTRUCTIVE AIRWAYS DIS- } \\
\text { EASE: } \\
\text { physical fitness: } \\
\text { Treatment: } 0.40 \\
\text { Control: }-0.45 \\
\text { [0.22, }-0.81 \text { to } 1.25] \\
\text { Feelings: } \\
\text { Treatment: }-0.45 \\
\text { Control: } 0.18 \\
\text { [-0.63, }-2.13 \text { to } 0.86] \\
\text { Daily activities: } \\
\text { Treatment: } 0.00 \\
\text { Control: } 1.09 \\
\text { [-1.09, }-2.27 \text { to } 0.08] \\
\text { Social activities: } \\
\text { Treatment: }-0.82 \\
\text { Control: } 0.18 \\
\text { [-1.00, }-2.48 \text { to } 0.48] \\
\text { Pain: } \\
\text { Treatment: } 0.73 \\
\text { Control: } 0.67\end{array}$ & $\begin{array}{l}\text { Results } \\
\text { Mean change at } 3 \text { months (sd) } \\
\text { [mean difference, } 95 \% \mathrm{CI} \text { ] } \\
\text { Physical fitness - Dartmouth COOP charts: } \\
\text { Scale } 1-5 \text { (low score = } \\
\text { good quality of life) } \\
\text { Feelings - follow- up data for: } \\
\text { treatment } n=10 \\
\text { control } n=11 \\
\text { Dyspnea - CRD questionnaire: } \\
\text { (low score = low } \\
\text { level of functioning) } \\
\text { Treatment } n=10 \\
\text { Control } n=9\end{array}$ \\
\hline
\end{tabular}


Published data for older patients with a mix of conditions and those recovering from a stroke (Continued)

[0.06, -1.24 to 1.36$]$

Change in health:

Treatment: 0.36

Control: 0.73

[-0.37, -2.02 to 1.29 ]

Overall health:

Treatment: -0.18

Control: 0.09

$[-0.27,-1.03$ to 0.48$]$

Social support:

Treatment: 0.00

Control: 0.18

$[-0.18,-1.33$ to 0.97$]$

Quality of life:

Treatment: 0.18

Control: 0.54

$[-0.36,-1.22$ to 0.49$]$

Dyspnea, scale 5-35:

Treatment 0.94

Control -3.85

[4.79, -2.07 to 11.65 ]

Fatigue, scale 4-28:

Treatment -0.40

Control-4.78

[4.38, -0.31 to 9.07]

Emotion, scale 7 - 49:

Treatment -0.80

Control -8.66

[7.86, -2.16 to 17.89 ]

Mastery, scale 4 - 28:

Treatment 0.00

Control -1.44

[1.44, -5.93 to 8.82 ]

Patient outcomes: quality of life/health status - those recovering from a stroke

\begin{tabular}{|c|c|}
\hline Anderson 2000 & $\begin{array}{l}\text { SF-36 at } 6 \text { months follow-up Physical functioning } \\
\text { Mean (sd) } \\
\mathrm{T}=41.3(29.1) \\
\mathrm{C}=42.5(28.1) \\
\mathrm{P}=0.86\end{array}$ \\
\hline
\end{tabular}


Published data for older patients with a mix of conditions and those recovering from a stroke (Continued)

Mean difference $-1.2,95 \%$ CI $-13.8,11.5$

Physical role limitation

Mean (sd)

$\mathrm{T}=70.7(38.7)$

$\mathrm{C}=76.9$ (31.2)

$\mathrm{P}=0.43$

Mean difference $-6.1,95 \%$ CI $-21.7,9.4$

Bodily pain

Mean (sd)

$\mathrm{T}=61.2(33.1)$

$\mathrm{C}=70.1$ (34)

$\mathrm{P}=0.24$

Mean difference -8.8, 95\% CI -23.7, 6.0

General health perceptions

Mean (sd)

$\mathrm{T}=61.8(26.5)$

$\mathrm{C}=67.3$ (21.9)

$\mathrm{P}=0.31$

Mean difference -5.5, 95\% CI -16.3, 5.2

Vitality

Mean (sd)

$\mathrm{T}=53.8(26.2)$

$\mathrm{C}=55.5$ (22.2)

$\mathrm{P}=0.75$

Mean difference $-1.7,95 \%$ CI -12.5, 9.0

Social functioning

Mean (sd)

$\mathrm{T}=74.7$ (31.3)

$\mathrm{C}=82.8$ (23.8)

$\mathrm{P}=0.19$

Mean difference $-8.1,95 \%$ CI -20.4, 4.2

Emotional role limitation

Mean (sd)

$\mathrm{T}=92.7(21.7)$

$\mathrm{C}=93.3$ (24.1)

$\mathrm{P}=0.90$

Mean difference $-0.7,95 \%$ CI $-10.8,9.5$

Mental health

Mean (sd)

$\mathrm{T}=80.5(17.3)$

$\mathrm{C}=82.6$ (13.6) 
Published data for older patients with a mix of conditions and those recovering from a stroke (Continued)

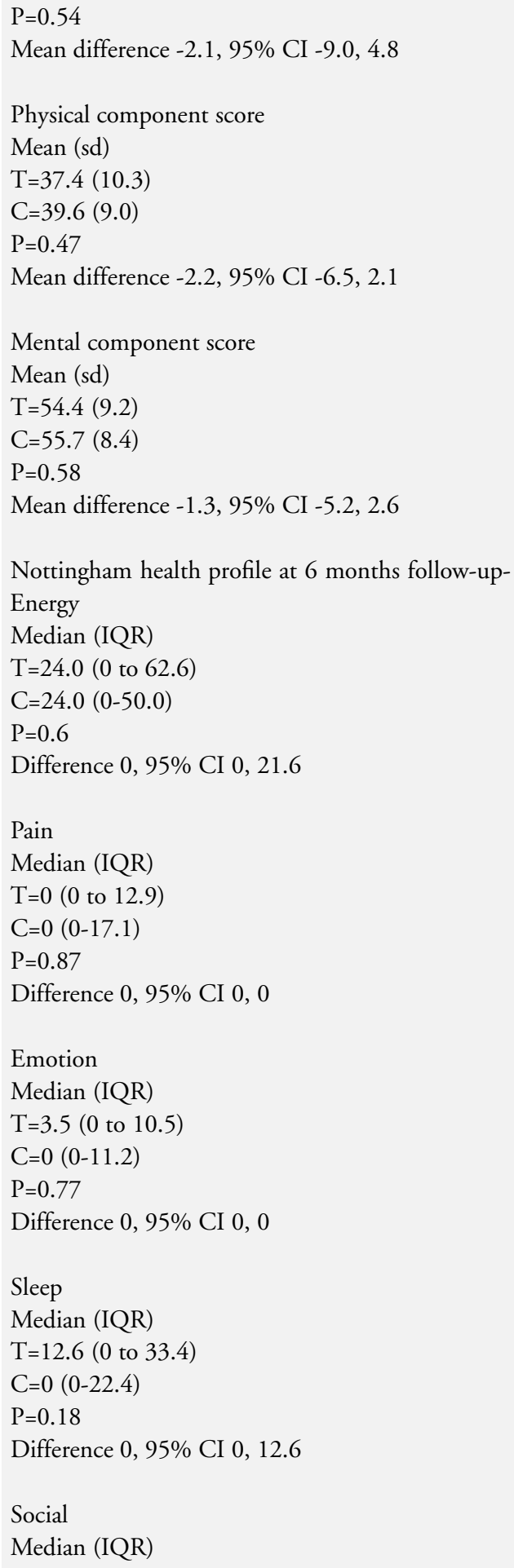


Published data for older patients with a mix of conditions and those recovering from a stroke (Continued)

\begin{tabular}{|c|c|}
\hline & $\begin{array}{l}\mathrm{T}=0(0 \text { to } 22.4) \\
\mathrm{C}=0(0-22) \\
\mathrm{P}=0.41 \\
\text { Difference } 0,95 \% \text { CI } 0,0 \\
\text { Physical } \\
\text { Median (IQR) } \\
\mathrm{T}=23.9(10.9 \text { to } 46.1) \\
\mathrm{C}=21.1 .0(2.6-44.9) \\
\mathrm{P}=0.52 \\
\text { Difference } 0.5,95 \% \mathrm{CI}-9.3,11.8\end{array}$ \\
\hline Askim 2004 & $\begin{array}{l}\text { Nottingham Health Profile for subjective health sta- } \\
\text { tus (energy, pain, emotion, sleep, social isolation, } \\
\text { and physical mobility) Maximum score }=100 \text { within } \\
\text { each domain. High score }=\text { poor health status } \\
\text { Median (IQR) at } 6 \text { weeks follow-up } \\
\text { Energy } \\
\mathrm{T}=24(0.0-60.8) \\
\mathrm{C}=24(0.0-63.2) \\
\mathrm{P}=0.64 \\
\text { Pain } \\
\mathrm{T}=0.0(0.0-9.0) \\
\mathrm{C}=0.0(0.0-12.9) \\
\mathrm{P}=0.44 \\
\text { Emotion } \\
\mathrm{T}=7.0(0.0-17.6) \\
\mathrm{C}=7.1(0.0-19.3) \\
\mathrm{P}=0.58 \\
\text { Sleep } \\
\mathrm{T}=0.0(0.0-35.9) \\
\mathrm{C}=12.6(0.0-35.9) \\
\mathrm{P}=0.69 \\
\text { Social } \\
\mathrm{T}=0.0(0.0-22.0) \\
\mathrm{C}=0.0(0.0-22.5) \\
\mathrm{P}=0.14 \\
\mathrm{Physical} \\
\mathrm{T}=34.7(10.6-57.8) \\
\mathrm{C}=47.1(0.0-78.7) \\
\mathrm{P}=0.67 \\
\mathrm{Median}(\mathrm{IQR}) \text { at } 26 \text { weeks follow-up } \\
\text { Treatment } \mathrm{n}=22 ; \text { Control } \mathrm{n}=28 \\
\text { Energy } \\
\mathrm{T}=24(0.0-24) \\
\mathrm{C}=24(0.0-63.2) \\
\mathrm{P}=0.40\end{array}$ \\
\hline
\end{tabular}


Published data for older patients with a mix of conditions and those recovering from a stroke (Continued)

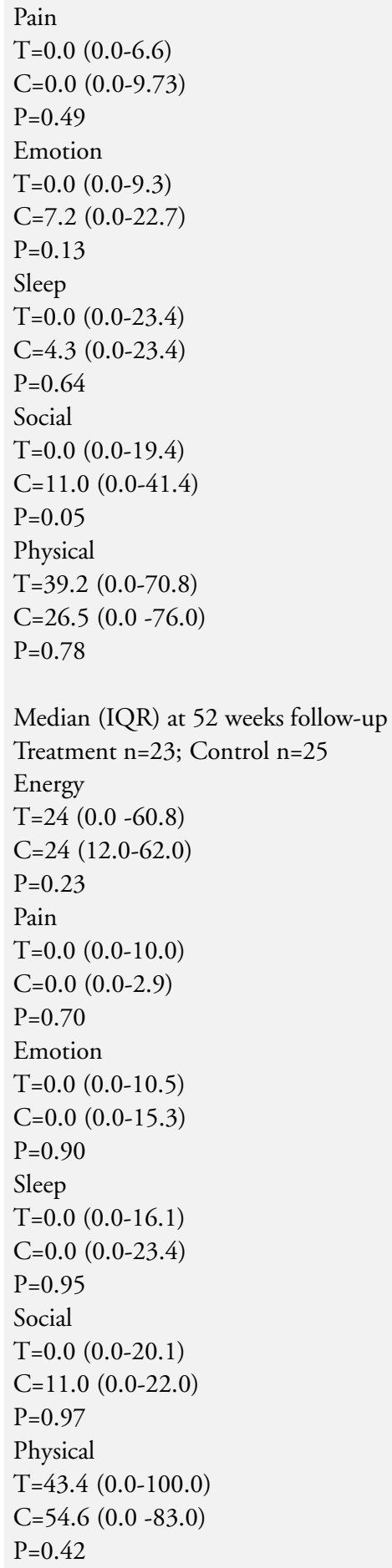


Published data for older patients with a mix of conditions and those recovering from a stroke (Continued)

\begin{tabular}{|c|c|}
\hline & $\begin{array}{l}\text { Global score } \\
\text { At } 6 \text { weeks follow up } \\
\text { Global score median IQR } \\
\mathrm{T}=81.6(71.1-92.1) \\
\mathrm{C}=76.3(59.2-92.1) \\
\mathrm{P}=0.44 \\
\text { Global score mean (sd) } \\
\mathrm{T}=80(15.3) \\
\mathrm{C}=75.9 \text { (18.3) } \\
\text { At } 26 \text { weeks follow-up } \\
\mathrm{Global} \text { score median IQR } \\
\mathrm{T}=81.6(67.8-95.4) \\
\mathrm{C}=76.3(55.9-96.7) \\
\mathrm{P}=0.21 \\
\mathrm{Global} \text { score mean (sd) } \\
\mathrm{T}=82.5(13.7) \\
\mathrm{C}=75.8(19.5) \\
\text { At } 52 \text { weeks follow-up } \\
\mathrm{Global} \text { score median IQR } \\
\mathrm{T}=79(68.4-97.4) \\
\mathrm{C}=81.6(68.4-96.1) \\
\mathrm{P}=0.92 \\
\mathrm{Global} \text { score mean }(\mathrm{sd}) \\
\mathrm{T}=79.8 \text { (16.8) } \\
\mathrm{C}=79.8(17.7)\end{array}$ \\
\hline Donnelly 2004 & $\begin{array}{l}\text { EuroQol } \\
\text { At } 12 \text { months } \\
\text { Mean (sd) } \\
\mathrm{T}=66.36(18.45) \\
\mathrm{C}=68.21(20.31) \\
95 \% \text { CI }-6.2 \text { to } 9.9 \\
\mathrm{P}=0.6 \\
\text { SF } 36 \text { Physical functioning } \\
\text { At } 12 \text { months } \\
\text { Mean (sd) } \\
\mathrm{T}=35.6(31.32) \\
\mathrm{C}=34.7 \text { (32.01) } \\
95 \% \text { CI }-13.7 \text { to } 11.88 \\
\mathrm{P}=0.8 \\
\text { Mental health } \\
\text { At } 12 \text { months } \\
\text { Mean (sd) } \\
\mathrm{T}=69.49 \text { (18.3) } \\
\mathrm{C}=67.3 \text { (20.07) }\end{array}$ \\
\hline
\end{tabular}


Published data for older patients with a mix of conditions and those recovering from a stroke (Continued)

\begin{tabular}{|c|c|}
\hline & $\begin{array}{l}95 \% \text { CI }-9.95 \text { to } 5.58 \\
\mathrm{P}=0.68 \\
\text { Quality of life } \\
\text { Mental health } \\
\text { At } 12 \text { months } \\
\text { Mean (sd) } \\
\mathrm{T}=18.57 \text { (4.3) } \\
\mathrm{C}=18.92(4.74) \\
95 \% \mathrm{CI}-1.5 \text { to } 2.2 \\
\mathrm{P}=0.58\end{array}$ \\
\hline Mayo 2000 & $\begin{array}{l}\text { SF36 subscale: physical function (scored out of } 100) \\
\text { At } 1 \text { month, mean (sd) } \\
\text { T=54.3 (26.7) [n=56] } \\
\text { C=53.4 (26.8) [n=47] } \\
\text { At } 3 \text { months, mean (sd) } \\
\text { T=60.5 (29.5) [n=47] } \\
\text { C=49.2 (31.5) [n=44] } \\
\text { SF36 subscale: role physical function (scored out of } \\
\text { 100) } \\
\text { At } 1 \text { month, mean (sd) } \\
\text { T=23.7 (35.1) [n=56] } \\
\text { C=10.6 (21.3) [n=47] } \\
\text { P }<0.02 \\
\text { Physical function (physical component summary of } \\
\text { the SF36) } \\
\text { At } 3 \text { months, mean (sd) } \\
\text { T=42.9 (10.1) [n=51] } \\
\text { C=37.9 (10.6) [n=44] } \\
\text { P=0.05 } \\
\text { SF36 subscale: emotional (scored out of } 100) \\
\text { At } 1 \text { month, mean (sd) } \\
\text { T=53.6 (45.7) [n=56] } \\
\text { C=53.2 (46.4) [n=47] } \\
\text { At } 3 \text { months, mean (sd) } \\
\text { T=66 (41.9) [n=47] } \\
\text { C=61.4 (40.6) [n=44] } \\
\text { Mental health (mental component summary of } \\
\text { SF36) } \\
\text { At } 3 \text { months, mean (sd) } \\
\text { T=46.5 (11.7) [n=51] } \\
\text { C=46.7 (10.8) [n=44] } \\
\text { NS }\end{array}$ \\
\hline
\end{tabular}


Published data for older patients with a mix of conditions and those recovering from a stroke (Continued)

SF36 subscale: pain index (scored out of 100)

At 1 month, mean (sd)

$\mathrm{T}=73.5(30.7)[\mathrm{n}=56]$

$\mathrm{C}=75.1(26.2)[\mathrm{n}=47]$

At 3 months, mean (sd)

$\mathrm{T}=75.5(26.7)[\mathrm{n}=47]$

$\mathrm{C}=72.1(27.4)[\mathrm{n}=44]$

SF36 subscale: general health perceptions (scored out of 100)

At 1 month, mean (sd)

$\mathrm{T}=62.6(22.9) \quad[\mathrm{n}=56]$

$\mathrm{C}=55.1(24.2)[\mathrm{n}=47]$

At 3 months, mean (sd)

$\mathrm{T}=63.5(20.8)[\mathrm{n}=47]$

$\mathrm{C}=56.7(25.0) \quad[\mathrm{n}=44]$

SF36 subscale: vitality (scored out of 100)

At 1 month, mean (sd)

$\mathrm{T}=53.1(20.8)[\mathrm{n}=56]$

$\mathrm{C}=48.7(25.0)[\mathrm{n}=47]$

At 3 months, mean (sd)

$\mathrm{T}=50.7(23.9)[\mathrm{n}=47]$

$\mathrm{C}=46.4(22.9) \quad[\mathrm{n}=44]$

SF36 subscale: social function (scored out of 100)

At 1 month, mean (sd)

$\mathrm{T}=59.6(33.2)[\mathrm{n}=56]$

$\mathrm{C}=57.2(35.0)[\mathrm{n}=47]$

At 3 months, mean (sd)

$\mathrm{T}=71.3(28.5)[\mathrm{n}=47]$

$\mathrm{C}=64.2(28.7) \quad[\mathrm{n}=44]$

SF36 subscale: mental health index (scored out of 100)

At 1 month, mean (sd)

$\mathrm{T}=67.1(21.9) \quad[\mathrm{n}=56]$

$\mathrm{C}=67.7(22.3)[\mathrm{n}=47]$

At 3 months, mean (sd)

$\mathrm{T}=65.2(20.8)[\mathrm{n}=47]$

$\mathrm{C}=66.4(19.2)[\mathrm{n}=44]$ 
Published data for older patients with a mix of conditions and those recovering from a stroke (Continued)

Control: 5 [3-5

Feelings:

Treatment: 2 [1-5]

Control: 2 [1-5]

Daily activities:

Treatment: 3 [1-5]

Control: $3[1-5]$

Social activities:

Treatment: 3 [1-5]

Control: $4[1-5]$

Pain:

Treatment: 3 [1-5]

Control: 3 [1-5]

Change in health:

Treatment: 2 [1-5]

Control: 2 [1-5]

Overall health:

Treatment: 3 [1-5]

Control: 3 [2-5]

Social support:

Treatment: 1 [1-4]

Control: 1 [1-5]

Quality of life: Treatment: 2 [1-5]

Control: 3 [1-5]

Cognitive ability

\begin{tabular}{|c|c|}
\hline Caplan 2006 & $\begin{array}{l}\text { Mini mental state exam (cognitive function) } \\
\text { At } 1 \text { month, mean (sd) } \\
\mathrm{T}=23.89(6.42) \\
\mathrm{C}=24.52(5.97) \\
\mathrm{P}=0.66 \\
\text { At } 6 \text { months } \\
\mathrm{T}=23.22(6.9) \\
\mathrm{C}=25.18(5.01) \\
\mathrm{P}=0.24 \\
\text { Confusion assessment method (CAM) } \\
\text { Assessed every 2nd day }\end{array}$ \\
\hline
\end{tabular}


Published data for older patients with a mix of conditions and those recovering from a stroke (Continued)

\begin{tabular}{|c|c|}
\hline & 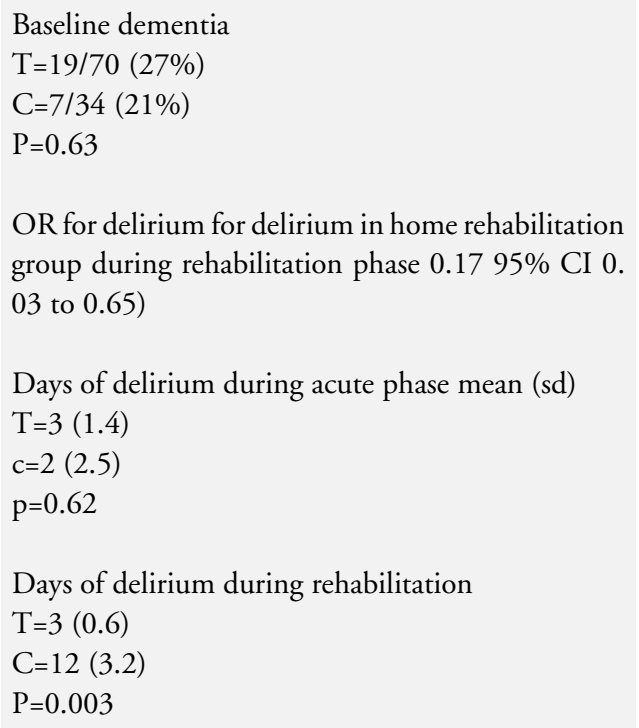 \\
\hline Harris 2005 & $\begin{array}{l}\text { Mini mental state exam (cognitive function) } 10 \text { day } \\
\text { mean change from baseline (sd) } \\
T=0.04(3.01)[n=125] \\
C=-0.01(2.87)[n=129] \\
\text { Difference }-0.0595 \% \text { CI }-0.67,0.77 \\
30 \text { days mean change from baseline (sd) } \\
T=0.36(2.89) \text { [ } n=117] \\
C=0.34(2.77)[n=121] \\
\text { Difference }-0.0295 \% \text { CI }-0.70,0.74 \\
90 \text { day mean change from baseline (sd) } \\
T=0.20(3.55) \text { [n=117] } \\
C=0.72(3.03)[n=109] \\
\text { Difference }-0.4495 \% \text { CI- } 1.38,0.35\end{array}$ \\
\hline
\end{tabular}

Patient outcomes: psychological well-being - older people with a mix of conditions

$\begin{array}{ll}\text { Caplan } 2006 & \begin{array}{l}\text { Geriatric depression scale } \\ \text { At } 1 \text { month } \\ \mathrm{T}=8.84(6.07) \\ \mathrm{C}=8.17(5.73) \\ \mathrm{P}=0.63\end{array} \\ & \text { At } 6 \text { months } \\ \mathrm{T}=7.8(5.6) \\ \mathrm{C}=7.14(3.96) \\ \mathrm{P}=0.62\end{array}$


Published data for older patients with a mix of conditions and those recovering from a stroke (Continued)

\begin{tabular}{|c|c|c|}
\hline Cunliffe 2004 & $\begin{array}{l}\text { GHQ - patient ( } 36 \text { to } 0) \text { At } 3 \text { months } \\
\text { Mean difference }-2.4 \text { ( } 95 \% \text { CI }-4.1 \text { to }-0.7) \\
\text { At } 12 \text { months } \\
\text { Mean difference }-1.9 \text { ( } 95 \% \text { CI }-3.5 \text { to }-0.4)\end{array}$ & \\
\hline Donald 1995 & $\begin{array}{l}\text { Psychological well-being: } \\
\text { At } 6 \text { months: } \\
\text { treatment mean: } 12.4(\mathrm{n}=21) \\
\text { control mean: } 12.1(\mathrm{n}=25)\end{array}$ & $\begin{array}{l}\text { Used the Philadelphia Geriatric Centre Morale } \\
\text { Score (a high score indicating a good outcome). No } \\
\text { p value given, insufficient data to calculate CI }\end{array}$ \\
\hline Harris 2005 & $\begin{array}{l}\text { Functional independence measure - mental } 10 \text { day } \\
\text { mean change from baseline }(\mathrm{sd}) \\
\mathrm{T}=0.67(2.47)[\mathrm{n}=134] \\
\mathrm{C}=1.16(3.34)[\mathrm{n}=134] \\
\text { Difference }-0.4995 \% \text { CI }-1.19,0.22 \\
30 \text { days mean change from baseline (sd) } \\
\mathrm{T}=0.53(2.20) \text { [ }=126] \\
\mathrm{C}=0.74(2.44)[\mathrm{n}=125 \\
\text { Difference }-0.2195 \% \text { CI }-0.79,0.36 \\
90 \text { day mean change from baseline (sd) } \\
\mathrm{T}=0.46(3.19)[\mathrm{n}=124] \\
\mathrm{C}=0.90(4.19)[\mathrm{n}=123] \\
\text { Difference }-0.4195 \% \text { CI- } 1.34,0.52\end{array}$ & \\
\hline Martin 1994 & $\begin{array}{l}\text { Psychological well-being: } \\
\text { At } 6 \text { weeks: } \\
\text { treatment median: } 10 \\
\text { control median: } 12 \\
\text { At } 12 \text { weeks: } \\
\text { treatment median: } 13 \\
\text { control median: } 9.5 \\
\text { Cognitive status: } \\
\text { At } 6 \text { weeks: } \\
\text { treatment median: } 8 \\
\text { control median: } 8 \\
\text { At } 12 \text { weeks: } \\
\text { treatment median: } 9 \\
\text { control median: } 8 \\
\text { Minimental state examination: } \\
\text { At discharge from hospital: } \\
\text { Treatment mean: } 21.7 \text { (7.1) }\end{array}$ & $\begin{array}{l}\text { Psychological well-being - used the Philadelphia } \\
\text { Geriatric Centre Morale Score (scale of } 0 \text { - } 21 \text { ). } \\
\text { No p value given, insufficient data to calculate CI } \\
\text { Cognitive status - abbreviated Mental Test score ( } 0 \\
\text { - 10) (a high score indicating a good outcome). } \\
\text { No p value given, insufficient data to calculate CI }\end{array}$ \\
\hline
\end{tabular}


Published data for older patients with a mix of conditions and those recovering from a stroke (Continued)

Control mean: 21 (7.3)

$[0,-1.2$ to 2.1$]$

\begin{tabular}{|c|c|c|}
\hline Shepperd 1998 & $\begin{array}{l}\text { ELDERLY MEDICAL PATIENTS: } \\
\text { Psychological well-being: } \\
\text { Baseline: } \\
\text { treatment mean: } 6.54(2.28) \\
\text { control mean: } 7.93 \text { (2.67) } \\
\text { Difference at } 3 \text { months: } \\
\text { T: } 0.16 \text { (2.66) } \\
\text { C: } 0.73 \text { (2.24) } \\
\text { Difference -0.88 95\% CI -2.1 to } 0.33 \\
\text { CHRONIC OBSTRUCTIVE AIRWAYS DIS- } \\
\text { EASE: } \\
\text { Psychological well-being: } \\
\text { Baseline: } \\
\text { treatment mean: } 7.61 \text { (2.4) } \\
\text { control mean: } 7.7 \text { (2.68) } \\
\text { Difference at } 3 \text { months: } \\
\text { T: } 0.4 \text { (2.32) } \\
\text { C: } 1.00 \text { (2.93) difference } \\
-0.6,95 \% \text { CI }-3.03 \text { to } 1.83\end{array}$ & $\begin{array}{l}\text { Used the Philadelphia Geriatric Centre Morale } \\
\text { Score (a high score indicating a good outcome) }\end{array}$ \\
\hline
\end{tabular}

Patient outcomes: psychological well-being - those recovering from a stroke

\begin{tabular}{|c|c|}
\hline Bautz-Holter 2002 & $\begin{array}{l}\text { Montgomery Asberg Depression rating scale Me- } \\
\text { dian (IQR) } \\
\text { At } 3 \text { months } \\
\mathrm{T}=1.5 \text { ( } 0 \text { to } 4) \\
\mathrm{C}=2.5 \text { ( } 0 \text { to } 6) \\
95 \% \text { CI of the difference }-2 \text { to } 0 \mathrm{p}=0.10 \\
\text { Median (IQR) } \\
\text { At } 6 \text { months } \\
\mathrm{T}=2(0 \text { to } 6) \\
\mathrm{C}=2(1 \text { to } 5) \\
95 \% \text { CI of the difference }-2 \text { to } 1 \mathrm{p}=0.30 \\
\mathrm{General} \text { health questionnaire Median (IQR) } \\
\text { At } 3 \text { months } \\
\mathrm{T}=19.5 \text { ( } 14 \text { to } 26) \\
\mathrm{C}=26 \text { ( } 19 \text { to } 31 \text { ) } \\
95 \% \text { CI of the difference }-9 \text { to }-1 \mathrm{p}=0.02\end{array}$ \\
\hline
\end{tabular}

Rudd 1997 Hospital anxiety depression scale:

At discharge from hospital:

No (\%) with anxiety:

Normal 
Published data for older patients with a mix of conditions and those recovering from a stroke (Continued)

\begin{tabular}{|c|c|}
\hline & $\begin{array}{l}\text { Treatment: } 89 / 167(70 \%) \\
\text { Control: } 106 / 164(82 \%) \\
\text { P<0.02 X2 test for trend } \\
95 \% \text { CI -22\% to - } 0.81 \% \\
\text { Borderline } \\
\text { Treatment: } 18 / 167(14) \\
\text { Control: } 14 / 164 \text { (11) } \\
\text { Abnormal: } \\
\text { Treatment: } 20 / 167 \text { (16) } \\
\text { Control: } 10 / 164 \text { (8) } \\
\text { Aggregate data for borderline and abnormal groups } \\
\text { (assessed only): } \\
\text { Treatment: } 38 / 126(30.2 \%) \\
\text { Control: } 24 / 130 \text { (18.5\%) } \\
\text { Difference } 11.7 \% \text {, } 95 \% \text { CI } 1.3 \% \text { to } 22 \% \\
\text { Aggregated data for borderline and abnormal (as- } \\
\text { sessed and not assessed): } \\
\text { Treatment: } 38 / 167 \text { (23\%) } \\
\text { Control: } 24 / 164 \text { (14.6\%) } \\
\text { Difference } 8 \%, 95 \% \text { CI }-0.23 \% \text { to } 16.5 \%\end{array}$ \\
\hline
\end{tabular}

Patient satisfaction and preference for place of care - elderly with a medical condition including COPD

\begin{tabular}{|c|c|}
\hline Caplan 2006 & $\begin{array}{l}\text { Patient satisfaction } \\
5 \text { point scale }(1=\text { low, } 5=\text { high }) \\
\text { Mean }(\text { sd) } \\
T=4.66(0.64) \\
\mathrm{C}=4.06(0.94) \\
\mathrm{P}=0.006\end{array}$ \\
\hline Harris 2005 & $\begin{array}{l}\text { Patient satisfactionGood/excellent rating of the ser- } \\
\text { vice } \\
\mathrm{T}=93 / 112(83 \%) \\
\mathrm{C}=87 / 120(72.5 \%) \\
\mathrm{P}<0.05 \\
\text { Did not feel under pressure } \\
\mathrm{T}=111 / 116(95.7 \%) \\
\mathrm{C}=105 / 115(91.3 \%) \\
\mathrm{NS} \\
\text { Yes, would recommend to others } \\
\mathrm{T}=110 / 116(94.8 \%) \\
\mathrm{C}=111 / 115(96.5 \%) \\
\mathrm{NS}\end{array}$ \\
\hline Ojoo 2002 & $\begin{array}{l}\text { Preferred hospital at home: } 26 / 30(87 \%) \\
\text { Control: } 16 / 30(53 \%)\end{array}$ \\
\hline
\end{tabular}


Published data for older patients with a mix of conditions and those recovering from a stroke (Continued)

Difference: $33 \%$, $95 \%$ CI $18 \%$ to $55 \%$

\begin{tabular}{|c|c|c|}
\hline Shepperd 1998 & $\begin{array}{l}\text { ELDERLY MEDICAL PATIENTS: } \\
\text { Patient preference: } \\
\text { At discharge: } \\
\text { Treatment: } 81 \% \\
\text { Control: } 40 \% \\
\text { [ } 41 \%, 20 \% \text { to } 62 \% \text { ] } \\
\text { Patient satisfaction: } \\
\text { At discharge from hospital at home, or hospital: } \\
\text { Treatment }=22.54 \text { (4.74) } \\
\text { Control=22.10 (4.68) } \\
\text { [0.44, }-3.86 \text { to } 4.75 \text { ] } \\
\text { CHRONIC PULMONARY DISEASE: } \\
\text { Patient preference: } \\
\text { At discharge: } \\
\text { Treatment: } 73 \% \\
\text { Control: } 54.5 \% \\
\text { [18.5\%, }-21.3 \% \text { to } 57.7 \% \text { ] } \\
\text { At discharge from hospital at home, or hospital: } \\
\text { Treatment=25.0 (3.11) } \\
\text { Control=24.66 (3.05) } \\
\text { [0.83, -5.23 to } 6.89 \text { ] }\end{array}$ & $\begin{array}{l}\text { [difference, } 95 \% \mathrm{CI} \text { ] } \\
\text { Patient preference - patients reporting they had re- } \\
\text { ceived their preferred place of care } \\
\text { Patient satisfaction - using modified version of sat- } \\
\text { isfaction scale developed by Pound, maximum score } \\
\text { of } 33 \text {, indication high level of satisfaction }\end{array}$ \\
\hline Skwarska 2000 & $\begin{array}{l}\text { Treatment group only: } 95 \% \text { of } 65 \%(79 / 122) \text { of the } \\
\text { patients reported being 'completely satisfied' }\end{array}$ & \\
\hline
\end{tabular}

Patient satisfaction and preference for place of care - recovering from a stroke

Anderson $2000 \quad \begin{aligned} & \text { Patient satisfaction at } 6 \text { months follow-upSatisfied } \\ & \text { with recovery } \\ & \mathrm{T}=33 / 42(81 \%) \\ & \mathrm{C}=29 / 44(73 \%) \\ & \mathrm{P}=0.56 \\ & 95 \% \text { CI }-10.4,26.4 \\ & \text { Satisfied with rehabilitation programme } \\ & \mathrm{T}=37 / 42(90 \%) \\ & \mathrm{C}=32 / 44(80 \%) \\ & \mathrm{P}=0.33 \\ & 95 \% \text { CI }-5.1,25.6 \\ & \text { Satisfied with return home } \\ & \mathrm{T}=36 / 42(95 \%) \\ & \mathrm{C}=36 / 44(90 \%) \\ & \mathrm{P}=0.68\end{aligned}$


Published data for older patients with a mix of conditions and those recovering from a stroke (Continued)

\begin{tabular}{|c|c|c|}
\hline & $\begin{array}{l}95 \% \text { CI }-7.0,16.4) \\
\text { Satisfied with information at time of illness } \\
T=26 / 42(63 \%) \\
\mathrm{C}=21 / 44(53 \%) \\
\mathrm{P}=0.44 \\
95 \% \text { CI }-10.5,32.3 \\
\text { Satisfied with communication with team } \\
\mathrm{T}=33 / 42(81 \%) \\
\mathrm{C}=27 / 44(68 \%) \\
\mathrm{P}=0.28 \\
95 \% \text { CI }-5.9,31.9 \\
\text { Satisfied with understanding of why stroke occurred } \\
\mathrm{T}=16 / 42(39 \%) \\
\mathrm{C}=22 / 44(55 \%) \\
\mathrm{P}=0.22 \\
95 \% \text { CI }-37.4,5.5 \\
\text { Satisfied with current support } \\
\text { T=39/42 (95\%) } \\
\mathrm{C}=36 / 44(90 \%) \\
\mathrm{P}=0.43 \\
95 \% \text { CI }-6.3,16.5\end{array}$ & \\
\hline Donnelly 2004 & $\begin{array}{l}\text { Patient satisfaction At } 12 \text { months } \\
\text { Mean (sd) } \\
\mathrm{T}=10.72(1.44) \\
\mathrm{C}=9.7(2.1) \\
95 \% \mathrm{CI}-1.7 \text { to }-0.24 \\
\mathrm{P}=0.02 \\
\text { Overall satisfactionAt } 12 \text { months } \\
\text { Mean (sd) } \\
\mathrm{T}=50(9.7) \\
\mathrm{C}=42.6(11.2) \\
95 \% \mathrm{CI}-11.7 \text { to }-3.1 \\
\mathrm{P}=0.001\end{array}$ & \\
\hline Rudd 1997 & $\begin{array}{l}\text { Patient satisfaction with hospital care: } \\
\text { Treatment: } 78 / 136(79 \%) \\
\text { Control: } 59 / 126(65 \%) \\
\text { [14\%, } 1 \% \text { to } 27 \%] \\
\text { Patient satisfaction with therapy: } \\
\text { Treatment: } 56 / 136(58 \%) \\
\text { Control: } 46 / 126(51 \%) \\
\text { [7\%, }-6 \% \text { to } 22 \%]\end{array}$ & [difference, 95\% CI] \\
\hline
\end{tabular}


Published data for older patients with a mix of conditions and those recovering from a stroke (Continued)

Patient satisfaction with community care:

Treatment: $28 / 136(42 \%)$

Control: 29/126 (51\%)

[11\%, $-26 \%$ to $9 \%]$

\begin{tabular}{|c|c|c|}
\hline Suwenwela 2001 & $\begin{array}{l}\text { Satisfaction with treatment } \\
\text { At day } 10 \text { the number wanting to be treated at home } \\
T=41 / 52(79 \%) \\
C=15 / 50(30 \%)\end{array}$ & \\
\hline Widen-Holmqvist 1998 & $\begin{array}{l}\text { Patient satisfaction with active participation in treat- } \\
\text { ment: } \\
\text { In favour of treatment group } \\
P<0.02 \\
\text { Patient satisfaction in general: } \\
\text { Treatment: } 68 / 136(83 \%) \\
\text { Control: } 52 / 126(83 \%) \\
{[-12 \% \text { to } 13 \%]}\end{array}$ & $\begin{array}{l}\text { [difference, } 95 \% \mathrm{CI} \text { ] } \\
\text { Patient satisfaction with active participation in treat- } \\
\text { ment - no data reported. Results on other dimen- } \\
\text { sions of patient satisfaction not reported }\end{array}$ \\
\hline
\end{tabular}

\section{Carer outcomes}

\begin{tabular}{|c|c|}
\hline Askim 2004 & $\begin{array}{l}\text { Carer strain index } \\
\text { At } 6 \text { weeks follow-up } \\
\text { Mean } \\
T=24.5(2.3) \quad(n=29) \\
C=23.5(2.4) \quad(n=29) \\
\text { At } 26 \text { weeks follow up } \\
\text { Mean } \\
T=24.2(2.5) \quad(n=22) \\
C=25.0(1.6) \quad(n=23) \\
\text { At } 52 \text { weeks follow up } \\
\text { Mean } \\
T=24.3(2.7) \quad(n=23) \\
C=24.8(1.9) \quad(n=22)\end{array}$ \\
\hline Caplan 2006 & $\begin{array}{l}\text { Carer satisfaction } \\
5 \text { point scale }(1=\text { low, } 5=\text { high }) \text { Mean }(\mathrm{sd}) \\
\mathrm{T}=4.47(0.86) \\
\mathrm{C}=4.08(1.04) \\
\mathrm{P}=0.19\end{array}$ \\
\hline Cunliffe 2004 & $\begin{array}{l}\text { GHQ - carer ( } 36 \text { to } 0) \\
\text { At } 3 \text { months } \\
\text { Mean difference }-2.0(95 \% \text { CI }-3.8 \text { to }-0.1) \\
\text { At } 12 \text { months }\end{array}$ \\
\hline
\end{tabular}


Published data for older patients with a mix of conditions and those recovering from a stroke (Continued)

Mean difference -1.1 (95\% CI -3.7 to 1.5$)$

\begin{tabular}{|c|c|c|}
\hline Donnelly 2004 & $\begin{array}{l}\text { Carer strain } \\
\text { At } 12 \text { months } \\
\text { Mean (sd) } \\
T=5.9(2.9)[n=27] \\
C=6.0(4.2)[n=25] \\
95 \% \text { CI }-2.14 \text { to } 2.3 \\
P=0.93\end{array}$ & \\
\hline Harris 2005 & $\begin{array}{l}\text { Relative satisfaction } \\
\text { Good/excellent rating of service } \\
\mathrm{T}=46 / 69(67 \%) \\
\mathrm{C}=24 / 58(41.4 \%) \\
\mathrm{P}<0.004 \\
\text { Did not feel under pressure } \\
\mathrm{T}=57 / 69(82.6 \%) \\
\mathrm{C}=34 / 55(61.8 \%) \\
\mathrm{P}<0.009 \\
\text { Yes, would recommend to others } \\
\mathrm{T}=62 / 63(98.4 \%) \\
\mathrm{C}=51 / 57(89.5 \%) \\
\mathrm{P}=0.03 \\
\mathrm{C} \text { arer strain } \\
(0=\text { low, } 13=\text { high }) \text { Mean } \\
\mathrm{T}=4.6(3.6) \\
\mathrm{C}=6.2(3.7) \\
\mathrm{P}<0.02\end{array}$ & \\
\hline Ojoo 2002 & $\begin{array}{l}\text { Carer preferred hospital at home: } \\
\text { treatment: } 17 / 20(85 \%) \\
\text { control: } 6 / 14(43 \%) \\
\text { difference } 42 \% 95 \% \text { CI } 12 \% \text { to } 72 \%\end{array}$ & \\
\hline Rodgers 1997 & $\begin{array}{l}\text { General health questionnaire (30): } \\
\text { Median [range] } \\
\text { Treatment: } 5[0-21](\mathrm{n}=22) \\
\text { Control: } 5[1-27](\mathrm{n}=19)\end{array}$ & \\
\hline Rudd 1997 & $\begin{array}{l}\text { Care Giver Strain: } \\
\text { Treatment: } 5(4) \\
\text { Control: } 4(3) \\
\text { Treatment median } 5 \text { (range } 0-12) \\
\text { Control median } 3 \text { (range } 0-12) \\
\text { Carer satisfaction with hospital care: } \\
\text { Treatment: } 60(74 \%) \\
\text { Control: } 41(67 \%)\end{array}$ & $\begin{array}{l}\text { Care Giver Strain - mean (sd) } \\
\text { Scale } 0 \text { to } 13 \\
\text { Carer satisfaction with hospital care - denominator } \\
\text { is not clear }\end{array}$ \\
\hline
\end{tabular}


Published data for older patients with a mix of conditions and those recovering from a stroke (Continued)

\begin{tabular}{|c|c|c|}
\hline & $\begin{array}{l}\text { [7\%, }-8 \% \text { to } 22 \%] \\
\text { Carer satisfaction with therapy: } \\
\text { Treatment: } 40(53 \%) \\
\text { Control: } 28(46 \%) \\
\text { [7\%, }-9 \% \text { to } 24 \%] \\
\text { Carer satisfaction with community support: } \\
\text { Treatment: } 28(42 \%) \\
\text { Control: } 29(51 \%) \\
\text { [9\%, }-26 \% \text { to } 9 \%] \\
\text { Carer satisfaction in general: } \\
\text { Treatment: } 68(83 \%) \\
\text { Control:52 }(83 \%) \\
\text { [difference } 0 \%,-12 \% \text { to } 13 \%]\end{array}$ & \\
\hline Shepperd 1998 & $\begin{array}{l}\text { ELDERLY MEDICAL PATIENTS: } \\
\text { Carer Strain Index: } \\
\text { Treatment }=0.96 \\
\text { Control=-0.22 } \\
\text { [1.17, } 95 \% \text { CI }-0.47 \text { to } 2.82] \\
\text { Carers reporting they had received their preferred } \\
\text { place of care: } \\
\text { At } 3 \text { months: } \\
\text { Treatment: } 78 \% \\
\text { control: } 70 \% \\
\text { Difference: } 8 \% \text {, } \\
\text { (-16.6\% to } 33.8 \%) \\
\text { CHRONIC OBSTRUCTIVE AIRWAYS DIS- } \\
\text { EASE: } \\
\text { Carer Strain Index: } \\
\text { Treatment=-0.33 } \\
\text { Control=2.75 } \\
\text { [-3.08, } 95 \% \text { CI -8.19 to } 2.02] \\
\text { Carers reporting they had received their preferred } \\
\text { place of care At } 3 \text { months: } \\
\text { Treatment: } 87.5 \% \\
\text { Control: } 71.4 \% \\
\text { Difference: } 16.1 \% \\
\text { (-24.5\% to } 56.6 \%)\end{array}$ & Carer Strain Index - mean change from baseline \\
\hline \multicolumn{3}{|l|}{ GP views } \\
\hline Caplan 2006 & $\begin{array}{l}\text { General Practitioner satisfaction } \\
5 \text { point scale }(1=\text { low, } 5=\text { high)Mean (sd) } \\
\mathrm{T}=4.06(0.96)\end{array}$ & \\
\hline
\end{tabular}


Published data for older patients with a mix of conditions and those recovering from a stroke (Continued)

\begin{tabular}{ll} 
& $\mathrm{C}=3.78(0.97)$ \\
& $\mathrm{P}=0.41$ \\
\hline Skwarska 2000 & $\begin{array}{l}\text { For hospital at home group: } \\
\text { 50\% response rate: no increase in demand of service: } \\
65 \% ; 33 \% \text { no decrease in demand for service; } 2 \% \\
\text { reported increased demand for service }\end{array}$ \\
\hline
\end{tabular}

Readmission to hospital - short and long-term (not included in the meta- analysis)

\begin{tabular}{|c|c|}
\hline Anderson 2000 & $\begin{array}{l}\text { At } 6 \text { months } \\
\mathrm{T}=15 / 42(36 \%) \\
\mathrm{C}=11 / 44(25 \%) \\
\text { difference } 11 \%\end{array}$ \\
\hline Bautz-Holter 2002 & $\begin{array}{l}\text { At } 3 \text { months } \\
\mathrm{T}=2 / 34 \\
\mathrm{C}=4 / 32 \\
\text { At } 6 \text { months } \\
\mathrm{T}=3 / 34 \\
\mathrm{C}=4 / 31\end{array}$ \\
\hline Caplan 2006 & $\begin{array}{l}\text { With } 28 \text { days after end of rehabilitation } \\
\mathrm{T}=13 / 70(21 \%) \\
\mathrm{C}=8 / 34(24.2 \%) \\
\mathrm{P}=1.0\end{array}$ \\
\hline Donald 1995 & $\begin{array}{l}\text { Readmission at } 6 \text { months: } \\
\mathrm{T}=9 / 30 \\
\mathrm{C}=6 / 30\end{array}$ \\
\hline Donnelly 2004 & $\begin{array}{l}\text { At } 12 \text { months } \\
\mathrm{t}=6 / 59(10.2 \%) \\
\mathrm{c}=7 / 54(13 \%)\end{array}$ \\
\hline Martin 1994 & $\begin{array}{l}\text { At } 6 \text { weeks: } \\
\text { treatment: } 4 / 29(13.8 \%) \text { control: } 9 / 25(36 \%) \text {, ob- } \\
\text { served difference: }-22.2 \% \\
95 \% \text { CI - } 45 \% \text { to } 0.4 \% \\
\text { At } 12 \text { weeks: } \\
\text { treatment: } 5 / 29(17.2 \%) \\
\text { control: } 5 / 25(20 \%) \\
\text { observed difference }-2.8 \% \\
95 \% \text { CI }-23.6 \% \text { to } 18.1 \% \\
\text { At one year alive and never re admitted: } \\
\text { treatment }=12 / 29(41.4 \%) \text { control }=4 / 25(16 \%) \\
\text { observed difference } 25.4 \%\end{array}$ \\
\hline
\end{tabular}


Published data for older patients with a mix of conditions and those recovering from a stroke (Continued)

\begin{tabular}{l|l} 
& $\mathrm{p}<0.05$ \\
& $95 \%$ CI $2.4 \%$ to $48 \%$ \\
& \\
& $\begin{array}{l}\text { or readmitted } \\
\text { treatment: } 17 / 29(58.6 \%) \\
\text { control: } 21 / 25(84 \%) \\
\text { difference }-25.4 \%, 95 \% \text { CI }-48.4 \% \text { to }-2.4 \%\end{array}$ \\
\hline Rudd 1997 & At 1 year \\
& $\begin{array}{l}\text { T=44/167 }(26.4 \%) \\
\text { C=42/164 }(25.6 \%) \\
\text { difference } 0.74 \%\end{array}$ \\
\hline Widen-Holmqvist 1998 & At 6 months \\
& T=8/41 (19.5\%) \\
& C=11/40 $(27.5 \%)$ \\
\hline
\end{tabular}

Length of stay: in-patient days (including readmission days) - recovering from a stroke

\begin{tabular}{|c|c|}
\hline Anderson 2000 & $\begin{array}{l}\text { Total hospital bed days Median (IQR) } \\
\mathrm{T}=15(8.0,22.0) \\
\mathrm{C}=30(17.3,48.5) \\
\text { Median difference }-15,95 \% \text { CI }-22.0 \text { to }-6.0 \\
\text { Readmission stay (days) Median (IQR) } \\
\mathrm{T}=6.0 \text { (3.0 to } 39.0) \\
\mathrm{C}=4.0(1.0 \text { to } 29.0) \\
\text { Median difference } 2.0,95 \% \text { CI }-7.0 \text { to } 18.0 \\
\mathrm{P}=0.26\end{array}$ \\
\hline Askim 2004 & $\begin{array}{l}\text { Inpatient length of stay } \\
\text { Stroke Unit mean }(\mathrm{sd}) \\
\mathrm{T}=12.9(10.3) \\
\mathrm{C}=13.6(15.0) \\
\text { Stroke unit }+ \text { rehabilitation clinics mean }(\mathrm{sd}) \\
\mathrm{T}=23.5(30.5) \\
\mathrm{C}=30.5(44.8)\end{array}$ \\
\hline Bautz-Holter 2002 & $\begin{array}{l}\text { Length of stay } \\
\text { Median } \\
T=22 \text { days } \\
\mathrm{C}=31 \text { days } \\
\mathrm{P}=0.09\end{array}$ \\
\hline Donnelly 2004 & $\begin{array}{l}\text { Length of stay } \\
\mathrm{T}=42 \text { days, median } 31 \\
\mathrm{C}=50 \text { days, median } 32\end{array}$ \\
\hline
\end{tabular}


Published data for older patients with a mix of conditions and those recovering from a stroke (Continued)

\begin{tabular}{|c|c|}
\hline Indredavik 2000 & $\begin{array}{l}\text { Average stroke unit length of stay: } \\
\text { Treatment: } 11 \text { days } \\
\text { Control: } 11 \text { days } \\
\text { Average hospital length of stay (stroke unit plus re- } \\
\text { habilitation): } \\
\text { Treatment: } 18.6 \text { days } \\
\text { Control: } 31.1 \text { days }\end{array}$ \\
\hline Mayo 2000 & $\begin{array}{l}\text { Length of hospital stay } \\
\text { Mean days } \\
\mathrm{T}=9.8(5.3) \\
\mathrm{C}=12.4(7.4) \\
\text { Length of stay to include hospital length of stay + } \\
\text { rehabilitation hospital Mean days } \\
\mathrm{T}=9.8(5.3) \\
\mathrm{C}=16.1(14.6)\end{array}$ \\
\hline Rodgers 1997 & $\begin{array}{l}\text { Hospital length of stay: } \\
\text { Median: } \\
\text { Treatment : } 13 \text { days (IQR 8-25) } \\
\text { Control: } 22 \text { days (IQR 10-57) } \\
\mathrm{P}<0.02\end{array}$ \\
\hline Rudd 1997 & $\begin{array}{l}\text { Hospital length of stay: } \\
\text { Length of stay to randomisation } \\
\text { treatment mean: } 22(25) \\
\text { control mean: } 25 \text { ( } 30) \\
\text { Length of stay from randomisation to discharge: } \\
\text { Treatment mean ( } \mathrm{n}=167): 12(19) \\
\text { Control mean ( } \mathrm{n}=164): 18(24) \\
\text { Mean difference }-6 \text { days, } 95 \% \text { CI }-10.7 \text { to }-1.32 \\
\text { Treatment median: } 6 \text { (range } 0 \text { to } 149) \\
\text { Control median: } 12 \text { (range } 0 \text { to } 236) \\
\text { P < } 0.0001 \text { ( } 95 \% \text { CI for median }-6 \text { to }-2 \text { ) } \\
\text { No data for hospital at home length of stay } \\
\text { CI for median difference reported by authors }\end{array}$ \\
\hline Widen-Holmqvist 1998 & $\begin{array}{l}\text { Hospital length of stay: } \\
\text { Treatment mean } 14 \text { days (range } 5 \text { to } 33 \text { ) } \\
\text { Control mean } 29 \text { days (range } 5 \text { to } 136 \text { ) } \\
52 \% \text { reduction, } p<0.0008\end{array}$ \\
\hline
\end{tabular}

\section{Hospital length of stay - elderly medical}


Published data for older patients with a mix of conditions and those recovering from a stroke (Continued)

\begin{tabular}{|c|c|}
\hline Caplan 2006 & $\begin{array}{l}\text { Acute inpatient length of stay } \\
\text { Acute ward } \\
\mathrm{T}=18.73(11.39) \\
\mathrm{C}=17.03(8.68) \\
\mathrm{P}=0.45 \\
\text { Hospital los } \\
\mathrm{T}=20.31(12.45) \\
\mathrm{C}=40.09(23.22) \\
\mathrm{P}=0.0001 \\
\text { Rehabilitation los } \\
\mathrm{T}=15.97(9.37) \\
\mathrm{C}=23.09(19.41) \\
\mathrm{P}=0.02 \\
\text { Total los from admission to end of rehabilitation } \mathrm{T}= \\
34.91(15.37) \\
\mathrm{C}=40.09(23.22) \\
\mathrm{P}=0.19\end{array}$ \\
\hline Cotton 2002 & $\begin{array}{l}\text { Mean days for initial stay } \\
\mathrm{T}=3.2 \text { ( } 1 \text { to } 16) \\
\mathrm{C}=6.1 \text { ( } 1 \text { to } 13) \\
\text { Additional days due to readmission }(\mathrm{n}=12) \\
\mathrm{T}=8.75 \\
\mathrm{C}=7.83 \\
\text { difference } 0.9295 \% \text { CI }-6.5 \text { to } 8.3\end{array}$ \\
\hline Cunliffe 2004 & $\begin{array}{l}\text { Median IQR (mean) length of stay from random- } \\
\text { ization to discharge } \\
\text { T=6 IQR } 4 \text { to } 13 \text { (12) } \\
\mathrm{C}=13 \text { IQR } 6 \text { to } 24 \text { (21) } \\
\text { Median difference } 4 \text { (95\% CI } 3 \text { to } 7 \text { ) } \\
\text { Median IQR (mean) length of stay from random- } \\
\text { ization to } 3 \text { months } \\
\mathrm{T}=9 \text { IQR } 4 \text { to } 22 \text { (17) } \\
\mathrm{C}=18 \text { IQR } 7 \text { to } 34 \text { (23) } \\
\text { Median difference } 5 \text { (95\% CI } 2 \text { to } 8 \text { ) } \\
\text { Median IQR (mean) length of stay from random- } \\
\text { ization to } 12 \text { months } \\
\text { T=15 IQR } 6 \text { to } 45 \text { (29) } \\
\text { C=21 IQR } 9 \text { to } 50 \text { (39) } \\
\text { Median difference } 4 \text { (95\% CI } 1 \text { to 9) }\end{array}$ \\
\hline
\end{tabular}


Published data for older patients with a mix of conditions and those recovering from a stroke (Continued)

\begin{tabular}{|c|c|c|}
\hline Donald 1995 & $\begin{array}{l}\text { Hospital length of stay: } \\
\text { Days between randomisation and discharge home } \\
\text { (median days): } \\
\text { treatment: } 5 \text { days } \\
\text { control: } 11 \text { days } \\
\text { p = } 0.002 \\
\text { Total days of care (hospital plus hospital at home): } \\
\text { No data }\end{array}$ & \\
\hline Martin 1994 & $\begin{array}{l}\text { Hospital length of stay: } \\
\text { At } 12 \text { weeks: } \\
\text { treatment mean: } 22.4 \text { days } \\
\text { control mean: } 44.8 \text { days } \\
\text { Total days of care (hospital plus hospital at home): } \\
\text { No data }\end{array}$ & No $p$ value given, insufficient data to calculate CI \\
\hline Ojoo 2002 & $\begin{array}{l}\text { Mean days } \\
\mathrm{T}=5.9 \\
\mathrm{C}=7.4 \\
\text { difference }-1.5\end{array}$ & \\
\hline Richards 1998 & $\begin{array}{l}\text { Hospital length of stay: } \\
\text { Hospital length of stay for patients with a medical } \\
\text { condition: } \\
\text { Treatment }(\mathrm{n}=50) \text { mean:39.12 }(23.59) \\
\text { Control }(\mathrm{n}=25) \text { mean:50.12 }(23.11) \\
\text { Difference }-11,95 \% \text { CI }-22.4 \text { to }-0.44\end{array}$ & $\begin{array}{l}\text { Mean (sd) unless stated otherwise } \\
\text { Data obtained from authors }\end{array}$ \\
\hline Shepperd 1998 & $\begin{array}{l}\text { Hospital length of stay: } \\
\text { Elderly medical } \\
\text { Treatment }(\mathrm{n}=50): 12.84(14.69) \\
\text { Control }(\mathrm{n}=44): 13.20(14.19) \\
\text { difference }-0.36 \\
95 \% \text { CI }-6.30 \text { to } 5.57 \\
\text { Chronic obstructive airways disease } \\
\text { treatment: } 6.93(3.39) \\
\text { control: } 12.12(7.49) \\
\text { difference }-5.18 \\
95 \% \text { CI }-9.48 \text { to }-0.89\end{array}$ & \\
\hline Skwarska 2000 & $\begin{array}{l}\text { Median total length of stay } \\
\text { treatment: } 7 \\
\text { control: } 5 \\
\text { median difference } 2 \text { days } \mathrm{p}<0.01 \\
\text { Hospital at home visits: }\end{array}$ & \\
\hline
\end{tabular}


Published data for older patients with a mix of conditions and those recovering from a stroke (Continued)

Mean 3.8 per patient

\begin{tabular}{|c|c|c|}
\hline \multicolumn{3}{|l|}{ Cost } \\
\hline Anderson 2000 & 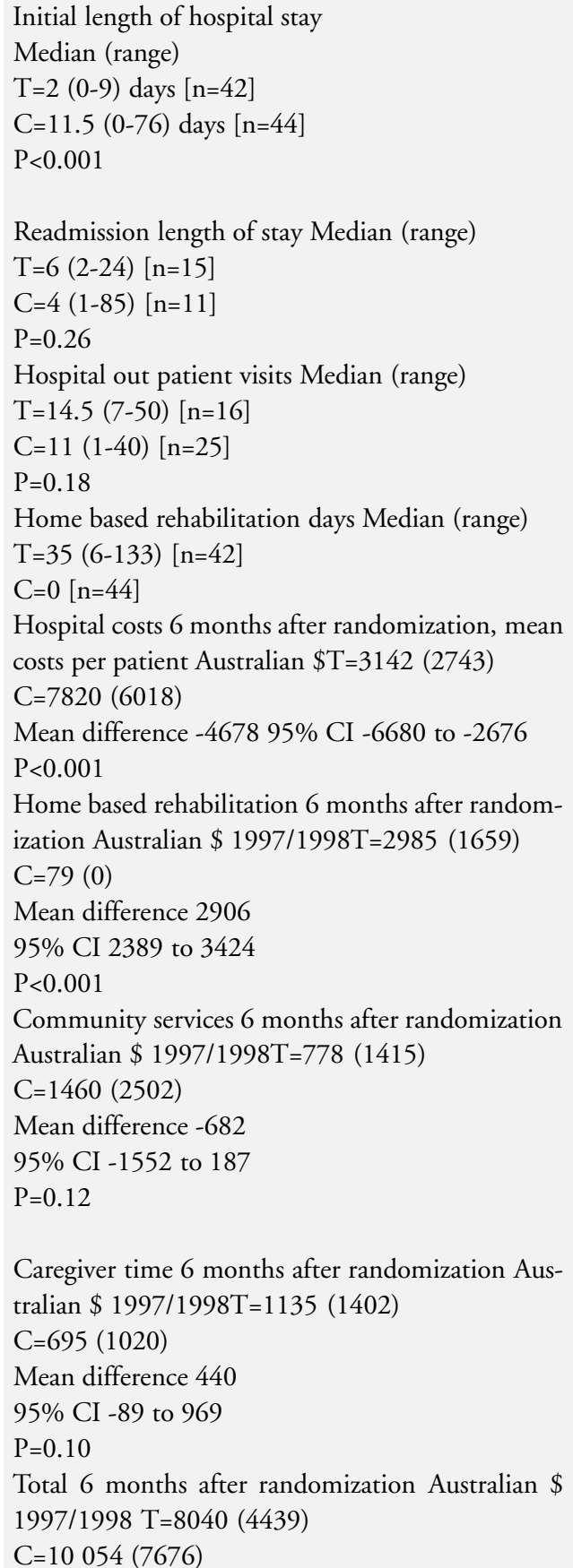 & $\begin{array}{l}\text { Costs calculated for each patient's use of health care } \\
\text { resources in the } 6 \text { months from randomisation, with } \\
\text { an average per patient cost used if detailed informa- } \\
\text { tion on patients was not available }\end{array}$ \\
\hline
\end{tabular}


Published data for older patients with a mix of conditions and those recovering from a stroke (Continued)

\begin{tabular}{|c|c|c|}
\hline & $\begin{array}{l}\text { Mean difference }-2013 \\
95 \% \text { CI }-4696 \text { to } 669 \\
P=0.14 \\
\text { Sensitivity analysis: impact on health care costs } \\
\$ \text { Aust } \\
\text { Initial hospital costs } 75 \% \text { of baseline } \\
T=7255 \text { ( }-785) \\
C=8099 \text { (-1955) } \\
\text { Initial hospital costs } 50 \% \text { of baseline } \\
T=6469 \text { ( }-1571) \\
C=6144(-3910) \\
\text { Home based rehabilitation at } 25 \% \text { increased cost } \\
T=8787 \text { ( } 747) \\
C=10074 \text { (20) } \\
\text { Home based rehabilitation at } 50 \% \text { increased cost } \\
T=9533 \text { (1493) } \\
C=10093 \text { (39) } \\
\text { Home based rehabilitation at } 75 \% \text { of baseline } \\
T=7294(-746) \\
C=10034(-20) \\
\text { Patients with mild disability (Barthel Index score } \\
91-100) \\
T=5565 \text { ( }-2475) \\
C=8165 \text { ( }-1889)\end{array}$ & \\
\hline Caplan 2006 & $\begin{array}{l}\text { Overall Cost } \\
\text { Acute + rehabilitation phase : overall cost } \\
\mathrm{T}=\mathrm{A} \$ 18,147(\$ 9816) \\
\mathrm{C}=\mathrm{A} \$ 25,042(£ 15,041) \\
\mathrm{P}=0.01 \\
\text { In UK£ } \\
\mathrm{T}=7680(4154) \\
\mathrm{C}=10598(6365) \\
\text { Rehabilitation phase overall cost } \\
\mathrm{T}=\mathrm{A} \$ 5,961(\$ 3210) \\
\mathrm{C}=\mathrm{A} \$ 14,413(\$ 12631) \\
\mathrm{P}<0.0001 \\
\text { In UK£ } \\
\mathrm{T}=2523(1347) \\
\mathrm{C}=6100(5345)\end{array}$ & $\begin{array}{l}\text { Details of methods used to calculate costs not avail- } \\
\text { able. }\end{array}$ \\
\hline
\end{tabular}


Published data for older patients with a mix of conditions and those recovering from a stroke (Continued)

\begin{tabular}{|c|c|c|}
\hline Cunliffe 2004 & $\begin{array}{l}\text { Total mean cost per case at } 12 \text { months } \\
\mathrm{T}=£ 8,361(£ 540)+/-£ 1,059 \\
\mathrm{C}=£ 10,088(£ 713)+/-£ 1,398 \\
\text { Difference } £-1,727 \mathrm{p}=0.05495 \% \mathrm{CI}+/-£ 2,481\end{array}$ & $\begin{array}{l}\text { Health care service perspective, resource use quan- } \\
\text { tified using data collected from service providers } \\
\text { for } 12 \text { months after randomisation and on recorded } \\
\text { client contact time for hospital at home. Cost of the } \\
\text { initial hospital admission and readmissions was est- } \\
\text { miated based on length of stay and cost per bed day } \\
\text { by clinical specialty using NHS costs } 2000 / 2001 \text {. } \\
\text { Referrals to social services included in the costs }\end{array}$ \\
\hline
\end{tabular}

\begin{tabular}{|c|c|c|}
\hline Donnelly 2004 & $\begin{array}{l}\text { Cost } \\
\text { At } 6 \text { months } \\
\text { Mean cost per patient (sd) } \\
\text { Hospital in patients } \\
T=£ 7831 \text { (5000) } \\
\mathrm{C}=£ 9864 \text { ( } £ 8198) \\
95 \% \mathrm{CI} \text { - } 2407 \text { to } £ 6472.5 \\
\mathrm{P}=0.74 \\
\text { All community services } \\
\mathrm{T}=£ 3468 \text { ( } £ 4612) \\
\mathrm{C}=£ 3655 \text { ( } £ 4531) \\
95 \% \mathrm{CI} £ 2917.8 \text { to } £ 3292.6 \\
\mathrm{P}=0.96 \\
\mathrm{Combined} \text { package } \\
\mathrm{T}=£ 11759 \text { ( } £ 8600) \\
\mathrm{C}=£ 13337 \text { ( } £ 11182) \\
95 \% \mathrm{CI} £ 5035.6 \text { to } £ 8189.1 \\
\mathrm{P}=0.92\end{array}$ & $\begin{array}{l}\text { Health service perspective, financial accounts were } \\
\text { used to cost hospital care; costs collected from pa- } \\
\text { tients using a service use questionnaire and unit costs } \\
\text { of health and social care to cost hospital at home } \\
\text { care. }\end{array}$ \\
\hline Mayo 2000 & $\begin{array}{l}\text { Costs of resources used at } 3 \text { months: mean cost per } \\
\text { patient Can } \$ \text { (sd) Post randomization acute care } \\
\text { bed days } \\
\mathrm{T}=1383.28 \text { (1599.97) } \\
\mathrm{C}=2220.25 \text { (2321.9) } \\
\text { Rehabilitation bed days } \\
\mathrm{T}=136.7 \text { (1041.1) } \\
\mathrm{C}=1061.89(3484.24) \\
\text { Readmission bed days } \\
\mathrm{T}=364.03 \text { (1794.84) } \\
\mathrm{C}=1793.01 \text { (5504.66) } \\
\text { Home intervention } \\
\mathrm{T}=942.87 \text { (505.45) } \\
\mathrm{C}=0 \\
\text { CLSC visits }\end{array}$ & $\begin{array}{l}\text { Health care perspective at the patient level. Unit } \\
\text { costs included overhead costs and an allowance for } \\
\text { the opportunity cost of buildings and land. Cost for } \\
3 \text { months follow-up included }\end{array}$ \\
\hline
\end{tabular}


Published data for older patients with a mix of conditions and those recovering from a stroke (Continued)

\begin{tabular}{|c|c|c|}
\hline & $\begin{array}{l}\mathrm{T}=124.83(259.85) \\
\mathrm{C}=144.76(280.09) \\
\text { Outpatient visits } \\
\mathrm{T}=381.31(760.17) \\
\mathrm{C}=730.7(947.93) \\
\text { ER visits } \\
\mathrm{T}=62.07(117.93) \\
\mathrm{C}=61.72(162.14) \\
\text { Physician billings } \\
\mathrm{T}=539.67(545.74) \\
\mathrm{C}=764.96(724.83) \\
\text { Total costs } \\
\mathrm{T}=77,84.25(3858.36) \\
\mathrm{C}=11,065.2(7504.19) \\
\text { difference } \$-3,280.95 \mathrm{p}<0.0001\end{array}$ & \\
\hline Rudd 1997 & $\begin{array}{l}\text { Average annual cost: } \\
\text { Treatment: } £ 811,984 \text { ( } £ 4,862 \text { per patient } \\
\text { Control: } £ 1,040,276 \text { ( } £ 6,343 \text { per patient) } \\
\text { Cost of non inpatient care: } \\
\text { Treatment: } £ 323,625 \text { ( } £ 1,938 \text { per patient) } \\
\text { Control: } £ 178,526 \text { ( } £ 1,089 \text { per patient) } \\
\text { Total health care costs: } \\
\text { Treatment: } £ 1,135,609 \text { ( } £ 6,800 \text { per patient) } \\
\text { Control: } £ 1,218,802(£ 7,432 \text { per patient) difference } \\
£-632.00\end{array}$ & $\begin{array}{l}\text { Cost data financial year } 1997 \text {. Costs calculated at } \\
\text { the level of the patient by using data from provider } \\
\text { departments and other published sources }\end{array}$ \\
\hline Shepperd 1998 & $\begin{array}{l}\text { Costs at } 3 \text { months follow-up: Elderly medical pa- } \\
\text { tients: } \\
\text { Hospital costs per patient: } \\
\text { Median Treatment: } £ 913.76 \text { (IQR } £ 243.31 \text { to } \\
£ 2045.68 \text { ) } \\
\text { Mean: } £ 1376.38 \text { (1370) } \\
\text { Median Control: } £ 1,366.16 \text { (IQR } £ 629.1 \text { to } £ 2033 \text {. } \\
\text { 5) } \\
\text { Mean: } £ 1654.2 \text { (1501.4) } \\
\text { p>0.21 } \\
\text { Mean hospital at home costs: } \\
\text { Treatment: } £ 793.4 \text { (811.4) } \\
\text { Total health service costs: } \\
\text { Treatment group: } \\
\text { Median } £ 1,705.3 \text { (IQR } 913.83 \text { to } 3,121.55 \text { ) } \\
\text { Mean: } £ 2279.74 \text { (1765.4) } \\
\text { Control group: }\end{array}$ & $\begin{array}{l}\text { Mann Whitney U test } \\
\text { Cost data financial year 1994/1995. Health ser- } \\
\text { vice perspective, dependency scores developed to ac- } \\
\text { count for the different resouces used during a pa- } \\
\text { tient's inpatient admission. Costs calculated at the } \\
\text { patient level }\end{array}$ \\
\hline
\end{tabular}


Published data for older patients with a mix of conditions and those recovering from a stroke (Continued)

\begin{tabular}{|c|c|c|}
\hline & $\begin{array}{l}\text { Median } £ 1,388.8 \text { (IQR } 645.1 \text { to } 2,094.9 \text { ) } \mathrm{p}>0.09 \\
\text { Mean } £ 1712.6 \text { (1518) } \\
\text { CHRONIC OBSTRUCTIVE AIRWAYS DIS- } \\
\text { EASE: } \\
\text { Hospital costs: } \\
\text { Median Treatment: } £ 1,389.53 \text { (IQR } £ 821.65 \text { to } £ 1 \text {, } \\
\text { 993.97) } \\
\text { Median Control: } £ 1,198 \text { (IQR } £ 712 \text { to } £ 1,508.2 \text { ) } \\
\text { p>0.56 } \\
\text { Mean hospital at home costs: } \\
\text { Treatment: } £ 710.6 \text { ( } 526.5 \text { ) } \\
\text { Total health service costs: } \\
\text { Median Treatment: } £ 2,379.7 \text { (IQR } 1,458.1 \text { to } 2 \text {, } \\
759.1 \text { ) } \\
\text { Median Control: } £ 1,247.6 \text { (IQR } 772.5 \text { to } 1,619.2 \text { ) } \\
\text { median difference } £ 1132.10 \mathrm{p}<0.01\end{array}$ & \\
\hline Skwarska 2000 & $\begin{array}{l}\text { Mean cost to the health service: treatment: } £ 877 \text {. } \\
00 \text {, control: } £ 1,753\end{array}$ & $\begin{array}{l}\text { Cost data financial year } 97 / 98 \\
\text { Costs based on average cost per bed day in the respi- } \\
\text { ratory unit. GP costs calculated from unit costs esti- } \\
\text { mated by Personal \& Social Services Research Unit, } \\
\text { Kent }\end{array}$ \\
\hline
\end{tabular}

Use of other services - elderly with a medical condition

\begin{tabular}{|c|c|}
\hline Cunliffe 2004 & $\begin{array}{l}\text { Attending geriatric day hospital: } \\
\text { Over } 12 \text { months } \\
T=21 / 185(11 \%) \\
C=57 / 185(31 \%) \\
\text { RR } 0.47(95 \% \text { CI } 0.23 \text { to } 0.56) \\
\text { Mean hospital outpatient visits over } 12 \text { months } \\
T=3.4 \\
C=3.3 \\
P=0.85 \\
\text { Mean GP visits over } 12 \text { months } \mathrm{T}=6 \\
C=6.7 \\
P=0.16\end{array}$ \\
\hline Martin 1994 & $\begin{array}{l}\text { At } 6 \text { weeks: } \\
\text { Home care: } \\
\text { treatment: } 2 / 24(8.3 \%) \text { control }=8 / 10(80 \%) \\
\text { p< } 0.05 \\
\text { observed difference: } 71.7 \% \\
95 \% \text { CI - } 99 \% \text { to }-44 \% \\
\text { At } 12 \text { weeks: }\end{array}$ \\
\hline
\end{tabular}


Published data for older patients with a mix of conditions and those recovering from a stroke (Continued)

\begin{tabular}{l|l} 
District nurse visits: treatment: $11 / 21(52.4 \%)$ con- \\
trol: $3 / 11(27.3 \%)$ \\
p< 0.05 \\
observed difference: $25.1 \%$ \\
$95 \%$ CI $-9 \%$ to $59 \%$ \\
Receipt of social services \\
Over 12 months \\
T=145/185 (78\%) \\
C=151/185 (82\%) \\
RR $0.96(95 \%$ CI 0.87 to 1.06$)$ \\
\hline
\end{tabular}

Use of other services - recovering from a stroke

\begin{tabular}{ll}
\hline Anderson 2000 & Use of community services \\
& $\mathrm{T}=28 / 42(67 \%)$ \\
& $\mathrm{C}=30 / 44(68 \%)$ \\
& Difference $1 \%, 95 \%$ CI $-21 \%$ to $18 \%$ \\
\hline
\end{tabular}

Bautz-Holter 2002

$$
\begin{aligned}
& \text { Provision of district nursing } \\
& \text { At } 3 \text { months } \\
& \text { T=13 }(36.1)[\mathrm{n}=34] \\
& \text { C=7 }(22)[\mathrm{n}=32] \\
& \text { At } 6 \text { months } \\
& \text { T=9 }(26.5)[\mathrm{n}=34] \\
& \text { C=6 (19.4) }[\mathrm{n}=31] \\
& \text { Provision of home care } \\
& \text { At } 3 \text { months } \\
& \text { T=16 (44.4) }[\mathrm{n}=34] \\
& \text { C=13 (40.6) }[\mathrm{n}=32] \\
& \text { At } 6 \text { months } \\
& \text { T=17 (50) }[\mathrm{n}=34] \\
& \text { C=14 (45.2) }[\mathrm{n}=31] \\
& \text { Provision of occupational therapy } \\
& \text { At } 3 \text { months } \\
& \text { T=7 (19) }[\mathrm{n}=34] \\
& \text { C=5 (15.6) }[\mathrm{n}=32] \\
& \text { At } 6 \text { months } \\
& \text { T=2 (5.9) }[\mathrm{n}=34] \\
& \text { C=4 (12.9) }[\mathrm{n}=31] \\
& \text { Provision of physiotherapy } \\
& \text { At } 3 \text { months } \\
& \text { T=22 (61.1) }[\mathrm{n}=34] \\
& \text { C=14 (43.8) }[\mathrm{n}=32] \\
& \text { At } 6 \text { months }
\end{aligned}
$$


Published data for older patients with a mix of conditions and those recovering from a stroke (Continued)

$$
\begin{aligned}
& \mathrm{T}=17(50)[\mathrm{n}=34] \\
& \mathrm{C}=11(35.5)[\mathrm{n}=31]
\end{aligned}
$$

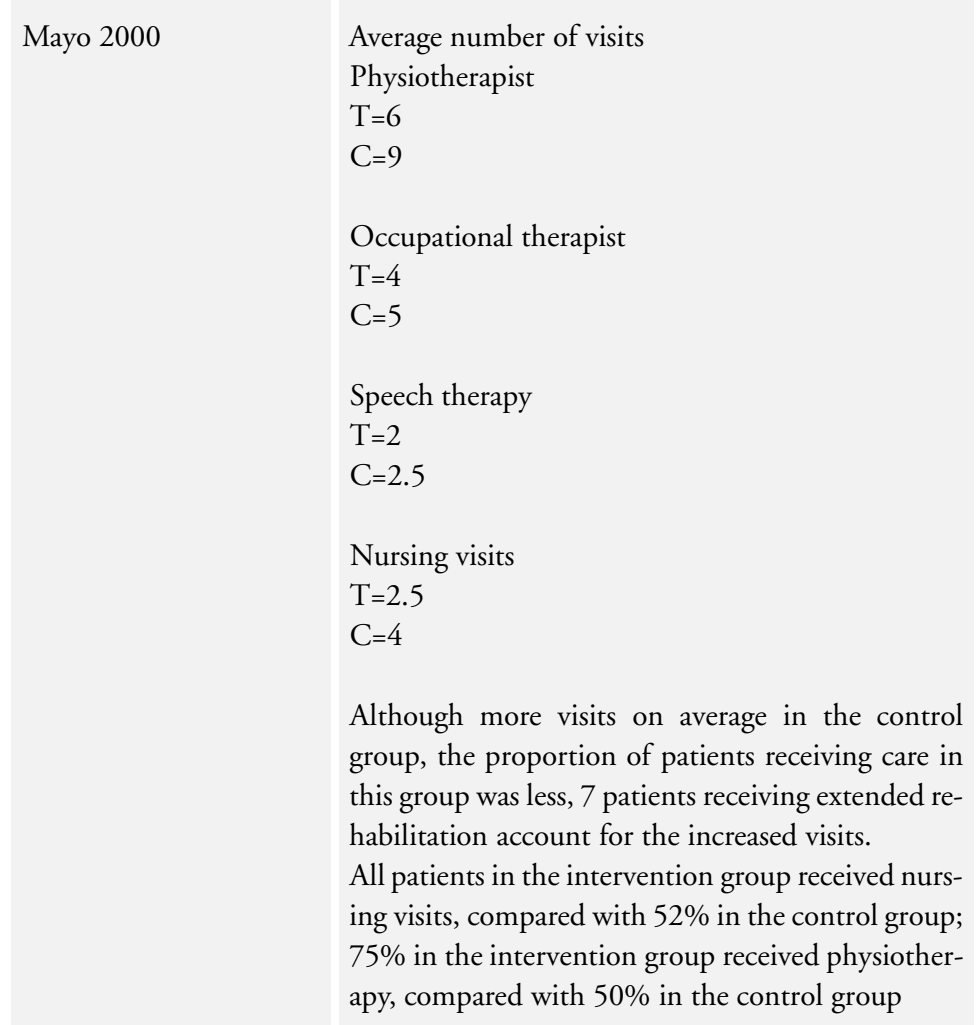

Patients' place of residence at follow up

\begin{tabular}{l|l|l}
\hline Anderson 2000 & At 6 months \\
& Admitted to residential care \\
& T=2/42 (5\%) \\
& C $=5 / 44(11 \%)$ \\
& Difference $-6 \%, 95 \%$ CI $-18 \%$ to $4.8 \%$ \\
\hline Bautz-Holter 2002 & Institional care \\
& At 3 months \\
& T=2/40 \\
& C $=5 / 37$ \\
& OR3.0 $(0.5$ to 24.0$)$ \\
& At 6 months \\
T $=1 / 40$ \\
C $=5 / 36$ \\
OR $6.395 \%$ CI 0.6 to 305
\end{tabular}


Published data for older patients with a mix of conditions and those recovering from a stroke (Continued)

\begin{tabular}{|c|c|}
\hline Donald 1995 & $\begin{array}{l}\text { At } 6 \text { months: } \\
\text { Nursing home: } \\
\text { treatment: } 2 / 30(6.6 \%) \\
\text { control: } 5 / 30(16.7 \%) \\
\text { observed difference: }-10.1 \% \\
95 \% \text { CI }-26 \% \text { to } 6.05 \%\end{array}$ \\
\hline Indredavik 2000 & $\begin{array}{l}\text { Discharge residence: } \\
\text { Discharged to another institution at } 6 \text { weeks: } \\
\text { Treatment: } 37 / 160(23.1 \%) \\
\text { Control: } 64 / 160(40 \%) \\
\text { Difference p < } 0.001 \\
\text { Discharge residence: } \\
\text { At home at } 6 \text { weeks: } \\
\text { Treatment: } 119 / 160(74.4 \%) \\
\text { Control: } 89 / 160(55.6 \%) \\
\text { p < } 0.01 \\
\text { At home at } 26 \text { weeks: Treatment: } 126 / 160(79 \%) \\
\text { Control: } 117 / 160(73 \%) \\
\text { p < } 0.24 \\
\text { Discharged to another institution at } 26 \text { weeks: } \\
\text { Treatment: } 21 / 160(13.1 \%) \\
\text { Control: } 28 / 160(17.5 \%) \\
\text { P < } 0.001\end{array}$ \\
\hline Martin 1994 & $\begin{array}{l}\text { Home at } 6 \text { weeks: } \\
\text { treatment: } 24 / 29(82.7 \%) \\
\text { control: } 10 / 25 \text { ( } 40 \%) \text { observed difference: } 42.7 \% \\
\text { p < } 0.001 \\
95 \% \text { CI } 20 \% \text { to } 66 \% \\
\text { Home at } 12 \text { weeks: treatment: } 21 / 29(72 \%) \text { control: } \\
11 / 25 \text { ( } 44 \%) \text { observed difference } 28 \% \\
\text { p }<0.05 \\
95 \% \text { CI } 3 \% \text { to } 54 \% \\
\text { Home at one year: } \\
\text { treatment: } 17 / 29(58.6 \%) \text { control: } 10 / 25(40 \%) \text { ob- } \\
\text { served difference } 18.6 \% \\
95 \% \text { CI }-8 \% \text { to } 45 \% \\
\text { Residential care: At } 6 \text { weeks: } \\
\text { treatment: } 0 / 29 \text { ( } 0 \%) \\
\text { control: } 3 / 25 \text { (12\%) } \\
\text { observed difference }-12 \% \\
95 \% \text { CI }-24.7 \% \text { to } 0.74 \%\end{array}$ \\
\hline
\end{tabular}


Published data for older patients with a mix of conditions and those recovering from a stroke (Continued)

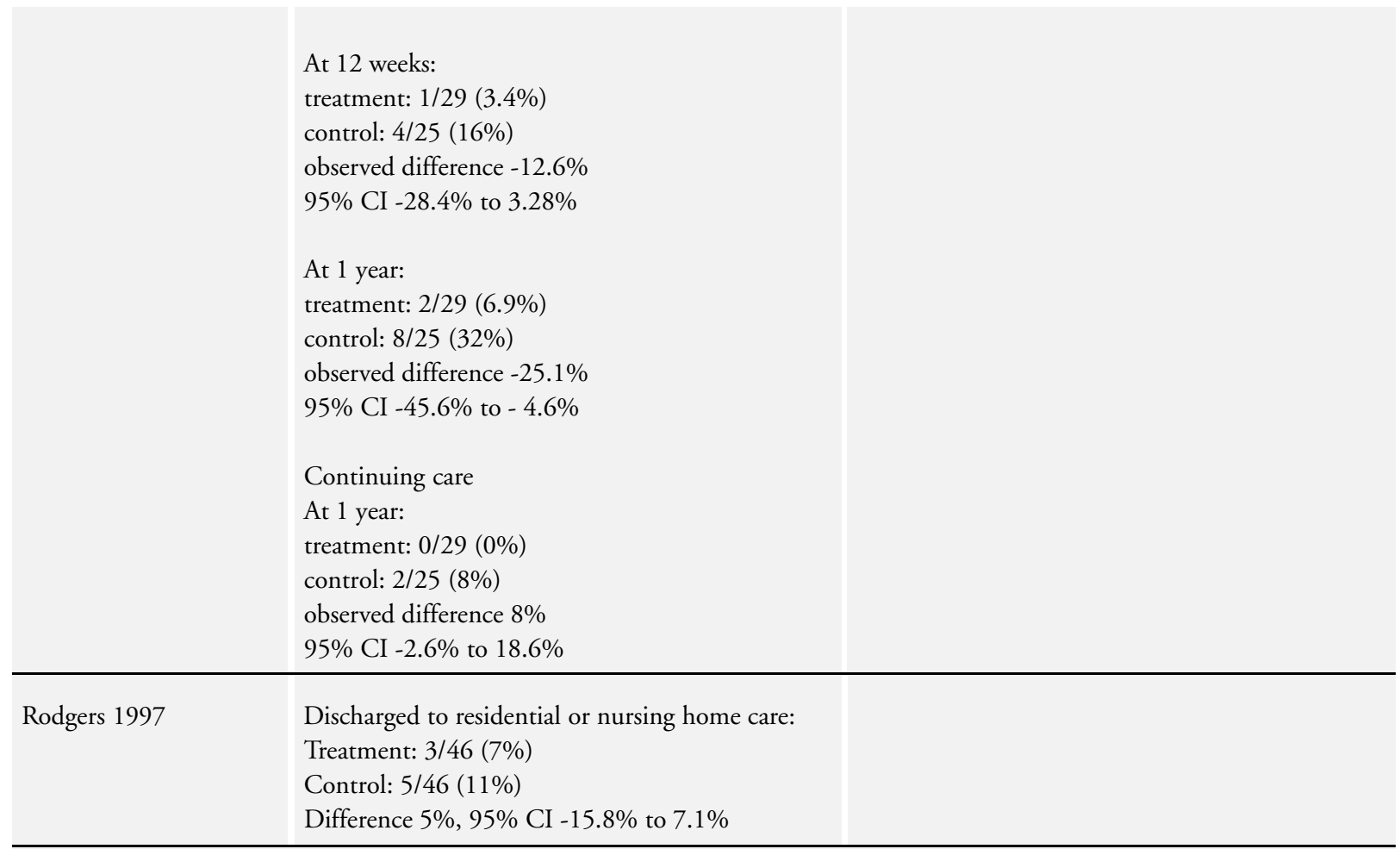

\section{Hospital at home length of stay}

\begin{tabular}{l|l} 
Anderson 2000 & $\begin{array}{l}\text { Length of home based rehabilitation Median } \\
\mathrm{T}=5 \text { weeks (range } 1 \text { to } 19 \text { weeks) }\end{array}$ \\
\hline Cunliffe 2004 & $\begin{array}{l}\text { Median (IQR) visits from EDRS (mean) } \\
\mathrm{T}=8 \text { IQR } 5 \text { to } 31 \text { (22) }\end{array}$ \\
\hline $\begin{array}{l}\text { Median IQR (mean) length of stay from random- } \\
\text { ization to discharge } \\
\mathrm{T}=6 \mathrm{IQR} 4 \text { to } 13(12)\end{array}$ \\
\hline
\end{tabular}

Rodgers 1997 Median hospital at home length of stay: 9 weeks [range 1 to 44 weeks]

$\begin{array}{ll}\text { Skwarska } 2000 & \text { Hospital at home visits: } \\ \text { Mean } 3.8 \text { per patient }\end{array}$

Total length of stay - hospital plus hospital at home

\begin{tabular}{ll}
\hline Harris 2005 & Total length of stay (IPD) \\
& $\mathrm{T}=23.5 \mathrm{SD} 15.6$ \\
$\mathrm{C}=17.7 \mathrm{SD} 18.3$ \\
difference 5.76 days, $95 \%$ CI 1.11 to $10.4, \mathrm{p}<0.02$
\end{tabular}


Published data for older patients with a mix of conditions and those recovering from a stroke (Continued)

\begin{tabular}{|c|c|c|}
\hline Richards 1998 & $\begin{array}{l}\text { Total length of stay for patients with a medical con- } \\
\text { dition: } \\
\text { Treatment }(\mathrm{n}=50): 53.8(26.59) \\
\text { Control }(\mathrm{n}=25): 50.12(23.11) \\
\text { Difference } 3.68 \text { days, } \\
95 \% \text { CI }-8.77 \text { to } 16.1\end{array}$ & \\
\hline Shepperd 1998 & $\begin{array}{l}\text { Total days of care (hospital plus hospital at home): } \\
\text { Elderly medical } \\
\text { treatment: } 21.88 \text { (18.30) } \\
\text { control: } 13.20 \text { (14.19) } \\
\text { difference } 8.67 \\
95 \% \text { CI } 1.90 \text { to } 15.45 \\
\text { Chronic obstructive airways disease } \\
\text { treatment: } 12.27 \text { (3.69) } \\
\text { control: } 12.12(7.49) \\
\text { difference } 0.15 \\
95 \% \text { CI }-4.21 \text { to } 4.51\end{array}$ & \\
\hline \multicolumn{3}{|l|}{ Falls } \\
\hline Anderson 2000 & $\begin{array}{l}\text { Falls at } 6 \text { months } \\
\mathrm{T}=5 / 42(12 \%) \\
\mathrm{C}=7 / 44(16 \%) \\
\mathrm{P}=0.8295 \% \mathrm{CI}-18.6,10.6\end{array}$ & \\
\hline Harris 2005 & $\begin{array}{l}\text { Falls } \\
\text { Days 0-10 } \\
\mathrm{T}=11 / 143(8.1 \%) \\
\mathrm{C}=8 / 142(5.6 \%) \\
\text { Days } 11-30 \\
\mathrm{~T}=8 / 143(6.2 \%) \\
\mathrm{C}=6 / 142(4.8 \%) \\
\text { Days } 31-90 \\
\mathrm{~T}=14 / 143(10.9 \%) \\
\mathrm{C}=18 / 142(14.4 \%) \\
\text { Total falls by } 3 \text { months: } \\
\mathrm{T}=33 / 143(23 \%) \\
\mathrm{C}=32 / 142(22.5 \%)\end{array}$ & \\
\hline Widen-Holmqvist 1998 & $\begin{array}{l}\text { Falls (non recurrent): } \\
\text { Treatment: } 10 / 41(24.4 \%) \\
\text { Control: } 6 / 40(15 \%) \\
\text { Difference } 9.4 \%, 95 \% \text { CI }-7.8 \% \text { to } 26.6 \%\end{array}$ & 2 falls in treatment group resulted in a fracture \\
\hline
\end{tabular}


Analysis I.2. Comparison I Hospital at home versus in-patient care, Outcome 2 Mortality at 3 months older people with a mix of conditions.

Review: Hospital at home early discharge

Comparison: I Hospital at home versus in-patient care

Outcome: 2 Mortality at 3 months - older people with a mix of conditions

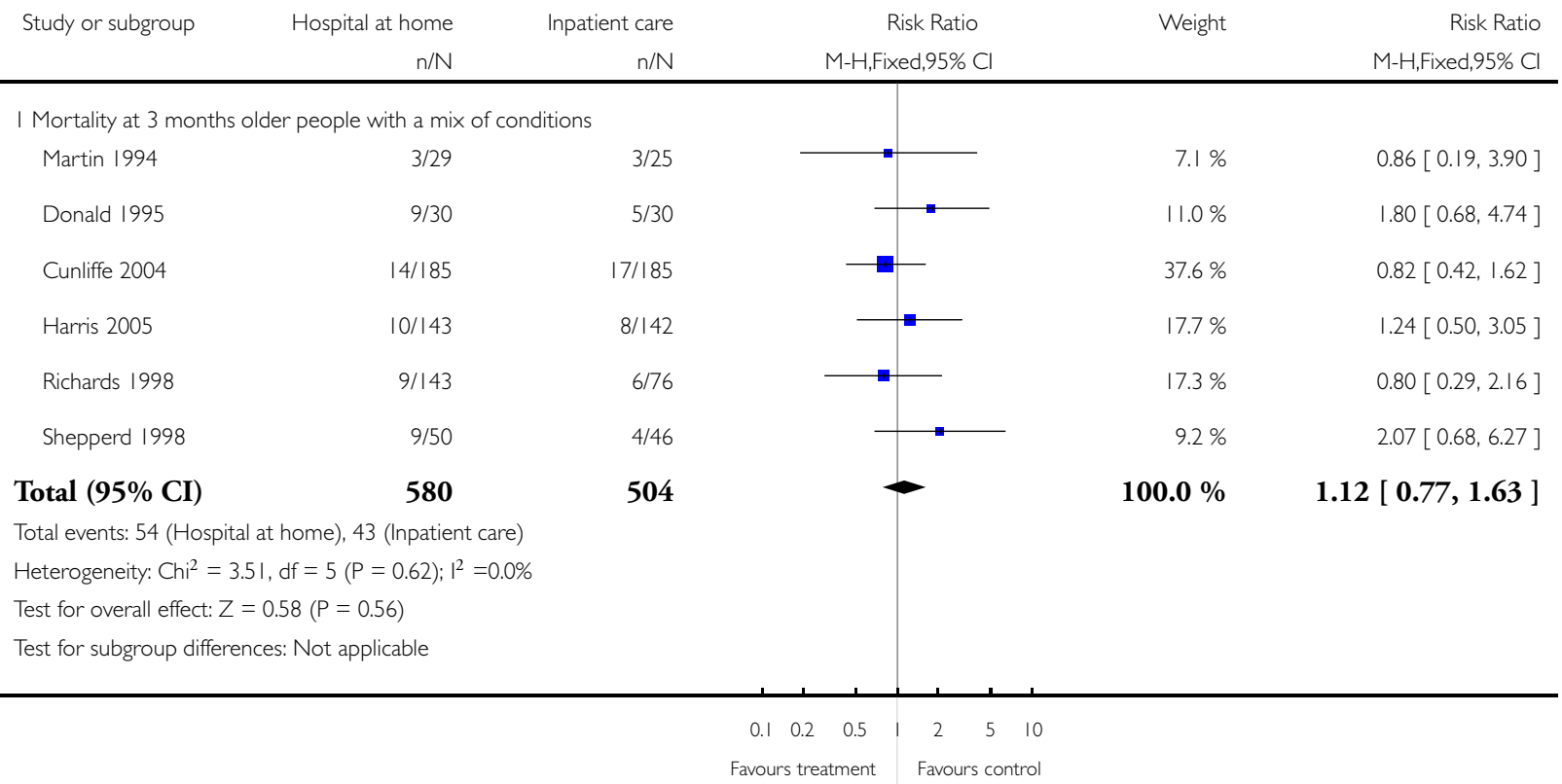

Analysis I.3. Comparison I Hospital at home versus in-patient care, Outcome 3 Mortality at 6 months older people with a medical condition requiring geriatric rehabilitation.

Review: Hospital at home early discharge

Comparison: I Hospital at home versus in-patient care

Outcome: 3 Mortality at 6 months - older people with a medical condition requiring geriatric rehabilitation

\begin{tabular}{|c|c|c|c|c|c|}
\hline \multirow[t]{2}{*}{ Study or subgroup } & Hospital at home & Inpatient care & Risk Ratio & Weight & Risk Ratio \\
\hline & $\mathrm{n} / \mathrm{N}$ & $\mathrm{n} / \mathrm{N}$ & M-H,Fixed,95\% Cl & & M-H,Fixed,95\% Cl \\
\hline Caplan 2006 & $15 / 70$ & $7 / 34$ & + & $100.0 \%$ & $1.04[0.47,2.31]$ \\
\hline Total (95\% CI) & 70 & 34 & & $100.0 \%$ & $1.04[0.47,2.31]$ \\
\hline \multicolumn{6}{|c|}{ Total events: I5 (Hospital at home), 7 (Inpatient care) } \\
\hline \multicolumn{6}{|c|}{ Heterogeneity: not applicable } \\
\hline \multicolumn{6}{|c|}{ Test for overall effect: $Z=0.10(P=0.92)$} \\
\hline Test for subgroup diffe & s: Not applicable & & & & \\
\hline
\end{tabular}

Favours treatment Favours control 
Analysis I.4. Comparison I Hospital at home versus in-patient care, Outcome 4 Mortality at 3 months patients recovering from a stroke.

Review: Hospital at home early discharge

Comparison: I Hospital at home versus in-patient care

Outcome: 4 Mortality at 3 months - patients recovering from a stroke

\begin{tabular}{|c|c|c|c|c|c|c|}
\hline \multirow{3}{*}{$\begin{array}{l}\text { Study or subgroup } \\
\text { Bautz-Holter } 2002\end{array}$} & \multirow{2}{*}{$\begin{array}{r}\text { Hospital at home } \\
n / N\end{array}$} & \multirow{2}{*}{$\begin{array}{r}\text { Inpatient care } \\
n / N\end{array}$} & \multicolumn{2}{|c|}{ Risk Ratio } & Weight & Risk Ratio \\
\hline & & & \multicolumn{2}{|c|}{ M-H,Fixed,95\% Cl } & & M-H,Fixed,95\% Cl \\
\hline & $2 / 42$ & $3 / 40$ & $\longrightarrow$ & & $27.5 \%$ & $0.63[0.11,3.60]$ \\
\hline Cunliffe 2004 & $3 / 43$ & | /44 & & & $8.8 \%$ & $3.07[0.33,28.37]$ \\
\hline Manchester FASTER & $1 / 12$ & $2 / 11$ & $\longleftarrow$ & & $18.7 \%$ & $0.46[0.05,4.38]$ \\
\hline Mayo 2000 & $2 / 58$ & $0 / 56$ & & & $4.5 \%$ & $4.83[0.24,98.44]$ \\
\hline Rodgers 1997 & $1 / 46$ & $4 / 46$ & $\longleftrightarrow$ & & $35.8 \%$ & $0.25[0.03,2.15]$ \\
\hline Shepperd 1998 & $2 / 11$ & $0 / 10$ & & & $4.7 \%$ & $4.58[0.25,85.33]$ \\
\hline Total (95\% CI) & 212 & 207 & & & $100.0 \%$ & $1.05[0.48,2.34]$ \\
\hline \multicolumn{7}{|c|}{ Total events: II (Hospital at home), I0 (Inpatient care) } \\
\hline \multicolumn{7}{|c|}{ Heterogeneity: $\mathrm{Ch}^{2}=5.4 \mathrm{I}, \mathrm{df}=5(\mathrm{P}=0.37) ; \mathrm{I}^{2}=7 \%$} \\
\hline \multicolumn{7}{|c|}{ Test for overall effect: $Z=0.13(P=0.90)$} \\
\hline \multicolumn{7}{|c|}{ Test for subgroup differences: Not applicable } \\
\hline
\end{tabular}


Analysis I.5. Comparison I Hospital at home versus in-patient care, Outcome 5 Mortality at 6 months patients recovering from a stroke.

Review: Hospital at home early discharge

Comparison: I Hospital at home versus in-patient care

Outcome: 5 Mortality at 6 months - patients recovering from a stroke

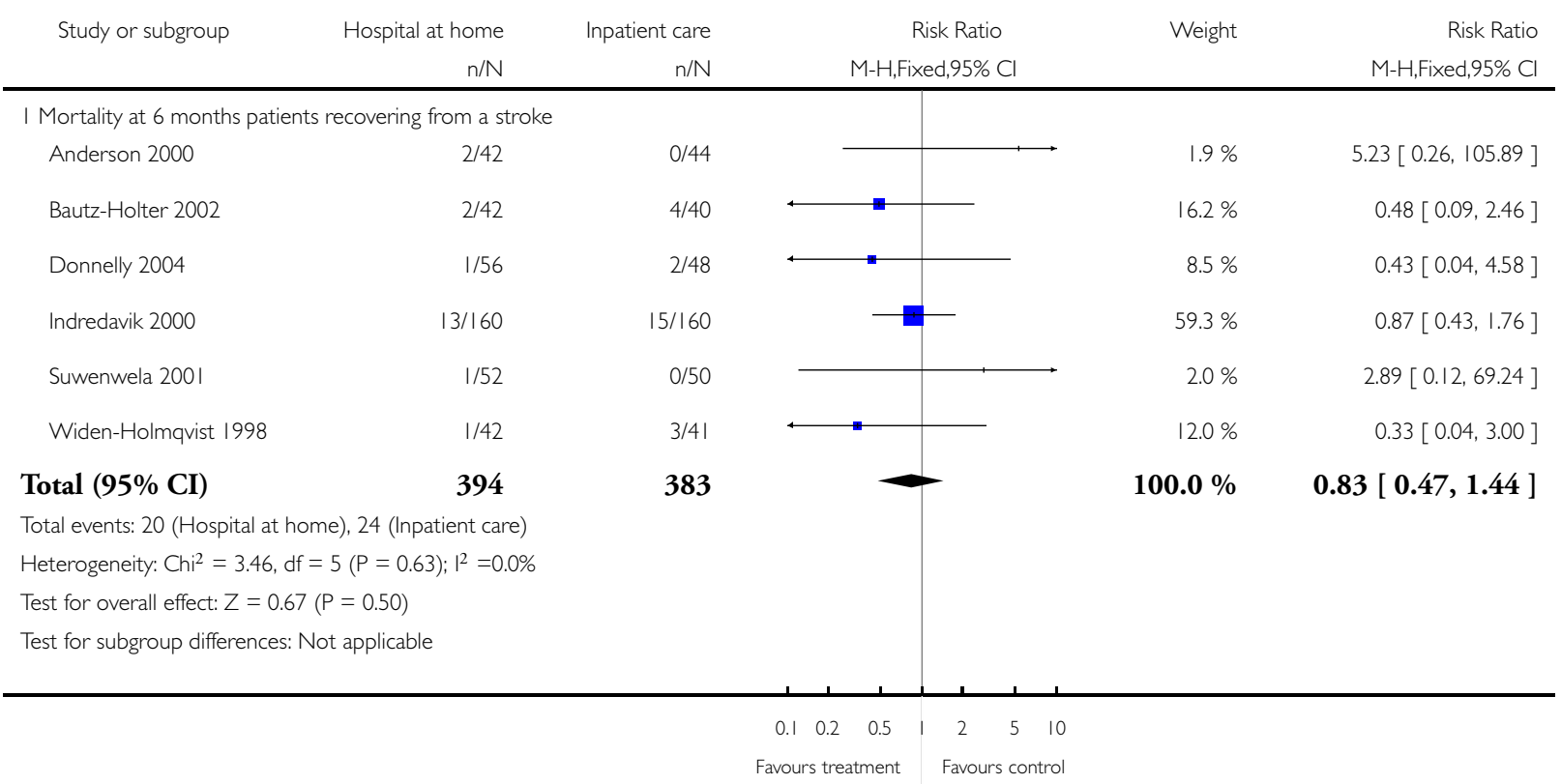


Analysis I.6. Comparison I Hospital at home versus in-patient care, Outcome 6 Mortality at I year patients recovering from a stroke.

Review: Hospital at home early discharge

Comparison: I Hospital at home versus in-patient care

Outcome: 6 Mortality at I year - patients recovering from a stroke

\begin{tabular}{|c|c|c|c|c|c|}
\hline \multirow[t]{2}{*}{ Study or subgroup } & \multirow{2}{*}{$\begin{array}{r}\text { Hospital at home } \\
n / N\end{array}$} & \multirow{2}{*}{$\begin{array}{r}\text { Inpatient care } \\
n / N\end{array}$} & Risk Ratio & \multirow[t]{2}{*}{ Weight } & \multirow{2}{*}{$\begin{array}{r}\text { Risk Ratio } \\
\text { M-H,Fixed,95\% Cl }\end{array}$} \\
\hline & & & $\mathrm{M}-\mathrm{H}$, Fixed,95\% Cl & & \\
\hline Askim 2004 & $8 / 31$ & $5 / 31$ & 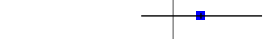 & $11.5 \%$ & $1.60[0.59,4.35]$ \\
\hline Cunliffe 2004 & $6 / 43$ & $1 / 44$ & & $2.3 \%$ & $6.14[0.77,48.89]$ \\
\hline Donnelly 2004 & $2 / 59$ & $3 / 54$ & - & $7.2 \%$ & $0.61[0.11,3.51]$ \\
\hline Rudd 1997 & $26 / 167$ & $34 / 164$ & & $79.0 \%$ & $0.75[0.47,1.19]$ \\
\hline Total $(95 \% \mathrm{CI})$ & 300 & 293 & & $100.0 \%$ & $0.96[0.65,1.42]$ \\
\hline \multicolumn{6}{|c|}{ Total events: 42 (Hospital at home), 43 (Inpatient care) } \\
\hline \multicolumn{6}{|c|}{ Heterogeneity: $\mathrm{Chi}^{2}=5.42, \mathrm{df}=3(P=0.14) ; 1^{2}=45 \%$} \\
\hline \multicolumn{6}{|c|}{ Test for overall effect: $Z=0.20(P=0.84)$} \\
\hline \multicolumn{6}{|c|}{ Test for subgroup differences: Not applicable } \\
\hline
\end{tabular}

Analysis I.7. Comparison I Hospital at home versus in-patient care, Outcome 7 Mortality - chronic obstructive airways disease.

Review: Hospital at home early discharge

Comparison: I Hospital at home versus in-patient care

Outcome: 7 Mortality - chronic obstructive airways disease

\begin{tabular}{|c|c|c|c|c|c|}
\hline \multirow[t]{2}{*}{ Study or subgroup } & Hospital at home & Inpatient care & Risk Ratio & Weight & Risk Ratio \\
\hline & $n / N$ & $\mathrm{n} / \mathrm{N}$ & \multicolumn{2}{|l|}{ M-H,Fixed,95\% Cl } & M-H,Fixed,95\% Cl \\
\hline \multicolumn{6}{|c|}{ I Mortality at 2 to 3 months chronic obstructive airways disease } \\
\hline Cotton 2002 & $|/ 4|$ & $2 / 40$ & & $12.8 \%$ & $0.49[0.05,5.17]$ \\
\hline Ojoo 2002 & $1 / 30$ & $3 / 30$ & & $19.0 \%$ & $0.33[0.04,3.03]$ \\
\hline Shepperd 1998 & $3 / 15$ & $3 / 17$ & & $17.8 \%$ & $1.13[0.27,4.79]$ \\
\hline Skwarska 2000 & $4 / 122$ & $6 / 62$ & & $50.4 \%$ & $0.34[0.10,1.16]$ \\
\hline Total $(95 \% \mathrm{CI})$ & 208 & 149 & & $100.0 \%$ & $0.50[0.23,1.09]$ \\
\hline \multicolumn{6}{|c|}{ Total events: 9 (Hospital at home), I 4 (Inpatient care) } \\
\hline \multicolumn{6}{|c|}{ Heterogeneity: Chi $^{2}=1.75, d f=3(P=0.62) ;\left.\right|^{2}=0.0 \%$} \\
\hline \multicolumn{6}{|c|}{ Test for overall effect: $Z=1.74(P=0.082)$} \\
\hline Test for subgroup diff & : Not applicable & & & & \\
\hline
\end{tabular}

$\begin{array}{lllllll}0.1 & 0.2 & 0.5 & 1 & 2 & 5 & 10\end{array}$

Favours treatment Favours control

Copyright (C) 20II The Cochrane Collaboration. Published by John Wiley \& Sons, Ltd. 


\section{Analysis I.8. Comparison I Hospital at home versus in-patient care, Outcome 8 Readmission to hospital at}

3 months - older people with a mix of conditions.

Review: Hospital at home early discharge

Comparison: I Hospital at home versus in-patient care

Outcome: 8 Readmission to hospital at 3 months - older people with a mix of conditions

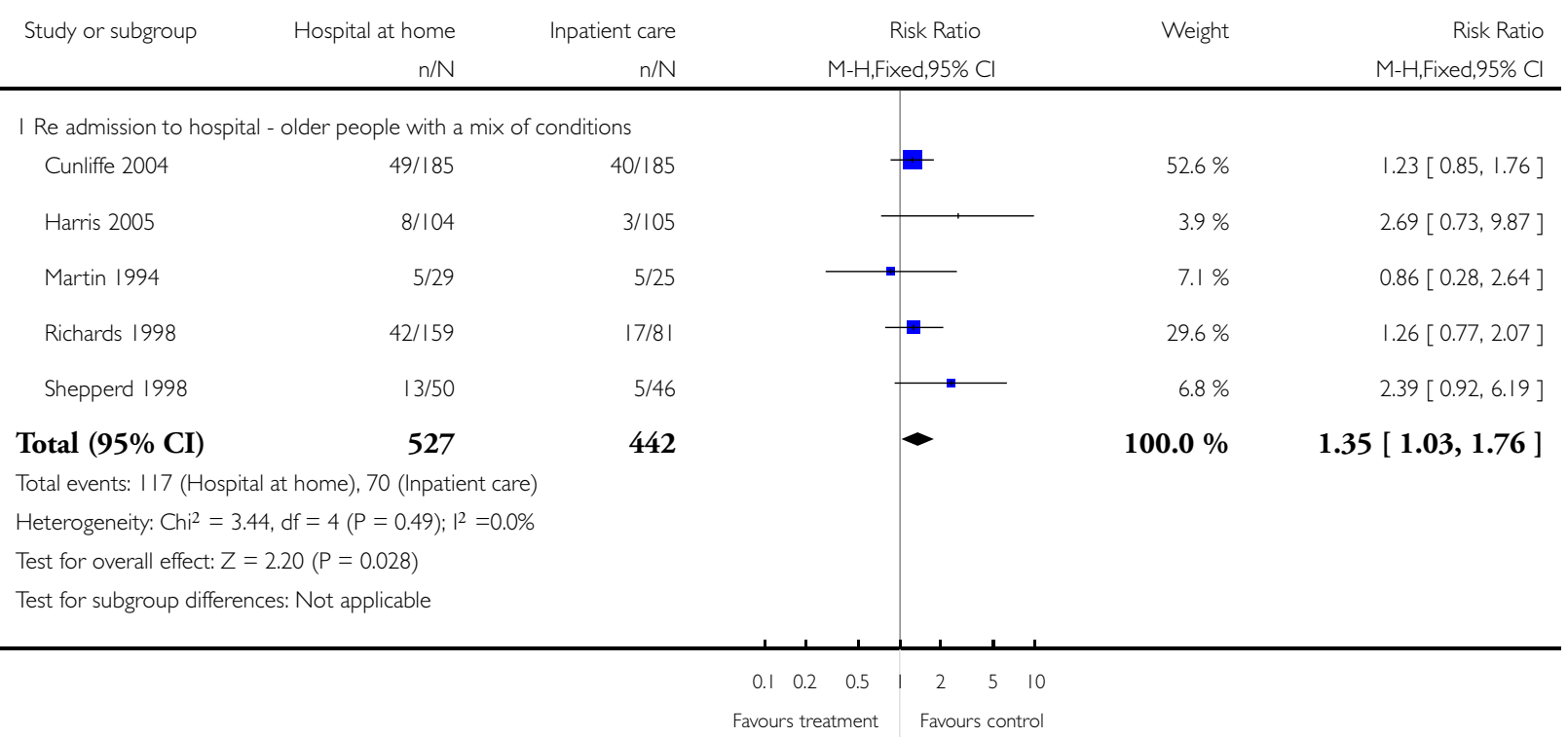


Analysis I.9. Comparison I Hospital at home versus in-patient care, Outcome 9 Readmissions at 3 months - those recovering from a stroke.

Review: Hospital at home early discharge

Comparison: I Hospital at home versus in-patient care

Outcome: 9 Readmissions at 3 months - those recovering from a stroke

\begin{tabular}{|c|c|c|c|c|c|}
\hline \multirow[t]{2}{*}{ Study or subgroup } & Hospital at home & Inpatient care & Risk Ratio & \multirow[t]{2}{*}{ Weight } & \multirow{2}{*}{$\begin{array}{r}\text { Risk Ratio } \\
\text { M-H,Fixed,95\% Cl }\end{array}$} \\
\hline & $\mathrm{n} / \mathrm{N}$ & $\mathrm{n} / \mathrm{N}$ & M-H,Fixed,95\% Cl & & \\
\hline \multicolumn{6}{|c|}{ I Re admission to hospital for patients recovering from a stroke at 3 months follow-up } \\
\hline Bautz-Holter 2002 & $2 / 34$ & $4 / 32$ & + & $40.5 \%$ & $0.47[0.09,2.40]$ \\
\hline Rodgers 1997 & $5 / 46$ & $5 / 46$ & & $49.2 \%$ & $1.00[0.31,3.22]$ \\
\hline Shepperd 1998 & $4 / 11$ & $1 / 10$ & & $10.3 \%$ & $3.64[0.48,27.33]$ \\
\hline Total $(95 \% \mathrm{CI})$ & 91 & 88 & & $100.0 \%$ & $1.06[0.47,2.38]$ \\
\hline \multicolumn{6}{|c|}{ Total events: II (Hospital at home), I0 (Inpatient care) } \\
\hline \multicolumn{6}{|c|}{ Heterogeneity: $\mathrm{Chi}^{2}=2.40, \mathrm{df}=2(P=0.30) ;\left.\right|^{2}=17 \%$} \\
\hline \multicolumn{6}{|c|}{ Test for overall effect: $Z=0.13(P=0.89)$} \\
\hline Test for subgroup diffe & Not applicable & & & & \\
\hline
\end{tabular}

$\begin{array}{lllllll}0.1 & 0.2 & 0.5 & 1 & 2 & 5 & 10\end{array}$

Favours treatment Favours control

Analysis I.10. Comparison I Hospital at home versus in-patient care, Outcome I0 Readmissions at 6 months - those recovering from a stroke.

Review: Hospital at home early discharge

Comparison: I Hospital at home versus in-patient care

Outcome: 10 Readmissions at 6 months - those recovering from a stroke

\begin{tabular}{|c|c|c|c|c|c|}
\hline \multirow[t]{2}{*}{ Study or subgroup } & Hospital at home & Inpatient care & Risk Ratio & Weight & Risk Ratio \\
\hline & $\mathrm{n} / \mathrm{N}$ & $\mathrm{n} / \mathrm{N}$ & \multicolumn{2}{|l|}{ M-H,Fixed,95\% Cl } & M-H,Fixed,95\% Cl \\
\hline \multicolumn{6}{|c|}{ I Readmission at 6 months - those recovering from a stroke } \\
\hline Anderson 2000 & $15 / 42$ & $11 / 44$ & + & $41.2 \%$ & $1.43[0.74,2.75]$ \\
\hline Bautz-Holter 2002 & $3 / 34$ & $4 / 31$ & 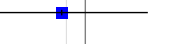 & $16.1 \%$ & $0.68[0.17,2.82]$ \\
\hline Widen-Holmqvist 1998 & $8 / 41$ & $11 / 40$ & 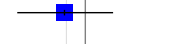 & $42.7 \%$ & $0.71[0.32,1.58]$ \\
\hline Total (95\% CI) & 117 & 115 & $>$ & $100.0 \%$ & $1.00[0.63,1.60]$ \\
\hline \multicolumn{6}{|c|}{ Total events: 26 (Hospital at home), 26 (Inpatient care) } \\
\hline \multicolumn{6}{|c|}{ Heterogeneity: $\mathrm{Chi}^{2}=2.13, \mathrm{df}=2(\mathrm{P}=0.35) ; \mathrm{I}^{2}=6 \%$} \\
\hline \multicolumn{6}{|c|}{ Test for overall effect: $Z=0.01(P=0.99)$} \\
\hline Test for subgroup difference & t applicable & & & & \\
\hline
\end{tabular}

Favours treatment Favours control

Copyright (C) 20II The Cochrane Collaboration. Published by John Wiley \& Sons, Ltd. 
Analysis I.I I. Comparison I Hospital at home versus in-patient care, Outcome I I Readmission at I year for those recovering from a stroke.

Review: Hospital at home early discharge

Comparison: I Hospital at home versus in-patient care

Outcome: II Readmission at I year for those recovering from a stroke

\begin{tabular}{|c|c|c|c|c|c|}
\hline \multirow[t]{2}{*}{ Study or subgroup } & Hospital at home & Inpatient care & Risk Ratio & \multirow[t]{2}{*}{ Weight } & \multirow{2}{*}{$\begin{array}{r}\text { Risk Ratio } \\
\text { M-H,Fixed,95\% Cl }\end{array}$} \\
\hline & $\mathrm{n} / \mathrm{N}$ & $\mathrm{n} / \mathrm{N}$ & M-H,Fixed,95\% Cl & & \\
\hline Donnelly 2004 & $6 / 59$ & $7 / 54$ & $\longrightarrow$ & $14.7 \%$ & $0.78[0.28,2.19]$ \\
\hline Rudd 1997 & $44 / 167$ & $42 / 164$ & & $85.3 \%$ & $1.03[0.72,1.48]$ \\
\hline Total $(95 \% \mathrm{CI})$ & 226 & 218 & & $100.0 \%$ & $0.99[0.70,1.40]$ \\
\hline \multicolumn{6}{|c|}{ Total events: 50 (Hospital at home), 49 (Inpatient care) } \\
\hline \multicolumn{6}{|c|}{ Heterogeneity: $\mathrm{Ch}^{2}=0.24, \mathrm{df}=\mathrm{I}(\mathrm{P}=0.62) ; \mathrm{I}^{2}=0.0 \%$} \\
\hline \multicolumn{6}{|c|}{ Test for overall effect: $Z=0.04(P=0.97)$} \\
\hline \multicolumn{6}{|c|}{ Test for subgroup differences: Not applicable } \\
\hline
\end{tabular}


Analysis I.I2. Comparison I Hospital at home versus in-patient care, Outcome 12 Readmission for those with COPD.

Review: Hospital at home early discharge

Comparison: I Hospital at home versus in-patient care

Outcome: 12 Readmission for those with COPD

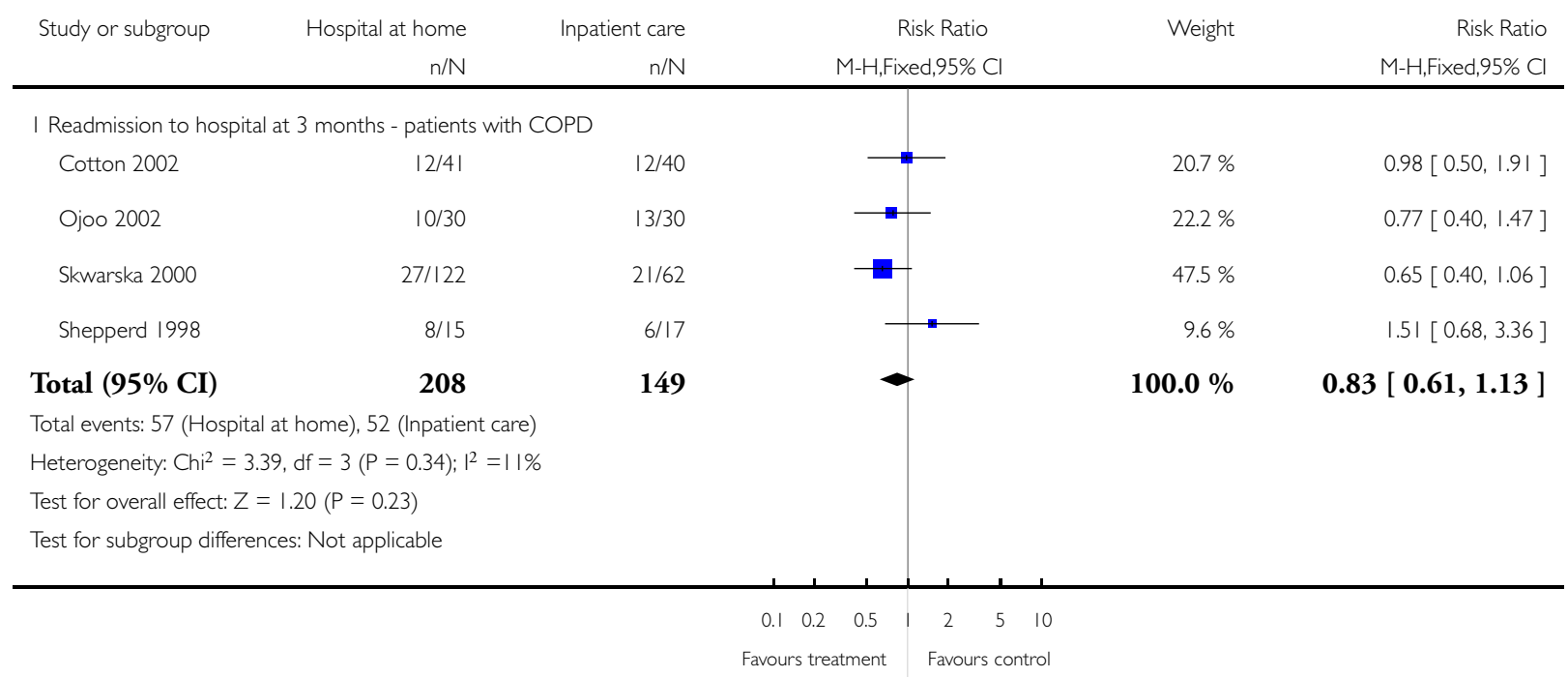

Analysis I.13. Comparison I Hospital at home versus in-patient care, Outcome I3 Functional ability at 3 months - older people with a mix of conditions.

Review: Hospital at home early discharge

Comparison: I Hospital at home versus in-patient care

Outcome: 13 Functional ability at 3 months - older people with a mix of conditions

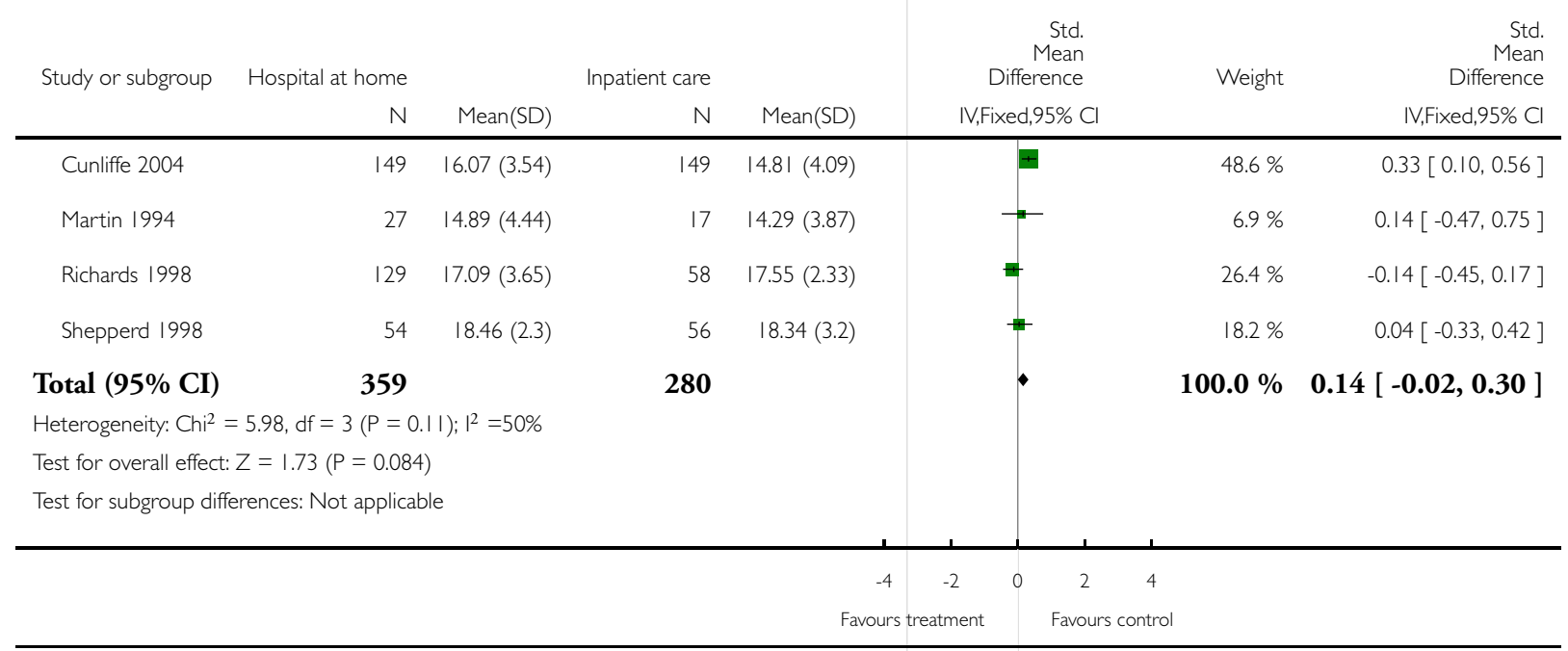


Analysis I.I4. Comparison I Hospital at home versus in-patient care, Outcome I4 Residential care at I year follow up (Donald 6 months) - older patients with a mix of conditions.

Review: Hospital at home early discharge

Comparison: I Hospital at home versus in-patient care

Outcome: 14 Residential care at I year follow up (Donald 6 months) - older patients with a mix of conditions

\begin{tabular}{|c|c|c|c|c|c|}
\hline \multirow[t]{2}{*}{ Study or subgroup } & Hospital at home & Inpatient care & Risk Ratio & Weight & Risk Ratio \\
\hline & $\mathrm{n} / \mathrm{N}$ & $\mathrm{n} / \mathrm{N}$ & M-H,Fixed,95\% Cl & & M-H,Fixed,95\% Cl \\
\hline Cunliffe 2004 & $35 / 185$ & $43 / 185$ & & $76.0 \%$ & $0.81[0.55,1.21]$ \\
\hline Donald 1995 & $2 / 30$ & $5 / 30$ & & $8.8 \%$ & $0.40[0.08,1.90]$ \\
\hline Martin 1994 & $2 / 29$ & $8 / 25$ & $\longleftarrow$ & $15.2 \%$ & $0.22[0.05,0.92]$ \\
\hline Total $(95 \% \mathrm{CI})$ & 244 & 240 & & $100.0 \%$ & $0.69[0.48,0.99]$ \\
\hline \multicolumn{6}{|c|}{ Total events: 39 (Hospital at home), 56 (Inpatient care) } \\
\hline \multicolumn{6}{|c|}{ Heterogeneity: $\mathrm{Chi}^{2}=3.61, \mathrm{df}=2(P=0.16) ; \mathrm{I}^{2}=45 \%$} \\
\hline \multicolumn{6}{|c|}{ Test for overall effect: $Z=2.01$ ( $P=0.044)$} \\
\hline Test for subgroup diff & s: Not applicable & & & & \\
\hline
\end{tabular}

$\begin{array}{lllllll}0.1 & 0.2 & 0.5 & 1 & 2 & 5 & 10\end{array}$

Favours treatment Favours control 
Analysis I.I5. Comparison I Hospital at home versus in-patient care, Outcome I 5 Residential care at 6 months follow up (Rodgers 3 month data) - recovering from a stroke.

Review: Hospital at home early discharge

Comparison: I Hospital at home versus in-patient care

Outcome: 15 Residential care at 6 months follow up (Rodgers 3 month data) - recovering from a stroke

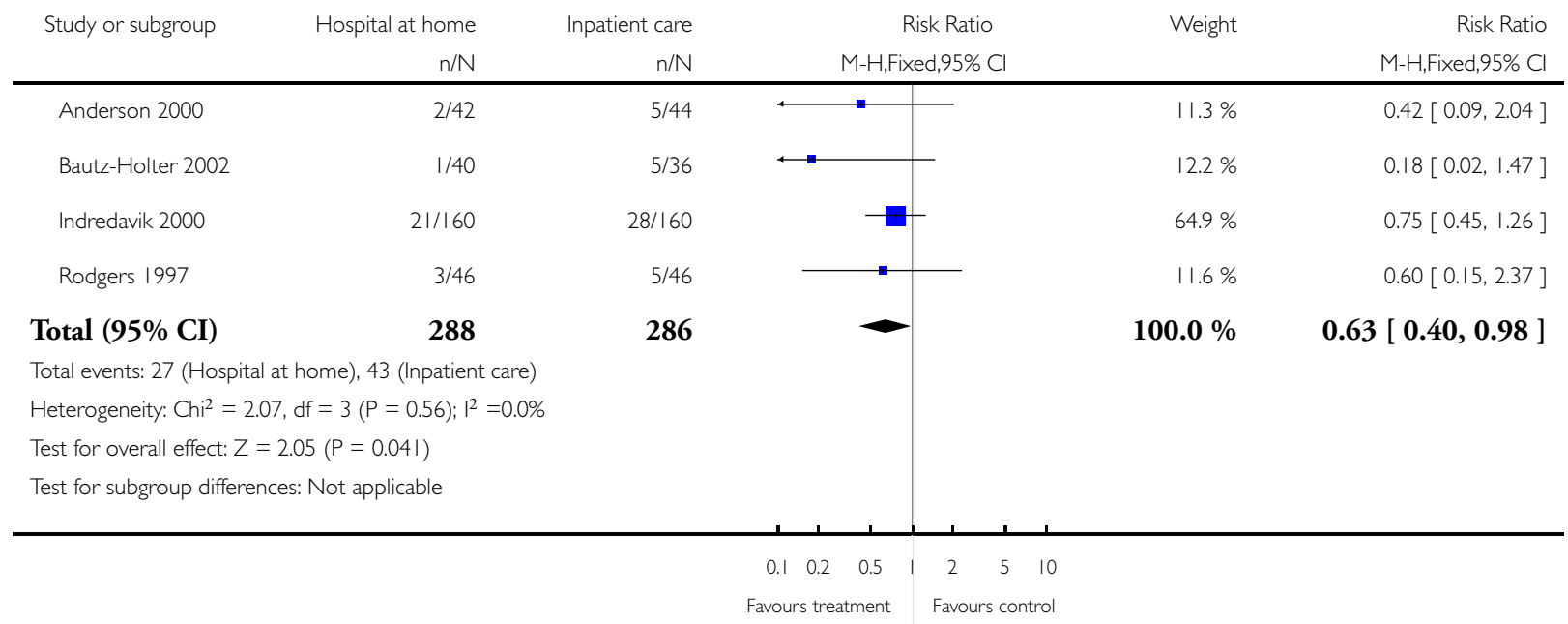

Analysis I.16. Comparison I Hospital at home versus in-patient care, Outcome 16 Hospital length of stay older people with a mix of conditions.

Review: Hospital at home early discharge

Comparison: I Hospital at home versus in-patient care

Outcome: 16 Hospital length of stay - older people with a mix of conditions

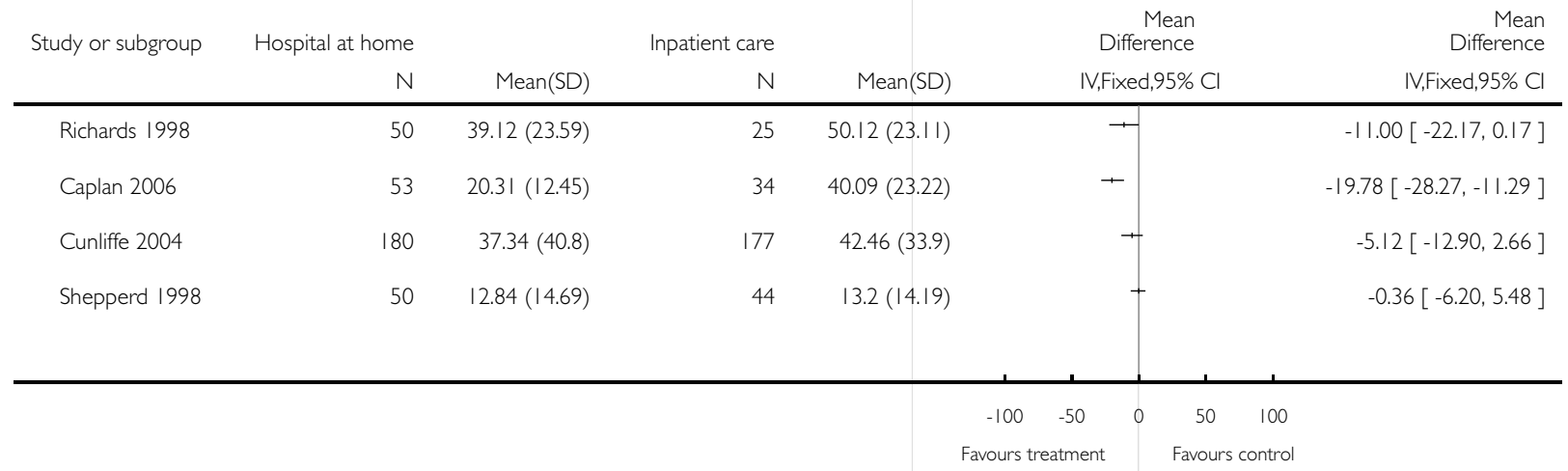


Analysis I.17. Comparison I Hospital at home versus in-patient care, Outcome 17 Hospital length of stay those recovering from a stroke.

Review: Hospital at home early discharge

Comparison: I Hospital at home versus in-patient care

Outcome: 17 Hospital length of stay - those recovering from a stroke

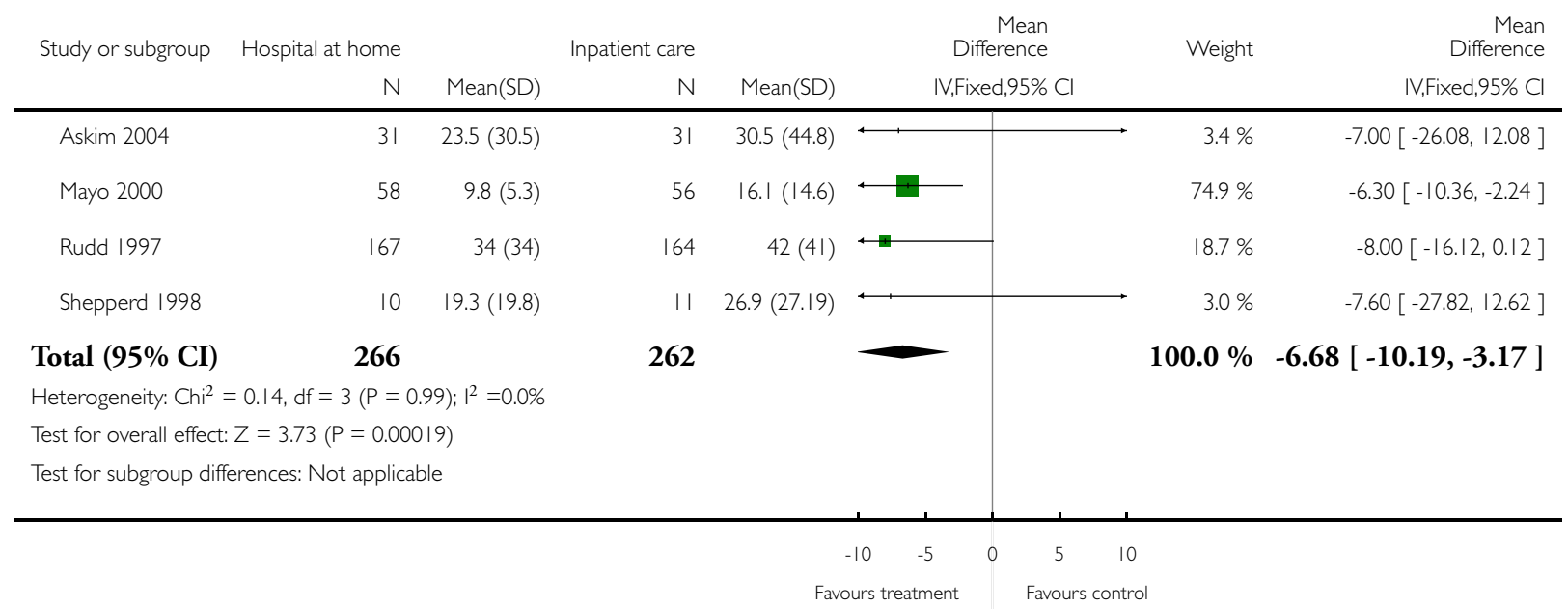

Analysis I.18. Comparison I Hospital at home versus in-patient care, Outcome 18 Hospital length of stay patients with chronic obstructive pulmonary disease.

Review: Hospital at home early discharge

Comparison: I Hospital at home versus in-patient care

Outcome: 18 Hospital length of stay - patients with chronic obstructive pulmonary disease

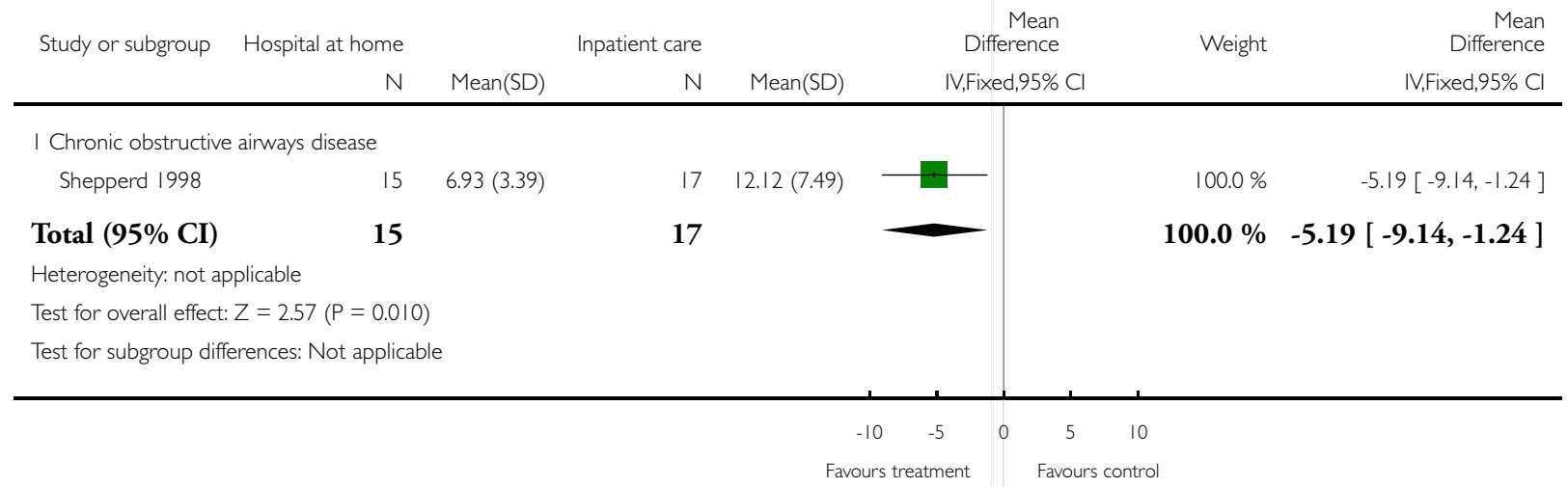




\section{Analysis I.19. Comparison I Hospital at home versus in-patient care, Outcome 19 Total length of stay -}

older people with a mix of mainly medical conditions.

Review: Hospital at home early discharge

Comparison: I Hospital at home versus in-patient care

Outcome: 19 Total length of stay - older people with a mix of mainly medical conditions

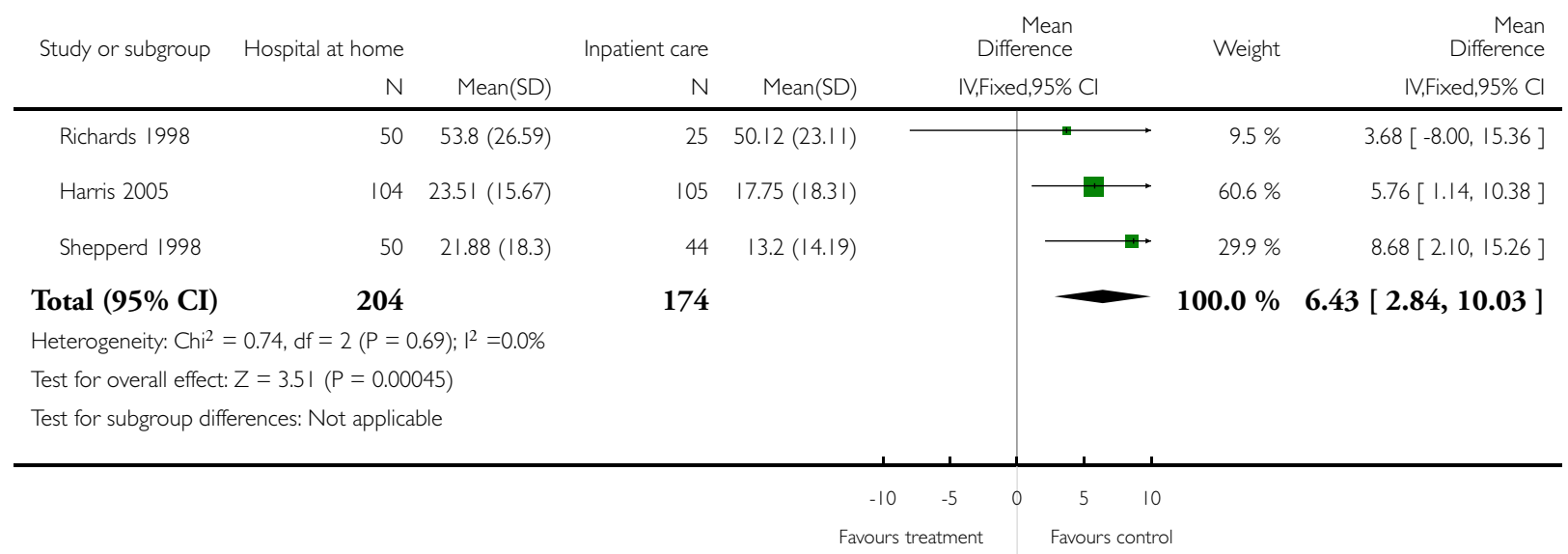

Analysis I.20. Comparison I Hospital at home versus in-patient care, Outcome 20 Early discharge of patients following surgery.

Early discharge of patients following surgery

\begin{tabular}{|c|c|c|}
\hline Study & Results & Notes \\
\hline \multicolumn{3}{|c|}{ Patient outcomes: all clinical complications } \\
\hline Adler 1978 & $\begin{array}{l}\text { All clinical complications: } \\
\text { At } 7 \text { days after surgery: } \\
\text { treatment: } 7 / 56(12.5 \%) \\
\text { control: } 5 / 49(10.2 \%) \\
\text { observed difference: } 2.3 \% \\
95 \% \text { CI }-9.8 \% \text { to } 14 \% \\
\text { Varicose veins } \\
\text { treatment: } 8 / 61(13.1 \%) \\
\text { control: } 0 / 58(0 \%) \\
\text { observed difference: } 13.1 \% \\
95 \% \text { CI } 5 \% \text { to } 22 \%\end{array}$ & Hernia \\
\hline Booth 2004 & $\begin{array}{l}\text { In hospital clinical events } \\
\mathrm{T}=20 / 65(30 \%) \\
\mathrm{C}=8 / 32(25 \%) \\
\mathrm{P}=0.55\end{array}$ & \\
\hline
\end{tabular}


Early discharge of patients following surgery (Continued)

\begin{tabular}{l|l|l}
\hline Ruckley 1978 & All clinical complications: & Conditions were combined \\
& At $2-3$ weeks: & \\
& treatment: $27 / 117(23.1 \%)$ & \\
& control: $17 / 121(14 \%)$ & \\
observed difference: $9.1 \%$ & \\
$95 \%$ CI $-19 \%$ to $1 \%$ & \\
\hline
\end{tabular}

\section{Patient outcomes: mortality}

\begin{tabular}{ll}
\hline Richards 1998 & Mortality: \\
& Treatment: $12 / 60(7.5 \%)$ \\
& Control: $6 / 81(7.4 \%)$ \\
& {$[0.1 \%,-7 \%$ to $7 \%]$} \\
\hline
\end{tabular}

\begin{tabular}{|l|l|}
\hline Shepperd 1998 & Mortality: \\
& At 3 months: \\
\hline Hip replacements: & Treatment: $0 / 37$ \\
& Control: $1 / 49$ \\
& Knee replacements: \\
Treatment: $0 / 47$ \\
Control: $0 / 39$ \\
\hline Hysterectomy: \\
Treatment: $0 / 114$ \\
Control: $0 / 124$ \\
\hline
\end{tabular}

\section{Patient outcomes: functional status}

\begin{tabular}{|c|c|c|}
\hline Crotty 2002 & $\begin{array}{l}\text { Functional status at } 4 \text { months (median change from } \\
\text { baseline, } 25 \text { th } \& 75 \text { th percentile): } \\
\text { Modified Barthel Index } \\
\text { treatment: } 11.00 \text { (5.5 to } 16.0) \\
\text { Control: } 8.0 \text { (-2.5 to } 13.5) \\
\text { median difference in change score } 3.00 \\
\text { p }<0.05 \\
\text { Falls efficacy scale (median, } 25 \text { th } \& 75 \text { th percentile) } \\
\text { treatment: } 90.5 \text { ( } 80.5 \text { to } 98) \text { control: } 79.5 \text { ( } 40.0 \text { to } 92 . \\
\text { 5) } \\
\text { p }<0.05 \\
\text { SF36 Physical component scale: (median change from } \\
\text { baseline, } 25 \text { th \& } 75 \text { th percentile) treatment: }-3.4 \text { (-14. } \\
9 \text { to } 8.1 \text { ) } \\
\text { control: }-3.9 \text { (-19.5 to } 11.7 \text { ) } \\
\text { SF36 Mental Component Scale: (median change from }\end{array}$ & SF36 PCS \\
\hline
\end{tabular}




\section{Early discharge of patients following surgery (Continued)}

baseline, 25 th $\& 75$ th percentile)

treatment: 0.01 control: -11.7 (-23.4 to 0.05$)$

\begin{tabular}{|c|c|c|}
\hline Palmer Hill 2000 & $\begin{array}{l}\text { change from baseline, } 25 \text { th } \& 75 \text { th percentileno data } \\
\text { reported }\end{array}$ & SF 36 physical component scale, and number of falls \\
\hline Richards 1998 & $\begin{array}{l}\text { Functional status: } \\
\text { At } 3 \text { months follow-up: } \\
\text { Treatment: } 1.9 \\
\text { Control: } 1.7 \\
{[0.17,-0.76 \text { to } 1.10]}\end{array}$ & $\begin{array}{l}\text { Barthel Index: } \\
\text { Scale 0-20 (low score = } \\
\text { high level of dependence) }\end{array}$ \\
\hline
\end{tabular}

Patient outcomes: quality of life

\begin{tabular}{|c|c|c|}
\hline Booth 2004 & $\begin{array}{l}\text { SF-36 PCS at } 12 \text { weeks } \\
\text { Mean (sd) } \\
\mathrm{T}=47.4(11.8) \\
\mathrm{C}=49(11.7) \\
\text { Difference }-0.5,95 \% \mathrm{CI}-5.8 \text { to } 4.8, \mathrm{p}=0.85 \\
\text { SF36 MCS at } 12 \text { weeks } \\
\text { Mean (sd) } \\
\mathrm{T}=48.9(8.2) \\
\mathrm{C}=49.2(8.6) \\
\text { Difference } 0.6,95 \% \mathrm{CI}-2.7 \text { to } 3.8, \mathrm{p}=0.73\end{array}$ & \\
\hline Richards 1998 & $\begin{array}{l}\text { Physical fitness: } \\
\text { At } 3 \text { months follow-up: } \\
\text { [-0.05,-0.28 to } 0.19] \\
\text { Feelings: } \\
\text { At } 3 \text { months follow-up: } \\
\text { [-0.09, }-0.50 \text { to } 0.32] \\
\text { Daily activities: } \\
\text { At } 3 \text { months follow-up: } \\
\text { [-0.04, }-0.47 \text { to } 0.38] \\
\text { Social activities: } \\
\text { At } 3 \text { months follow-up: } \\
\text { [0.07, }-0.38 \text { to } 0.52] \\
\text { Change in health: } \\
\text { At } 3 \text { months follow-up: } \\
\text { [-0.01, }-0.34 \text { to } 0.31] \\
\text { Overall health: } \\
\text { At } 3 \text { months follow-up: } \\
\text { [0.10, }-0.21 \text { to } 0.42]\end{array}$ & $\begin{array}{l}\text { EQ 5D scores: Possible range 5-15 } \\
\text { EQ 5D thermometer: Possible range 0-100 }\end{array}$ \\
\hline
\end{tabular}


Early discharge of patients following surgery (Continued)

\begin{tabular}{|c|c|c|}
\hline & $\begin{array}{l}\text { EQ 5D scores: } \\
\text { At } 3 \text { months: } \\
{[-0.04,-0.13 \text { to } 0.06]} \\
\text { EQ } 5 \text { D thermometer: } \\
\text { At } 3 \text { months: } \\
{[-4.6,-11.0 \text { to } 2.0]}\end{array}$ & \\
\hline Shepperd 1998 & $\begin{array}{l}\text { HIP REPLACEMENT } \\
\text { Physical fitness: } \\
\text { Treatment: } 0.42 \\
\text { Control: } 0.51 \\
-0.09 \text { (-0.48 to } 0.29) \\
\text { Feelings: } \\
\text { Treatment: } 1.03 \\
\text { Control: } 0.78 \\
0.25 \text { (-0.29 to } 0.79) \\
\text { Daily activities: } \\
\text { Treatment: } 1.00 \\
\text { Control: } 0.93 \\
0.07 \text { (-0.39 to } 0.53) \\
\text { Social activities: } \\
\text { Treatment: } 1.43 \\
\text { Control: } 1.02 \\
0.41 \text { (-0.15 to } 0.97) \\
\text { Pain: } \\
\text { Treatment: } 1.54 \\
\text { Control: } 1.69 \\
-0.15 \text { (-0.78 to } 0.49) \\
\text { Change in health: } \\
\text { Treatment: } 0.74 \\
\text { Control: } 0.13 \\
0.61 \text { (0.02 to } 1.20) \\
\text { Overall health: } \\
0.10 \text { (-0.35 to } 0.55) \\
\text { Social support: } \\
\text { Treatment: } 0.26 \\
\text { Control: } 0.40 \\
-0.14 \text { (-0.57 to } 0.28) \\
\text { Quality of life: } \\
\text { - }\end{array}$ & $\begin{array}{l}\text { HIP REPLACEMENT } \\
\text { Dartmouth COOP charts: } \\
\text { Scale } 1-5 \text { (low score }= \\
\text { good quality of life) } \\
\text { Follow up data at } 3 \text { months for: Treatment }=36 \\
\text { Control=45 } \\
\text { * Oxford hip score. Baseline score measured at } 1 \text { month. } \\
\text { Scale } 12-60 \text { (high score = high level of impairment) } \\
\text { KNEE REPLACEMENT } \\
\text { Dartmouth COOP charts: } \\
\text { Scale } 1-5 \text { (low score }= \\
\text { good quality of life) } \\
\text { Follow up data at } 3 \text { months for: Treatment }=45 \\
\text { Control=35 } \\
\text { *Bristol knee score. Baseline score done at } 1 \text { month. } \\
\text { Scale 0-50 (low score = poor level of functioning) } \\
\text { HYSTERECTOMY } \\
\text { Dartmouth COOP charts: } \\
\text { Scale } 1-5 \text { (low score = } \\
\text { good quality of life) } \\
\text { Follow up data at } 3 \text { months for: Treatment }=45 \\
\text { Control=35 }\end{array}$ \\
\hline
\end{tabular}


Early discharge of patients following surgery (Continued)

\author{
Treatment: 0.97 \\ Control: 0.47 \\ $0.50(0.13$ to 0.88$)$
}

Oxford Hip Score *:

Treatment: 4.77

Control: 3.13

$1.64(-1.23$ to 4.5$)$

\title{
KNEE REPLACEMENT
}

Physical fitness:

Treatment: 0.19

Control: 0.29

$-0.10(-0.49$ to 0.29$)$

Feelings:

Treatment: 0.51

Control: 0.37

$0.14(-0.50$ to 0.78$)$

Daily activities:

Treatment: 0.68

Control: 0.91

$-0.23(-0.71$ to 0.26$)$

Social activities:

Treatment: 0.98

Control: 0.91

$0.07(-0.61$ to 0.74$)$

Pain:

Treatment: 1.02

Control: 1.06

$-0.04(-0.62$ to 0.53$)$

Change in health:

Treatment: 0.48

Control: 0.62

$-0.14(-0.73$ to 0.45$)$

Overall health:

Treatment: -0.11

Control: 0.15

$-0.26(-0.65$ to 0.12$)$

Social support:

Treatment: 0.18

Control: -0.03 
Early discharge of patients following surgery (Continued)

$[0.21,-0.33$ to 0.74$]$

Quality of life:

Treatment: 0.42

Control: 0.40

[0.02, -0.37 to 0.41$]$

Bristol knee score *:

Treatment: -3.00

Control: -4.06

[1.06, -1.58 to 3.70$]$

HYSTERECTOMY

Physical fitness

Treatment: 0.04

Control: 0.04

$[0.00,-0.43$ to 0.44$]$

Feelings:

Treatment: 0.70

Control: 0.84

$[-0.14,-0.48$ to 0.19$]$

Daily activities:

Treatment: 0.52

Control: 0.45

[0.07, -0.25 to 0.38 ]

Social activities:

Treatment: 0.56

Control: 0.52

$[0.04,-0.30$ to 0.38$]$

Pain:

Treatment: 1.22

Control: 1.20

$[0.02,-0.42$ to 0.48$]$

Change in health:

Treatment: 1.45

Control: 1.36

$[0.09,-0.22$ to 0.40$]$

Overall health:

Treatment: 1.09

Control: 0.82

$[0.27,-0.06$ to 0.58$]$ 


\section{Early discharge of patients following surgery (Continued)}

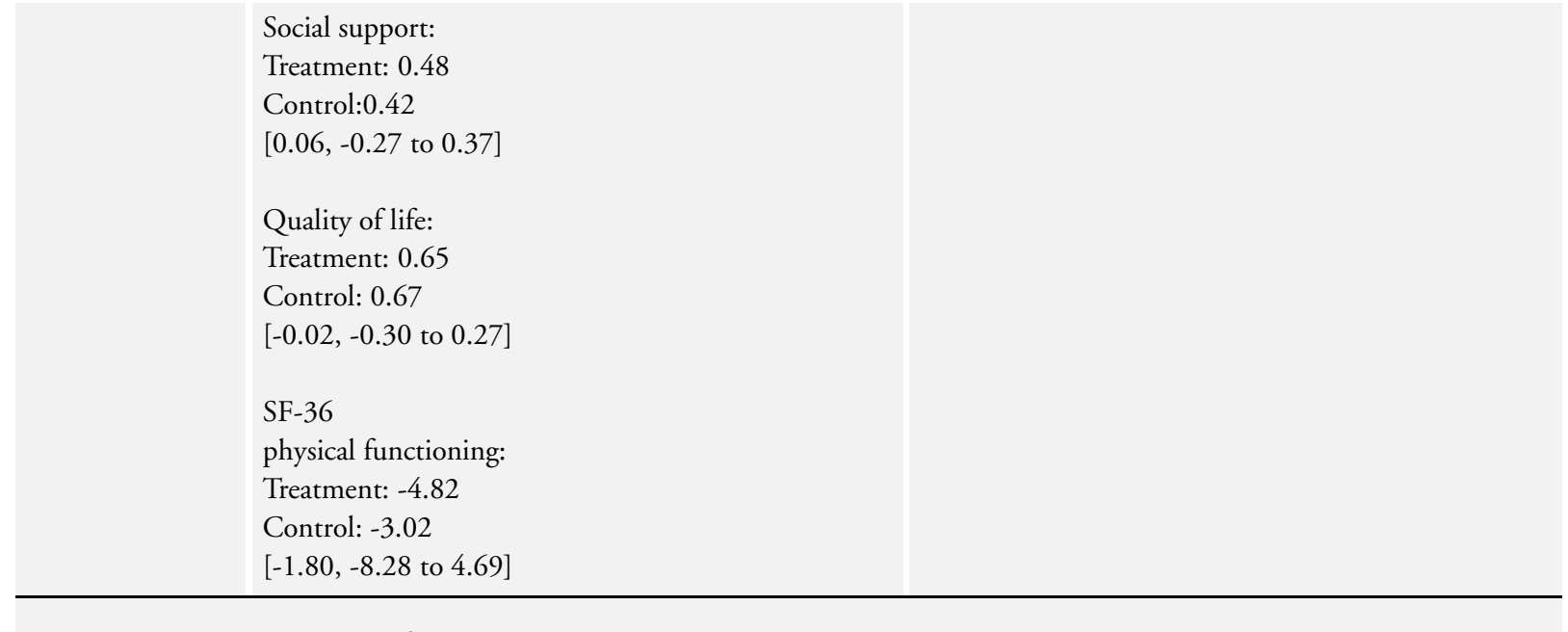

\section{Patient outcomes: patient satisfaction}

\begin{tabular}{|c|c|c|}
\hline Adler 1978 & $\begin{array}{l}\text { Patient satisfaction: } \\
\text { At } 14 \text { days: } \\
\text { treatment: } 76 / 117(64.9 \%) \\
\text { control: } 62 / 107(57.9 \%) \\
\text { observed difference: } 7 \% \\
95 \% \text { CI }-6 \% \text { to } 20 \%\end{array}$ & $\begin{array}{l}\text { Patients were asked if they were content with their } \\
\text { length of stay in hospital }\end{array}$ \\
\hline Crotty 2002 & $\begin{array}{l}\text { Patient satisfaction: median score }(25 \text { th } \& 75 \text { th per- } \\
\text { centile) } \\
\text { treatment: } 21.0(19.0 \text { to } 23.0) \\
\text { control: } 20.0(18.0 \text { to } 22.0)\end{array}$ & $\begin{array}{l}\text { Only } 20 \% \text { of those with a fracture were eligible and } \\
\text { agreed to enter trial }\end{array}$ \\
\hline Richards 1998 & $\begin{array}{l}\text { Quality of service (excellent): } \\
\text { Treatment: } 50.7 \% \\
\text { Control: } 44.6 \% \\
\text { [6.1\%, }-8.6 \% \text { to } 20.8 \%] \\
\text { Received needed services (all of the time): } \\
\text { Treatment: } 63 \% \\
\text { Control: } 60 \% \\
\text { [3.0\%, }-11.5 \% \text { to } 17.4 \%] \\
\text { Content with care (all of the time): } \\
\text { Treatment: } 69.6 \\
\text { Control: } 56.9 \\
\text { [12.7,-1.6 to } 27.0] \\
\text { Received all help needed (yes): } \\
\text { Treatment: } 83.8 \\
\text { Control:75.4 } \\
\text { [8.4, }-3.7 \text { to } 20.6]\end{array}$ & Patient satisfaction measured at 4 weeks follow-up \\
\hline
\end{tabular}




\section{Early discharge of patients following surgery (Continued)}

Discussions with staff (excellent):

Treatment: 47.4

Control: 27.7

$[19.7,5.9$ to 33.5$]$

Involved in decision making (as much as wanted):

Treatment: 79.4

Control: 71.5

[7.7, -5.7 to 21.1$]$

Information about illness (as much as wanted):

Treatment: 76.7

Control: 80.0

$[-3.3,-15.7$ to 9.2$]$

Information on treatment (as much as wanted):

Treatment: 77.5

Control:80.7

$[-3.2,-11.2$ to 17.8$]$

Privacy (as much as wanted):

Treatment: 84.7

Control: 88.1

$[-3.4,-13.7$ to 6.9$]$

Informal practical support (as much as wanted):

Treatment: 87

Control: 93.2

$[-6.2,-14.8$ to 2.4$]$

Informal emotional support (as much as wanted):

Treatment: 93.9

Control: 96.6

$[-2.7,-8.9$ to 3.5$]$

Ruckley 1978 Patient satisfaction:

Advantages seen by patients: treatment: 108/117 (92.

3\%) control: 95/121 (78.5\%)

difference: $13.8 \%$

$95 \%$ CI $5 \%$ to $23 \%$

Disadvantages seen by patients for carers:

treatment $=39 / 117(33.3 \%)$ control $=14 / 121(11.6 \%)$

Difference: $21.8 \%$

$95 \%$ CI $11.5 \%$ to $32 \%$

At discharge from hospital at home, or hospital:

Treatment=25.0 (3.11) 
Early discharge of patients following surgery (Continued)

\begin{tabular}{|c|c|c|}
\hline & $\begin{array}{l}\text { Control }=24.66(3.05) \\
{[0.83,-5.23 \text { to } 6.89]} \\
\text { At discharge from hospital at home, or hospital: } \\
\text { Treatment }=25.0(3.11) \\
\text { Control }=24.66(3.05) \\
{[0.83,-5.23 \text { to } 6.89]}\end{array}$ & \\
\hline Shepperd 1998 & 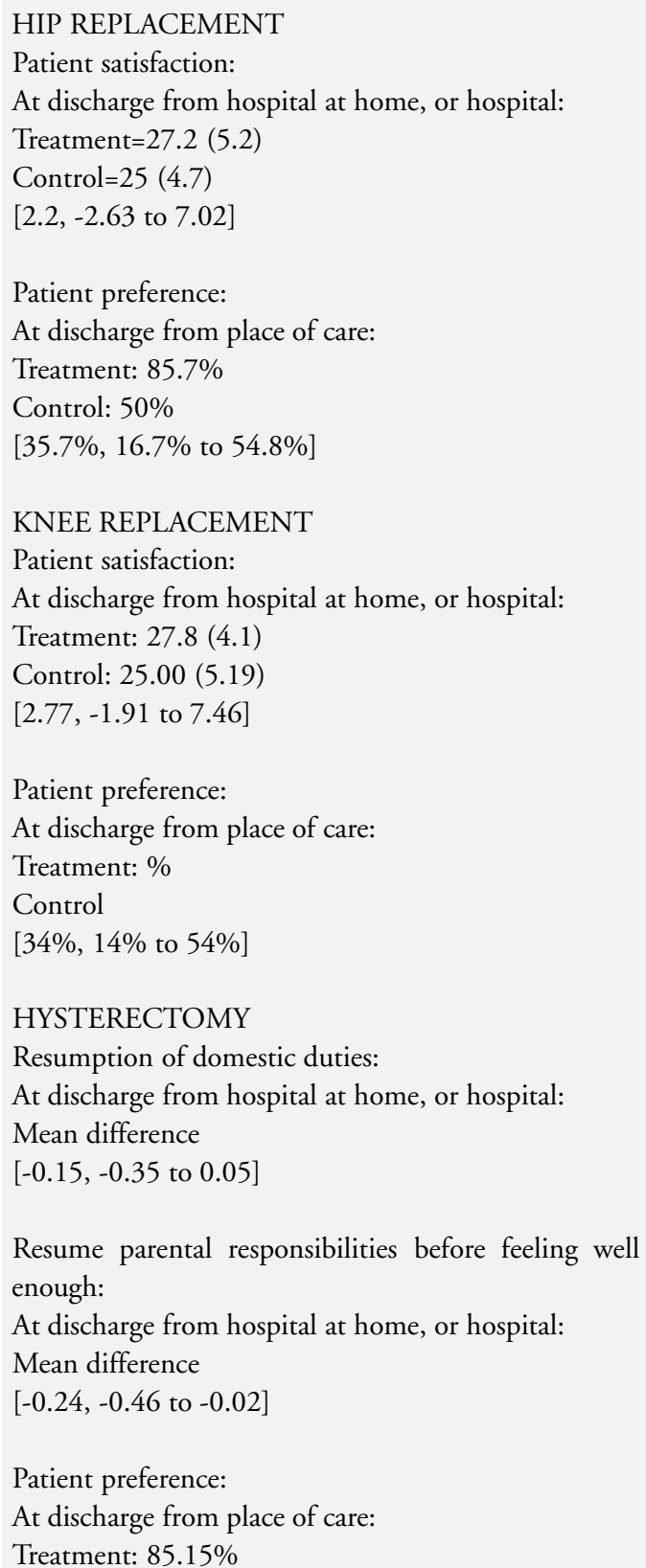 & $\begin{array}{l}\text { Patient satisfaction - using modified version of satisfac- } \\
\text { tion scale developed by Pound, maximum score of } 33 \text {, } \\
\text { indication high level of satisfaction } \\
\text { Resumption of domestic duties and parental responsi- } \\
\text { bilities - p;atients were asked to agree or disagree with } \\
\text { statement on a } 0 \text { - } 3 \text { scale ( } 3 \text { indicating high level of } \\
\text { agreement) } \\
\text { Patient preference - patients reporting they had received } \\
\text { their preferred place of care }\end{array}$ \\
\hline
\end{tabular}


Early discharge of patients following surgery (Continued)

Control: $66.7 \%$

[19\%, $8 \%$ to $30 \%]$

Carer outcomes

\begin{tabular}{|c|c|c|}
\hline Crotty 2002 & $\begin{array}{l}\text { Median change from baseline and } 25 \text { th } \& 75 \text { th per- } \\
\text { centile: } \\
\text { SF36 Physical component scale: } \\
\text { treatment: }-0.9(-7.1,5.3) \text { control: } 5.2(-16.4,6.0) \\
\text { SF } 36 \text { Mental component scale: } \\
\text { treatment: } 3.7(-2.5 .9 .9) \\
\text { control: }-4.7(-19.8,10.3) \\
\text { Caregiver Strain Index: treatment: } 1.0(0,4.0) \text { control: } \\
2.0 \text { (0, } 6.8) \\
\text { Carer time spent: } \\
\text { treatment: } 18.6 \%(6.3 \text { to } 30.9) \\
\text { control: } 22.1 \%(9.6 \text { to } 34.7)\end{array}$ & $\begin{array}{l}4 \text { month follow up } \\
\text { SF } 36 \text { higher score indicates greater improvement, } \\
\text { Carer Strain Index a lower score indicates improvement }\end{array}$ \\
\hline Shepperd 1998 & $\begin{array}{l}\text { HIP REPLACEMENT } \\
\text { Carer Strain Index: } \\
\text { Treatment median: } 0.00 \\
\text { Control median: } 1.00 \\
\text { Mann Whitney p = } 0.34 \\
\text { Carer satisfaction: } \\
\text { Treatment: } 18.2 \text { (2.5) } \\
\text { Control: } 18.8 \text { (2.5) } \\
\text { [-0.68, -4.09 to 2.75] } \\
\text { Carer preference: } \\
\text { At } 3 \text { months: } \\
\text { Difference: } 18.9 \% \text {, } \\
\text { (-1.36\% to } 39.2 \%) \\
\text { KNEE REPLACEMENT } \\
\text { Carer Strain Index: } \\
\text { Treatment: } 0.25 \\
\text { Control:-0.58 } \\
\text { [0.83, 95\% CI -0.79 to 2.45] } \\
\text { Carer satisfaction: } \\
\text { Treatment: } 19.57 \text { (3.46) } \\
\text { Control: } 18.2 \text { (3.9) } \\
\text { [1.37, -2.55 to 5.29] } \\
\text { Carer preference: }\end{array}$ & $\begin{array}{l}\text { HIP REPLACEMENT Carer Strain Index - median } \\
\text { change from baseline at } 3 \text { months } \\
\text { Carer satisfaction - using modified version of satisfac- } \\
\text { tion scale developed by Pound, scale 0-24, high score } \\
\text { indicating high level of satisfaction } \\
\text { Carer preference - carers reporting they had received } \\
\text { their preferred place of care } \\
\text { KNEE REPLACEMENT and HYSTERECTOMY } \\
\text { Carer Strain Index - mean change from baseline at } 3 \\
\text { months } \\
\text { Carer satisfaction - modified version of scale developed } \\
\text { by Pound, scale } 0-24 \text {, high score indicating high level } \\
\text { of satisfaction } \\
\text { Carer preference - carers reporting they had received } \\
\text { their preferred place of care (KNEE REPLACEMENT) }\end{array}$ \\
\hline
\end{tabular}




\section{Early discharge of patients following surgery (Continued)}

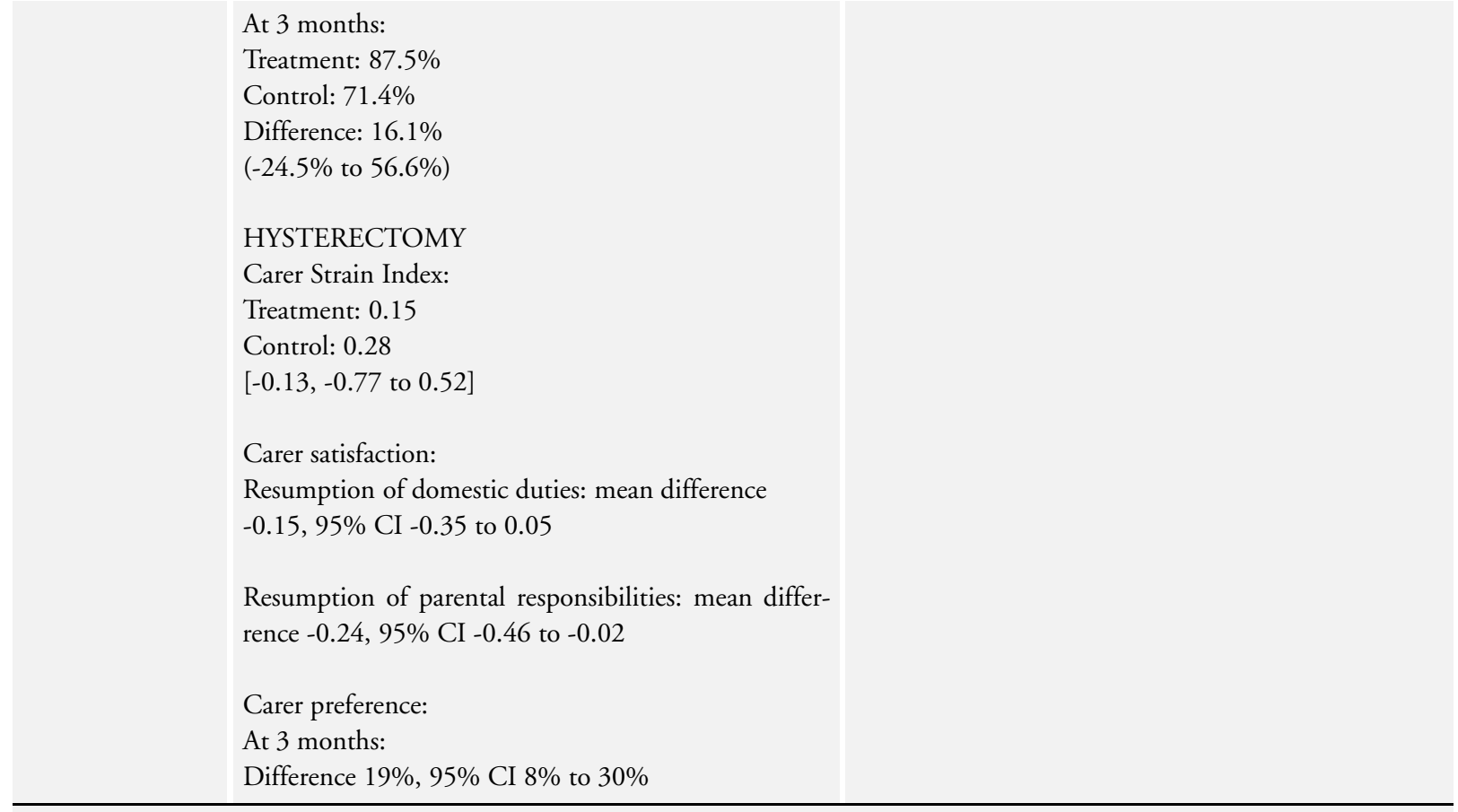

GP workload

\begin{tabular}{|c|c|c|}
\hline Adler 1978 & Verbal report & No $\mathrm{p}$ value given, insufficient data to calculate $\mathrm{CI}$ \\
\hline Crotty 2002 & $\begin{array}{l}\text { Visits to GP } \\
\text { treatment: } 3.3 \text { ( } 2.4 \text { to } 30.9) \\
\text { control: } 4.5(3.3 \text { to } 5.8) \\
\text { Use of community services: treatment: } 19 / 34(63 \%) \\
\text { control: } 23 / 32(77 \%)\end{array}$ & At 4 month follow up \\
\hline Ruckley 1978 & $\begin{array}{l}\text { At } 3 \text { weeks post-op: } \\
8 \text { minutes extra for day care patients }\end{array}$ & No $\mathrm{p}$ value given, insufficient data to calculate $\mathrm{CI}$ \\
\hline Shepperd 1998 & $\begin{array}{l}\text { Patients recovering from a hip replacement: } \\
\text { Home and surgery visits: } \\
\text { median difference: } £ 27.35 \mathrm{p}<0.06 \\
\text { Patients recovering from a knee replacement: } \\
\text { Home and surgery visits: } \\
\text { median difference: } £ 0.00 \\
\text { Patients recovering from a hysterectomy: } \\
\text { Home and surgery visits: } \\
\text { median difference: } £ 0.00\end{array}$ & Mann Whitney test \\
\hline
\end{tabular}


Early discharge of patients following surgery (Continued)

\section{Readmission to hospital}

\begin{tabular}{|c|c|c|}
\hline Crotty 2002 & $\begin{array}{l}\text { Mean readmission rate at } 4 \text { months: } \\
\text { treatment: } 0.22(0.07 \text { to } 0.46) \\
\text { control: } 0.22(0.01 \text { to } 0.45)\end{array}$ & \\
\hline Palmer Hill 2000 & $\begin{array}{l}\text { Readmission } \\
\text { treatment } 1 / 32 \text {; control } 1 / 28 \\
\text { Re admission days: } \\
\text { treatment } 0.22(0.01 \text { to } .045) \\
\text { control: } 0.27 \text { ( } 0.07 \text { to } 0.46)\end{array}$ & $\begin{array}{l}\text { Follow up time not specified, } 4 \text { months follow up for } \\
\text { re admission days }\end{array}$ \\
\hline Richards 1998 & $\begin{array}{l}\text { Treatment: } 5.6(13.84) \\
\text { Control: } 4.8(12.17) \\
\text { Difference } 0.8(-2.78 \text { to } 4.38) \\
\text { Treatment: } 42 / 159(26.4 \%) \\
\text { Control: } 17 / 81(21 \%) \\
\text { Difference } 5.4 \%(-5.8 \% \text { to } 16.6 \%)\end{array}$ & $\begin{array}{l}\text { Re admission days at } 3 \text { months (mix of surgical and } \\
\text { medical patients) }\end{array}$ \\
\hline Ruckley 1978 & $\begin{array}{l}\text { At } 2 \text { to } 3 \text { weeks: } \\
\text { treatment: } 0 / 117(0 \%) \\
\text { control: } 2 / 121(1.65 \%) \\
\text { observed difference } 1.65 \% \\
95 \% \text { CI }-3.92 \% \text { to } 0.62 \%\end{array}$ & \\
\hline Shepperd 1998 & $\begin{array}{l}\text { KNEE REPLACEMENT } \\
\text { At } 3 \text { months follow-up: } \\
\text { Treatment: } 4 / 47 \text { (8.5\%) } \\
\text { Control: } 1 / 39(2.6 \%) \\
\text { Difference } 5.9 \text { (-3.5 to } 15.3 \%) \\
\text { HIP REPLACEMENT } \\
\text { At } 3 \text { months follow-up: } \\
\text { Treatment: } 2 / 37 \text { (5.4\%) } \\
\text { Control: } 1 / 49 \text { (2.0\%) } \\
\text { Difference } 3.4 \%(-4.9 \% \text { to } 11.7 \%) \\
\text { HYSTERECTOMY } \\
\text { At } 3 \text { months follow-up } \\
\text { Treatment: } 7 / 114(6.1 \%) \\
\text { Control: } 13 / 124(10.5 \%) \\
\text { Difference }-4.3 \%(-11.3 \% \text { to } 2.6 \%)\end{array}$ & \\
\hline
\end{tabular}

\section{Cost}


Early discharge of patients following surgery (Continued)

\begin{tabular}{|c|c|c|}
\hline Adler 1978 & $\begin{array}{l}1971 / 72 \text { prices } \\
\text { Social cost (health service, society, patient) } \\
\text { difference: } £ 6.90 \text { per male hernia patient, } \\
\text { difference: } £ 19.62 \text { per female varicose vein patient }\end{array}$ & No $\mathrm{p}$ value given, insufficient data to calculate CI \\
\hline Booth 2004 & $\begin{array}{l}\text { Hospital costs for surgery } \\
T=£ 5644 \\
C=£ 5629 \\
\text { difference } £ 15,95 \% \text { CI }-363 \text { to } 457 \\
\text { Costs of readmission } T=£ 185 \\
C=£ 492 \\
\text { Difference } £-306.00 \\
95 \% \text { CI } £-758 \text { to } £ 61 \\
\text { Primary care costs } T=£ 58 \\
C=£ 63 \\
\text { Difference } £-5,95 \% \text { CI }-£ 32 \text { to } 18 \\
\text { Cost of hospital visits (includes pre admission clinic, } \\
\text { inpatient care, and home costs) } \\
T=£ 240 \\
C=£ 198 \\
\text { Difference } £ 42,95 \% \text { CI - } £ 45 \text { to } 124 \\
\text { Total costs at } 12 \text { weeks (include inpatient hospital care, } \\
\text { home care, primary care, readmission and home visit } \\
\text { costs. } T=£ 6127 \\
C=£ 6381 \\
\text { Difference } £-25495 \% \text { CI - } £ 919 \text { to } 348\end{array}$ & $\begin{array}{l}\text { Health service perspective. Costs estimated for each pa- } \\
\text { tient, unit costs obtained from the hospital financial } \\
\text { figures and published data }\end{array}$ \\
\hline Richards 1998 & $\begin{array}{l}\text { Total cost: } \\
\text { Treatment: } £ 2,516 \\
\text { Control: } £ 3,292 \\
\text { Difference } £ 750\end{array}$ & $\begin{array}{l}\text { No estimates of variance, no test of statistical signifi- } \\
\text { cance, confidence intervals can not be calculated } \\
\text { Cost data financial year } 1996 \text { for community services }\end{array}$ \\
\hline Ruckley 1978 & $\begin{array}{l}1975 / 76 \text { prices } \\
\text { Health service costs (for a } 48 \text { hour admission): treat- } \\
\text { ment }=£ 16 \text { per patient } \\
\text { control: } £ 46 \text { per patient }\end{array}$ & No $\mathrm{p}$ value given, insufficient data to calculate CI \\
\hline Shepperd 1998 & $\begin{array}{l}\text { HIP REPLACEMENT } \\
\text { Mean hospital costs: } \\
\text { Treatment: } £ 515.42(473.20) \\
\text { Control: } £ 776.30(364.53) \\
\text { Difference: }-260.88,95 \% \text { CI }-441.56 \text { to }-80.19 \mathrm{p}<0.01 \\
\text { Mean hospital at home costs } \\
\text { Treatment: } £ 351.24 \text { (240.58) } \\
\text { Mean total health service costs: } \\
\text { Treatment: } £ 911.39 \text { (563.76) } \\
\text { Control: } £ 815.70 \text { (347.99) }\end{array}$ & $\begin{array}{l}\text { Cost data financial year } 1994 / 1995 \text {. Health service per- } \\
\text { spective, dependency scores developed to account for } \\
\text { the different resouces used during a patient's inpatient } \\
\text { admission. Costs calculated at the patient level }\end{array}$ \\
\hline
\end{tabular}


Early discharge of patients following surgery (Continued)

Difference: $£ 95.69$ ratio of geometric mean 1.05, 95\%

CI 0.87 to $1.27, \mathrm{p}>0.50$

KNEE REPLACEMENT

Mean hospital costs:

Treatment: $£ 1092.24$ (615.27)

Control: $£ 1348.35$ (625.94)

Difference: $-256.11,95 \%$ CI -524.61 to 12.38 p $>0.06$

Mean hospital at home costs

Treatment: £348.16 (275.25)

Mean total health service costs:

Treatment: $£ 1461.62$ (666.61)

Control: $£ 1375.36$ (637.76)

Difference: $£ 86.26$ ratio of geometric mean $1.05,95 \%$

CI 0.88 to $1.26 \mathrm{p}>0.55$

\section{HYSTERECTOMY}

Mean hospital costs:

Treatment: $£ 487.43(350.20)$

Control: £647.77 (496.27)

Difference: -160.34 , ratio of geometric mean 0.76 , 95\%CI 0.67 to $0.87 \mathrm{p}<0.01$

Mean hospital at home costs

Treatment: $£ 250.18$ (273.54)

Mean total health service costs:

Treatment: $£ 771.78$ (408.72)

Control: $£ 679.39$ (439.83)

Difference: $£ 92.39$ ratio of geometric mean $1.15,95 \%$

CI 1.04 to $1.29 \mathrm{p}<0.01$

\section{Length of stay}

\begin{tabular}{l|ll}
\hline Booth 2004 & $\begin{array}{l}\text { Total hospital length of stay Mean (sd) } \\
\mathrm{T}=5.3(2.68)\end{array}$ & \\
& $\begin{array}{l}\mathrm{C}=8.0(1.78) \\
\mathrm{P}<0.001\end{array}$ & SD calculated from published CI \\
\hline Crotty 2002 & $\begin{array}{l}\text { Hospital length of stay, mean }(95 \% \mathrm{CI}) \\
\text { treatment } 7.8 \text { days sd } 9.6(4.5 \text { to } 11.0) \\
\text { control: } 14.3 \text { days sd } 10.8(10.5 \text { to } 18.1) \\
\text { difference } 6.5 \text { days } \mathrm{p}<0.05\end{array}$ & \\
& $\begin{array}{l}\text { Total days of care: treatment: } 28.3 \text { days }(23.1 \text { to 33.6) } \\
\text { control: } 14.3 \text { days }(10.5 \text { to } 18.1)\end{array}$ & \\
\hline Richards 1998 & $\begin{array}{l}\text { Hospital length of stay for patients with a surgical con- } \\
\text { dition: } \\
\text { Treatment }(\mathrm{n}=104) \text { mean:18.48 (17.1) } \\
\text { Control (n=54) mean: } 26.59(24.61)\end{array}$ & $\begin{array}{l}\text { Length of stay for patients with a surgical condition - } \\
\text { data obtained from authors }\end{array}$ \\
\hline
\end{tabular}


Early discharge of patients following surgery (Continued)

\begin{tabular}{|c|c|c|}
\hline & 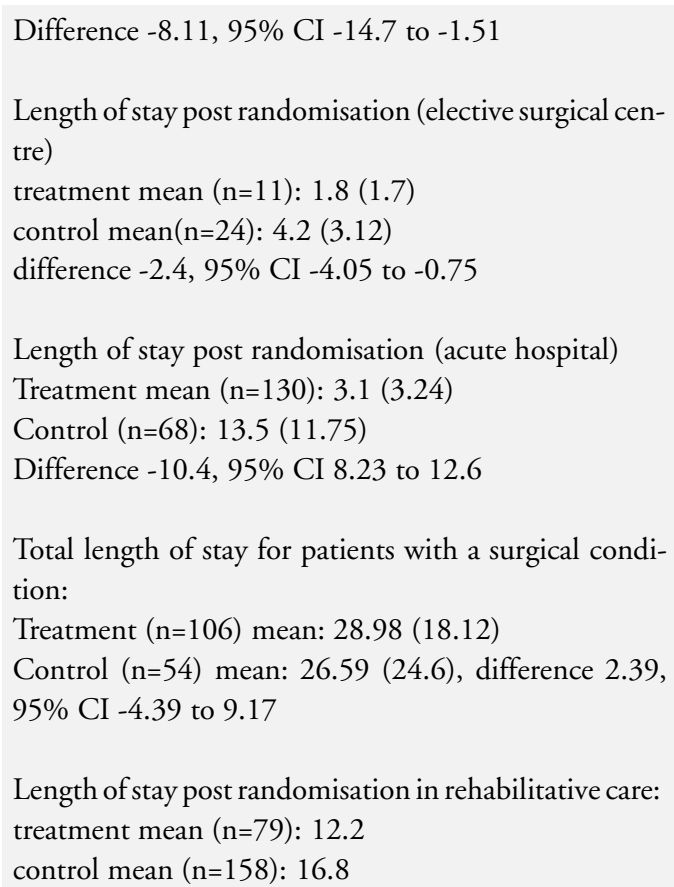 & tre, acute hospital, in rehabilitative care - published data \\
\hline Shepperd 1998 & $\begin{array}{l}\text { HOSPITAL LENGTH OF STAY } \\
\text { Patients recovering from a hip replacement: } \\
\text { Treatment: } 8.11 \text { (5.52) } \\
\text { Control: } 11.87 \text { (4.52) } \\
\text { Difference }-3.7595 \% \text { CI }-5.92 \text { to }-1.58 \\
\text { Patients recovering from a knee replacement: } \\
\text { Treatment: } 10.28 \text { (4.6) } \\
\text { Control: } 13.31 \text { (4.57) } \\
\text { Difference }-3.0295 \% \text { CI-5.01 to }-1.04) \\
\text { Patients recovering from a hysterectomy: } \\
\text { Treatment: } 4.34 \text { (1.86) } \\
\text { Control: } 5.79 \text { (2.98) } \\
\text { Difference }-1.4495 \% \text { CI- } 2.09 \text { to }-0.79 \\
\text { TOTAL DAYS OF CARE } \\
\text { Patients recovering from a hip replacement: } \\
\text { Treatment: } 14.69 \text { (5.13) } \\
\text { Control: } 11.87 \text { (4.52) } \\
\text { Difference }-2.8495 \% \text { CI } 0.75 \text { to } 4.93 \\
\text { Patients recovering from a knee replacement: } \\
\text { Treatment: } 16 \text { (5.44) } \\
\text { Control: } 13.31 \text { ( } 4.57 \text { ) } \\
\text { Difference } 2.6995 \% \text { CI } 0.5 \text { to } 4.88\end{array}$ & $\begin{array}{l}\text { Hospital length of stay - mean (sd) unless stated other- } \\
\text { wise } \\
\text { Total days of care - mean (sd) unless stated otherwise }\end{array}$ \\
\hline
\end{tabular}


Early discharge of patients following surgery (Continued)

Patients recovering from a hysterectomy:

Treatment: 7.45 (2.59)

Control: 5.79 (2.98)

Difference 1.66 95\% CI 0.94 to 2.39

\section{Carer satisfaction}

Adler 1978 Difference between groups reported as significant with No p value given, insufficient data to calculate CI carer in the treatment group less satisfied

\begin{tabular}{|c|c|}
\hline Ruckley 1978 & $\begin{array}{l}\text { At } 1 \text { week: } \\
\text { Advantages seen by carers for others: } \\
\text { treatment: } 31 / 117(26.5 \%) \text { control: } 12 / 121(9.9 \%) \text { ob- } \\
\text { served difference: } 16.6 \% \\
\text { p < } 0.00195 \% \text { CI } 6.9 \% \text { to } 26 \% \\
\text { Advantages seen by carers for patients: } \\
\text { treatment: } 97 / 117 \text { ( } 83 \%) \\
\text { control: } 98 / 121(81 \%) \\
\text { observed difference } 1.9 \% \\
95 \% \text { CI }-7.8 \% \text { to } 11.7 \% \\
\text { Advantages seen by carers for themselves: } \\
\text { treatment: } 79 / 117(67.5 \%) \\
\text { control: } 86 / 121 \text { ( } 71.1 \%) \\
\text { observed difference }-3.6 \% \\
95 \% \text { CI }-15.3 \% \text { to } 8.2 \% \\
\text { Disadvantages seen by carers for patients: } \\
\text { treatment: } 26 / 117(22.2 \%) \text { control: } 14 / 121(11.6 \%) \\
\text { observed difference: } 10.6 \% \\
\text { p < } 0.0595 \% \text { CI } 1.2 \% \text { to } 20 \% \\
\text { Disadvantages seen by carers of themselves: } \\
\text { treatment: } 38 / 117(32.5 \%) \text { control: } 12 / 121(9.9 \%) \text { ob- } \\
\text { served difference: } 22.6 \% \\
\text { p < } 0.001 \\
95 \% \text { CI } 12 \% \text { to } 33 \% \\
\text { Disadvantages seen by carers for others: } \\
\text { treatment: } 5 / 117 \text { ( } 4.3 \%) \\
\text { control: } 6 / 121 \text { ( } 4.9 \%) \\
\text { observed difference }-0.7 \% \\
95 \% \text { CI - } 6 \% \text { to } 4.6 \%\end{array}$ \\
\hline
\end{tabular}


Analysis I.2I. Comparison I Hospital at home versus in-patient care, Outcome 2 I Hospital length of stay older people recovering from surgery.

Review: Hospital at home early discharge

Comparison: I Hospital at home versus in-patient care

Outcome: 21 Hospital length of stay - older people recovering from surgery

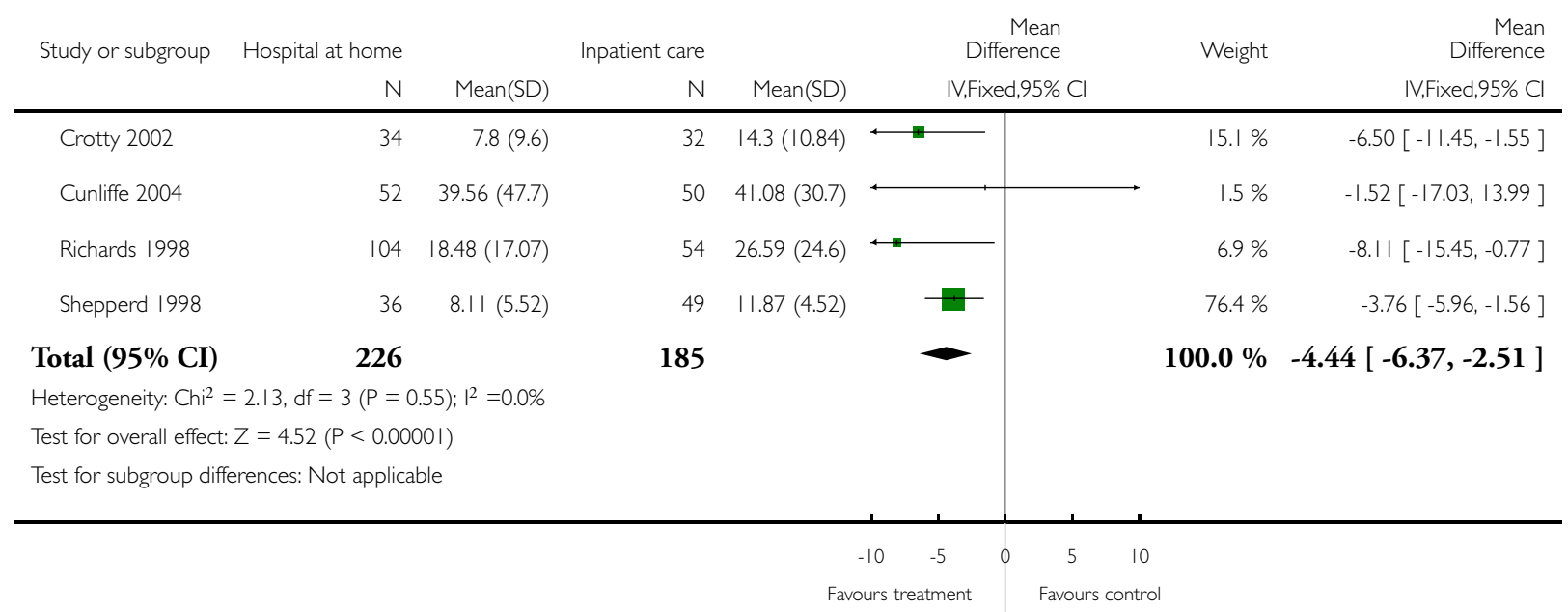

Analysis I.22. Comparison I Hospital at home versus in-patient care, Outcome 22 Total length of stay older people having elective surgery.

Review: Hospital at home early discharge

Comparison: I Hospital at home versus in-patient care

Outcome: 22 Total length of stay - older people having elective surgery

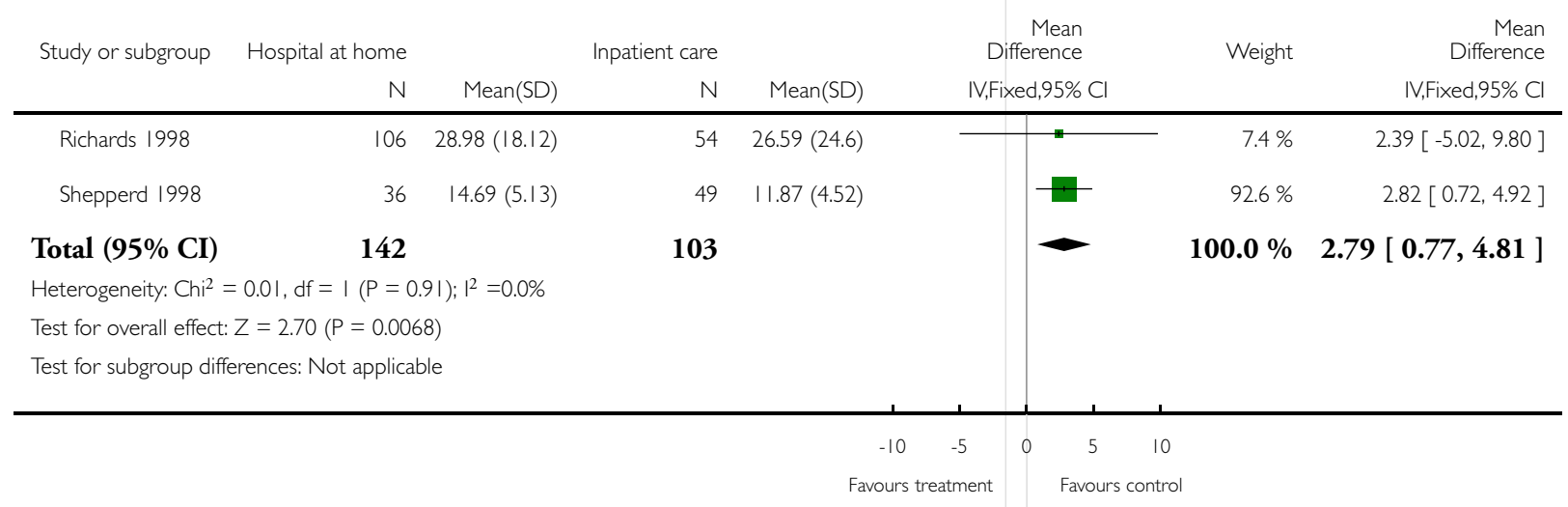


Analysis I.23. Comparison I Hospital at home versus in-patient care, Outcome 23 Readmission to hospital - surgery.

Review: Hospital at home early discharge

Comparison: I Hospital at home versus in-patient care

Outcome: 23 Readmission to hospital - surgery

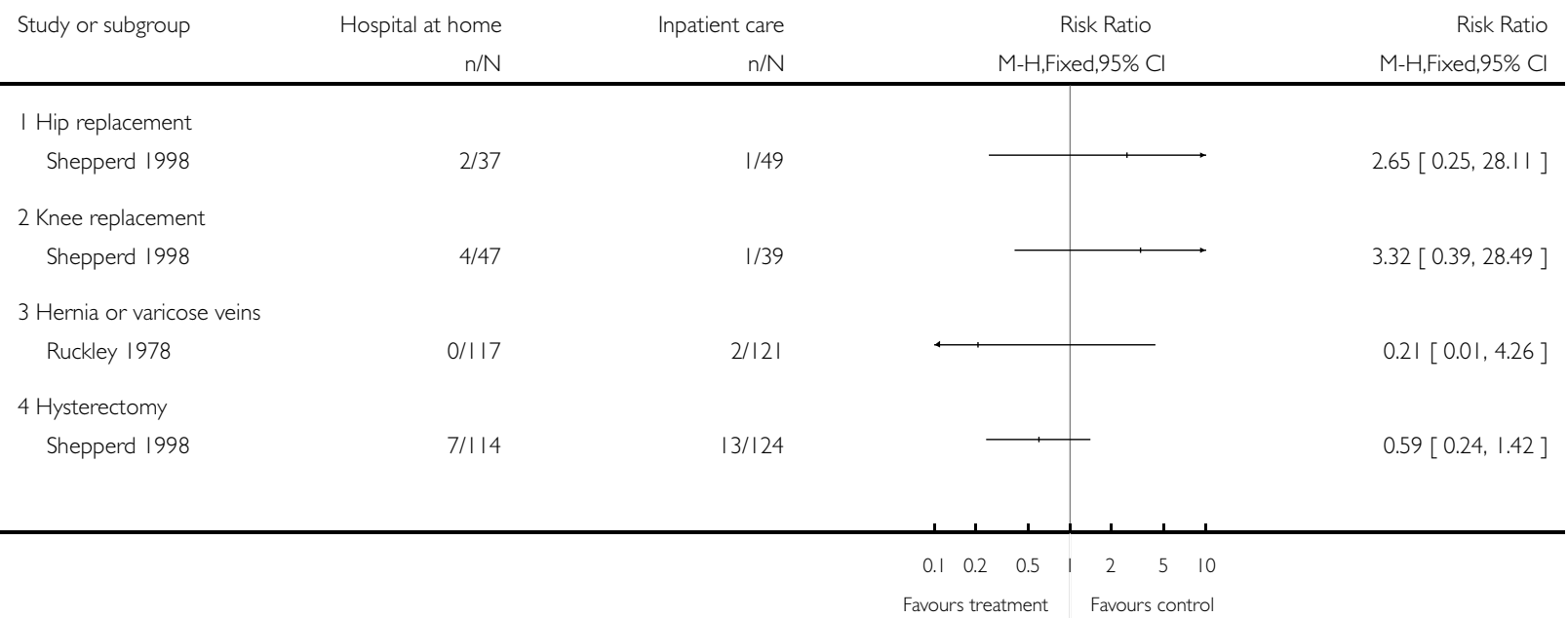


Analysis 2.I. Comparison 2 IPD data analysis, Outcome I IPD generic inverse variance early discharge elderly medical mortality at 3 months.

Review: Hospital at home early discharge

Comparison: 2 IPD data analysis

Outcome: I IPD generic inverse variance early discharge elderly medical mortality at 3 months

\begin{tabular}{|c|c|c|c|c|c|c|}
\hline \multirow[t]{2}{*}{ Study or subgroup } & Hospital at home & Inpatient care & $\log [$ Mortality] & Mortality & \multirow[t]{2}{*}{ Weight } & \multirow{2}{*}{$\begin{array}{r}\text { Mortality } \\
\text { IV,Fixed,95\% C }\end{array}$} \\
\hline & $\mathrm{N}$ & $\mathrm{N}$ & (SE) & IV,Fixed,95\% Cl & & \\
\hline \multicolumn{7}{|c|}{ I Mortality at 3 months in older patients with a mix of conditions (Martin at 6 months) } \\
\hline Cunliffe 2004 & 185 & 185 & $-0.13(0.344)$ & + & $38.7 \%$ & $0.88[0.45,1.72]$ \\
\hline Harris 2005 & 104 & 105 & $0.229(0.475)$ & $F$ & $20.3 \%$ & $1.26[0.50,3.19]$ \\
\hline Martin 1994 & 29 & 25 & $-0.21(0.817)$ & $\longrightarrow$ & $6.9 \%$ & $0.81[0.16,4.02]$ \\
\hline Richards 1998 & 143 & 76 & $-0.318(0.527)$ & $\rightarrow$ & $16.5 \%$ & $0.73[0.26,2.04]$ \\
\hline Shepperd 1998 & 63 & 63 & $0.617(0.508)$ & $\mp$ & $17.7 \%$ & $1.85[0.68,5.02]$ \\
\hline Total (95\% CI) & & & & $\rightarrow$ & $100.0 \%$ & $1.04[0.68,1.58]$ \\
\hline \multicolumn{7}{|c|}{ Heterogeneity: $\mathrm{Chi}^{2}=2.25, \mathrm{df}=4(P=0.69) ; \mathrm{I}^{2}=0.0 \%$} \\
\hline \multicolumn{7}{|c|}{ Test for overall effect: $Z=0.18(P=0.86)$} \\
\hline Test for subgroup diff & ences: Not applicable & & & & & \\
\hline
\end{tabular}

Analysis 2.2. Comparison 2 IPD data analysis, Outcome 2 IPD generic inverse variance early discharge readmission at 3 months.

Review: Hospital at home early discharge

Comparison: 2 IPD data analysis

Outcome: 2 IPD generic inverse variance early discharge readmission at 3 months

\begin{tabular}{|c|c|c|c|c|c|c|}
\hline Study or subgroup & $\begin{array}{r}\text { Hospital at home } \\
\text { N }\end{array}$ & $\begin{array}{r}\text { Inpatient care } \\
\text { N }\end{array}$ & $\begin{array}{r}\log [\text { Readmission }] \\
(\mathrm{SE})\end{array}$ & $\begin{array}{l}\text { Readmission } \\
\text { IV,Fixed,95\% Cl }\end{array}$ & Weight & $\begin{array}{r}\text { Readmission } \\
\text { IV,Fixed,95\% Cl }\end{array}$ \\
\hline Cunliffe 2004 & 185 & 185 & $0.226(0.213)$ & 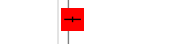 & $71.1 \%$ & $1.25[0.83,1.90]$ \\
\hline Harris 2005 & 104 & 105 & $0.996(0.677)$ & 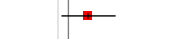 & $7.0 \%$ & $2.71[0.72,10.21]$ \\
\hline Shepperd 1998 & 63 & 63 & $0.867(0.384)$ & \# & $21.9 \%$ & $2.38[1.12,5.05]$ \\
\hline Total $(95 \% \mathrm{CI})$ & & & & $\bullet$ & $100.0 \%$ & $1.52[1.07,2.16]$ \\
\hline \multicolumn{7}{|c|}{ Heterogeneity: $\mathrm{Chi}^{2}=2.9 \mathrm{I}, \mathrm{df}=2(P=0.23) ; \mathrm{I}^{2}=31 \%$} \\
\hline \multicolumn{7}{|c|}{ Test for overall effect: $Z=2.34(P=0.019)$} \\
\hline Test for subgroup diff & ences: Not applicable & & & & & \\
\hline
\end{tabular}

$0.0010 .010 .1 \quad 1 \quad 10 \quad 100 \quad 1000$

Favours treatment Favours control 
Analysis 2.3. Comparison 2 IPD data analysis, Outcome 3 IPD stroke mortality at 3 to 6 months Manchester, Anderson, Cunliffe, Shepperd 3 months.

Review: Hospital at home early discharge

Comparison: 2 IPD data analysis

Outcome: 3 IPD stroke mortality at 3 to 6 months - Manchester, Anderson, Cunliffe, Shepperd 3 months

\begin{tabular}{|c|c|c|c|c|c|c|}
\hline Study or subgroup & $\begin{array}{l}\text { Hospital at home } \\
\text { N }\end{array}$ & $\begin{array}{l}\text { Inpatient care } \\
\text { N }\end{array}$ & $\begin{array}{r}\log [\text { Mortality }] \\
(\mathrm{SE})\end{array}$ & $\begin{array}{r}\text { Mortality } \\
\text { IV,Fixed,95\% Cl }\end{array}$ & Weight & $\begin{array}{r}\text { Mortality } \\
\text { IV,Fixed,95\% Cl }\end{array}$ \\
\hline Anderson 2000 & 42 & 44 & $2.0819(1.4276)$ & $\Psi$ & $10.0 \%$ & $8.02[0.49,131.62]$ \\
\hline Bautz-Holter 2002 & 42 & 40 & $-0.739(0.866)$ & $\longrightarrow$ & $27.2 \%$ & $0.48[0.09,2.61]$ \\
\hline Cunliffe 2004 & 43 & 44 & $1.158(1.155)$ & $\longrightarrow$ & $15.3 \%$ & $3.18[0.33,30.62]$ \\
\hline Donnelly 2004 & 59 & 53 & $-0.801(1.225)$ & $\longrightarrow$ & $13.6 \%$ & $0.45[0.04,4.95]$ \\
\hline Manchester FASTER & 12 & 11 & $-0.754(1.225)$ & $\longrightarrow$ & $13.6 \%$ & $0.47[0.04,5.19]$ \\
\hline Shepperd 1998 & 11 & 10 & $0.95(1.9949)$ & 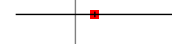 & $5.1 \%$ & $2.59[0.05,129.02]$ \\
\hline Widen-Holmqvist 1998 & 42 & 41 & $-1.161(1.155)$ & $\longrightarrow$ & $15.3 \%$ & $0.31[0.03,3.01]$ \\
\hline Total $(95 \%$ CI $)$ & & & & & $100.0 \%$ & $0.86[0.35,2.07]$ \\
\hline \multicolumn{7}{|c|}{ Heterogeneity: Chi $^{2}=5.78, d f=6(P=0.45) ;\left.\right|^{2}=0.0 \%$} \\
\hline \multicolumn{7}{|c|}{ Test for overall effect: $Z=0.34(P=0.73)$} \\
\hline Test for subgroup difference & Not applicable & & & & & \\
\hline
\end{tabular}

$0.0010 .01 \quad 0.1 \quad 1 \quad 10 \quad 100 \quad 1000$

Favours treatment Favours control

Analysis 2.4. Comparison 2 IPD data analysis, Outcome 4 Stroke Barthel at 3 months.

Review: Hospital at home early discharge

Comparison: 2 IPD data analysis

Outcome: 4 Stroke Barthel at 3 months

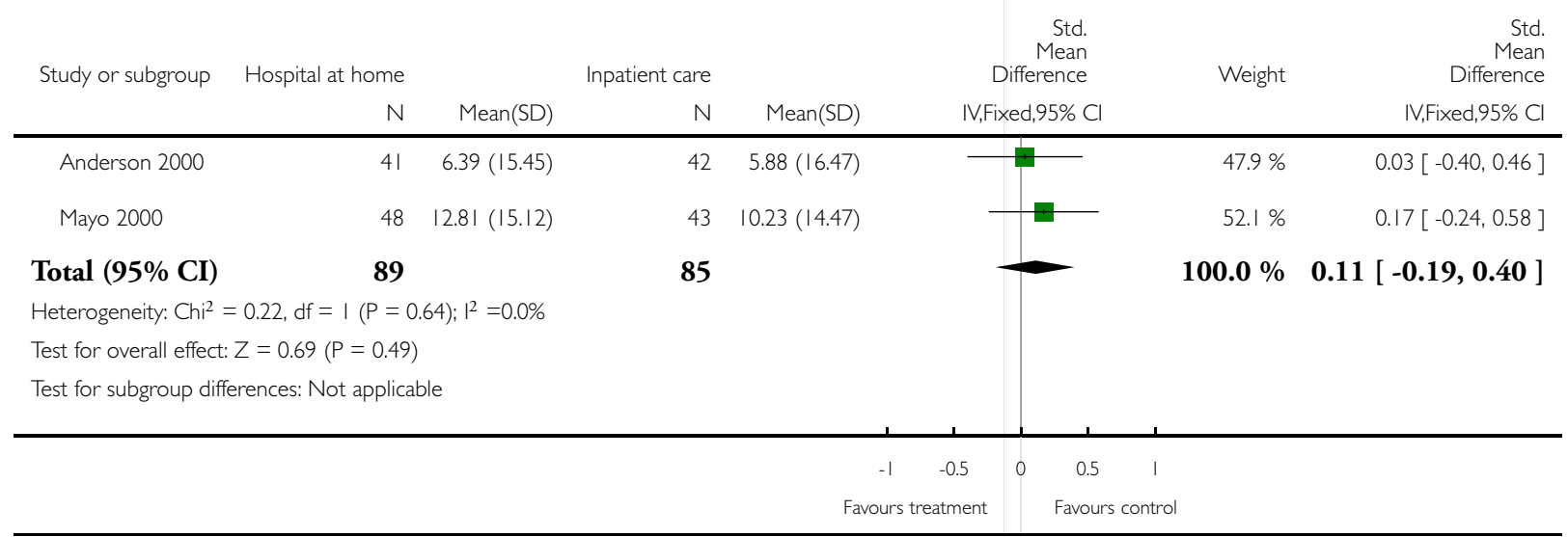




\section{Analysis 2.5. Comparison 2 IPD data analysis, Outcome 5 Stroke Barthel at 6 months.}

Review: Hospital at home early discharge

Comparison: 2 IPD data analysis

Outcome: 5 Stroke Barthel at 6 months

\begin{tabular}{|c|c|c|c|c|c|c|c|}
\hline \multirow[t]{2}{*}{ Study or subgroup } & \multirow{2}{*}{$\begin{array}{r}\text { Hospital at home } \\
\text { N }\end{array}$} & \multicolumn{3}{|c|}{ Inpatient care } & $\begin{array}{r}\text { Std. } \\
\text { Mean } \\
\text { Difference }\end{array}$ & \multirow[t]{2}{*}{ Weight } & \multirow{2}{*}{$\begin{array}{r}\text { Std. } \\
\text { Mean } \\
\text { Difference } \\
\mathrm{IV}, \text { Fixed,95\% Cl }\end{array}$} \\
\hline & & Mean(SD) & $\mathrm{N}$ & Mean(SD) & IV,Fixed,95\% Cl & & \\
\hline Anderson 2000 & 40 & $5.98(18.19)$ & 42 & $5.69(|8.0|)$ & + & $44.5 \%$ & $0.02[-0.42,0.45]$ \\
\hline Donnelly 2004 & 56 & $3.38(3.02)$ & 47 & $3.36(3.3)$ & + & $55.5 \%$ & $0.01[-0.38,0.39]$ \\
\hline Total $(95 \% \mathrm{CI})$ & 96 & & 89 & & $\rightarrow$ & $100.0 \%$ & $0.01[-0.28,0.30]$ \\
\hline \multicolumn{8}{|c|}{ Heterogeneity: $\mathrm{Chi}^{2}=0.00, \mathrm{df}=\mathrm{I}(\mathrm{P}=0.97) ; \mathrm{I}^{2}=0.0 \%$} \\
\hline \multicolumn{8}{|c|}{ Test for overall effect: $Z=0.07(P=0.94)$} \\
\hline \multicolumn{8}{|c|}{ Test for subgroup differences: Not applicable } \\
\hline & & & & & 0 & 4 & \\
\hline & & & & & Favour & trol & \\
\hline
\end{tabular}


Analysis 2.6. Comparison 2 IPD data analysis, Outcome 6 Sensitivity analysis in favour of HAH.

Review: Hospital at home early discharge

Comparison: 2 IPD data analysis

Outcome: 6 Sensitivity analysis in favour of $\mathrm{HAH}$

\begin{tabular}{|c|c|c|c|c|c|c|}
\hline \multirow[t]{2}{*}{ Study or subgroup } & Hospital at home & Inpatient care & $\log [$ Mortality] & Mortality & \multirow[t]{2}{*}{ Weight } & \multirow{2}{*}{$\begin{array}{r}\text { Mortality } \\
\text { IV,Fixed,95\% Cl }\end{array}$} \\
\hline & $\mathrm{N}$ & N & $(\mathrm{SE})$ & IV,Fixed,95\% Cl & & \\
\hline \multicolumn{7}{|c|}{ I Sensitivity analysis changing follow-up time of Richards trial in favour of $\mathrm{HAH}$} \\
\hline Cunliffe 2004 & 185 & 185 & $-0.13(0.344)$ & \# & $38.7 \%$ & $0.88[0.45,1.72]$ \\
\hline Harris 2005 & 104 & 105 & $0.229(0.475)$ & $T$ & $20.3 \%$ & $1.26[0.50,3.19]$ \\
\hline Martin 1994 & 29 & 25 & $-0.21(0.817)$ & $\longrightarrow$ & $6.9 \%$ & $0.81[0.16,4.02]$ \\
\hline Richards 1998 & 143 & 76 & $-0.396(0.527)$ & $\rightarrow$ & $16.5 \%$ & $0.67[0.24,1.89]$ \\
\hline Shepperd 1998 & 63 & 63 & $0.617(0.508)$ & - & $17.7 \%$ & $1.85[0.68,5.02]$ \\
\hline Total $(95 \% \mathrm{CI})$ & & & & $\rightarrow$ & $100.0 \%$ & $1.03[0.67,1.56]$ \\
\hline \multicolumn{7}{|c|}{ Heterogeneity: $\mathrm{Chi}^{2}=2.47, \mathrm{df}=4(\mathrm{P}=0.65) ; \mathrm{I}^{2}=0.0 \%$} \\
\hline \multicolumn{7}{|c|}{ Test for overall effect: $Z=0.12(P=0.90)$} \\
\hline Test for subgroup diffe & nces: Not applicable & & & & & \\
\hline
\end{tabular}

$0.0010 .01 \quad 0.1 \quad 1 \quad 10 \quad 1001000$

Favours treatment Favours control 
Analysis 2.7. Comparison 2 IPD data analysis, Outcome 7 Sensitivity analysis in favour of hospital.

Review: Hospital at home early discharge

Comparison: 2 IPD data analysis

Outcome: 7 Sensitivity analysis in favour of hospital

\begin{tabular}{|c|c|c|c|c|c|c|}
\hline \multirow[t]{2}{*}{ Study or subgroup } & Hospital at home & Inpatient care & $\log [$ Mortality] & \multirow{2}{*}{$\begin{array}{r}\text { Mortality } \\
\text { IV,Fixed,95\% Cl }\end{array}$} & \multirow[t]{2}{*}{ Weight } & \multirow{2}{*}{$\begin{array}{r}\text { Mortality } \\
\text { IV,Fixed,95\% Cl }\end{array}$} \\
\hline & $\mathrm{N}$ & N & $(\mathrm{SE})$ & & & \\
\hline \multicolumn{7}{|c|}{ I Sensitivity analysis changing follow-up time of Richards trial in favour of hospital } \\
\hline Cunliffe 2004 & 185 & 185 & $-0.13(0.344)$ & + & $38.7 \%$ & $0.88[0.45,1.72]$ \\
\hline Harris 2005 & 104 & 105 & $0.229(0.475)$ & & $20.3 \%$ & $1.26[0.50,3.19]$ \\
\hline Martin 1994 & 29 & 25 & $-0.21(0.817)$ & $\longrightarrow$ & $6.9 \%$ & $0.81[0.16,4.02]$ \\
\hline Richards 1998 & 143 & 76 & $-0.293(0.527)$ & $\rightarrow$ & $16.5 \%$ & $0.75[0.27,2.10]$ \\
\hline Shepperd 1998 & 63 & 63 & $0.617(0.508)$ & $\mp-$ & $17.7 \%$ & $1.85[0.68,5.02]$ \\
\hline Total (95\% CI) & & & & $\rightarrow$ & $100.0 \%$ & $1.04[0.69,1.59]$ \\
\hline \multicolumn{7}{|c|}{ Heterogeneity: $\mathrm{Ch}^{2}=2.19, \mathrm{df}=4(\mathrm{P}=0.70) ; \mathrm{I}^{2}=0.0 \%$} \\
\hline \multicolumn{7}{|c|}{ Test for overall effect: $Z=0.20(P=0.84)$} \\
\hline \multicolumn{7}{|c|}{ Test for subgroup differences: Not applicable } \\
\hline
\end{tabular}

Analysis 2.8. Comparison 2 IPD data analysis, Outcome 8 Sensitivity analysis removing readmissions in the first 14 days.

Review: Hospital at home early discharge

Comparison: 2 IPD data analysis

Outcome: 8 Sensitivity analysis removing readmissions in the first 14 days

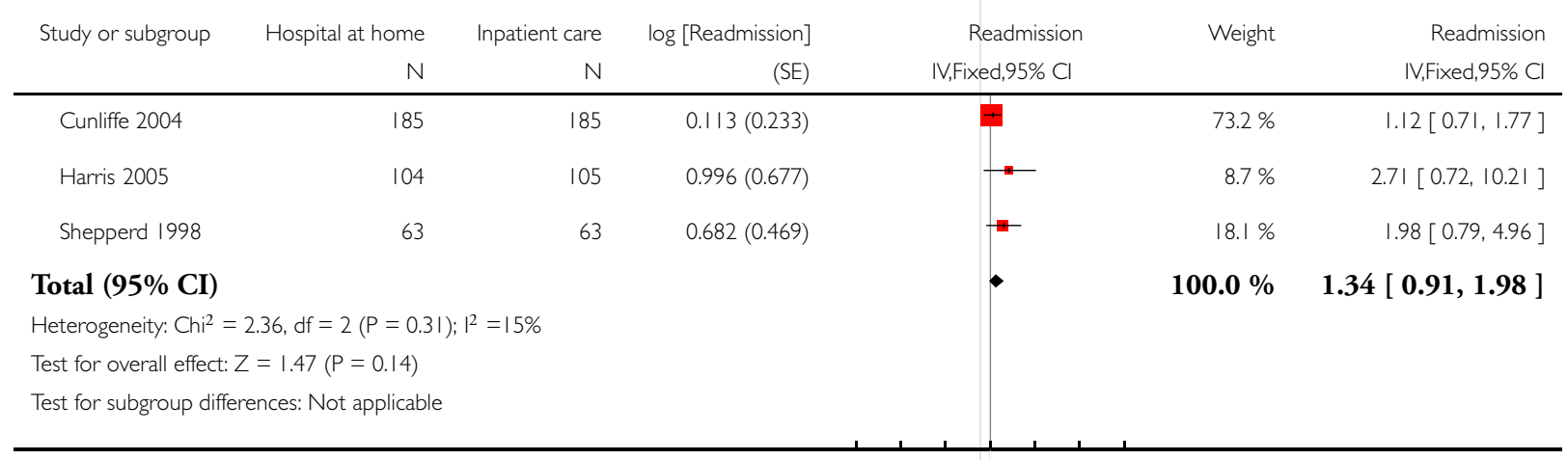

$0.0010 .01 \quad 0.1 \quad 1 \quad 10 \quad 100 \quad 1000$

Favours treatment Favours control 
Analysis 2.9. Comparison 2 IPD data analysis, Outcome 9 Readmission stroke.

Review: Hospital at home early discharge

Comparison: 2 IPD data analysis

Outcome: 9 Readmission stroke

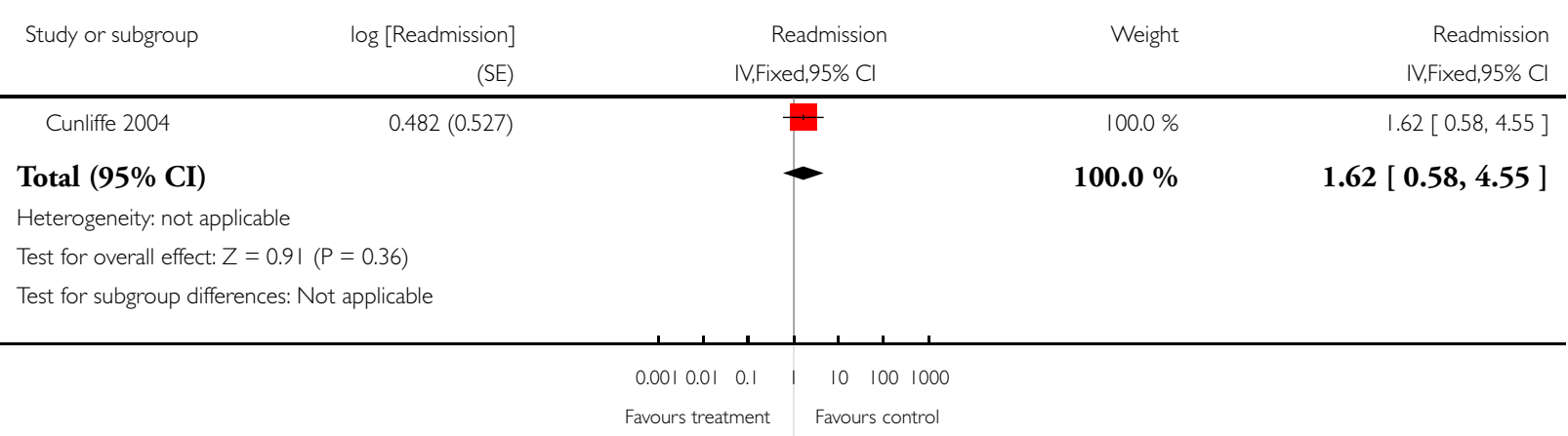

Analysis 3.I. Comparison 3 IPD adjusted for age only, Outcome I IPD generic inverse variance early discharge elderly medical mortality at 3 months.

Review: Hospital at home early discharge

Comparison: 3 IPD adjusted for age only

Outcome: I IPD generic inverse variance early discharge elderly medical mortality at 3 months

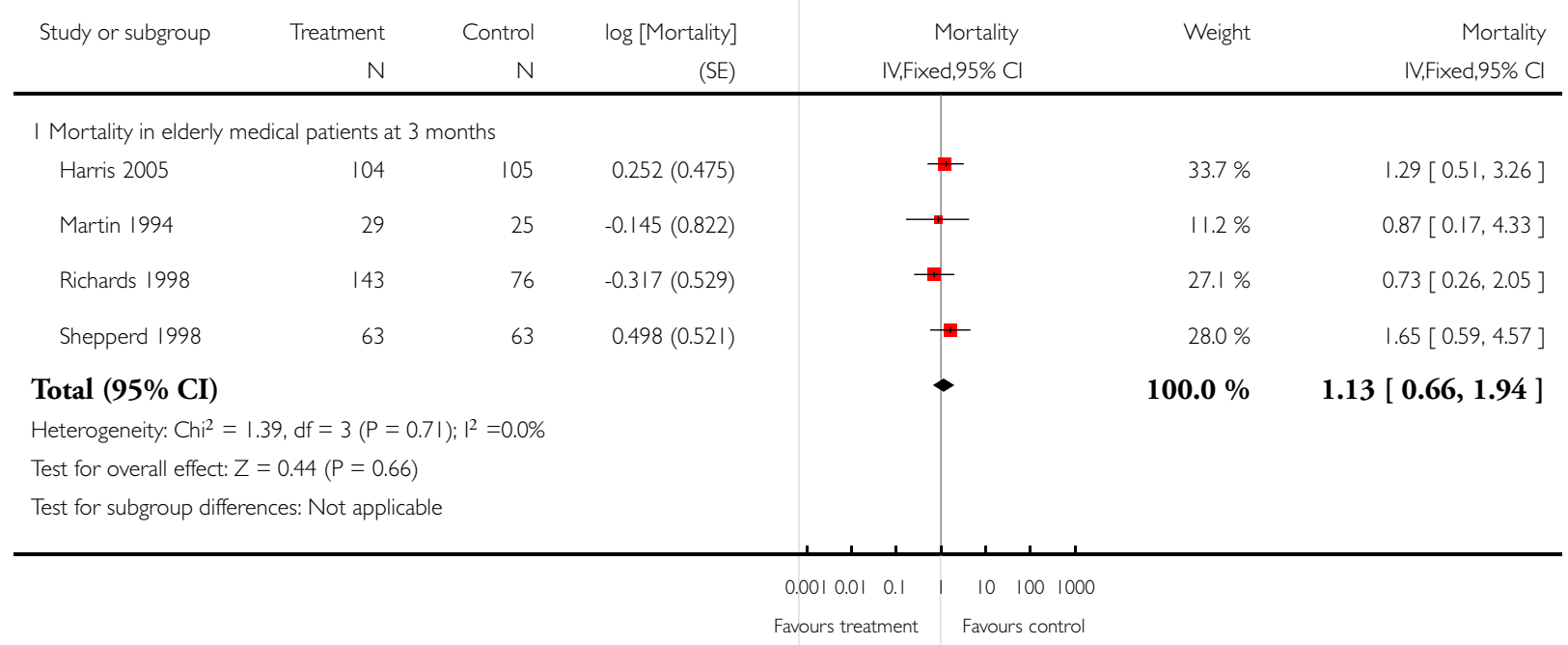


Analysis 3.2. Comparison 3 IPD adjusted for age only, Outcome 2 IPD mortality at 3 to 6 months (Manchester, Anderson \& Shepperd at 3 months).

Review: Hospital at home early discharge

Comparison: 3 IPD adjusted for age only

Outcome: 2 IPD mortality at 3 to 6 months (Manchester, Anderson \% Shepperd at 3 months)

\begin{tabular}{|c|c|c|c|c|c|c|}
\hline \multirow[t]{2}{*}{ Study or subgroup } & Hospital at home & Inpatient care & $\log [$ Mortality $]$ & Mortality & Weight & Mortality \\
\hline & $\mathrm{N}$ & $\mathrm{N}$ & $(\mathrm{SE})$ & IV,Fixed,95\% Cl & & IV,Fixed,95\% Cl \\
\hline Anderson 2000 & 42 & 44 & $2.0819(1.4276)$ & $\square$ & $11.9 \%$ & $8.02[0.49,131.62]$ \\
\hline Bautz-Holter 2002 & 42 & 40 & $-0.693(0.869)$ & $\longrightarrow$ & $32.0 \%$ & $0.50[0.09,2.75]$ \\
\hline Donnelly 2004 & 59 & 53 & $-0.787(1.226)$ & $\longrightarrow$ & $16.1 \%$ & $0.46[0.04,5.03]$ \\
\hline Manchester FASTER & 12 & 11 & $-0.75(1.228)$ & \begin{tabular}{l|l}
$\Psi$ \\
\end{tabular} & $16.0 \%$ & $0.47[0.04,5.24]$ \\
\hline Shepperd 1998 & 11 & 10 & $0.95(1.9949)$ & 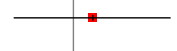 & $6.1 \%$ & $2.59[0.05,129.02]$ \\
\hline Widen-Holmqvist 1998 & 42 & 41 & $-1.15(1.158)$ & $\Psi$ & $18.0 \%$ & $0.32[0.03,3.06]$ \\
\hline \multicolumn{4}{|l|}{ Total $(95 \% \mathrm{CI})$} & - & $100.0 \%$ & $0.69[0.26,1.81]$ \\
\hline \multicolumn{7}{|c|}{ Heterogeneity: Chi $^{2}=4.19, \mathrm{df}=5(P=0.52) ;\left.\right|^{2}=0.0 \%$} \\
\hline \multicolumn{7}{|c|}{ Test for overall effect: $Z=0.75(P=0.45)$} \\
\hline \multicolumn{7}{|c|}{ Test for subgroup differences: Not applicable } \\
\hline
\end{tabular}

$\begin{array}{lllllll}0.001 & 0.01 & 0.1 & 1 & 10 & 100 & 1000\end{array}$

Favours treatment Favours control

Analysis 3.3. Comparison 3 IPD adjusted for age only, Outcome 3 IPD generic inverse variance early discharge readmission at 3 months.

Review: Hospital at home early discharge

Comparison: 3 IPD adjusted for age only

Outcome: 3 IPD generic inverse variance early discharge readmission at 3 months

\begin{tabular}{|c|c|c|c|c|c|c|}
\hline \multirow[t]{2}{*}{ Study or subgroup } & Hospital at home & Inpatient care & $\log$ [Readmission] & Readmission & Weight & Readmission \\
\hline & $\mathrm{N}$ & $N$ & $(\mathrm{SE})$ & IV,Fixed,95\% Cl & & IV,Fixed,95\% Cl \\
\hline Harris 2005 & 104 & 105 & $1.023(0.677)$ & 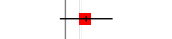 & $24.8 \%$ & $2.78[0.74,10.48]$ \\
\hline Shepperd 1998 & 63 & 63 & $0.863(0.389)$ & +7 & $75.2 \%$ & $2.37[1.11,5.08]$ \\
\hline
\end{tabular}

Total (95\% CI)

$100.0 \% \quad 2.47[1.27,4.78]$

Heterogeneity: $\mathrm{Chi}^{2}=0.04, \mathrm{df}=\mathrm{I}(\mathrm{P}=0.84) ; \mathrm{I}^{2}=0.0 \%$

Test for overall effect: $Z=2.68(P=0.0074)$

Test for subgroup differences: Not applicable 
Analysis 3.4. Comparison 3 IPD adjusted for age only, Outcome 4 Stroke Barthel at 3 months.

Review: Hospital at home early discharge

Comparison: 3 IPD adjusted for age only

Outcome: 4 Stroke Barthel at 3 months

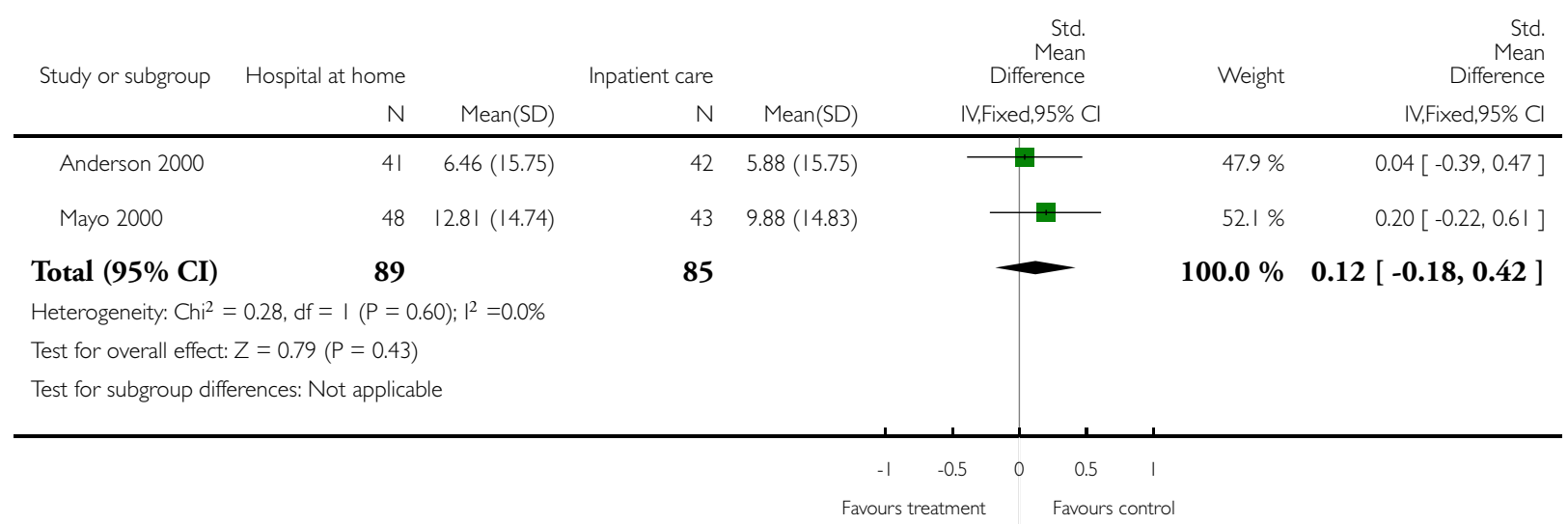

Analysis 3.5. Comparison 3 IPD adjusted for age only, Outcome 5 Stroke Barthel at 6 monhts.

Review: Hospital at home early discharge

Comparison: 3 IPD adjusted for age only

Outcome: 5 Stroke Barthel at 6 monhts

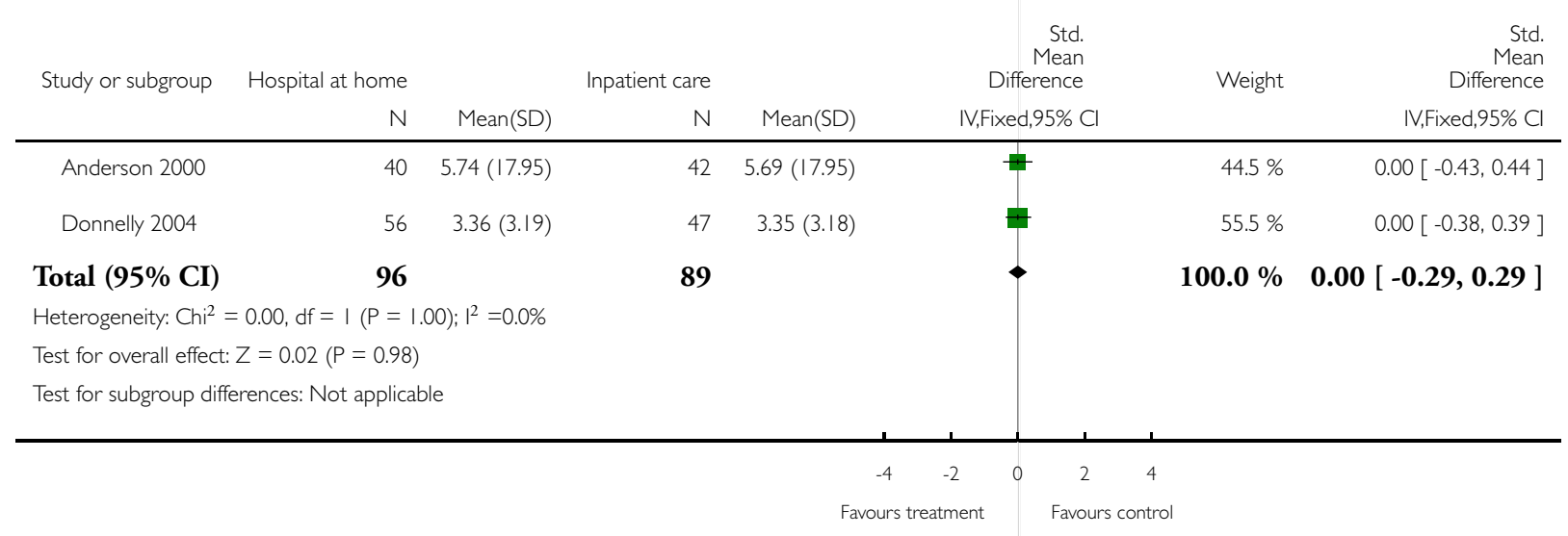


Analysis 3.6. Comparison 3 IPD adjusted for age only, Outcome 6 Sensitivity analysis mortality in favour of HAH.

Review: Hospital at home early discharge

Comparison: 3 IPD adjusted for age only

Outcome: 6 Sensitivity analysis mortality in favour of $\mathrm{HAH}$

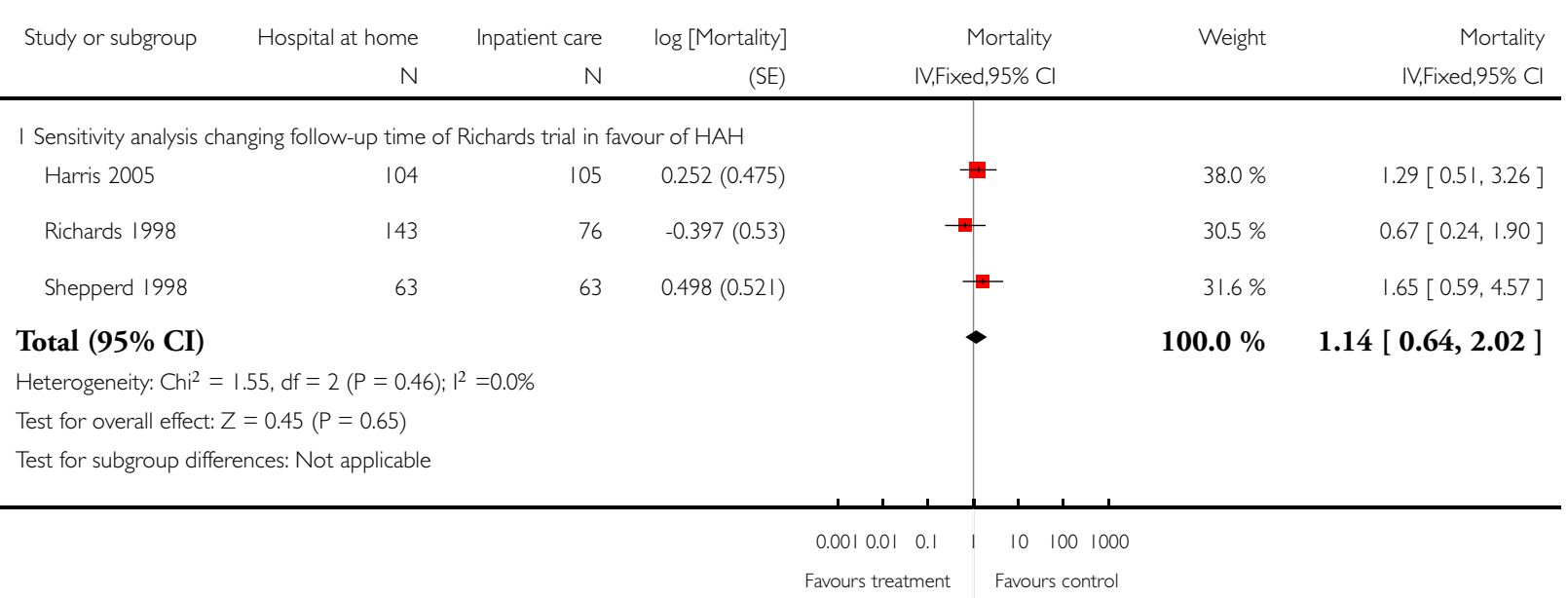

Analysis 3.7. Comparison 3 IPD adjusted for age only, Outcome 7 Sensitivity analysis mortality in favour of hospital.

Review: Hospital at home early discharge

Comparison: 3 IPD adjusted for age only

Outcome: 7 Sensitivity analysis mortality in favour of hospital

\begin{tabular}{|c|c|c|c|c|c|c|}
\hline \multirow[t]{2}{*}{ Study or subgroup } & Treatment & Control & $\log [$ Mortality] & Mortality & \multirow[t]{2}{*}{ Weight } & \multirow{2}{*}{$\begin{array}{r}\text { Mortality } \\
\text { IV,Fixed,95\% Cl }\end{array}$} \\
\hline & $\mathrm{N}$ & $\mathrm{N}$ & $(\mathrm{SE})$ & IV,Fixed,95\% Cl & & \\
\hline \multicolumn{7}{|c|}{ I Sensitivity analysis changing follow-up time of Richards trial in favour of hospital } \\
\hline Harris 2005 & 104 & 105 & $0.252(0.475)$ & 廿 & $37.9 \%$ & $1.29[0.51,3.26]$ \\
\hline Richards 1998 & 143 & 76 & $-0.292(0.529)$ & + & $30.6 \%$ & $0.75[0.26,2.11]$ \\
\hline Shepperd 1998 & 63 & 63 & $0.498(0.521)$ & 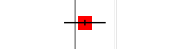 & $31.5 \%$ & $1.65[0.59,4.57]$ \\
\hline Total (95\% CI) & & & & $\rightarrow$ & $100.0 \%$ & $1.18[0.66,2.09]$ \\
\hline \multicolumn{7}{|c|}{ Heterogeneity: Chi $^{2}=1.19, d f=2(P=0.55) ;\left.\right|^{2}=0.0 \%$} \\
\hline \multicolumn{7}{|c|}{ Test for overall effect: $Z=0.56(P=0.58)$} \\
\hline Test for subgroup dif & es: Not appli & & & & & \\
\hline
\end{tabular}

$0.0010 .01 \quad 0.1 \quad 1 \quad 10 \quad 100 \quad 1000$

Favours treatment Favours control 
Analysis 4.I. Comparison 4 IPD adjusted for age and sex, Outcome I IPD generic inverse variance early discharge elderly medical mortality at 3 months.

Review: Hospital at home early discharge

Comparison: 4 IPD adjusted for age and sex

Outcome: I IPD generic inverse variance early discharge elderly medical mortality at 3 months

\begin{tabular}{|c|c|c|c|c|c|c|}
\hline \multirow[t]{2}{*}{ Study or subgroup } & Hospital at home & Inpatient care & $\log [$ Mortality] & Mortality & \multirow[t]{2}{*}{ Weight } & \multirow{2}{*}{$\begin{array}{r}\text { Mortality } \\
\text { IV,Fixed,95\% C }\end{array}$} \\
\hline & $\mathrm{N}$ & $N$ & (SE) & IV,Fixed,95\% Cl & & \\
\hline \multicolumn{7}{|c|}{ I Mortality in elderly medical patients at 3 months } \\
\hline Cunliffe 2004 & 185 & 185 & $-0.09(0.344)$ & & $39.3 \%$ & $0.91[0.47,1.79]$ \\
\hline Harris 2005 & 104 & 105 & $0.262(0.477)$ & & $20.5 \%$ & $1.30[0.51,3.31]$ \\
\hline Martin 1994 & 29 & 25 & $-0.137(0.817)$ & $\square$ & $7.0 \%$ & $0.87[0.18,4.32]$ \\
\hline Richards 1998 & 143 & 76 & $-0.337(0.528)$ & $\rightarrow$ & $16.7 \%$ & $0.71[0.25,2.01]$ \\
\hline Shepperd 1998 & 63 & 63 & $0.622(0.53)$ & 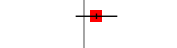 & $16.6 \%$ & $1.86[0.66,5.26]$ \\
\hline Total $(95 \%$ CI $)$ & & & & $\rightarrow$ & $100.0 \%$ & $1.06[0.69,1.61]$ \\
\hline \multicolumn{7}{|c|}{ Heterogeneity: $\mathrm{Chi}^{2}=2.12, \mathrm{df}=4(P=0.7 \mathrm{I}) ; \mathrm{I}^{2}=0.0 \%$} \\
\hline \multicolumn{7}{|c|}{ Test for overall effect: $Z=0.26(P=0.80)$} \\
\hline Test for subgroup dif & ences: Not applicable & & & & & \\
\hline
\end{tabular}

$0.0010 .010 .1 \quad 1 \quad 10 \quad 1001000$

Favours treatment Favours control 
Analysis 4.2. Comparison 4 IPD adjusted for age and sex, Outcome 2 IPD stroke mortality at 3 to 6 months - Manchester, Anderson, Cunliffe \& Shepperd 3 months.

Review: Hospital at home early discharge

Comparison: 4 IPD adjusted for age and sex

Outcome: 2 IPD stroke mortality at 3 to 6 months - Manchester, Anderson, Cunliffe \% Shepperd 3 months

\begin{tabular}{|c|c|c|c|c|c|c|}
\hline \multirow[t]{2}{*}{ Study or subgroup } & Hospital at home & Inpatient care & $\log [$ Mortality] & Mortality & Weight & Mortality \\
\hline & $N$ & $N$ & (SE) & IV,Fixed,95\% Cl & & IV,Fixed,95\% Cl \\
\hline Anderson 2000 & 42 & 44 & $2.0819(1.4276)$ & 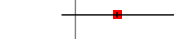 & $10.1 \%$ & $8.02[0.49,131.62]$ \\
\hline Bautz-Holter 2002 & 42 & 40 & $-1.02(0.867)$ & $\longrightarrow$ & $27.3 \%$ & $0.36[0.07,1.97]$ \\
\hline Cunliffe 2004 & 43 & 44 & $1.075(1.171)$ & $\square$ & $15.0 \%$ & $2.93[0.30,29.08]$ \\
\hline Donnelly 2004 & 59 & 53 & $-0.797(1.226)$ & $\longrightarrow$ & $13.7 \%$ & $0.45[0.04,4.98]$ \\
\hline Manchester FASTER & 12 & 11 & $-0.712(1.228)$ & & $13.6 \%$ & $0.49[0.04,5.45]$ \\
\hline Shepperd 1998 & 11 & 10 & $0.95(1.9949)$ & 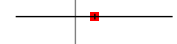 & $5.2 \%$ & $2.59[0.05,129.02]$ \\
\hline Widen-Holmqvist 1998 & 42 & 41 & $-1.155(1.16)$ & $\because$ & $15.3 \%$ & $0.32[0.03,3.06]$ \\
\hline \multicolumn{4}{|l|}{ Total (95\% CI) } & 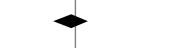 & $100.0 \%$ & $0.79[0.32,1.91]$ \\
\hline \multicolumn{7}{|c|}{ Heterogeneity: $\mathrm{Chi}^{2}=6.05, \mathrm{df}=6(\mathrm{P}=0.42) ; \mathrm{I}^{2}=1 \%$} \\
\hline \multicolumn{7}{|c|}{ Test for overall effect: $Z=0.53(P=0.60)$} \\
\hline \multicolumn{7}{|c|}{ Test for subgroup differences: Not applicable } \\
\hline
\end{tabular}

$0.0010 .01 \quad 0.1 \quad 1 \quad 10 \quad 100 \quad 1000$

Favours treatment Favours control

Analysis 4.3. Comparison 4 IPD adjusted for age and sex, Outcome 3 IPD generic inverse variance readmission elderly patients with a mix of conditions.

Review: Hospital at home early discharge

Comparison: 4 IPD adjusted for age and sex

Outcome: 3 IPD generic inverse variance readmission elderly patients with a mix of conditions

\begin{tabular}{|c|c|c|c|c|c|c|}
\hline Study or subgroup & $\begin{array}{r}\text { Hospital at home } \\
N\end{array}$ & $\begin{array}{r}\text { Inpatient care } \\
\mathrm{N}\end{array}$ & $\begin{array}{r}\log [\text { Readmission }] \\
\text { (SE) }\end{array}$ & $\begin{array}{l}\text { Readmission } \\
\text { IV,Fixed,95\% Cl }\end{array}$ & Weight & $\begin{array}{r}\text { Readmission } \\
\text { IV,Fixed,95\% Cl }\end{array}$ \\
\hline Cunliffe 2004 & 185 & 185 & $0.219(0.214)$ & + & $72.0 \%$ & $1.24[0.82,1.89]$ \\
\hline Harris 2005 & 104 & 105 & $1.016(0.678)$ & $\longrightarrow$ & $7.2 \%$ & $2.76[0.73,10.43]$ \\
\hline Shepperd 1998 & 63 & 63 & $1.058(0.398)$ & $\mp$ & $20.8 \%$ & $2.88[1.32,6.28]$ \\
\hline Total (95\% CI) & & & & $\bullet$ & $100.0 \%$ & $1.57[1.10,2.24]$ \\
\hline \multicolumn{7}{|c|}{ Heterogeneity: $\mathrm{Chi}^{2}=4.20, \mathrm{df}=2(\mathrm{P}=0.12) ; \mathrm{I}^{2}=52 \%$} \\
\hline \multicolumn{7}{|c|}{ Test for overall effect: $Z=2.48(P=0.013)$} \\
\hline Test for subgroup diffe & ences: Not applicable & & & & & \\
\hline
\end{tabular}

$0.0010 .01 \quad 0.1 \quad 1 \quad 10 \quad 100 \quad 1000$

Favours treatment Favours control

Copyright (C) 20II The Cochrane Collaboration. Published by John Wiley \& Sons, Ltd. 


\section{Analysis 4.4. Comparison 4 IPD adjusted for age and sex, Outcome 4 Stroke Barthel at 3 months.}

Review: Hospital at home early discharge

Comparison: 4 IPD adjusted for age and sex

Outcome: 4 Stroke Barthel at 3 months

\begin{tabular}{|c|c|c|c|c|c|c|c|}
\hline \multirow[t]{2}{*}{ Study or subgroup } & \multirow{2}{*}{$\begin{array}{r}\text { Hospital at home } \\
\text { N }\end{array}$} & \multicolumn{3}{|c|}{ Inpatient care } & \multirow{2}{*}{$\begin{array}{r}\text { Std. } \\
\text { Mean } \\
\text { Difference } \\
\text { IV,Fixed,95\% Cl }\end{array}$} & \multirow[t]{2}{*}{ Weight } & \multirow{2}{*}{$\begin{array}{r}\text { Std. } \\
\text { Mean } \\
\text { Difference } \\
\text { IV,Fixed,95\% Cl }\end{array}$} \\
\hline & & Mean(SD) & $\mathrm{N}$ & Mean(SD) & & & \\
\hline Anderson 2000 & 41 & $6.66(16.2)$ & 42 & $5.92(15.88)$ & & $47.9 \%$ & $0.05[-0.38,0.48]$ \\
\hline Mayo 2000 & 48 & $13.64(2.13)$ & 43 & $11.29(15.29)$ & +1 & $52.1 \%$ & $0.22[-0.19,0.63]$ \\
\hline Total $(95 \% \mathrm{CI})$ & 89 & & 85 & & & $100.0 \%$ & $0.14[-0.16,0.43]$ \\
\hline \multicolumn{8}{|c|}{ Heterogeneity: Chi $^{2}=0.33, d f=|(P=0.57) ;|^{2}=0.0 \%$} \\
\hline \multicolumn{8}{|c|}{ Test for overall effect: $Z=0.90(P=0.37)$} \\
\hline \multicolumn{8}{|c|}{ Test for subgroup differences: Not applicable } \\
\hline & & & & & 0.5 & । & \\
\hline
\end{tabular}

Analysis 4.5. Comparison 4 IPD adjusted for age and sex, Outcome 5 Stroke Barthel at 6 months.

Review: Hospital at home early discharge

Comparison: 4 IPD adjusted for age and sex

Outcome: 5 Stroke Barthel at 6 months

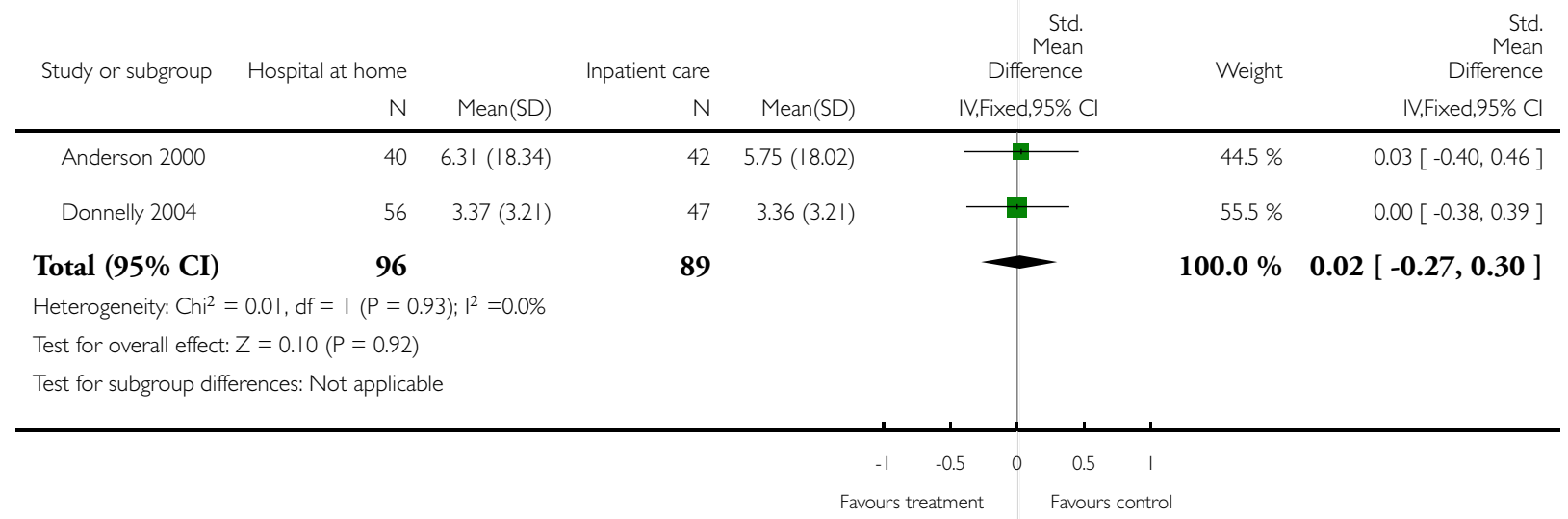


Analysis 4.6. Comparison 4 IPD adjusted for age and sex, Outcome 6 Sensitivity analysis mortality elderly patients with a mix of conditions in favour of $\mathrm{HAH}$.

Review: Hospital at home early discharge

Comparison: 4 IPD adjusted for age and sex

Outcome: 6 Sensitivity analysis mortality elderly patients with a mix of conditions in favour of $\mathrm{HAH}$

\begin{tabular}{|c|c|c|c|c|c|c|}
\hline \multirow[t]{2}{*}{ Study or subgroup } & Hospital at home & Inpatient care & $\log [$ Mortality] & \multirow{2}{*}{$\begin{array}{r}\text { Mortality } \\
\text { IV,Fixed,95\% Cl }\end{array}$} & \multirow[t]{2}{*}{ Weight } & \multirow{2}{*}{$\begin{array}{r}\text { Mortality } \\
\text { IV,Fixed,95\% C }\end{array}$} \\
\hline & $\mathrm{N}$ & $\mathrm{N}$ & (SE) & & & \\
\hline \multicolumn{7}{|c|}{ I Sensitivity analysis changing follow-up time of Richards trial in favour of $\mathrm{HAH}$} \\
\hline Cunliffe 2004 & 185 & 185 & $-0.13(0.344)$ & & $39.3 \%$ & $0.88[0.45,1.72]$ \\
\hline Harris 2005 & 104 & 105 & $0.262(0.477)$ & & $20.5 \%$ & $1.30[0.51,3.31]$ \\
\hline Martin 1994 & 29 & 25 & $-0.21(0.817)$ & $\longrightarrow$ & $7.0 \%$ & $0.81[0.16,4.02]$ \\
\hline Richards 1998 & 143 & 76 & $-0.435(0.529)$ & $\rightarrow$ & $16.6 \%$ & $0.65[0.23,1.83]$ \\
\hline Shepperd 1998 & 63 & 63 & $0.622(0.53)$ & 世- & $16.6 \%$ & $1.86[0.66,5.26]$ \\
\hline Total (95\% CI) & & & & $>$ & $100.0 \%$ & $1.02[0.67,1.55]$ \\
\hline \multicolumn{7}{|c|}{ Heterogeneity: $\mathrm{Chi}^{2}=2.56, \mathrm{df}=4(\mathrm{P}=0.63) ; \mathrm{I}^{2}=0.0 \%$} \\
\hline \multicolumn{7}{|c|}{ Test for overall effect: $Z=0.09(P=0.93)$} \\
\hline Test for subgroup dif & ences: Not applicable & & & & & \\
\hline
\end{tabular}

$0.0010 .01 \quad 0.1 \quad 1 \quad 10 \quad 100 \quad 1000$

Favours treatment Favours control 
Analysis 4.7. Comparison 4 IPD adjusted for age and sex, Outcome 7 Sensitivity analysis mortality elderly patient with a mix of conditions in favour of hospital.

Review: Hospital at home early discharge

Comparison: 4 IPD adjusted for age and sex

Outcome: 7 Sensitivity analysis mortality elderly patient with a mix of conditions in favour of hospital

\begin{tabular}{|c|c|c|c|c|c|c|}
\hline \multirow[t]{2}{*}{ Study or subgroup } & Hospital at home & Inpatient care & $\log [$ Mortality] & \multirow{2}{*}{$\begin{array}{r}\text { Mortality } \\
\text { IV,Fixed,95\% Cl }\end{array}$} & \multirow[t]{2}{*}{ Weight } & \multirow{2}{*}{$\begin{array}{r}\text { Mortality } \\
\text { IV,Fixed,95\% C }\end{array}$} \\
\hline & N & $\mathrm{N}$ & (SE) & & & \\
\hline \multicolumn{7}{|c|}{ I Sensitivity analysis changing follow-up time of Richards trial in favour of hospital } \\
\hline Cunliffe 2004 & 185 & 185 & $-0.13(0.344)$ & \# & $39.3 \%$ & $0.88[0.45,1.72]$ \\
\hline Harris 2005 & 104 & 105 & $0.262(0.477)$ & ?- & $20.5 \%$ & $1.30[0.51,3.31]$ \\
\hline Martin 1994 & 29 & 25 & $-0.21(0.817)$ & $\longrightarrow$ & $7.0 \%$ & $0.81[0.16,4.02]$ \\
\hline Richards 1998 & 143 & 76 & $-0.306(0.528)$ & $\rightarrow$ & $16.7 \%$ & $0.74[0.26,2.07]$ \\
\hline Shepperd 1998 & 63 & 63 & $0.622(0.53)$ & 世- & $16.6 \%$ & $1.86[0.66,5.26]$ \\
\hline Total (95\% CI) & & & & $\rightarrow$ & $100.0 \%$ & $1.04[0.68,1.59]$ \\
\hline \multicolumn{7}{|c|}{ Heterogeneity: $\mathrm{Ch}^{2}=2.19, \mathrm{df}=4(\mathrm{P}=0.70) ; \mathrm{I}^{2}=0.0 \%$} \\
\hline \multicolumn{7}{|c|}{ Test for overall effect: $Z=0.18(P=0.85)$} \\
\hline Test for subgroup dif & ences: Not applicable & & & & & \\
\hline
\end{tabular}

$0.0010 .010 .1 \quad 1 \quad 10 \quad 100 \quad 1000$

Favours treatment Favours control 
Analysis 4.8. Comparison 4 IPD adjusted for age and sex, Outcome 8 Sensitivity analysis changing follow-up time for Donnelly trial in favour of HAH.

Review: Hospital at home early discharge

Comparison: 4 IPD adjusted for age and sex

Outcome: 8 Sensitivity analysis changing follow-up time for Donnelly trial in favour of $\mathrm{HAH}$

\begin{tabular}{|c|c|c|c|c|c|c|}
\hline \multirow[t]{2}{*}{ Study or subgroup } & Hospital at home & Inpatient care & $\log [$ Mortality] & Mortality & Weight & Mortality \\
\hline & $\mathrm{N}$ & $\mathrm{N}$ & (SE) & IV,Fixed,95\% Cl & & IV,Fixed,95\% Cl \\
\hline Anderson 2000 & 42 & 44 & $2.0819(1.4276)$ & $\longrightarrow$ & $11.8 \%$ & $8.02[0.49,131.62]$ \\
\hline Bautz-Holter 2002 & 42 & 40 & $-1.02(0.867)$ & $\div$ & $32.1 \%$ & $0.36[0.07,1.97]$ \\
\hline Donnelly 2004 & 59 & 53 & $-0.878(1.226)$ & $\longrightarrow-$ & $16.1 \%$ & $0.42[0.04,4.59]$ \\
\hline Manchester FASTER & 12 & 11 & $-0.712(1.228)$ & $\longrightarrow$ & $16.0 \%$ & $0.49[0.04,5.45]$ \\
\hline Shepperd 1998 & 11 & 10 & $0.95(1.9949)$ & $\rightarrow$ & $6.1 \%$ & $2.59[0.05,129.02]$ \\
\hline Widen-Holmqvist 1998 & 42 & 41 & $-1.155(1.16)$ & \begin{tabular}{l|l}
$\mp$ \\
1
\end{tabular} & $17.9 \%$ & $0.32[0.03,3.06]$ \\
\hline \multicolumn{4}{|c|}{ Total $(95 \% \mathrm{CI})$} & - & $100.0 \%$ & $0.62[0.23,1.61]$ \\
\hline \multicolumn{7}{|c|}{ Heterogeneity: Chi $^{2}=4.60, d f=5(P=0.47) ;\left.\right|^{2}=0.0 \%$} \\
\hline \multicolumn{7}{|c|}{ Test for overall effect: $Z=0.99(P=0.32)$} \\
\hline \multicolumn{7}{|c|}{ Test for subgroup differences: Not applicable } \\
\hline
\end{tabular}

$\begin{array}{lllllll}0.001 & 0.01 & 0.1 & 1 & 10 & 100 & 1000\end{array}$

Favours treatment Favours control 


\section{Analysis 4.9. Comparison 4 IPD adjusted for age and sex, Outcome 9 Sensitivity analysis changing follow-up time for Donnelly (stroke) in favour of hospital.}

Review: Hospital at home early discharge

Comparison: 4 IPD adjusted for age and sex

Outcome: 9 Sensitivity analysis changing follow-up time for Donnelly (stroke) in favour of hospital

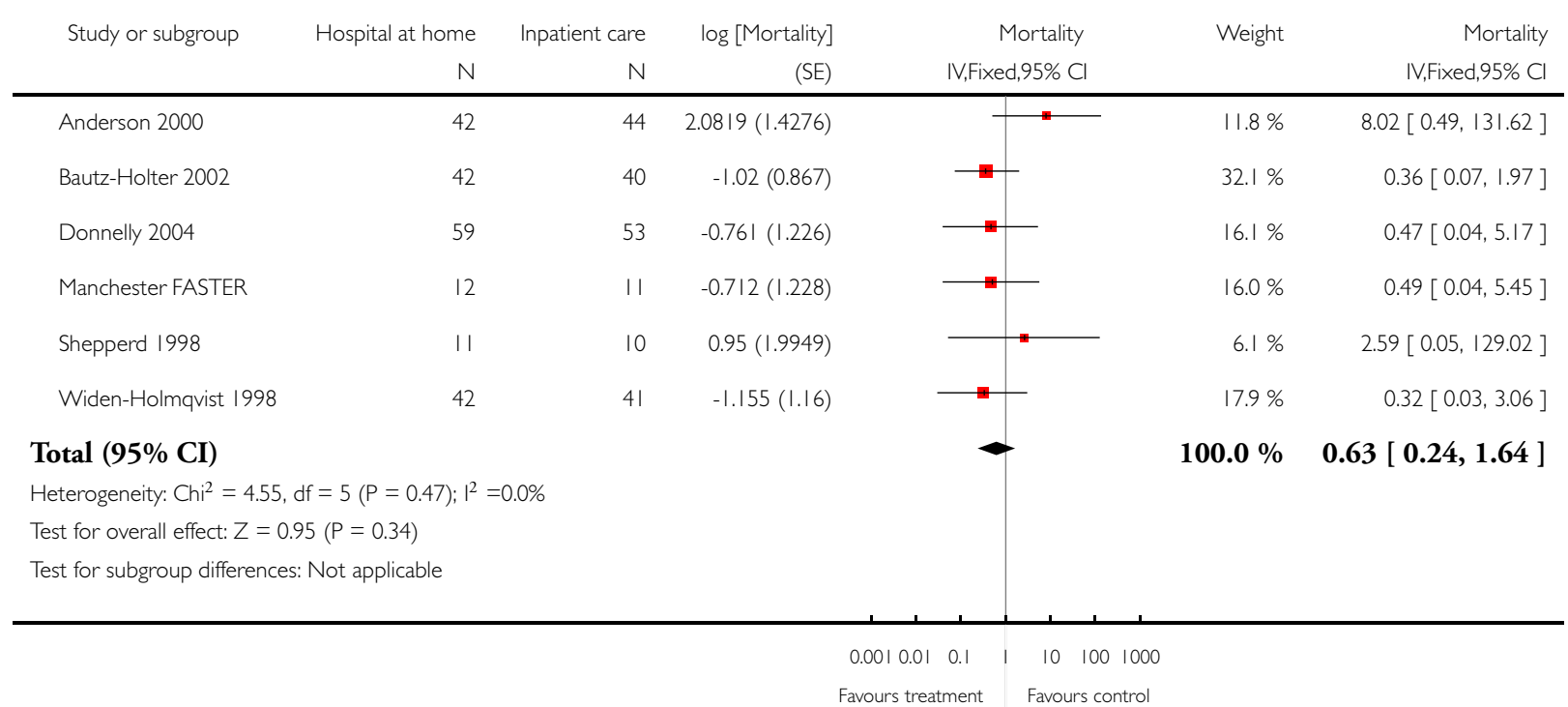

Analysis 4.10. Comparison 4 IPD adjusted for age and sex, Outcome 10 Sensitivity analysis removing readmissions for elderly with a mix of conditions during first 14 days adjusted for age and sex.

Review: Hospital at home early discharge

Comparison: 4 IPD adjusted for age and sex

Outcome: 10 Sensitivity analysis removing readmissions for elderly with a mix of conditions during first 14 days adjusted for age and sex

\begin{tabular}{|c|c|c|c|c|c|c|}
\hline \multirow[t]{2}{*}{ Study or subgroup } & Hospital at home & Inpatient careContro & $\log$ [Readmissions] & Readmissions & Weight & Readmissions \\
\hline & $N$ & $\mathrm{~N}$ & (SE) & IV,Fixed,95\% Cl & & IV,Fixed,95\% Cl \\
\hline Cunliffe 2004 & 185 & 185 & $0.09(0.234)$ & + & $73.9 \%$ & $1.09[0.69,1.73]$ \\
\hline Harris 2005 & 104 & 105 & $0.996(0.677)$ & 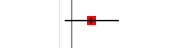 & $8.8 \%$ & $2.71[0.72,10.21]$ \\
\hline Shepperd 1998 & 63 & 63 & $0.722(0.484)$ & 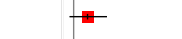 & $17.3 \%$ & $2.06[0.80,5.32]$ \\
\hline
\end{tabular}

Total (95\% CI)

$100.0 \% \quad 1.32[0.89,1.96]$

Heterogeneity: $\mathrm{Chi}^{2}=2.6 \mathrm{I}, \mathrm{df}=2(\mathrm{P}=0.27) ; \mathrm{I}^{2}=23 \%$

Test for overall effect: $Z=1.39(P=0.17)$

Test for subgroup differences: Not applicable 
Analysis 4.I I. Comparison 4 IPD adjusted for age and sex, Outcome I I Readmission - recovering from a stroke.

Review: Hospital at home early discharge

Comparison: 4 IPD adjusted for age and sex

Outcome: II Readmission - recovering from a stroke

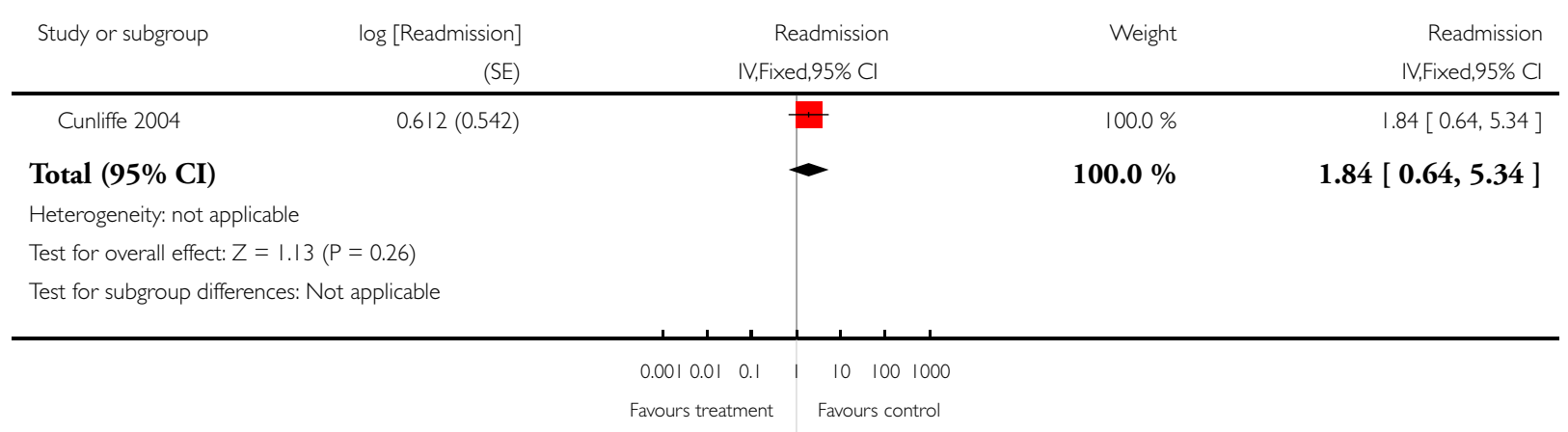

\section{APPENDICES}

\section{Appendix I. Search strategy}

\section{Database: Ovid MEDLINE(R) 1950 to January Week 32008}

1 (hospital adj2 home).tw. (1933)

2 Home-based versus hospital-based.tw. (9)

3 Home hospitalization.tw. (89)

4 or/1-3

5 exp Home Care Services/

6 exp Hospitalization/

75 and 6

84 or 7

9 randomized controlled trial.pt.

10 controlled clinical trial.pt.

11 randomized controlled trials/

12 random allocation/

13 double blind method/

14 single blind method/

15 or/9-14

16 animal/

17 human/

Copyright $(201$ I The Cochrane Collaboration. Published by John Wiley \& Sons, Ltd. 
1816 not (16 and 17)

1915 not 18

208 and 19

21 limit 20 to review

2220 not 21

23 meta-analysis.pt.

2422 not 23

\section{Database: EMBASE 1980 to 2008 Week I I}

1 (hospital adj2 home).tw.

2 Home-based versus hospital-based.tw.

3 Home hospitalization.tw.

4 or/1-3

5 exp Home Care Services/

6 exp Hospitalization/

75 and 6

84 or 7

9 clinical trial/

10 randomization/

11 randomized controlled trial/

12 crossover procedure/

13 double blind procedure/

14 single blind procedure/

15 (randomised or randomized).tw.

16 placebo/

17 (controlled adj study).tw.

18 or/9-17

19 nonhuman/

2018 not 19

218 and 20

Database: CINAHL - Cumulative Index to Nursing and Allied Health Literature 1982 to February Week 52008

1 (hospital adj2 home).tw.

2 Home-based versus hospital-based.tw.

3 Home hospitalization.tw.

4 or/ $1-3$

5 exp Home Care Services/

6 exp Hospitalization/

75 and 6

84 or 7

9 exp clinical trials/

10 clinical trial.pt.

11 (controlled adj (study or trial)).tw.

12 randomized controlled trial/

13 (randomised or randomized).tw.

14 (random\$ adj1 (allocat\$ or assign\$)).tw.

15 or/9-14

168 and 15 


\section{Search methods for EPOC Register 2I January 2008}

home-based and in-patient*

homecare and in-patient*

hospital-at-home and in-patient*

home-based and hospital*

homecare and hospital*

home-care and hospital*

home hospital* and in-patient*

\section{WHAT'S NEW}

Last assessed as up-to-date: 23 July 2008.

\begin{tabular}{lll}
\hline Date & Event & Description \\
\hline 6 July 2011 & Amended & Revised reference to published review \\
\hline
\end{tabular}

\section{H I S T O R Y}

Protocol first published: Issue 3, 1996

Review first published: Issue 1, 1998

\begin{tabular}{lll}
\hline Date & Event & Description \\
\hline 8 June 2011 & Amended & $\begin{array}{l}\text { Title changed for consistency, changes to published } \\
\text { notes }\end{array}$ \\
\hline 17 February 2011 & Amended & Minor changes to published notes \\
\hline 12 November 2008 & New citation required and conclusions have changed & Review has been split from original review. \\
\hline 10 November 2008 & New search has been performed & $\begin{array}{l}\text { This review is an update of Shepperd 2005 but has } \\
\text { been split into three different reviews. }\end{array}$ \\
\hline 28 July 2008 & Amended & Converted to new review format. \\
\hline
\end{tabular}




\section{CONTRIBUTIONS OF AUTHORS}

SS read through abstracts, identified relevant studies, invited trialists to collaborate with the IPD meta-analysis, extracted data from included trials, compiled summary tables of the results and led on writing the review. SS and HD cleaned the data sets for the IPD meta-analysis and analysed the results. SI extracted data from included trials and commented on drafts of the review. PL contacted the Early Supported Discharge trialists recruiting patients recovering from a stroke and obtained permission for the data from these trials to contribute to the IPD meta-analysis. JB prepared and supplied the data for the Harris trial to be used in the IPD meta-analysis. JG, RH, FM and SR supplied trial data. All authors read and had the opportunity to comment on the manuscript.

\section{DECLARATIONS OF INTEREST}

Jo Broad, John Gladman, Roger Harris, Finbarr Martin, Suzanne Richards and Sasha Shepperd were investigators on five of the included trials.

\section{SOURCES OF SUPPORT}

\section{Internal sources}

- Anglia and Oxford NHS Research and Development Programme, UK.

\section{External sources}

- NIHR Research Scientist in Evidence Synthesis Award, UK.

\section{NOTES}

This review is an update; the original review was first published in Issue 1, 1998 of The Cochrane Library (Shepperd 2005). The original review has been separated into three distinct reviews: Hospital at home admission avoidance, Hospital at home early discharge, and Hospital at home: home-based end of life care. The titles have been changed for consistency. Hospital at home admission avoidance (Shepperd 2008) and Hospital at home: home-based end of life care (Shepperd 2011) are published in The Cochrane Library.

\section{INDEX TERMS}

\section{Medical Subject Headings (MeSH)}

${ }^{*}$ Hospitalization [economics]; Home Care Services, Hospital-Based [economics; * standards]; Patient Care [economics; standards]; Patient Discharge; Randomized Controlled Trials as Topic

\section{MeSH check words}

Adult; Humans 